\title{
MONOGRAPH
}

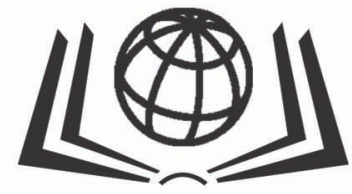

INTERNATIONAL

SCIENCE GROUP

\section{THEORETICAL AND PRACTICAL RESEARCH IN LAW}

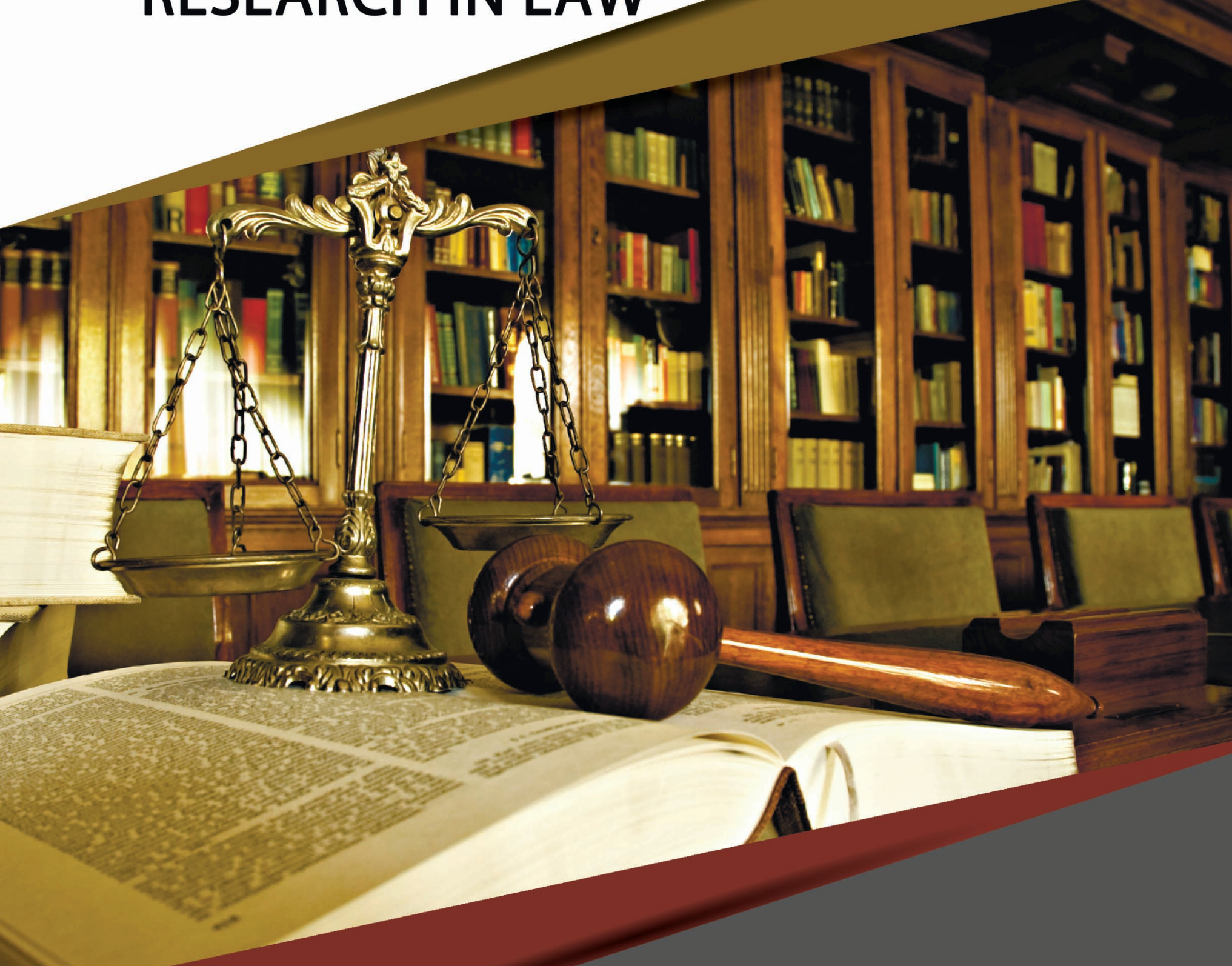

DOI 10.46299/ISG.2021.MONO.LEGAL.II ISBN 978-1-63848-666-4 BOSTON (USA) - 2021 
ISBN - 978-1-63848-666-4

DOI- 10.46299/ISG.2021.MONO.LEGAL.II

Theoretical and practical research in law

Gollective monograph 
Library of Congress Cataloging-in-Publication Data

ISBN - 978-1-63848-666-4

DOI- 10.46299/ISG.2021.MONO.LEGAL.II

Authors - Belkin L., Iurynets J., Sopilko I., Belkin M., Ігнатченко I.Г., Кузьменко Ю.В., Рудниченко С.М., Думанський Р.В., Guyvan P., Kutsevych M.P., Хряпінський П., Школа С., Sivchuk I., Щирська В.C., Oleynik O., Striuk Y., Shmanatova A., Irchyshyna M., Shandra B., Matviienk O., Свищо B., Андрієвська Л., Дзюба I., Тимошевська I., Karpova N., Pestsov R., Karnaukh A., Bilous I., Talianchuk L., Александренко О., Женунтій B., Syroid T., Havrylenko O., Fomina L., Shevchenko А., Пікуля T.

\section{REVIEWER}

Romanova Alona Doctor of Law, Associate Professor, Professor at the Department of Theory and Philosophy of Law, Constitutional and International Law of the Institute of Law, Psychology and Innovative Education of Lviv Polytechnic National University

Published by Primedia eLaunch

https://primediaelaunch.com/

Text Copyright (C) 2021 by the International Science Group(isg-konf.com) and authors. Illustrations (C) 2021 by the International Science Group and authors.

Cover design: International Science Group(isg-konf.com). (C)

Cover art: International Science Group(isg-konf.com). (C)

All rights reserved. Printed in the United States of America. No part of this publication may be reproduced, distributed, or transmitted, in any form or by any means, or stored in a data base or retrieval system, without the prior written permission of the publisher. The content and reliability of the articles are the responsibility of the authors. When using and borrowing materials reference to the publication is required.

Collection of scientific articles published is the scientific and practical publication, which contains scientific articles of students, graduate students, Candidates and Doctors of Sciences, research workers and practitioners from Europe and Ukraine. The articles contain the study, reflecting the processes and changes in the structure of modern science.

The recommended citation for this publication is:

Theoretical and practical research in law: collective monograph / Belkin L., Iurynets J., Sopilko I., Belkin M. - etc. - International Science Group. Boston : Primedia eLaunch, 2021. 220 p. Available at : DOI- 10.46299/ISG.2021.MONO.LEGAL.II 


\section{TABLE OF CONTENTS}

\begin{tabular}{|c|c|c|}
\hline 1. & ADMINISTRATIVE LAW, ADMINISTRATIVE PROCESS & \\
\hline 1.1 & $\begin{array}{l}\text { Belkin L. }{ }^{1} \text {, Iurynets J. }{ }^{1} \text {, Sopilko I. }{ }^{1}, \text { Belkin M. } \\
\text { НАПРАВЛЕНИЯ И УСЛОВИЯ ЛЕГИТИМИЗАЦИИ ИНТЕРНЕТ- } \\
\text { РЕСУРСОВ В УКРАИНЕ КАК СРЕДСТВ МАССОВОЙ } \\
\text { ИНФОРМАЦИИ } \\
{ }^{1} \text { National Aviation University, Kyiv, Ukraine } \\
{ }^{2} \text { Maurice Group Law Firm }\end{array}$ & 7 \\
\hline 1.2 & $\begin{array}{l}\text { Ігнатченко І.Г. }{ }^{1} \\
\text { ТЕОРЕТИЧНІ ПИТАННЯ ПУБЛІЧНОГО АДМІНІСТРУВАННЯ } \\
\text { КУЛЬТУРНО-ІНФОРМАЦЙНОЇ СФЕРИ В УКРАЇРНІ } \\
\text { (ЗАРУБІЖНИЙ ДОСВІД ТА ВІТЧИЗНЯНІ РЕАЛІЇ) } \\
{ }^{1} \text { кафедра адміністративного права } \\
\text { Національний юридичний університет імені Ярослава Мудрого }\end{array}$ & 18 \\
\hline 1.3 & $\begin{array}{l}\text { Кузьменко Ю.В. }{ }^{1} \text {, Рудниченко С.М. }{ }^{1}, \text { Думанський Р.В. }{ }^{1} \\
\text { ПРОБЛЕМА ТОРГІВЛІ ЛЮДЬМИ В УМОВАХ ЗБРОЙНОГО } \\
\text { КОНФЛІКТУ НА ТЕРИТОРІЇ УКРАЇНИ } \\
\text { ' кафедра адміністративного права та адміністративного процесу Херсонського } \\
\text { факультету, Одеський державний університет внутрішніх справ }\end{array}$ & 28 \\
\hline 2. & CIVIL LAW & \\
\hline 2.1 & $\begin{array}{l}\text { Guyvan P. }{ }^{1} \\
\text { STATUTE OF LIMITATION - TIME COORDINATES OF THE } \\
\text { SUBSTANTIVE RIGHT TO CLAIM. } \\
{ }^{1} \text { Poltava Institute of Business, } \\
\text { k. yu. Sciences, Honored Lawyer of Ukraine }\end{array}$ & 34 \\
\hline 3. & IINAL AND CRIMINAL-EXECUTIVE LAW & \\
\hline 3.1 & $\begin{array}{l}\text { Kutsevych М.Р.' } \\
\text { ОКРЕМІ ПИТАННЯ КРИМІНАЛЬНО-ПРАВОВОЇ ОХОРОНИ } \\
\text { ВЛАСНОСТІ ВІД НЕЗАКОННОГО ВИЛУЧЕННЯ З ЖИТЛА, } \\
\text { ПРИМІЩЕННЯ ЧИ ІНШОГО ВОЛОДІННЯ ОСОБИ В ПРАВІ } \\
\text { УКРАЇНИ, ОКРЕМИХ ДЕРЖАВ СС, ВЕЛИКОЇ БРИТАНІЇ ТА } \\
\text { США } \\
{ }^{1} \text { Department of Criminal law politics and Criminal law of the Institute of Law } \\
\text { Taras Shevchenko National University of Kyiv }\end{array}$ & 67 \\
\hline
\end{tabular}




\begin{tabular}{|c|c|c|}
\hline 3.2 & $\begin{array}{l}\text { Хряпінський П. }{ }^{1} \text {, Школа С. }{ }^{1} \\
\text { КРИМІНАЛЬНІ ПОКАРАННЯ ТА ЗАОХОЧЕННЯ ЯК ПАРНІ } \\
\text { ПРАВОВІ КАТЕГОРІЇ: ГНОСЕОЛОГІЧНИЙ АСПЕКТ } \\
\text { 'Department of Public Law of the Institute of Humanities and Social Sciences of the } \\
\text { National Technical University "Dnipro Polytechnic" }\end{array}$ & 80 \\
\hline 4. & CRIMINOLOGY & \\
\hline 4.1 & $\begin{array}{l}\text { Sivchuk I. } \\
\text { СПЕЦИФІКА ПРОВЕДЕННЯ ТОВАРОЗНАВЧОЇ ЕКПЕРТИЗИ В } \\
\text { УКРАЇНІ } \\
\text { 'Economics Ternopil Research Criminal Expertise Center of the Ministry of Internal } \\
\text { Affairs of Ukraine, Ternopil, Ukraine }\end{array}$ & 92 \\
\hline 4.2 & $\begin{array}{l}\text { Щирська В.С. }{ }^{1} \\
\text { ЗАГАЛЬНА ХАРАКТЕРИСТИКА ОРГАНІЗОВАНИХ } \\
\text { ЗЛОЧИННИХ ГРУП, ЩО ВЧИНЯЮТЬ КОНТРАБАНДУ } \\
\text { НАРКОТИЧНИХ ЗАСОБІВ У СФЕРІ СУЧАСНИХ ТЕНДЕНЦІЙ } \\
\text { НАРКОБІЗНЕСУ } \\
{ }^{1} \text { кафедра криминального права та криміноголії } \\
\text { факультету підготовки фахівців для органів досудового розслідування } \\
\text { Одеського державного університету внутрішніх справ }\end{array}$ & 100 \\
\hline 5. & PHILOSOPHY & \\
\hline 5.1 & $\begin{array}{l}\text { Oleynik O. }{ }^{1}, \text { Striuk Y. }{ }^{1}, \text { Shmanatova A. }{ }^{1}, \text { Irchyshyna M. }{ }^{1} \\
\text { PECULIARITIES OF AUTHENTIC TRANSLATION OF } \\
\text { INTERNATIONAL REGULATORY LEGAL ACTS IN THE } \\
\text { ASPECT OF DIFFICULTIES OF USING TERMS } \\
{ }^{1} \text { Dnepropetrovsk State University of Internal Affairs, Senior lecturer at Ukrainian studies } \\
\text { and foreign languages }\end{array}$ & 112 \\
\hline 5.2 & $\begin{array}{l}\text { Shandra B. }{ }^{1} \text {, Matviienk O. }{ }^{1} \\
\text { EXISTENTIAL-AXIOLOGICAL DIMENSION OF } \\
\text { DECRIMINALIZATION OF CONSCIOUSNESS AND SOCIETY } \\
{ }^{1} \text { Department of Philosophy of SHEI "Uzhhorod National University" }\end{array}$ & 119 \\
\hline 5.3 & $\begin{array}{l}\text { Свищо В. }{ }^{1} \\
\text { КОЛІЗІЇ РОЗВИТКУ УКРАЇНСЬКОЇ ЛІБЕРАЛЬНОЇ ДУМКИ } \\
\text { ПЕРШОЇ ПОЛОВИНИ ХІХ СТОЛІТТЯ } \\
\text { ' Кафедра філософії, ДВНЗ «Ужгородський національний університет» }\end{array}$ & 130 \\
\hline
\end{tabular}




\begin{tabular}{|c|c|c|}
\hline \multicolumn{3}{|c|}{ 6. THE CIVIL PROCESS } \\
\hline 6.1 & $\begin{array}{l}\text { Андрієвська Л. }{ }^{1}, \text { Дзюба І. }{ }^{1} \\
\text { МІЖНАРОДНО-ПРАВОВІ СТАНДАРТИ ПРОФЕСІЙНОЇ } \\
\text { ДІЯЛЬНОСТІ АДВОКАТА В ЦИВІЛЬНОМУ ПРОЦЕСІ } \\
\text { УКРАЇНИ } \\
\text { ' кафедра цивільно-правових дисциплін Дніпропетровського державного } \\
\text { університету внутрішніх справ }\end{array}$ & 143 \\
\hline 6.2 & $\begin{array}{l}\text { Тимошевська І. } \\
\text { ПОНЯТТЯ ПЕРЕГОВОРІВ У КОНТЕКСТІ } \\
\text { АЛЬТЕРНАТИВНОГО РОЗГЛЯДУ СПОРІВ У ЦИВІЛЬНИХ } \\
\text { СПРАВАХ } \\
{ }^{1} \text { кафедра цивільного процесу } \\
\text { Національний юридичний університет України імені Ярослава Мудрого }\end{array}$ & 148 \\
\hline 7. & THE CRIMINAL PROCESS & \\
\hline 7.1 & $\begin{array}{l}\text { Karpova N. }{ }^{1} \text {, Pestsov R. }{ }^{2} \text {, Karnaukh A. }{ }^{2} \text {, Bilous I. }{ }^{3} \text {, Talianchuk L. }{ }^{3} \\
\text { SPECIAL FEATURES OF THE CRIMINAL PROVISION OF THE } \\
\text { ATTORNEY GENERAL } \\
{ }^{1} \text { Academican Yuriy Bugay International Scientific and Technical University, Kyiv } \\
{ }^{2} \text { National Pedagogical Drahomanov University, Kyiv } \\
{ }^{3} \text { Vinnytsia Institute of Trade and Economics of Kyiv National University of Trade and } \\
\text { Economics, Vinnytsia }\end{array}$ & 154 \\
\hline 7.2 & $\begin{array}{l}\text { Александренко О. }{ }^{1}, \text { Женунтій В. } \\
\text { ДО ПИТАННЯ ПРО МОЖЛИВОСТІ ВИКОРИСТАННЯ } \\
\text { КРИМІНАЛІСТИЧНОГО АНАЛІЗУ В РОЗСЛІДУВАННІ } \\
\text { ЗЛОЧИНІВ (НА ПРИКЛАДІ СЕРІЙНИХ СЕКСУАЛЬНО- } \\
\text { САДИСТСЬКИХ ВБИВСТВ) } \\
{ }^{1} \text { науково-дослідна лабораторія з проблем криміналістичного забезпечення, } \\
\text { Національна академія внутрішніх справ } \\
\text { ² відділ організації наукової діяльності та захисту прав інтелектуальної власності, } \\
\text { Національна академія внутрішніх справ }\end{array}$ & 164 \\
\hline 8 . & Y AND HISTORY OF STATE AND LAW & \\
\hline 8.1 & $\begin{array}{l}\text { Syroid T. }{ }^{1} \text {, Havrylenko O. }{ }^{1}, \text { Fomina L. }{ }^{1}, \text { Shevchenko A. }{ }^{1} \\
\text { LEGAL FRAMEWORK FOR THE OSCE ACTIVITIES IN } \\
\text { ENSURING THE COMPREHENSIVE SECURITY AT THE } \\
\text { EUROPEAN LEVEL } \\
{ }^{1} \text { Department of International and European Law, Faculty of Law, V.N. Karazin Kharkiv } \\
\text { National University (Kharkiv, Ukraine) }\end{array}$ & 171 \\
\hline
\end{tabular}




\begin{tabular}{|c|c|c|}
\hline 8.2 & $\begin{array}{l}\text { Пікуля Т. } \\
\text { ЮРИДИЧНА КЛІНІЧНА ОСВІТА ЯК ЗАСІБ ФОРМУВАННЯ } \\
\text { НОВОЇ МЕТОДОЛОГІЇ НАВЧАННЯ } \\
{ }^{1} \text { кафедра теорії та історії права } \\
\text { ДВНЗ «Київський національний економічний університет імені Вадима Гетьмана» }\end{array}$ & 195 \\
\hline & REFERENCES & 201 \\
\hline
\end{tabular}




\section{SECTION 1. ADMINISTRATIVE LAW, ADMINISTRATIVE PROCESS}

DOI 10.46299/ISG.2021.MONO.LEGAL.II-7-17

\section{1 Направления и условия легитимизации интернет-ресурсов в Украине как средств массовой информации}

В главе предложено и обосновано законодательно ввести «мягкую» регистрацию Интернет-СМИ в Украине, когда их государственная регистрация осуществляется на добровольной основе, однако отсутствие такой регистрации лишает таких незарегистрированных распространителей информации льгот и преференций, присущих зарегистрированным средствам массовой информации (СМИ). Предлагается Законы «Об информационных агентствах» (ст. 35), «О печатных средствах массовой информации (прессе) в Украине» (ст. 42), «О телевидении и радиовещании» (ст. 67) дополнить оговорками, что презумпция достоверности информации распространяется исключительно на ту информацию, которая получена из зарегистрированных интернет-СМИ. Считаем, что это IDOI 10.46299/ISG.2021.MONO.LEGAL.II-7-17ольной регистрации. Предложено регистрацию Интернет-СМИ урегулировать по модели Закона «Об информационных агентствах» (с учетом особенностей, присущих распространению информации в сети Интернет).

Таким образом, целью данного материала является разработка методов «мягкого» правового регулирования Интернет-СМИ в Украние.

При решении поставленной задачи авторы исходят из того, что освоение новых информационно-коммуникационных технологий является основой социально-экономического и научно-технического прогресса - информатизации общества [1]. В частности, в Законе Украины (далее - ЗУ) «Об основных принципах развития информационного общества в Украине на 2007-2015 годы» признано, что одним из главных приоритетов Украины является стремление построить ориентированное на интересы людей, открытое для всех и направленное на развитие информационное общество, в котором каждый мог бы создавать и накапливать информацию и знания, иметь к ним свободный доступ, 
пользоваться и обмениваться ими, чтобы дать возможность каждому человеку в полной мере реализовать свой потенциал, способствуя общественному и личному развитию и повышая качество жизни (по состоянию на 01.11.2020 этот акт считается действующм и не пересматривался [2]). Вместе с тем, развитие информационного общества не только открывает большие возможности, но одновременно порождает серьезные проблемы относительно нормирования деятельности по распространению информации в сети Интернет [3]. Понятно, что в демократическом правовом государстве, где признан приоритет прав и свобод человека и гражданина, любые ограничения наталкиваются на возражения. Например, большинство интернет-СМИ и их профессиональных объединений выступают категорически против обязательной регистрации интернет-СМИ из-за опасений относительно потенциальных угроз свободе слова [4]. Однако не следует забывать, что права и свободы одних заканчиваются там, где они начинают вредить правам и свободам других. Е. Голуб сообщает, что многие эксперты отмечает опасность использования социальных сетей как источника информации, поскольку именно так называемые новые медиа является одним из самых распространенных способов распространения ложной информации и фейков. Отмечается, что в последнее время все чаще классические СМИ пользуются соцсетями как первоисточниками [5]. То есть, рано или поздно проблему урегулирования распространения информации в сети Интернет придется решать.

Согласно статье 34 Конституции Украины, каждому гарантируется право на свободу мысли и слова, на свободное выражение своих взглядов и убеждений. Каждый имеет право свободно собирать, хранить, использовать и распространять информацию устно, письменно либо иным способом - по своему выбору. Осуществление этих прав может быть ограничено законом в интересах национальной безопасности, территориальной целостности или общественного порядка с целью предотвращения беспорядков или преступлений, для охраны здоровья населения, для защиты репутации или прав других лиц, предотвращения разглашения информации, полученной конфиденциально, или 
обеспечения авторитета и беспристрастности правосудия. Эти формулировки отражают дуализм прав и обязанностей в сфере свободы самовыражения, согласно которому (дуализму) указанные права гарантируются, но могуm подлежать определенным ограничениям. Согласно ч. 1 ст. 2 ЗУ «Об информации», основными принципами информационных отношений в Украине, в частности, определены: достоверность и полнота информации; правомерность получения, использования, распространения, хранения и защиты информации; защищенность личности от вмешательства в его личную и семейную жизнь. Общее правило по обращению с информацией изложены в ч. 2 ст. 302 Гражданского кодекса Украины: «Физическое лищу, распространяющее информацию, обязано убедиться в ее достоверности. Физическое лицо, которое распространяет информациюю, полученную из офицчиальных источников (информация органов государственной власти, органов местного самоуправления, отчеты, стенограммы и т.n.), не обязано проверять ее достоверность и не несет ответственности в случае ее опровержения. Физическое лицо, которое распространяет информацию, полученную из офиџиальныхх источников, обязано делать ссылку на такой источник». Итак, информация, исходящая через официальные источники от органов власти, в частности, официальные страницы таких органов в сети Интернет, считается достоверной, и физическое лицо не должно отвечать за последствия распространения такой информации. Во всех других случаях именно на физическое лицо, распространяющее информацию, возлагается ответственность за ее распространение. Это касается даже тех случаев, когда физическое лицо распространяет уже созданную кем-то другим информацию, в том числе средствами сети Интернет [6].

Вместе с тем, согласно ст. 42 ЗУ «О печатных средствах массовой информации (прессе) в Украине», редакция, журналист средства массовой информации не несут ответственности за публикацию сведений, не соответствующих действительности, унижающих честь и достоинство граждан и организаций, нарушающих права и законные интересы граждан или 
представляющих собой злоупотребление свободой деятельности печатных средств массовой информации и правами журналиста, если: 1) эти сведения получены от информационных агентств или от учредителя (соучредителей); 2) они содержатся в ответе на запрос на информацию, поданый в соответствии с ЗУ «О доступе к публичной информации», или в ответе на обращение, поданное в соответствии с ЗУ «Об обращении граждан»; 3) они являются дословным воспроизведением публичных выступлений или сообщений субъектов властных полномочий, физических и юридических лиц; 4) они являются дословным воспроизведением материалов, опубликованных другим печатным средством массовой информации со ссылкой на него; 5) в них разглашается тайна, которая специально охраняется законом, однако эти сведения не были получены журналистом незаконным путем; 6) законом предусмотрено освобождение или непривлечение к ответственности за такие действия.

Согласно ст. 35 3У «Об информационных агентствах», информационное агентство, субъекты деятельности информационных агентств не несут ответственности за распространение информации, которая не соответствует действительности, унижает честь и достоинство граждан и организаций, нарушает их права и законные интересы или представляет собой злоупотребление свободой деятельности информационных агентств и правами журналиста, если эта информация: 1) получена от других информационных агентств или средств массовой информации и является дословным воспроизведением материалов, опубликованных этими агентствами или средствами массовой информации, даже если они были опровергнуты в соответствии со статьей 33 настоящего Закона; 2), 3) - как в соответствующих пунктах ст. 42 ЗУ «О печатных средствах массовой информации (прессе) в Украине»; 4) является результатом внесения изменений, сокращений или редактирования продукции информационных агентств, осуществленных без их ведома распространителем или потребителем информации; 5) законом предусмотрено освобождение или непривлечение к ответственности за такие действия. Таким образом, эти нормы предусматривают расширенный перечень 
оснований для освобождения от ответственности за обнародование непроверенной информации: как по источникам информации, так и по кругу распространителей - не только полученной от официальных лиц субъектов властных полномочий, но и полученной от других СМИ, и не только распространителями - физическими лицами, но и непосредственно СМИ. Назовем эти нормы презумпцией достоверности информации. В условиях распространения практики, когда многие СМИ, в том числе печатные, распространяют (перепечатывают) материалы с интернет-ресурсов, в таких СМИ, в случае претензий к достоверности таких материалов, возникает соблазн ссылаться именно на ст. 35 3У «Об информационных агентствах», ст. 42 3У «О печатных средствах массовой информации (прессе) в Украине», приравнивая материалы, перепечатанные из Интернет-ресурса, к такой, что полученная от СМИ и/или информационных агентств. Так, в решении от 05.05.2011 г. Европейский Суд по правам человека (далее - ЕСПЧ) по делу «Редакция газеты «Правое дело» и Штекель против Украины» рассмотрена ситуация, когда эта газета (главный редактор - Штекель Л.И.) перепечатала из Интернета информационные материалы, которые впоследствии оказались недостоверными. За это газета была привлечена к ответственности. В обращении в ЕСПЧ заявители ссылались на приведенную выше, согласно ст. 42 3У «О печатных средствах массовой информации (прессе) в Украине», презумпцию достоверности информации. Рассмотрев эту ситуацию, ЕСПЧ (по тексту решения - Суд) пришел к следующим выводам (выделено авторами (https://zakon.rada.gov.ua/laws/show/974_807):

«60. Суд отмечает, что указанная публикация была дословным воспроизведением материала, загруженного из общзедоступной Интернетгазетьл. Она содержала ссьлки на источник материала и комментарии редакции, в которых она формально дистанцичровалась от содержания.

61. Украинское законодательство, в частности, Закон Украиньл «О печатных средствах массовой информации (прессе) в Украине» предоставляет журналистам иммунитет от гражданской ответственности за дословное 
воспроизведение материала, опубликованного в прессе. Суд обращцает внимание на то, что это положение в общем плане соответствует его подходу к свободе журналистов распространять высказывания, сделанные другими.

62. Однако в соответствии с позищуией национальных судов, такой иммунитет журналистов не распространяется на воспроизведение материала из Интернет-источников, которые не зарегистрированы 6 соответствии с Законом Украины «О печатных средствах массовой информациии (прессе) в Украине». В связи с этим Суд отмечает, что в то время не существовало национальных нормативных актов по государственной регистрацчии Интернет-изданий...

64. Однако, принимая во внимание роль, которую играет Интернет в контексте профессиональной деятельности средств массовой информации, $и$ его важность для общуего осущуествления права на свободу выражения мнения, Суд считает, что отсутствие на национальном уровне достаточной законодательной базы, которая бы позволяла журналистам использовать полученную из Интернета информациию без боязни нарваться на санкции, серьезно препятствует прессе играть свою роль «сторожевого пса общества». По мнению Суда, полное исключение такой информации из сферы применения законодательных гарантий журналистских свобод может само по себе повлечь неправомерное вмемательство в свободу прессы, гарантированную статьей 10 Конвенциии».

Таким образом, по мнению ЕСПЧ, правовое регулирование Интернетресурсов как СМИ должно быть, и это не только не ограничивает свободы распространения информации, а наоборот, повышает уровень гарантий для пользователей этой информацией. Одновременно повышается и уровень ответственности таких электронных СМИ за нарушение законодательства в сфере СМИ. Вместе с тем, этот вопрос в Украине не решен до сих пор [4], а отсутствие такого регулирования позволяет Интернет-ресурсам, даже тем, которые считают себя респектабельными, полностью игнорировать любые 
правила журналистской и издательской этики [6]. При правовой нерешенности вопроса регистрации Интернет-изданий, «Центр демократии и верховенства права» считает наиболее оптимальным для получения дополнительных гарантий журналистской деятельности для работников таких изданий регистрацию интернет-изданий в качестве информационного агентства, упрощает доступ к признанию работников агентства журналистами [7]. Таким образом, в условиях, когда сторонники свободы слова препятствуют предпринимаемым попыткам введения правового регулирования распространения информации в сети Интернет и считают покушением на эти свободы, предлагается «мягкое» внедрение в Украине правового регулирования СМИ в сети Интернет, когда государственная регистрация Интернет-СМИ осуществляется на добровольных началах, однако отсутствие такой регистрации лишает таких незарегистрированных распространителей информации льгот и преференций, присущих зарегистрированным СМИ. Приведенные в этой статье соображения и предложения воплощены авторами в разработанный ими проект закона «О внесении изменений в некоторые законодательные акты Украины относительно защиты прав граждан и государства в сфере информационных отношений». В частности, предлагается ст. 35 3У «Об информационных агентствах», ст. 42 3У «О печатных средствах массовой информации (прессе) в Украине», ст. 67 ЗУ «О телевидении и радиовещании» дополнить оговорками, что презумпция достоверности информации распространяется исключительно на ту информацию, которая получена из зарегистрированных интернет-СМИ. Считаем, что это повысит интерес к такой добровольной регистрации. Кроме того, считаем, что уровень доверия к распространяемой информации может быть повышен обязательным размещением на главной интернет-странице ИнтернетСМИ выходных данных издания: 1) название издания; 2) учредитель (соучредители) 3) фамилия и инициалы редактора (главного редактора); 4) адрес редакции, издателя, типографии; 5) серия, номер и дата выдачи свидетельства о государственной регистрации; 6) издатель (соиздатели). Одновременно предлагается повысить уровень гарантий для лиц, в отношении которых 
распространяется информация, нарушающая права и интересы таких лиц, а именно: установить, что такие лица имеют право на ответ даже в случае воспроизведения информации из других СМИ. Это поможет уменьшить такие негативные проявления, когда по сговору многих СМИ ведется информационная атака на определенных лиц или учреждения со взаимными ссылками друг на друга. Поскольку на данный момент в Украине сложилась практика регистрации интернет-СМИ по модели информационных агентств [7], предложено регистрацию интернет-СМИ законодательно урегулировать по модели ЗУ «Об информационных агентствах» (с учетом особенностей, присущих распространению информации в сети Интернет).

Необходимо обратить внимание, что неурегулированность данной проблемы создаёт прямые информационные угрозы безопасности государства и общества. Так, Г. Почепцов [8] сообщает, что Глеб Павловский, представленный «Комсомольской правдой» как «ветеран информационных войн», особое внимание уделяет различным Интернет-проектам, рассматривая их как идеальный инструмент для запуска в массовое сознание необходимых сюжетов. Он говорит: «Традиционные средства массовой информации несут ответственность за распространяемые ими сведения. Слухи же, передающиеся через Интернет, - анонимные. Но потом газеты, телевидение получают возможность ссылаться на Интернет. То есть происходит настоящее отмывание так называемой "черной" информации. Ранее с этой «черной» информации можно было сделать только "серую" - распространять ее в кулуарах, не больше. Теперь есть возможность отмывать любую дезинформацию добела».

А. Митенко [9] также отмечает, что отсутствие механизмов государственного контроля за распространением информации через интернетсайты вызывает стремительное увеличение объема сообщений общественнополитического содержания (анонимных, достоверность которых вызывает сомнения, провокационного и откровенно противоправного характера), которые дублируются традиционными отечественными СМИ с ссылкой на Интернет. 
Упомянутый выше Е. Голуб [5] подчеркивает, что когда классические СМИ пользуются соцсетями как первоисточниками, и при этом журналисты из лености или отсутствия опыта не проверяют достоверности информации, эта непроверенная информация попадает на телевидение и распространяется на массовую аудиторию. Неоспоримым является опасность распространения ложной информации в условиях информационной войны, которая является частью гибридной войны, которую Россия ведет против Украины. Это влияет не только на гражданское население Украины, но и демобилизует военных, защищающих свою страну. Все эти технологии давно отработаны. Исследования показывают, что люди считают наиболее важными именно те темы и проблемы, которые активно освещаются и обсуждаются в СМИ. Таким образом можно целенаправленно корректировать представления общества - фактически формировать новую реальность.

По информации сайта StopFake, ложные новости распространяют, прежде всего, российские СМИ. Украинские же СМИ могут тиражировать ложь, если не тщательно проверят источник информации. Именно поэтому журналистам стоит особенно внимательно проверять информацию из социальных сетей, чтобы не стать переносчиками фейков. Именно проверка и обработка полученной информации является одной из обязанностей журналиста. Собственно, тем и должны отличаются традиционные СМИ от социальных сетей и сайтовагрегаторов.

А. Белый [10] провел исследование источников появления фейковых рейтингов Украины по экономической надежности или безопасности проживания. Например, первоначально сайт «Numbeo» обнародовал «сведения» о якобы крайне низком рейтинге и патовой криминогенной ситуации в Украине на фоне всех европейских стран. А отдельные города, такие как Одесса и Днепр, занимают в этом антирейтинге городов 12 и 13 место. «Новость» получила довольно серьезный резонанс в СМИ.

Вместе с тем, исследование показало, что в опубликованном рейтинге отсутствуют источники данных и их верификация. Отсутствуют критерии 
подсчета и количественные показатели. Отмечается, что ни одно серьезное издание не ссылалось на ресурс «Numbeo» в публикациях, связанных с исследованиями в области криминогенной ситуации.

Резонно предположить, отмечает автор исследования, что причиной таких фейковых новостей является искусственное создание представления об инвестиционной непривлекательности Украины, поскольку инвестиции, особенно долгосрочные, в страну с низким уровнем безопасности и стабильности маловероятны. Зато наибольшие риски в Украине, с точки зрения финансовой стабильности, имели место в 2015 г.. В то же время последние 3 года по общепринятым мировым рейтингам Украина имеет положительную тенденцию развития. Так, авторитетные рейтинговые агентства свидетельствуют, что несмотря на продолжающуюся вооруженную агрессию и дестабилизирующее влияние со стороны РФ, связанный с этим нелегальный оборот оружия, пандемии COVID-19 и связанную с ней экономическую рецессию, благодаря усилиям системы МВД и других правоохранительных органов 65 \% населения считает Украину безопасным местом для проживания. Это ненамного хуже показателей Соединенного Королевства (70 \%), Италии и Франции (71 \%), Болгарии (72 \%). В 2017 году в среднем по ЕС в этот показатель составлял 82 \%. Не стоит забывать, указывает автор исследования, ангажированность некоторых СМИ, которіе тиражируют фейковые рейтинги с сомнительными источниками - это один из ключевых факторов ведения против Украины жесткой гибридной войны.

Таким образом, в условиях, когда сторонники свободы противятся попыткам введения правового регулирования распространения информации в сети Интернет и считают это покушением на эти свободы, предлагается «мягкое» внедрение в Украине правового регулирования СМИ в сети Интернет, когда государственная регистрация Интернет-СМИ осуществляется на добровольных началах, однако отсутствие такой регистрации лишает таких незарегистрированных распространителей информации льгот и преференций, присущих зарегистрированным СМИ. 
Изложенное исследование приводит к следующим выводам.

1. ЕСПЧ не считает принятие национальных нормативных актов по государственной регистрации интернет-изданий нарушением свободы слова. При условии надлежащего правового регулирования такая регистрация, наоборот, усиливает гарантии деятельности журналистов и расширяет круг информации, к которой можно применять презумпцию достоверности - при одновременном повышении ответственности таких Интернетраспространителей за распространение ненадлежащей информации.

2. Предложено законодательно ввести «мягкую» регистрацию интернетСМИ, когда государственная регистрация Интернет-СМИ осуществляется на добровольной основе, однако отсутствие такой регистрации лишает таких незарегистрированных распространителей информации льгот и преференций, присущих зарегистрированным СМИ. В частности, предлагается ст. 35 ЗУ «Об информационных агентствах», ст. 42 3У «О печатных средствах массовой информации (прессе) в Украине», ст. 67 ЗУ «О телевидении и радиовещании» дополнить оговорками, что презумпция достоверности информации распространяется исключительно на ту информацию, которая получена из зарегистрированных интернет-СМИ. Считаем, что это повысит интерес к такой добровольной регистрации. Предложено регистрацию интернет-СМИ законодательно урегулировать по модели ЗУ «Об информационных агентствах» (с учетом особенностей, присущих распространению информации в Интернет).

3. Рекомендуется зарегистрированным интернет-СМИ размещать сведения о своей официальной регистрации в качестве информационного агентства на собственном сайте, что повысит уровень доверия к распространяемой ими информации. 
DOI 10.46299/ISG.2021.MONO.LEGAL.II-18-27

\section{2 Теоретичні питання публічного адміністрування культурно- інформаційної сфери в Україні (зарубіжний досвід та вітчизняні реалії)}

Характеризуючи юридичну ситуацію сучасної України у галузях культури та інформації, слід відмітити надзвичайну складність і суперечливість культурноінформаційного простору країни, в якому відбиваються як окремі регіональні особливості і тенденції, обумовлені системою організації і функціонування різних суб’єктів соціально-культурної діяльності на місцях, так і загальнодержавні, такі, що мають загальноукраїнську проблематику. Значна частина останніх сформувалася внаслідок проведення політико-економічних реформ без урахування соціально-культурних аспектів, а також потреб інформаційного життя України. Означена ситуація є визначальною для законодавчого регулювання у відповідній області, розробки пріоритетних напрямків державної культурної (та інформаційної) політики та іï реалізації в процесі діяльності державних органів [11, с. 47]. Це потребує переосмислення доктринальних основ публічного адміністрування та визначення його нових функцій в інформаційно-культурній сфері з метою підвищення якості та ефективності діяльності останнього, а також формування і втілення в життя нової державної політики у цій царині.

Сьогодні перед українською державою, зокрема перед органами державної влади та місцевого самоврядування, стоять пріоритетні і стратегічні завдання, головна мета яких перетворити культуру в дієвий інструмент реалізації політичних і соціально-економічних реформ. Однак реалії свідчать, що стратегічні завдання вітчизняної галузі культури 3 року в рік, на жаль, залишаються формальними $\mathrm{i}$ не виконуються через низку невирішених проблемних питань і різного роду факторів [12, с. 50].

Динамічний процес глобалізації у світі диктує підвищені вимоги до якості публічного адміністрування, пріоритетними напрямками якого повинні стати: (1) пошук ефективних засобів і методів регулювання інформаційної та культурної сфер суспільства; (2) формування єдиного культурно-інформаційного простору; (3) створення позитивного іміджу органів державної влади та управління й підвищення довіри суспільства до публічної влади; (4) встановлення 
конструктивного діалогу між державою і громадянським суспільством для вирішення соціально значущих проблем, захист інтересів суспільства, особистості, держави тощо. Тому публічне адміністрування та державна культурна та інформаційна політика в умовах сучасного суспільства повинні здійснювати ряд найважливіших соціальних функцій: інтеграційну освітню, поширювальну, охоронну, власне культурну, інформаційну тощо.

До того ж курс на розвиток економіки «знань та вмінь» й євроінтеграцію, яким рухається Україна сьогодні, вимагає враховувати світові тенденції інформаційного суспільства, які спонукають до впровадження якісно нової моделі фінансування та адміністрування культурно-інформаційної галузі з урахуванням потреб суспільства.

Проблемами культурної та інформаційної політики, а також питаннями міжвідомчої координації у свій час займалися такі російські та українські автори, як В. П. Андрущенко, І. В. Арістова, Ю. П. Богуцький, І. Д. Безгін, А. Гриценко, І. М. Дзюба, М. Г. Жулинський, В.В. Зуй, В. В. Карлова, Б.А. Кормич, В. Г. Кремень, В. І. Малімон, А.В. Мерзляк, П. І. Надолішній, В. А. Скуратівський, С.А. Чукут, Ю.В. Якимець а також західноєвропейські та американські вчені, зокрема Д. Адамс, В. Болто, А. Голдбард, Е. Еверітт, Ч. Лендрі, К. Мак-Кохи, С. Манді, Ф. Матарассо, Г. Хілдман-Чартран та інші.

Незважаючи на значну кількість досліджень слід констатувати, що нині в науці адміністративного права відсутні дослідження, в яких здійснювався б аналіз різних аспектів нової доктрини публічного адміністрування у культурноінформаційній сфері в Україні, зокрема, у зв’язку 3 пошуками сучасної міжгалузевої моделі публічного управління та модернізації механізмів державної підтримки галузей культури та інформації.

Тому зосередимося на аналізі двох важливих теоретичних питань публічного адміністрування в інформаційно-культурній сфері України на сучасному етапі 3 урахуванням зарубіжного досвіду та формулювання шляхів їх практичного втілення за допомогою адміністративно-правових заходів, а саме: 1) переосмислення суспільної ролі Міністерства культури та інформаційної політики 
України (далі - МКІП) в умовах реформ; (2) модернізації системи фінансування галузі з урахуванням зарубіжного досвіду. Їх слід розглядати як засади нової доктрини публічного адміністрування в інформаційно-культурній галузі поряд із: становленням економіки креативних індустрій, формуванням сучасної інформаційної політики та забезпеченням інформаційної безпеки, новою політикою надання адміністративних й інформаційно-культурних послуг, а також запровадженням інноваційних форм і методів цього адміністрування.

Отже, на сучасному етапі в Україні виникла потреба у новому баченні перспектив розвитку останнього, визначення системи суб'єктів публічного управління та шляхів удосконалення адміністративно-правового механізму розподілу повноважень між органами публічної адміністрації у зазначеній сфері.

Наразі центральним органом виконавчої влади у сфері культури та інформаційної політики є МКІП. Це Міністерство забезпечує формування та реалізує державну політику у сферах культури, державної мовної політики, популяризації України у світі, державного іномовлення, інформаційного суверенітету України (у частині повноважень з управління цілісним майновим комплексом Українського національного інформаційного агентства «Укрінформ») та інформаційної безпеки, а також забезпечує формування та реалізацію державної політики у сферах кінематографії, відновлення та збереження національної пам'яті, міжнаціональних відносин, релігії та захисту прав національних меншин в Україні, мистецтв, охорони культурної спадщини, музейної справи, вивезення, ввезення і повернення культурних цінностей

МКІП є головним органом у системі центральних органів виконавчої влади, що забезпечує формування та реалізацію державної політики у сфері телебачення і радіомовлення, інформаційній та видавничій сфері, у сфері туризму та курортів (крім здійснення державного нагляду (контролю) у сфері туризму та курортів) [13].

Така модель Міністерства сформувалася поступово й пройшла ряд кроків свого становлення за роки незалежності. Так, до 1995 р. міністерство носило назву «Міністерство культури». Потім до 2005 р. - «Міністерство культури і мистецтв». 
Після реформи і реорганізації 2005 р., міністерство отримало назву «Міністерства культури і туризму». Втім у 2010 р. йому було повернуто назву «Міністерство культури України». 29 08. 2019 р. відбулася чергова реорганізація Міністерства інформаційної політики України в Міністерство культури, молоді та спорту України з приєднанням Міністерства культури України та Міністерства молоді та спорту України й, нарешті, 23.03.2020 р. МКІП остаточно отримало чинну назву, після відокремлення Міністерства молоді та спорту знов в окрему структуру.

Складний шлях перебудови роботи Міністерства був наслідком проведення глобального функціонального аудиту трьох (а потім двох) міністерств, а також розділення функцій формування політики, які залишилися в міністерстві, та реалізації політики, що здійснюються іншими центральними органами виконавчої влади. Таким чином, починаючи 32020 р. безпосереднім втіленням культурноінформаційної політики займаються профільні інституції (Державні служби, Державні агентства тощо), діяльність яких офіційно спрямовується і координується Кабінетом Міністрів України через відповідного Міністра. Що ж стосується конкретного переліку цих органів, то він теж постійно змінюється у процесі пошуку оптимальної моделі ефективного управління. Наразі через Міністра культури та інформаційної політики діють такі центральні органи виконавчої влади, як Держане агентство 3 питань кіно, Український інститут національної пам’яті, Державна служба України з етнополітики та свободи совісті, Державний комітет телебачення та радіомовлення, Державне агентство 3 питань мистецтв та мистецької освіти [14]. Також спеціальні функції щодо сприяння національно-культурному розвиткові України виконує бюджетна установа Український культурний фонд, яка не є центральним органом виконавчої влади, але ії діяльність також спрямовується і координується МКІП згідно із Законом про цей Фонд [15].

Відокремлення ж Міністерства молоді та спорту знов в окреме відомство було пов'язано 3 надмірністю та суперечливістю повноважень новоствореного у 2019 р. укрупненого Міністерства культури молоді та спорту, а також зі складнощами бюджетного фінансування такої структури, недостатністю 
бюрократичної підготовки керівників «гібридного» Міністерства й особливо 3 гострою дискусією в сфері інформаційної політики щодо можливого прийняття нових Законів України «Про протидію дезінформацію», «Про мас-медіа», яка триває й донині і потребує негайного вирішення.

Що ж до існування інших органів центральної виконавчої влади, спрямовуваних зараз через Міністра культури та інформаційної політики, то в результаті зрозумілим є таке: функції з реалізації державної політики повинні бути сконцентровані не в Міністерстві, яке зосереджено в основному на формуванні останньої, а саме в зазначених вище інших органах, що відповідає «духу і букві» закону України «Про центральні органи виконавчої влади» [16].

Фінансування сфери культури та інформаційної політики традиційно вважалося досить «хворобливим» питанням для України, де довгий час практикувалася модель фінансування культурно-інформаційної сфери за так званим «остаточним принципом». Натомість, у світі існують різні парадигми реалізації культурної політики, включаючи її фінансування, які отримали назву «патерналістської» («французька» модель) та «партнерської» («американська» та «британська» моделі», які ще називають «ринковими»). однак звичайно в «чистому» вигляді жодна 3 них не існує, а їх складові елементи знаходяться в постійній взаємодії. Фактично мова йде лише про превалювання тієї чи іншої моделі у процесі вибору тих чи інших напрямків та інструментів державного регулювання у сфері культури, а також реалізації культурно-політичних рішень.

На нашу думку, в контексті України доцільно було б поєднати елементи різних систем. Зокрема, з «американської» моделі можна запозичити систему податкових пільг для приватних осіб і корпорацій, які підтримують культуру, а також часткове або й повне увільнення від податків некомерційних мистецьких організацій, акцій, окремих митців. 3 «британської» - збільшення об’єму коштів, що виділяються на культуру, в державному бюджеті. 3 «французької», з одного боку, - контроль державних структур за процесом виділення та розподілу коштів, а 3 іншого - допомога та сприяння місцевих органів влади [17, с. 8]. 
Процес реалізації культурної політики, як зазначають дослідники, повинен містити певні види дій за визначеними напрямками (визначення культурних цінностей, цілей і пріоритетів; програми ініціатив і витрат, що відповідають цим цілям, які й сприймаються власне як формування культурної політики; моніторинг політики), а також мати власний політико-правовий інструментарій $[18$, с.8]. Це цілком узгоджується з бажаними напрямами модернізації системи фінансування культурно-інформаційної сфери.

Серед основних моделей фінансування державою сфери культури зарубіжні дослідники виділяють такі, що отримали умовні назви: держава-натхненник, держава-патрон, держава-архітектор і держава-інженер. Дуже важливо і те, що одна і та ж країна може використати одночасно взаємодоповнюючі моделі, тому запропонована класифікація не є взаємовиключною [19, с. 43-80].

Бурхливі зміни, які відбуваються в сучасному світі, призводять до становлення концепції сталого розвитку у сфері економіки держави, що робить ключовими у всіх сферах соціального життя, включаючи культуру, поняття «змін», «партнерства» і «знань». Отже, для України може бути перспективною модель держави-«патрона», де політика фінансування «на відстані витягнутої руки» відповідає сучасним міжнародним тенденціям, характеризується процесами децентралізації і регіоналізації культурної політики, що в цілому відповідає стратегіям соціального розвитку [17, с. 14].

Для України сьогодні потрібен стати доречним досвід підтримки культури у різних країнах світу. Так, Франція - це класичний приклад того, що прийнято називати континентальної моделлю культурної політики: держава, як на загальнонаціональному, так і на регіональному рівнях, не лише фінансує заклади культури (в тому числі і незалежні), але і активно формує культурне середовище. Головний гравець на цьому полі - Міністерство культури, яке було створено в 1959 році президентом Шарлем де Голлем. Зараз воно називається Міністерство культури і комунікацій, що свідчить про ефективність поєднання власне культурної та інформаційної політики держави. Цьому відомству приділяється провідна роль в підтримці французької ідентичності. Головний принцип - це 
відповідальність Міністерства за доступність найважливіших витворів мистецтва максимальній кількості людей, при тому, що особлива увага приділятиметься французькому мистецтву .Тому приклад Франції повинен стати показовим для України.

Що стосується Великобританії, то слід згадати, що саме в цій країні в 1940 р. був створений перший в світі прообраз міністерства культури - Рада з підтримки музики і мистецтв (Council for the Encouragement of Music and the Arts). Принципи, які лежать в основі британської культурної політики передбачають, активне втручання держави в справи культури і інформації. Головне правило - згаданий вище «принцип витягнутої руки»: участь без управління. Більш того, наразі британський Департамент культури, медіа та спорту не здійснює фінансування самостійно. В його функції входить розподіл бюджетних коштів через агентства, що мають статус некомерційних організацій i керуються незалежними директорами. Головним з таких агентств в Англї̈ є Рада з культури (Arts Council England), а в Шотландіï - Creative Scotland.

Радикальною відмінністю системи фінансування британських установ культури від країн континентальної Європи є те, що зазначені агентства розподіляють не тільки бюджетні гроші, а й кошти, які надходять від Національної лотереї - вона фінансує понад ніж третину витрат Ради з культури. Крім того, остання також отримує гроші від приватних спонсорів i фандрайзингових кампаній. Цей досвід зараз запроваджується і в Україні. Так нещодавно Кабінет Міністрів України схвалив проект Закону України «Про внесення змін до Бюджетного кодексу України щодо створення Державного фонду підтримки медицини, спорту, освіти, культури та науки» [20].

Такий підхід, поряд 3 традиційною в останні десятиліття увагою до креативних індустрій i заохочення підприємництва в сфері культури, відображений і в переліку головних напрямів британської культурної політики. Це підтримка мистецтва, забезпечення доступу молоді до культурної діяльності, підтримка програми «Місто культури» (заохочення культурного туризму), 
допомога організаціям культури в пошуку нових джерел фінансування та просування британської культури за кордоном.

Як і у Франції, культурна політика в Германії фактично замкнута на державі. 3 однією істотною відмінністю: в Німеччині вона повністю децентралізована. Тут немає федерального Міністерства культури, а культурні інституції отримують субсидії від урядів федеральних земель і муніципалітетів, при цьому часто роль міст виявляється значніше. Для німецької культурної політики істотним $є$ уявлення про державу як гаранта свободи слова та художньої незалежності. У Німеччині також працює правило «витягнутої руки»: державне фінансування не повинно впливати на способи висловлювання, i тому німецькі організації культури в основному працюють на основі самоврядності. Якщо в Великобританії державні принципи та напрями культурної політики переглядаються урядом раз на кілька років, то в Німеччині три головні принципи залишаються незмінними і гранично загальними: децентралізація, державна підтримка і різноманітність.

Федеральний уряд підтримує одне з найважливіших напрямів культурної політики Німеччини: просування культури, науки і німецької мови в усьому світі. Цю діяльність здійснюють незалежні організації, які у той же час отримують державне фінансування: Гете-інститут, Німецький академічний обмін (DAAD), Інститут міжнародних зв'язків (IFA) і багато інших.

США - це єдина велика в економічному і культурному сенсі країна, де немає сформульованої на рівні декларації або закону культурної політики. Вона визначається не державою, а через взаємодію різних акторів, i ïi можна сформулювати як «різноманітність, самостійність, ініціатива i широка підтримка». В Америці взагалі немає міністерства культури. Федеральний уряд містить кілька великих, що мають національне значення організацій: Смітсонівський інститут, куди входять 20 найбільших музеїв і деякі бібліотеки (Бібліотека Конгресу вважається підрозділом самого Конгресу). Та частина федерального бюджету, яка призначена культурі, розподіляється у вигляді грантів через Національний фонд мистецтв (National Endowment for the Arts). Спектр 
діяльності фонду надзвичайно широкий: від літератури до мистецької освіти. Культуру і мистецтво підтримують штати і муніципалітети, але їх роль несуттєва.

Позитивним є те, що наразі в Україні відбуваються реальні спроби подолання остаточного принципу фінансування культури та інформаційної сфери 3 урахуванням прогресивного досвіду зарубіжних країн. У державному бюджеті на 2021-й передбачено збільшення фінансування Міністерства культури та інформаційної політики на 52\% у порівнянні з 2020 роком. Таким чином, обсяг бюджетних коштів за Законом «Про державний бюджет України на 2021 рік» остаточно складає 12 млрд 524 млн 251,1 грн. [21], що є наочною демонстрацію поступової зміни сприйняття ролі культури і інформації для держави. Також впроваджуються новітні механізми іiі всебічної підтримки й інвестування галузі.

Таким чином, завдяки затвердженому бюджету у 2021 році МКІП України планує почати реалізацію запланованих програм, зокрема, проекту «Велика Реставрація», створення центрів культурних послуг, програм для народних художніх промислів і популяризації читання, системний розвиток і просування внутрішнього туризму, будівництво Національного меморіального комплексу Героїв Небесної Сотні - Музею Революції гідності, Музею Голодомору, Музею Бабиного Яру і галузевого державного архіву, програми інформаційної безпеки та медіаграмотності.

Планується створити два нові інститути: Державної служби охорони культурної спадщини та Державної інспекції охорони культурної спадщини.

Окрім цього виділено 300 млн грн субвенцій на місцеві програми. До того ж, бюджет передбачає і витрати в розмірі 50 млн грн на створення і розповсюдження патріотичних серіалів [22].

Отже, враховуючи світовий досвід публічного адміністрування у культурноінформаційній сфері, слід поступово відходити від застарілого принципу утримання мережі закладів та об'єктів культурно-інформаційної системи до режиму інвестування в неї, створення нових закладів та проектів, фінансування яких має відбуватися з урахуванням потреб економіки країни (регіону, міста, села, 
селища) зі створенням нових робочих місць, а також роботодавців та працівників цієї сфери.

В перспективі ж сучасна модель публічного адміністрування в сфері культури та інформаційної політики базуватиметься на державно-громадських засадах, де само Міністерство має виконувати ряд власних функцій (нормотворчу, організаційну, координаційну, інформаційно-аналітичну тощо), надавати якісні адміністративні послуги, здійснювати фінансування базової мережі закладів культури загальнодержавного рівня, розробляти основи інформаційної політики.

Окремі функції, зокрема переважна більшість яких стосується надання культурних та інформаційних послуг населенню, фінансуванню базової мережі закладів культури місцевого рівня, мають бути передані місцевим (регіональним) органам публічного адміністрування у цій сфері.

В результаті МКІП повинно перетворитися на сучасний модернізований міжвідомчий та координуючий орган, що формує державну культурноінформаційну політику на основі комплексного механізму (політичного, організаційно-правового, нормативно-правового, фінансово-економічного, інформаційно-аналітичного) з використанням новітніх принципів, форм і методів діяльності.

Таким чином, практичне вирішення теоретичних питань нової доктрини публічного адміністрування в інформаційно-культурній сфері в Україні 3 урахуванням світового досвіду потребує застосування адміністративно-правових засобів, а саме: (1) розробки і реалізації нормативно-правових актів, що зважають на специфіку регулювання традиційних і інноваційних культурних процесів; (2) здійснення експертизи нормативних правових документів, що приймаються, 3 точки зору їх впливу на сферу культури та інформації в цілому і окремі ії галузі; (3) проведення заходів по підвищенню правової культури населення і творчих працівників в царині культурної діяльності та мас-медіа, в тому числі незалежних журналістів; (4) розробки сучасних стандартів і нормативів надання культурних та інформаційних послуг населенню тощо. 


\section{3 Проблема торгівлі людьми в умовах збройного конфлікту на території України}

Одна з важливих світових проблем поліції та сучасного суспільства на сьогодні є пошук шляхів протидії та запобіганню торгівлі людьми. Це явище можемо назвати сучасною формою рабства і формою насильства, що спричиняє ризик для життя та здоров’я особи. Жодна країна світу не може цілком вберегти своїх громадян від цього тягаря, Україна не є винятком. Нестабільна соціальноекономічна ситуація, низький рівень правової культури населення, насильство проти жінок та дітей, корупція, політичний дисбаланс, конфлікт на сході України, безпринципність злочинців, нарощення попиту на дешеву робочу силу або неформальну працю, зростання потреб в сфері трансплантації органів створюють сприятливі умови для розвитку тіньового бізнесу у сфері торгівлі людьми. Актуальність проблеми торгівлі «живим товаром» в Україні, поглиблюється й тим фактором, що збройний конфлікт на сході став додатковим і сприяючим джерелом нарощення даного явища в нашій державі.

На сьогодні Україна є країною, з якої здійснюється експорт «живого товару» на світові «ринки» - до Туреччини, Італії, Польщі, Іспанії, Німеччини, Угорщини, Чехії, Греції, Об’єднаних Арабських Еміратів, Ізраїлю, Сполучених Штатів Америки та інших країн [23, с. 8].

Окуповані території, що знаходяться на сході України є чудовим фундаментом для процвітання свавільного беззаконня. Через непідконтрольність

цих територій активно зростає кількість випадків торгівлі людьми. Збройний конфлікт на сході країни призвів до того, що люди, які там проживали, мусили змінювати місце життя, втрачати роботу, доходи, впевненість у завтрашньому дні, усе це зробило особливо вразливим їх для експлуатації.

Конвенція Організації Об'єднаних Націй проти транснаціональної організованої злочинності визначає торгівлю людьми як здійснювані з метою експлуатації вербування, перевезення, передачу, приховування або одержання людей шляхом загрози силою або ii застосування або інших форм примусу, 
викрадення, шахрайства, обману, зловживання владою або уразливістю положення, або шляхом підкупу, у вигляді платежів або вигод, для одержання згоди особи, яка контролює іншу особу [24].

В українському законодавстві термін «торгівля людьми» подано у Законі України «Про протидію торгівлі людьми»: це здійснення незаконної угоди, об'єктом якої є людина, а так само вербування, переміщення, переховування, передача або одержання людини, вчинені з метою експлуатації, у тому числі сексуальної, з використанням обману, шахрайства, шантажу, уразливого стану людини або із застосуванням чи погрозою застосування насильства, 3 використанням службового становища або матеріальної чи іншої залежності від іншої особи» [25].

Законодавство у сфері боротьби 3 поширенням торгівлі людьми характеризується широким спектром не тільки національних законодавчих актів, але і міжнародними нормативно-правовими актами. А саме: Протокол про попередження i припинення торгівлі людьми, особливо жінками i дітьми, i покарання за неї; Конвенція Ради Свропи про заходи щодо протидії торгівлею людьми, Конвенція ООН про боротьбу з торгівлею людьми та експлуатацією проституції третіми особами, Закон України «Про протидію торгівлі людьми». Аналіз нормативно-правового поля протидії та запобігання торгівлі людьми, показує, що не дивлячись на те, що антитерористична операція на території Донецької та Луганської областей проводиться вже не один рік, засоби боротьби 3 явищем продажу «живого товару» залишилися і по сьогодні такими як і в мирний час.

Сфера торгівлі людьми в тіньовому секторі економіки здійснюється з метою трудової й сексуальної експлуатації, а також для використання в жебрацтві, порнобізнесі, збройних конфліктах, втягнення у злочинну діяльність, вилучення органів, проведення дослідів над людиною без її згоди та інше.

Збройний конфлікт дає можливості не лише для протизаконного переміщення зброї, боєприпасів, наркотиків, але й людей. Нова для України група ризику, що може легко стати жертвою тіньового ринку є вимушені 
переселенці або внутрішньо переміщені особи із зони збройного конфлікту на Сході України. Основними причинами поширення торгівлі людьми є такі фактори: нестатки; привабливість кращих умов життя в іншому місці; неможливість працевлаштування; організована злочинність; дискримінація жінок; насильство над жінками; політична нестабільність; збройні конфлікти; попит на послуги в секс-індустрії; важке економічне становище громадян і безробіття [26, с. 28-29]. Перераховані чинники мають позитивний вплив на поширення торгівлі «живим товаром».

Через невизначеність перспектив щодо подальшого розміщення та працевлаштування, побутові труднощі та брак ресурсів (зокрема, фінансових), вимушені переселенці або внутрішньо переміщені особи із зони збройного конфлікту $є$ особливо вразливими та схильними до прийняття сумнівних пропозицій вербувальників. Значна кількість переселенців намагаються отримати притулок чи роботу за кордоном, а брак знань міжнародного та внутрішнього законодавства інших країн відносно статусу біженця чи шукача притулку сприяє стати обманутим шахраями чи торгівцями людьми. Саме тому, 3 метою недопущення торгівлі «живим товаром» та протидії цього явища, на окупованих територіях Сходу України необхідно:

- посилити взаємодію оперативних підрозділів Національної поліції та військовослужбовців, що несуть службу в зоні Операції об’єднаних сил на пунктах пропуску;

- постійно проводити роз'яснювальну роботу у цьому напряму військовослужбовцями та волонтерами, що знаходяться у зоні Операції об’єднаних сил, серед населення;

- поглибити механізм проведення спільних заходів оперативних та слідчих підрозділів поліції у виявленні, документуванні та розслідуванні кримінальних правопорушень цієї категорії справ.

Однією з найнебезпечніший та найстрашніших форм торгівлі людьми, на нашу думку, є торгівля людьми з метою вилучення у них органів або тканин для трансплантації. «Чорний ринок людських органів», на жаль, активно 
розвивається в Україні. Найчастіше саме громадяни нашої країни стають жертвами «чорних трансплантологів» на світовому ринку. Збройний конфлікт діє як каталізатор для збільшення правопорушень в цьому аспекті.

На сьогодні в Україні, є ознаки, які вказують на розширення «чорного» ринку органів і тканин людини. Недоліки у законодавстві, яким регулюється пересадка органів, і пов'язані з цим комерційні інтереси, корупція і шахрайство створюють підгрунтя для розвитку незаконної торгівлі органами людини. Такі злочини вже вийшли за межі національних, тому боротьба 3 ними вимагає скоординованих зусиль світової спільноти [27, с. 10]. «Чорна трансплантологія» $\epsilon$ глобальною міжнародною проблемою. Найстрашніше те, що через це явище гинуть ні в чому не винні люди, а частіше за все і діти. Про це свідчать неодноразові зникнення дітей з невідомою їх подальшою долею. Або коли їх знаходили вже мертвими без деяких життєво необхідних органів.

Незаконне вилучення у потерпілого органів чи тканин для трансплантації означає примушування потерпілого до вилучення у нього органів, тканин, а також крові людини чи іiі компонентів шляхом застосування фізичного чи психічного насильства, погроз, обману, з використанням безпорадного стану чи його залежність від винного. Отримання згоди потерпілого на вилучення у нього органів, тканин, крові все одно утворює склад злочину передбаченого ст. 149 Кримінального кодексу України. Незважаючи на те, що люди нібито добровільно погоджуються на вилучення органів, відповідно до законодавства України отримання згоди потерпілого на вилучення у нього органів, тканин, крові все одно утворює склад злочину ст. 149.

Для вилучення у людини органів чи тканин шляхом примушування або обману, характерним є вчинення їх організованими злочинними групами, до складу яких можуть входити медичні працівники (лікарі швидкої медичної допомоги, анестезіологи-реаніматологи, хірурги, операційні сестри, судовомедичні експерти та ін.), а також особи, які не входять до числа медичних працівників, та належать до кримінальних структур, що спеціалізуються на вчиненні таких злочинів [27, с. 10]. 
Злочини у сфері трансплантації органів або тканин людини характеризуються певними негативними факторами, а саме: наявністю «тіньових» схем роботи медичних установ, відсутністю всеукраїнського банку органів і тканин, загальнодоступності медичної допомоги, недостатньою кількістю клінік з пересадки органів, недостатнім рівнем розвитку вітчизняних клінік з трансплантації органів, недоліками у діяльності медичних установ, неправильним уявленням у суспільстві про донорство, недостатнім розвитком у суспільстві принципів гуманізму, а також практики добровільних пожертвувань, відсутністю системи заохочення фізичних осіб за добровільне пожертвування органів, існуванням «трансплантаційного туризму» (продаж органів і тканин при виїзді за кордон), наявністю «чорного ринку» людських органів і тканин, корупцією медичних працівників, скрутним матеріальним становищем осіб, які пропонують власні органи на продаж, чутками про викрадання людей з метою продажу їх органів, крадіжками органів хірургами під час планових операцій, відсутністю належної роз'яснювальної роботи медичних установ про правильне донорство (пожертвування органів), недостатнім контролем за діяльністю медичних установ з боку громадських організацій, можливістю заробити на продажі своїх органів, недостатньо суворими санкціями кримінального закону за здійснення незаконної трансплантації органів тощо [27, с. 11]. На сьогодні через тимчасово окуповану територію йде активне переміщення жертв торгівлі людьми, оскільки «торгівлею людьми вважається злочин, що був учинений як при перетині державного кордону, так і без цього, що не є його визначальною ознакою» $[23$, с. 5$]$.

Проте потрібно звернути увагу на те, що в межах країни набагато легше знайти особу, ніж за ії межами. Вважаємо за необхідне розмежування торгівлі людьми в межах країни та торгівлі людьми з перетином державного кордону. Таке розмежування повинне передбачати різне покарання у санкції статті Кримінального кодексу.

За торгівлю людьми передбачена кримінальна відповідальність за статтею 149 Кримінального кодексу України, в якій указується: «Торгівля людиною, а 
так само вербування, переміщення, переховування, передача або одержання людини, вчинені з метою експлуатації, з використанням примусу, викрадення, обману, шантажу, матеріальної чи іншої залежності потерпілого, його уразливого стану або підкупу третьої особи, яка контролює потерпілого, для отримання згоди на його експлуатацію» [28]. Звернувши увагу на санкцію ст. 149, що передбачає кримінальну відповідальність від 3 до 8 років позбавлення волі, маємо сказати, що для такого виду злочину таке покарання є досить гуманним. Вважаємо, що термін кримінального покарання за торгівлю людьми має бути значно вищим. Насамперед це пов’язано з тим, що цей злочин руйнує людську гідність, життя, стає причиною психологічної травми, не всі люди здатні відновитися після пережитого, не усіх жертв є можливість у поліції знайти за кордоном та повернути додому.

Отже, поширення торгівлі людьми через непідконтрольний схід України є глобальною проблемою, що потребує негайного вирішення. Військовий конфлікт породжує грубі порушення прав і свобод людини, зокрема сприяє й торгівлі людьми. Українська влада повинна вберегти своїх громадян від цих злочинів i встановити таке покарання за цей злочин, яке буде суттєвим i справедливим. На законодавчому рівні необхідно прийняти зміни, що значно посилять юридичну відповідальність за статтями Кримінального кодексу відносно торгівлі «живим товаром» (секс-торгівлі, рабства, безоплатної трудової експлуатації, незаконне переміщення дітей за кордон), а також окремо вважаємо слід внести статтю в цей кодекс із суттєвими санкціями щодо «чорної трансплантології» та «трансплантаційного туризму». Цілком логічно, що потребують змін і нормативно-правові акти відносно протидії та запобіганню торгівлі людьми уповноваженими органами Національної поліції в яких би віддзеркалювалися особливості проведення таких заходів на тимчасово окупованій території. 


\section{SECTION 2. CIVIL LAW}

DOI 10.46299/ISG.2021.MONO.LEGAL.II-34-66

\subsection{Statute of limitation - time coordinates of the substantive right to claim.}

Social processes and phenomena, human activity, public policy, lawmaking and law enforcement occur over time. In other words, any social relations, including those regulated by law, are subject to temporary influence. They have a certain duration, sequence and temporal relationship. Time characterizes not only external to the observer phenomena, it is also inherent in the internal nature of person. Thus, in modern science it is customary to emphasize not only the reality of purely physical manifestations of existence, but also the socio-historical aspects of it. In fact, giving time only a physical interpretation as duration, term or period, it is not possible to cover all its multifaceted manifestations. No matter how objectively the course of time, its perception, determination of the influence on the state of matter, in the end, the study of temporal manifestations is possible only if this phenomenon is reflected in the human mind. After all, the existing order of processes covers the progress of society, community, and ultimately, the very lives of individuals.

Public relations, whether they have a legal basis or not, are certain objective phenomena that exist in space and time. The subjective rights and responsibilities of the parties to this relationship also have spatial and temporal boundaries, moreover, quite often it is the time factor that sometimes has a decisive influence on the content of subjective law or leads to its change. Terms can be considered from several points of view. Of course, it is important to characterize the substantive term as the time of occurrence (termination) or duration of the relationship. At the same time, in the literature, civil terms were also assessed as criteria for the legitimacy of a person's behavior or from the standpoint of their attribution to one of the conditions that determine the content of the relationship [29, p. 39]. Therefore, the study of civil law terms in terms of their impact on the effectiveness and validity of subjective civil law is of methodological importance, as it allows to establish the relationship between the 
objective temporal phenomenon and the legitimacy of the volitional behavior of the subjects of relations.

It should be noted that the current regulation of legal issues regarding the duration of civil relations has reached a certain qualitative level, which creates the possibility of building a holistic concept. First of all, in our opinion, this applies to the institution of statute of limitations. Today's level of legal analysis and research of legislation and law enforcement practice allow to summarize the existing empirical material and reveal in detail the essence, legal nature and principles of this type of civil terms as part of a single regulatory mechanism. The new Ukrainian civil legislation has made a number of significant changes to the statute of limitations. Their necessity was put to the need of the day as a result of a detailed analysis of relevant theoretical developments and practice of application of the provisions of this institute. At the same time, the issue needs further study and improvement of legislative tools. There is an urgent need for this, which is becoming apparent from the very beginning of the application of the latest civil law. The study of the evolution of the regulated relations themselves, in connection with the development of their legislation, must be reflected in the adjustment of doctrinal concepts, and the new theoretical conclusions should lead to some reassessment of the importance of the statute of limitations and its place in civil law.

At the moment of violation of the subjective civil law, the authorized person has a protective subjective substantive right. Its essence is the requirement to the violator to restore the violated legal position by means of specific legal remedies defined by law [30, p. 14]. One of the mechanisms of implementation of these methods of protection is judicial, which in the doctrine is considered the most effective and efficient. We can note that the claims arising from the protection relationship are aimed at protecting regulatory civil rights and interests [31, p. 6-8]. In order to use this mechanism, the person authorized by the protective legal relationship is given a secondary right - a claim, after which the necessary result is achieved: the claim can be enforced. To exercise the substantive right to sue (claim) is set a limited period of time - the statute of limitations. 
Like any term, the statute of limitations determines the beginning and end of a phenomenon that has a material existence in space. Since prescription acts as a legal category, this phenomenon must have a specific legal meaning. In other words, it is necessary to clearly define what is the subject of the statute of limitations. In science, certain opinions have been expressed regarding the formulation of the subject, the existence of which occurs during the period of time, called the statute of limitations. It is necessary to point out rather big variety of these thoughts. In particular, it was stated that the statute of limitations applies to civil relations [32. p. 162], it extinguishes the possibility of enforcement of the violated civil law through a civil lawsuit [33, p. 332], its subject is the protection of the lawsuit [34, p. 157], coercive protection of the law by filing a lawsuit to court [35, p. 468], etc.

The literature also indicates that the statute of limitations is the institution of civil law, the effect of which does not apply to all subjective rights, but only to those of them that are the rights of claim [36, p. 4]. There are other formulations of the legal purpose of the statute of limitations, for example, those that the time factor - statute of limitations is important only in court proceedings, but if the obligation is fulfilled voluntarily, the main reason for which time is given legal significance [37, p. 267]. We must state that the above definitions are not completely correct and need further interpretation. First, it should be clarified that in this context we are talking about the rights of claim, which are part of only the protective legal relationship, only such claims can be statute-barred. The right of claim, laid down in the regulatory obligation, aimed at achieving the normal development of the relationship is therefore not related to the statute of limitations. The regulatory subjective power is not covered by the time of the statute of limitations, the beginning and end of this period do not affect its existence.

Secondly, it should be borne in mind that not all legal requirements are limited in their duration to the period during which the statute of limitations expires. Thus, claims aimed at achieving a certain property or other result due to the active behavior of the managed entity are not subject to statute of limitations, their implementation will take place in court, out of court or voluntarily during other periods. Only the secondary right to sue can be delayed, ie repaid with the expiration of the statute of limitations. It 
is not aimed at a specific property consequence, but at the emergence of another legal relationship with the participation of the competent authority of the state - the court. This right is exercised through unilateral action, while the debtor's duty will be passivity. He must file a lawsuit.

The legislative solution to this issue should be noted separately. Article 256 of the CCU defines the statute of limitations as the time limit for going to court with a request to protect one's civil right or interest. The civil law of most foreign countries formulates the purpose of this period somewhat differently. For example, in Art. 195 of the Civil Code, Article 196 of the Civil Code of the Republic of Belarus [38] states that the statute of limitations is a period for protection of the right of claim of the person whose right is violated. Another definition is found in Art. 177 of the Civil Code of the Republic of Moldova: statute of limitations is a period of time during which a claim arising from a violation of a person's right or a legally protected interest can be satisfied [39].

Let's try to determine to what extent the above formulations correspond to the actual state of affairs, and what, in the end, is the real subject of the statute of limitations. It is quite obvious that it can only be a phenomenon that arises from the beginning of its course and ceases with its emergence. Ukrainian law stipulates that a person whose right has been violated may apply to the court for protection within a specific period of time - the statute of limitations. The commented wording of the legal norm testifies to a certain mixing in the main Ukrainian civil law act of substantive and procedural legal possibilities of protection of the violated right. At the same time, civil science has long distinguished the concept of the right to sue in the substantive and procedural sense. The right to sue in the procedural sense is a legally conditioned possibility of a person to become a participant in a court proceeding, which takes place at the request of this person. In a narrower sense, it is the right to go to court, in essence, it is a question of the procedure and conditions for filing a lawsuit.

In our civilization, many researchers have paid attention to the issue of delimitation of the right to sue in the substantive and procedural sense. As noted by V.P. Gribanov, the right to sue from a procedural point of view, which is in fact a form 
of exercising the substantive right to protection, contains, firstly, the right to go to court to protect the violated or disputed right or interest, and secondly, the ability to use all statutory rights when considering the case, finally, the opportunity to appeal in the prescribed manner the decision of a state body [40, p. 113]. Despite a certain controversy of such a broad content of this phenomenon, the opinion that the implementation of substantive legal requirements has a procedural order still seems unquestionable. It is through the claim form that the enforcement of the protective substantive right is achieved. Such implementation takes place through the use of a public law mechanism, the participants of which are the law enforcement body and the parties to the trial. But in order to be able to become a party to such a public-law relationship, it is not necessary to prove the existence of substantive law and the facts of its violation or challenge. These facts will be clarified in court and, if it turns out that the applicant's substantive right is missing or not violated, the claim will be denied. Thus, there are often situations when the substantive claims addressed to the defendant are not satisfied, but the requirements for the applicant's right to a trial will be satisfied.

In order to adjust the currently commented legal definition to the reality of specific relationships, in the literature of the time there was an opinion about the need for pre-trial clarification of the legal relationship of the person applying to the court with the object of legal protection, the presence of subjective substantive law condition and legal nature of the stated requirements [41, p. 135-136]. This approach was justified by the fact that a preliminary examination of this issue may reveal that the subjective right does not belong to the applicant or it is not violated by the defendant. Or it may turn out that the law does not provide for judicial protection of the claim. If we consider that the statute of limitations is a time to go to court, we must agree with the position of these researchers, which in the case of establishing after filing a lawsuit the absence of one of the prerequisites for the right to sue, the statement of claim should be denied.

However, as we have repeatedly noted in this paper, such a concept has not withstood the test of time, because it often leads to legal collapse. In fact, the circumstances surrounding a person's legal relationship with substantive law, the 
legality of his claims and the state of the law itself can only be clarified on the merits. In particular, the issue of challenged rights is often not the defendant's conduct, but the impossibility of its implementation without a court decision, and this issue is subject to review by the jurisdiction when considering the case on the merits, and not when it is initiated. Therefore, the proceedings must be instituted, and the discovery in the case of the above circumstances entails a refusal to satisfy the claim. The same consequence occurs when during the consideration of the dispute it was established that the statute of limitations (period of validity of the claim) has expired and there are no valid reasons for its restoration.

However, despite the fact that this fact is established in the court decision, it fixes the expiration of the statute of limitations at the time of filing the lawsuit. Therefore, the statement that the right to protection is terminated from the moment of entry into force of the court decision to dismiss the claim with the expiration of the statute of limitations cannot be considered correct $[42$, p. 3]. In fact, the right to protection continues to exist after that, but is no longer secured by legal capacity. Only the right to sue (claim) is terminated, but, as mentioned above, the court only finds that it ceased after the expiration of the statute of limitations, ie at the time of filing the claim was absent.

The commented issues are not least caused by the sometimes unsuccessful legislative regulation of the relevant legal mechanisms. Thus, in some regulations there are provisions that with the expiration of the statute of limitations, the right of a person to sue is terminated. Is such an wording only a misstatement of a generally accepted rule (in this case, the statute of limitations, despite the wording, is limited by the substantive legal requirement), or should the provisions of the law be taken literally (the right to appeal to a jurisdiction is delayed). The first variant of the answer to the posed question deserves more attention. After all, as is well known, in practice the very right to judicial protection, and not to go to court, is limited by the statute of limitations, despite the frankly erroneous wording of this issue in Art. 256 of the Civil Code of Ukraine. This view is supported by most researchers [43, p. 56]. However, when it comes to international regulations, we must agree with M.G. Masevich: sometimes 
with the expiration of the statute of limitations also terminates the procedural right to sue $[44$, p. 142].

Thus, it is quite obvious that the subject of the statute of limitations cannot be the right to go to court, as it is a procedural power of a person. This power is not only not subject to limitation, it does not depend on the existence of a person's substantive law and its violation. Attempts by some researchers to present the statute of limitations as a time limit for filing a lawsuit [45, p. 135] have long been critically evaluated in our civilization [46, p. 27-28]. A person may apply to the court both before and after the statute of limitations, this, incidentally, is explicitly stated in Part 2 of Art. 267 CCU. Therefore, the definition of Article 256 of the CCU as to which phenomenon of a legal nature is regulated by the statute of limitations should be considered unsuccessful.

It would seem that the above theoretical and legislative definitions of the statute of limitations as a term for protection of the infringed right on the claim of its holder are more successful. However, they can be acceptable only if they are further interpreted. Indeed, one cannot agree with the literal understanding that the statute of limitations is the time during which a person can count on the protection of his violated right by the court, and even more so - the term of compulsory protection of the right [47, p. 80]. As E.Ya. Motovilovker rightly points out, without a certain explanation we get a picture when it seems logical that the term for protection of the right to sue is the term for judicial protection of the right, in other words - the time to make a decision that satisfies the claim. But the assertion that the judicial satisfaction of the claim is a protection of the right to sue in the sense of the legal definition of the statute of limitations (under Article 195 of the Civil Code of Russian Federation) is absurd, it completely distorts the real purpose of the statute of limitations. The statute of limitations cannot be considered a term for protection of a person's claim. After all, such a right does not exist during the statute of limitations: it arises not from the person's awareness of the fact of the offense, but from the moment of filing a lawsuit, when the statute of limitations has expired due to exhaustion of limited powers, and lasts throughout the trial material dispute. It turns out that the thesis on the statute of 
limitations as a time to protect the right to sue, enshrined in p. 195 of the Russian Civil Code, the idea of the term for the phenomenon that does not arise and does not exist during its course and, therefore, is the idea of a meaningless period, ie insolvent thought [48, p. 23-24].

Through the decision of the law enforcement body of its decision there is a compulsory realization of the protection and legal authority of the person, his real protection. The time for a court decision is determined by procedural law and can not be equal to the statute of limitations. Moreover, its course is legally taken into account from the beginning of the process, while the statute of limitations begins from the moment of violation of the subjective right. This period is normatively addressed to the law enforcement agency and in the literature is called the term of office [49, p. 57]. The assumption that the protection of the right begins from the time of the offense, ie from the beginning of the antiquity, is contrary to common sense, so the idea of statute of limitations as a time to protect the right of action refers to the phenomenon that does not occur and does not exist [48, p. 24]. Thus, the statute of limitations does not regulate the term of judicial protection of rights, it does not mediate the duration of justice.

However, there is nothing wrong, at first glance, with considering the statute of limitations as a term of protection of the right, explaining that the term "judicial protection of the right" refers only to the acquisition of such an opportunity. This is the path taken by the Russian legislator and some researchers on this issue. But in reality, the problem here is more serious than a simple interpretation of legal definitions. In the literature it is accepted to identify the concept of "term of protection of the violated right" and "term of exercise of protection and legal authority" [50, p. 101]. But, in fact, this is not quite the right approach. After all, although the protection of the violated regulatory right is the goal achieved as a result of the implementation of the protection requirement, but in this case, respectively, the concepts of "statute of limitations" and "term of protection" are identical. And this is not true at all.

Thus, we come to the conclusion that this legal approach is inadequate to the real protective material interactions, according to which the protection of a subjective right, ie consideration of a case and decision-making by a law enforcement body, occurs 
during the statute of limitations. As we can see, the statute of limitations does not cover either the time to apply to the court for judicial protection, nor the time for the jurisdiction to exercise such protection. What then does it regulate? There is only one answer to this question. The statute of limitations is not a period for protection of the violated substantive right, but a period of time during which a person has the opportunity to obtain such protection by filing a lawsuit. Actually, the duration of the authority to exercise such an opportunity is determined by the statute of limitations. So, in fact, the statute of limitations is the time during which a person, subject to a unilateral action - filing a lawsuit, acquires the possibility of judicial protection of the violated subjective right. Therefore, the subject of the statute of limitations is the right of a person to receive judicial protection of his violated right. Such a right is also called a substantive right to sue or claim, so the claim itself is a legally significant phenomenon, the existence of which is limited by the statute of limitations.

In this sense, the wording of the statute of limitations should be understood as a term for protection of the right, where the notion of duration of judicial protection is defined as the period of possibility of obtaining it when filing a lawsuit during this time. Therefore, the possibility of obtaining judicial protection is indicated and is the right to protection at the suit of the right holder in the sense of the commented doctrine. And it is she (the possibility of judicial protection of her violated right) ceases with the expiration of the statute of limitations, in which, incidentally, researchers of the problem are almost unanimous. The statute of limitations is the time limit of one of the elements of the right to protection. It repays the right to apply for a decision on protection.

When the applicant exercises his right to sue, the public law claim for protection of the right is sent to the address of the state body, and the substantive legal claim is addressed to the defendant. Thus, the right to sue in the substantive sense is an opportunity through the mediation of the court (which is carried out in procedural form) to enforce the protection of their subjective civil law. Filing a lawsuit is one of the manifestations of the implementation of the substantive protection right, which after the violation acquired, in particular, the property to be enforced. From this point of 
view, the statement of S.I. Vilnyansky seems to be valid, according to which the substantive right to sue is the right to obtain the forced realization of one's subjective right, even against the will of the obligated person [51, p. 179-180]. At the same time, we must emphasize once again that the implementation of the claim is only one of a number of powers that are part of the protective relationship. A person may not exercise his right to receive compulsory protection. The fact that seeking legal protection is a right, not an obligation, of its holder has long been indisputable. As early as the 19th century, A.L. Borovikovsky pointed out that everyone had the right to exercise his right to the extent he wished - to protect him from violations or to tolerate them [52, p. 7]. Therefore, the thesis of the repayment of a subjective right as a punishment for its nonfulfillment has a long-standing critical assessment.

Civil law, in regulating issues related to the enforcement of protection and legal requirements, postulates the statute of limitations as a general phenomenon for all claims [53, p. 599]. However, he also cites a number of exceptions to this rule. However, in our civil doctrine, the controversy continues over the essence of certain statutory protection and legal requirements, which, given their internal nature, cannot be the subject of a statute of limitations. These are some requirements that, due to their special properties, cannot be met at all, as there can be no reason to start the statute of limitations. It is because of their legal nature, and not because of the prescription of the law, that, according to scholars, they are not subject to the rules of the statute of limitations. Some positions of researchers on this issue, which lie in the plane of the desired adjustment of the relevant legislation (de lege ferenda), are of interest and should be taken into account in the construction of normative material and the formation of case law.

First of all, it should be emphasized once again that protection and legal powers, which are exercised without the involvement of judicial authorities, cannot be related to the subject of the statute of limitations. In particular, they include the right of a person to apply measures of operational influence. Such, for example, is the right to withdraw from the contract due to its non-performance or improper performance by the other party [46, p. 58-49]. Another example: if the contractor violates the terms of 
the contract, the customer has the right to independently or with the involvement of others to correct deficiencies and demand reimbursement of their costs or a corresponding reduction in wages (Part 1 of Article 852 of the CCU). Similar powers arise for the buyer of a low-quality thing in the case of self-elimination of defects: he may also require the seller to reimburse the costs incurred (Part 1 of Article 678 of the $\mathrm{CCU})$. What is the content of this protective legal relationship and what is the term of realization of the specified right of the creditor?

V.V. Luts points out that the creditor can fulfill these requirements during the statute of limitations [54, p. 106]. However, it remains unclear which of them is the statute of limitations and from what moment it should be calculated? In our opinion, the statute of limitations has nothing to do with the period of exercise of these powers. As for the duration of their implementation, we will already conduct relevant research in this area and provide proposals for their regulatory reproduction [55, p. 99-100]. It is also erroneous to claim that the statute of limitations is widely used: not only in the case of legal protection of infringed subjective rights, but also in other protective relationships - in cases of separate proceedings and tax disputes, in a court of law, etc.

But, of course, more interesting are the scientific studies on the issue of nonextension of statute of limitations to protection requirements in the framework of the implementation of the claim. For example, the thesis on the impossibility of applying the statute of limitations to claims for invalidation (invalid) of normative legal acts and decisions of government bodies, local self-government seems quite logical. After all, this document, being an act of long-term action, in the case of its objective illegality continues to violate the subjective substantive law, regardless of the time of recourse to the court [56, p. 13]. It applies to an indefinite circle of people and has no one-time effect over time.

In fact, the refusal to satisfy the claims due to the omission of the statute of limitations by the authorized subject actually means the following: during the trial the court found a violation of the plaintiff's subjective civil law by the defendant in the manner specified in the application judicial protection of this right has expired. Thus, refusing to protect the violated right after the statute of limitations, the court 
simultaneously finds that it was violated as a result of the adoption of an illegal act. Speaking about the illegality of the act, the law enforcement agency does not satisfy the requirement to recognize it as such. But this act applies to all parties to the relationship, and its invalidity may be established at the suit of any of them. Therefore, it would probably be impractical to set different deadlines for the protection of subjects of the same right depending on certain factors, such as the time of creation of a legal entity.

In the Russian Federation, despite the absence of such a rule, the highest judicial authorities have determined that the statute of limitations may not be applied in the case of an appeal against a normative legal act, unless otherwise provided by law. Ukrainian jurisprudence today, on the contrary, is that given the lack of such an adjustment in Article 268 of the CCU, there are no formal legal grounds for nonapplication of the statute of limitations on the requirements for illegal recognition of regulations of state bodies. Moreover, in practice, the limitation period for the specified requirements from the date of issuance of the act is applied, without taking into account the period when the specified document began to violate the substantive rights of the person. Well, since the consideration of these claims is now referred to the jurisdiction of the administrative courts of Ukraine (we have already noted that the Administrative Processual Code of Ukraine is largely inconsistent with the basic principles of protection of the private right of the person he is called to protect in case of violation of lawful authority), the question in general has become grotesque.

When considering these claims, administrative courts do not apply the provisions of Chapter 19 of the Civil Code of Ukraine on the total duration of the claim. The most common justification for this position is that the relationship for the issuance of these acts and their implementation are administrative in nature, and such a vertical provisions of civil law do not apply by virtue of a direct indication of the law. Therefore, the duration of the claim is determined by the six-month period of recourse to the court, established by Art. 99 of Administrative Processual Code of Ukraine. In our view, such an enforcement approach is incorrect, and the court hearing the dispute must be guided by general principles as to the fact that such a claim cannot be met. We 
are talking about the need for normative restoration of the rule, once enshrined in Part 4) of Art. 268 of the CCU (but for some reason abolished in 2011) and giving it a more realistic content with a wider application, not limited to the protection of property rights.

In Russian law, the requirements that are not covered by the influence of the ancient institution, include negatronic claims (Part 5 of Article 208 of the Civil Code of RF). In journalism, such a normative decision is explained by the ongoing nature of the offense, the only important thing is that at the time of judicial protection, this offense has not yet ceased. The rationale for such an approach should be within the theory of ongoing violation. According to her, certain violations (including the owner's right to use the thing) are ongoing. In this state of the relationship there is a continuous series of individual violations of subjective law. For each of them from the moment of violation there is a protective claim and a separate course of the statute of limitations begins. The last of them will actually start before the end of the violation and will end in three years. For the practical application of this legal approach, this means that the statute of limitations for claims to terminate an ongoing violation, starting from the initial moment, does not end (which, in fact, is the same as not extending it to the requirements arising from this violation).

Issues related to the possibility of filing claims for an ongoing offense have been studied in detail in another paper [57, p. 405-410]. Therefore, without repeating the arguments given in it, we will only note that the modern Ukrainian civil legislation in general does not accept the idea of not applying the statute of limitations to the requirements for ongoing violations. We believe that this position is quite balanced, because otherwise the definition of ongoing can cover a large number of violations of the subjective civil rights of the individual. But in the field of special legal regulation it is quite acceptable to introduce a rule not to apply the statute of limitations to certain claims for ongoing violations, say, those that infringe on the owner's right to use the thing $[42$, p. 8] or those arising from the issuance of illegal regulations by the state. or local government. 
For a long time, the allegations about the non-extension of the statute of limitations to statutory claims and claims for recognition (positive - to confirm the existence of the right and negative - to confirm the absence of the right) were quite controversial in the literature. This was explained by the fact that in this case there is no violation of the law, but only the plaintiff's fears about its possible violation. In support of this thesis was a strong argument: the recognition of the right is one way to protect it, but the meaning of any defense is lost if the court rules like "the plaintiff has the right (and in this context - the court agrees with the claims), but it has long been deprived of the right to protection [58, p. 4-6]. This point of view is generally noteworthy, and at the same time needs some adjustment. Indeed, with regard to the above requirements, the application of the statute of limitations has its own features that allow them to be identified with the actual non-application of the legal institution. But this is not due to the absence of an offense. The development of such a concept can lead to the absurd conclusion about the possibility of the existence of a claim without violating the protected right. The matter is different.

Let's take a closer look at the possibility or impossibility of filing claims aimed at achieving certainty as to the presence or absence of a certain civil subjective right of an authorized person. As in other cases, a person seeking the recognition of his right has the opportunity to go to court only if it is violated or challenged by other persons. If the court, in considering the dispute, finds that at the time of filing the claim, the subjective right of the plaintiff was not violated, he must dismiss the claim. The view of the existence of claims against a person who is not a violator of substantive subjective law (which precludes the satisfaction of such a claim) [50, p. 144] seems to us unfounded. Thus, one of the important preconditions for the emergence of the right to sue in the material sense is the violation of the substantive regulatory relationship by the person liable for it. From this begins the statute of limitations, and the legislation does not contain any exceptions to the general rule for these cases.

The question, in fact, is the duration of the authority to make such a claim. However, given the different temporal characteristics of the regulatory relationship for absolute and binding relationships, it may have different meanings. If the rules of the 
statute of limitations apply to the commented claims, then there is no difference in its application to the claims arising from the violation of absolute or binding relations: the claim will continue within the statute of limitations. When these requirements are not met, there is a significant difference. For violations arising from absolute relations, the claim belongs to the person throughout the duration of its regulatory right. While the requirements arising from the violation of a relative relationship, as a rule, can not relate to the presence or absence of a subject of a certain regulatory right, because it is from the time of the offense, it ceased. Such requirements can only have a retrospective focus, such as claims for invalidation of transactions at the time of their conclusion.

Violation or challenge of a right as a basis for its protection by recognition is usually an ongoing action. In this case, it would seem, it is also possible to apply the theory of ongoing violation, which was mentioned in the previous paragraphs: the offense can be thought of as a series of permanent violations and from each of them begins its own course of limitation. After all, the decision of the court on the question of the presence or absence of a legal relationship does not change anything in it, but only states and confirms what objectively happened before, outside and regardless of the trial. Hence the conclusion about the expediency of legislative establishment of a rule that the statute of limitations does not apply to such requirements, it is more logical than to calculate a new statute of limitations every second during the ongoing violation, which ultimately provides the same legal result.

For example, subject A has committed various acts for five years, indicating that he did not recognize the right of subject B. Based on the above, the latter may sue for recognition of his right at any time within the period from the beginning violation before its completion. It is obvious that with the cessation of the violation (nonrecognition or challenge of the right) the right to a claim for recognition will cease (as well as the apparent statute of limitations, which began with each of a number of violations and has not yet expired. However, from this offense, the authorized person may have other requirements that will be met as a general rule. These claims arising from this offense will have a period of existence: for damages - three years from the date of their infliction, for termination of a certain action - the same time from the 
moment of its commission (taking into account, of course, the time when such violations occurred known to the Commissioner), etc.

However, as we have already pointed out, the theory of ongoing violation cannot be used as a basis for determining the range of requirements to which the statute of limitations does not apply. After all, if the current legislation agreed, the definition of ongoing could be summed up by most violations of a person's subjective civil rights: non-return of the thing after the lease, non-payment after a specified date, violation of possession or use of the thing, etc. [57, p. 407-409] . Rather, it is necessary to define some of these requirements in a special article of the law, as, for example, done in Part 5 of Art. 208 of the Civil Code of RF.

Thus, it can be agreed that in some cases, when in order to eliminate uncertainty in the legal relationship requires judicial discretion, it would be impractical to apply the statute of limitations to the relevant requirements [59, p. 81]. But such an approach is possible only if these requirements will be directed not against the offender, but to establish the law enforcement agency of a fact. In the literature, those that are not subject to non-satisfaction include, for example, requirements for the recognition of a person who has lost the right to use housing [46, p. 64]. In these circumstances, the presentation of the relevant claim will not be considered the implementation of a protective claim, but rather should be classified as the implementation of the regulatory right of a person to establish the fact. Therefore, the form of court proceedings must not be a claim, this regulatory right must be exercised on the relevant application of the person concerned of a non-claim nature. Modern legislation quite rightly does not apply the statute of limitations on the protection of rights (most scholars believe that it is a matter of protection of interests [60, p. 26-34]) when considering cases of separate proceedings, and proposals to settle such claims are unconvincing.

The problem is that the legislator sometimes unjustifiably gave a claim form to those protective relations, which by their nature did not need it at all. This approach cannot be considered successful. He does not agree with the theory that by filing a lawsuit, the material protection right is realized by its holder. In turn, the subjective right to sue can arise only after the violation of the regulatory relationship, as long as 
there is no violation - this right is absent. This is largely true of recognition requirements. For example, it is hardly possible to agree that the issue of establishing the nullity of a transaction should take place in a lawsuit. In this paper, we also pointed to the need to introduce a non-litigation mechanism for judicial recognition of rights in certain cases (for example, loss of documents).

It is considered that the list established in the commented article of the Civil code is exhaustive. Such a statement is valid only in relation to purely civil claims. However, cases where the requirements for protection of the infringed right in court are not subject to statute of limitations, may be provided by other acts, both civil law and different sectoral regulation in the case of protection of subjective rights from the offense arising from relevant relationship, has a claim form. For example, Article 238 of the Labor Code of Ukraine states that claims for payment of amounts due to the employee must be satisfied by the court without any time limit. And although this rule does not refer to the period during which a person has the right to go to court for protection, but only to the duration of the claim itself, it is clear that these time intervals are interrelated. Therefore, there is no doubt that it is a question of non-application of the statute of limitations to the specified requirements. The non-extension of the ancient legal institution to family relations is prescribed in Art. 20 of Ukrainian Family Code.

However, cases when the statute of limitations does not apply to certain protection and legal requirements, we repeat, can be determined only by law. They do not have the right to establish in bylaws, and even more so in law enforcement documents. Therefore, the position of the High Specialized Court of Ukraine for Civil and Criminal Cases should be recognized as inconsistent with the legislation of Ukraine, according to which, given that, as a general rule, a person who has carried out or is carrying out unauthorized construction of real estate does not acquire ownership , the statute of limitations on the requirements for the reconstruction of spontaneously built or under construction, residential building, annexes to it, buildings, structures or other real estate, as well as the demolition of such objects is not missed regardless of the length of time that has elapsed after completion or start of construction. The 
position of the Supreme Commercial Court of Ukraine on the non-application of the statute of limitations to negative claims should also be critically assessed. The Civil Code clearly states that, since a specific requirement is not contained in Art. 268 of this document or in another law, the statute of limitations must be applied as a general rule.

As we can see, the rules of the statute of limitations apply to the vast majority of claims arising from the violation of a person's subjective substantive law. In other words, almost all claims are settled. However, in order to calculate the duration of the substantive right to sue, it is necessary to clearly establish the starting point of the statute of limitations. In general, it is easy to do, given the fairly clear rule of Part 1 of Art. 261 of the CCU: the statute of limitations begins from the time when the person learned or could (read - had to) learn about the violation of his subjective substantive right or the identity of the violator. As a general rule, the statute of limitations begins from the time a person realizes a violation of his subjective right. This should take into account the peculiarities of the content of the protected right and the manner in which the violation affects it. Thus, according to the claims for compensation for nonpecuniary damage, the limitation period begins from the moment the suffering begins, but not before the victim realizes the causal link between the suffering he endures and the violation of his right. Therefore, it is quite logical that the legal literature is dominated by the idea that the substantive right to sue is associated primarily with the moment of violation (awareness of this fact) of regulatory law [61, p. 103]. It is from this term (taking into account the possibility of the managed person to learn about the violation or the identity of the violator) begins the statute of limitations on the relevant requirements that constitute the content of the protection law.

Thus, the four legally significant phenomena at the time of their occurrence are closely interrelated: violation of the law, awareness of this fact by the carrier, the substantive legal protection requirement and the beginning of the statute of limitations. Exceptions to the general rule on the beginning of the expiration of the statute of limitations are established by law (Part 7 of Article 261 of the Civil Code of Ukraine). It is logical that these exceptions will delay the initial period for the next period from the moment of violation. This fully corresponds to the essence of all civil doctrines: 
there is no offense, there is no substantive right to sue (protective substantive claim). Namely, this claim, only it and no other substantive or procedural subjective right, is subject to satisfaction.

However, in civil law there are sometimes legal constructions when the statute of limitations begins before or regardless of the actual violation of subjective law. For example, according to the literal interpretation of the prescription of Part 5 of Art. 261 of the Civil Code - for obligations, the term of which is not determined or determined at the time of the claim, the statute of limitations begins from the day when the creditor has the right to demand performance - we get a completely unacceptable result: the creditor receives the right to sue for these obligations at the time of the obligation. On the other hand, it is the duration of the substantive right to sue that is limited by the statute of limitations. Therefore, in these obligations, the right to sue and the statute of limitations exist regardless of the violation of subjective civil law and usually begin before it occurs. Therefore, given the absurdity of this result, even those scholars who traditionally, instead of proposing improvements to the normative rule, try to theoretically justify such a failed legislative structure, can not but note that the violation of the law with an indefinite period of implementation, in fact, occurs only after default. stated by the creditor at any time the claim [62, p. 403-404]. But for an unambiguous understanding of this fact, the content of Part 2 of Art. 530 of the CCU should be adjusted. The above claims fully apply to the negligence of the legislator in other situations. An example of an act that establishes the initial moment of the statute of limitations, regardless of what the person did not know and could not know at this time about the violation or violator, is Part 1 of Art. 862 of the CCU (rule on the beginning of the statute of limitations on the requirements for improper quality of work).

Another problem that needs attention is the difficulty in some cases of determining the initial term of the statute of limitations given the regulatory uncertainty of the moment of the offense. Therefore, the correct result can be achieved only by conducting a legal analysis of the real nature of the relationship and their temporal features. Take, for example, the legal regulation of the testator's creditor's claims against the heirs. Article 1281 of the CCU deals with the procedure and terms of 
addressing such requirements. This rule refers to the implementation of creditors during certain periods of their regulatory right - to acquire the status of creditor in respect of heirs who have inherited. In other words, the exercise of statutory (secondary) authority.

Therefore, these periods can in no way be qualified as a statute of limitations, as they do not mediate the duration of the security claim. However, the creditor of the testator is not deprived of the opportunity to protect his right in court in case of violation by the heirs. The violation in this case should be considered dissatisfaction of the heirs of the creditor's claim, filed within the prescribed period. However, the law does not specify which period should be considered appropriate to meet the creditor's regulatory requirement. Therefore, we must be guided by the general principles of reasonableness: only after non-compliance with the requirements of the heirs within a reasonable time there is a material right to sue. The statute of limitations for such claims, the possible content of which will be determined by the nature of the violation and will depend on the violated right itself, will be three years, as the law does not introduce anything other than a general term.

It should be clearly understood that the regulatory right of the creditor of the testator to require performance of the obligation from the heirs, and hence his claim to the latter in case of non-compliance with this requirement may arise only after the opening of the inheritance. This is true even if even before the death of the testator began the statute of limitations on the relevant requirements for him. Death terminates the protection and legal relationship together with the expiration of the statute of limitations. There is a new one: the participants of which are the creditor of the testator and the heirs. At the same time, they are no longer participants in a protective binding legal relationship, but in a regulatory one. It includes the secondary right of the creditor, which is exercised by committing a unilateral action within a specified time.

As we can see, according to our legislation, there is a certain diversity in the regulation of succession under these requirements. On the one hand, Art. 1218 of the $\mathrm{CCU}$ indicates that the heirs inherit all the assets and liabilities of the testator, and the legal component for this will be the death of the latter (opening of the inheritance) and 
acceptance of the inheritance. On the other hand, in accordance with the rule of Art. $1281 \mathrm{CCU}$ to acquire the status of successors to the debts of the testator requires a greater set of legal facts: in addition to the above, it is necessary to address the relevant requirements of the creditor of the testator. But, if you look more closely, the construction proposed in the last legal norm, in fact, can not be considered a successor. The fact is that the heirs in the event of a regulatory requirement within the statutory cut-off period become participants in a new regulatory relationship, the content of which they must within a reasonable time to fulfill the duty of the testator. It is to establish such a relationship and aims to exercise the creditor's secondary right. And only in the case of non-compliance within the specified reasonable period of such requirements there is a protective relationship, an element of which is the statute of limitations. At the same time, before the opening of the inheritance, the relationship between the testator and his creditor for this debt could be both regulatory and security.

However, such a cumbersome and seemingly somewhat awkward legal construction of the mechanism of satisfaction of the heirs' claims of the testator's creditor, certainly has advantages over the relevant tools used in the Russian Central Committee. According to Part 3 of Art. 1175 of the Civil Code, the creditors of the testator have the right to make claims against the heirs who accepted the inheritance, within the duration of the statute of limitations established for the relevant claims. It is easy to see that such an approach poses very great risks for the creditor and, ultimately, the heirs themselves. First, the statute of limitations for the testator may expire very shortly after the death of the testator, giving the creditor very little time to maneuver (claim), given the need to be aware of the fact of death, the circle of heirs and the amount of available inherited property. Moreover, the statute of limitations on the commented requirements is not subject to suspension, interruption and renewal. Second, the obligations between the creditor and the testator, in which the latter is the debtor, may well be of a long-term nature, and the time of performance will come, say, five years after the opening of the inheritance. By the logic of Part 3 p. 1175 of the Civil Code protection requirements, including by filing a lawsuit against the heirs, the creditor of the testator will be able to present only after they fail to fulfill the inherited 
regulatory obligation, ie at least five years. But whether the heirs will have enough money or property by then is another question.

It is also necessary to distinguish the protection requirements for heirs arising from the transfer to them by succession of duties of the testator and non-performance of the latter, from the requirements to them, which, although related to the acceptance and registration of inheritance, but not related to obligations testator. For example, there is no six-month or other period for the executor's claim to the heirs for reimbursement of expenses incurred by him in order to protect, manage and inherit the inheritance. These requirements are regulatory in nature. Their regulation involves the use of at least two temporal factors, which, unfortunately, are not defined by law. The first of them is the period of appeal to the heirs. The deadline for such notification is not set by law, so we must also use the principle of reasonableness and good faith. The second concerns the time of fulfillment of such a requirement within the regulatory relationship that has arisen between the executor of the will and the heirs. Since the legislator is also silent on this issue, we must consider this period also reasonable. Claims arising from the relevant claim arise from the failure of the heirs to fulfill their own obligation to reimburse these costs, which must be met within a reasonable time after their notification. From the moment of non-fulfillment of this obligation, the general limitation period for the relevant claims begins.

As we have already mentioned, Part 7 of Art. 261 of the CCU and the relevant articles of the civil codes of other countries provide for the possibility of starting the statute of limitations at a different time than is established by the general rule. In fact, we are talking about the introduction of a rule according to which the offense and the beginning of the statute of limitations may not coincide in time. Such a legal approach sometimes does not find a positive response among scholars. However, the argument of such objections is not always sound. For example, K. Lebedeva, criticizing the proposed rule, points out that it may lead to the fact that the right to protection exists for some time, but can not be realized due to the lack of a long-standing course, and therefore loses its meaning. existence in this period [50, p. 119]. 
It is hardly possible to agree with this. Be that as it may, the civil legislation of Ukraine, Russia and some European countries of continental law defines certain cases when, as an exception to the general rule, the statute of limitations does not begin from the time the right holder realizes the violation [63, p. 269-274]. Moreover, such a deviation in time can be quite long. It would be completely inexpedient to consider that during the period from the offense to the beginning of the statute of limitations there is a claim that cannot be realized. On the contrary, it is obviously logical to conclude that the legislator in some cases, clearly indicated by him, postponed not only the statute of limitations, but also the onset of the substantive right to sue. This is all the more important if we take into account that the moment of occurrence of the right to sue as an element of the protective relationship is connected with the moment of the offense (its realization by the right holder). This conclusion once again confirms the inseparability of the legal essence of two interrelated objective legal phenomena: the substantive right to judicial protection and the statute of limitations. The statute of limitations is the term of existence of the substantive right to sue, so the protection and legal claim can be carried out only during the statute of limitations. However, de facto situations where a person has received the right to judicial protection, but can not exercise it are quite common. And they are not related to the postponement of the statute of limitations, but to the absence of the subject's right to sue in the procedural sense (for example, in the case of mandatory application of the claim procedure).

Ukrainian legislation, as noted earlier, did not adhere to the concept of nonextension of the statute of limitations on certain claims for ongoing violation of a person's property rights, especially in the regulation of mandatory security relations. However, when calculating the initial moment of the long-standing course of claims for damages, we can conclude that the protective court claims, which arise from both absolute and binding relationships, it has the character of a number of individual courses, which continuously begin until end of violation. Each of these permanent courses has its own initial moment, each of them regulates the duration of a separate claim, different from the others. For example, if the ongoing violation of the terms of the contract (termination of uninterrupted supply of thermal energy) began on 
September 15, provided that the same daily losses of $100 \mathrm{UAH}$ the content of the claim for compensation will be UAH 100 (according to the lawsuit, which began on June 16 and will end on June 15 in three years); 100 UAH (if the course began on June 17), etc.

In three years 1095 such one-day claims will be typed. If to sum up all separate requirements on separate currents which duration at that time will be various - from three years (on the first ancient currents) to several moments (on the last), we will receive volume of the substantive legal claim. In fact, this design reflects the principle of satisfaction of claims, which describes quite well the recovery of one-time damages or damages. But that is the difference between recovering one-time damages and those incurred today in connection with an ongoing violation. If, until the latter case, the standard rule on the calculation of the statute of limitations from the date of the infringement is applied, then for the continued non-performance of the obligation, this will mean the satisfaction of the claim from the beginning of the infringement. Therefore, it is possible that some of the protection claims will remain outside the statute of limitations if the duration of the violation is more than three years (for example, if the contract for the provision of continuous services is five years).

Claims that are outside the statute of limitations, although substantiated from a material point of view, will not be subject to judicial satisfaction, as they are outside the scope of the protective claim. The temporal rule of limited retroactive effect of the requirement which is applied in the current legislation at judicial collecting of separate sanctions is not suitable for the decision of the described problem also. According to this rule, whenever a person applies to the court, the claim is satisfied only to the extent that it is calculated only for the last three years before filing the claim. Yes, according to previous Ukrainian Soviet legislation. claims for damages to health were met in the three years preceding the filing of the lawsuit. A similar rule applies to the current Russian Civil Code, moreover, some scholars believe that it most fairly reflects the actual nature of the claim in the ongoing violation.

We cannot agree with this view. This rule is almost indistinguishable from the general mechanism for calculating the statute of limitations from the beginning of the ongoing violation. After all, in one case, the claims will not include those that were 
accrued after the expiration of three years from the beginning of the offense. Otherwise - in case of extension of the duration of the violation from the total claim will be removed old (first) claims and add new ones, the course of which has just begun (satisfaction of claims for compensation for continuing damages will be carried out not from the initial moment of their occurrence, but in the opposite direction from time of presentation). However, the amount of claims actually claimed for damages or damages, despite the fact that they result from the violation, will be limited.

There is only one way to solve this issue: to make a fundamental regulatory decision, for example, of the following kind: the statute of limitations for claims for damages or damage caused by a continuing violation of a person's subjective right begins at the beginning of the violation and ends one year after. Such proposals have already been heard in civilistic literature [57, p. 219-220].

It is generally accepted that the right to go to court to consider the dispute and make a decision is not limited by the statute of limitations. This rule is enshrined in Part 2 of Art. 267 of the CCU and in fact characterizes the fact that the right to sue in the procedural sense is not expired: a person can not be denied a statement of claim in connection with the omission of the statute of limitations. The obligation of a court to accept an application for protection of a civil right or interest, regardless of the expiration of the statute of limitations, is fully consistent with the provisions of civil law on the need to protect the right if the reasons for its omission are valid. However, it is noteworthy that this interaction of the two rules may be violated under the new provision of the law on the application of the statute of limitations only on the application of a party to the dispute over its expiration (Part 3 of Article $267 \mathrm{CCU}$ ). Therefore, in a situation where the plaintiff's omission of the statute of limitations is obvious, with such a legal construction, the issue of satisfaction of claims may not arise at all when considering the case by the court.

Let's take a closer look at the commented legal tools. In Ukraine, there is currently a law under which the court has no right to deny a claim to a plaintiff who has expired the statute of limitations, if the defendant does not make a relevant statement during the trial before the decision is made. We have opposed and continue 
to strongly oppose such an approach because we believe that it is not based on the real nature of the relationship that actually takes place, moreover, it distorts one of the fundamental concepts of civilization - subjective substantive law and its content.

The rule of judicial application of the statute of limitations solely on the basis of the statement of the party to the dispute (read - the defendant) Ukraine adopted from foreign civil codifications, according to which the issue of statute of limitations is not raised by the court (Art. 1501 of Civil Code of Austria, Article 200 of the Belarusian Civil Code Article 199 of the Civil Code of the Russian Federation, etc.). A similar rule is also introduced for relations of international purchase and sale (Article 24 of the Convention on Limitation Periods in International Purchase and Sale of Goods). It is all the more annoying that the essentially incorrect legal configuration has gained international development. One could still talk about the expediency of this mechanism within the doctrine of a single ten-year statute of limitations, which was enshrined in law more than a century ago. After all, this concept was used exclusively to enforce property law, and the position of the untitled purchaser on the application of the statute of limitations was essential. As I.E. Engelman pointed out, "a ten-year term is only a minimum, with the expiration of which the ancient owner has the opportunity to show his decision to use the statute of limitations in one way or another. Until it is revealed in some form, the statute of limitations cannot carry out its legal effect, because there is no condition for that - the manifestation of the will of the owner" [62, p. 137]. Nowadays, when the institutions of statute of limitations and statutes of limitations are regulated by different legal instruments and are not related to each other, the rule of mandatory reference to the statute of limitations is, at least, unbalanced.

Despite the imperfection and inconvenience of the commented mechanism itself, which, in the end, could be eliminated by law, it has such defects that cannot be corrected or changed. It is about its influence on the general theoretical substantiation of the legal nature of civil material terms and their significance for the exercise of subjective rights and obligations. Civil law term is a period of time, with the onset or expiration of which occur legally significant phenomena. In this case, the term is an element of the subjective substantive law of the person, and its expiration, as well as 
the exhaustion of other characteristics of the latter (in terms of scope of authority, behavior, etc.) leads to the termination of the subjective right. This has already been mentioned in more detail in our previous works [57] and in this paper. For example, the beginning of the statute of limitations ensures that a person has a protective power - a claim, and the end of its course together with the fact of failure to file a lawsuit means the termination of the protection right to a claim.

The innovation of the current civil law not only eliminated the importance of the statute of limitations as the limits of the existence of this protection right, it made it dependent on the implementation of the parties' subjective right to a statement on the expiration of the statute of limitations. This right, as well as the right of the party to the dispute to make any other statements, is procedural, as it cannot be exercised outside the process. Therefore, the existence of a material power of judicial protection depends on the fact of realization or non-realization of a certain procedural power. In other words, if the process has not begun, the claim has an indefinite duration.

For example, a person does not apply to the court for thirty years. It continues to have a substantive right to sue, as its termination is linked to an action that can only be taken in the course of the proceedings. Since the expiration of the statute of limitations does not in itself affect the effectiveness of the claim, and the statement of its termination can be made only in the process, we must consider the substantive right to sue existing throughout the period from its occurrence (offense) to at least presentation I will sue. This means that the statute of limitations does not in fact affect the viability of the claim, for which there is only a certain probability of declaring it lost in the future. Agree, the right holder has no reason to consider his right to judicial protection revoked, although, on the other hand, he can not be sure at all times after the end of the statute of limitations as to whether he has the right to sue. After all, the court's decision to lose the right to sue will be made "retrospectively." Such an approach is unlikely to meet the social needs for stability of civil relations, which were the basis for the introduction of the ancient institution.

As we have just noted, the procedural right to sue is not subject to the statute of limitations, while absolutely all doctrinal authorities are convinced that the material 
claims are outdated. However, under the new conditions, the commented norm begins to be interpreted as a rule about the indefiniteness and substantive right to sue. Because this is the rule of law, which states the obligation to exercise the right, which has ceased if the debtor for some reason forgot or could not inform the creditor and the court about the fact of its invalidity. The duration of the protection power is no longer limited by the regulatory period, because it is possible that the creditor, having filed a lawsuit outside the statute of limitations and having no valid reasons for its restoration, will still receive judicial protection in the absence of the defendant's statement of claim. statute of limitations to the stated requirements. In fact, the defendant now has the right not only to determine the fate of the litigation after the statute of limitations, but also to set a deadline for the right to sue, which will depend on his application. In modern conditions, as we see, the right to sue in the material sense not only does not end after the expiration of the statute of limitations, but may even exist forever, because the relevant statement is not made by the party to the dispute.

The introduction of the rule on the binding nature of the statement of the party in the dispute for the application of the statute of limitations by the court gave a new color to the judicial analysis of the objections against this statement. Now these objections are submitted only after receiving the said application, and even the request to renew the statute of limitations if it is clearly omitted when filing a lawsuit has lost its meaning. During the consideration of the dispute the plaintiff may refute the fact stated in the statement of the defendant the expiration of the statute of limitations, taking into account certain circumstances that led to the suspension, interruption of its course or postponement of the initial term. But the need to investigate these circumstances arises only when there is reason to believe that the statute of limitations has expired at the time of filing the lawsuit. Of course, the necessary arguments must be provided by the plaintiff, who is interested in the effectiveness of his substantive right to judicial protection. But the law does not define these powers as exclusive.

Unlike the judicial application of the statute of limitations, which is carried out only at the request of the party to the dispute, the issue of its refutation can be resolved at the initiative of the court. Therefore, we believe that if the defendant claims that the 
statute of limitations applies, the court is obliged to give it a legal assessment and thus investigate the issue of statute of limitations, even if the plaintiff does not specifically request it. For example, if the defendant has improperly substantiated his application for the application of the statute of limitations (for example, he has given an incorrect arithmetic calculation or an erroneous date for its commencement, etc.), the jurisdiction must disregard the circumstances denying the statute of limitations. In fact, minor changes have taken place in this procedure - instead of the need to prove to the court the validity of the reasons for missing the statute of limitations or other circumstances proving its non-expiration, as before, such a duty is now imposed on the plaintiff only if statements from the defendant. In this, some researchers see a manifestation of the principle of dispositiveness. The application of the statute of limitations only on the application of the defendant, they consider a manifestation of this principle in the process. We cannot agree with this concept. The law gives the defendant's application for the expiration of the statute of limitations on the status claims of any other fact, which substantiates the plaintiff's claims and objections against them: because they are not proved by the parties, these circumstances are irrelevant to the case. After all, the court has the right only to evaluate the arguments provided by the parties, and not to collect them. Therefore, when the party who has the opportunity to object to the claim with reference to the statute of limitations does not do so, such an argument, even if it is indisputable, is lost. This position is substantiated in scientific publications as a dispositive rule on the provision of evidence by the parties involved in the case. The fact is that the application of this principle in this situation can not be supported.

Because, first, in this case we are not talking about gathering evidence, but about their evaluation. After all, as you know, any other circumstances of the case, other than the facts proving the omission of the statute of limitations, even if they are not claimed by the party, can be clarified by the jurisdiction. Secondly, the party's reference to the statute of limitations is fundamentally different from other evidence provided by it in resolving the dispute. Dispositiveness is the free choice by the parties to the process of evidence that they use to substantiate their claims or objections. However, as G. Gordienko rightly points out, the statute of limitations is not evidence in the case, the 
evidence can be any factual evidence of the expiration of the statute of limitations [64, p. 50]. To assess the course of the statute of limitations, a set of arguments is sufficient to establish the facts of the legal relationship, its violation by the obligated person, etc. Therefore, when the defendant does not even refer to the statute of limitations when denying the claims, from the content of the evidence provided by him and the other party, it is possible to accurately establish the expiration of the statute of limitations or not. In considering the case, the court must carefully examine the evidence provided by the parties. This means that the jurisdiction must analyze them comprehensively and come to conclusions that may not have been stated in the claims and objections of the parties.

Establishing the initial term of the substantive right to sue, of course, has a decisive influence on the calculation of its duration. It is during this period that the creditor's secondary claim can be realized. If the law enforcement authority establishes the fact of omission of the statute of limitations, it must refuse to satisfy the claims with reference to this circumstance. Therefore, the thesis has become widespread that the refusal of the plaintiff to satisfy his claims in case of omission of the statute of limitations should be motivated by the law enforcement body by the loss of the substantive right to sue and does not require other additional argumentation [65, p. 77].

In practice, we hear that this approach does not allow to achieve the right result, there is a long-standing controversy in the literature about whether in this case the court should clarify other circumstances relevant to the case and reflect this in the decision. In particular, it concerns the obligation to investigate the question of whether the plaintiff has a subjective substantive right, for the protection of which he seeks, as well as the question of its violation by the defendant. Finally, there is also the opinion that the analysis of the material validity of the claim can be carried out by the court only when it is stated in the petition of the defendant [66, p. 7, 46]. For participants in a civil dispute can be very important not only the result of its trial, but also the legal grounds that led to it. Therefore, the supporters of this approach believe that the decision of the court to dismiss the claim in connection with the omission of the statute of limitations by the right holder does not further resolve the question of the validity of his claims. 
After all, whether the right claimed by the plaintiff belongs to him depends on the possibility of its further implementation, for example, by voluntary performance of the obligation by the debtor or the legality of further assignment of this right, and so on. Refusal to collect a non-existent debt on the grounds of omission of the statute of limitations may entail illegal crediting by the debtor of accounts payable to gross income. Therefore, it is stated that, despite the omission of the statute of limitations, the law enforcement authority must clarify the validity and validity of the claim and indicate its conclusions in this regard in the court decision.

In our opinion, the formulated problem is largely artificial. The court's refusal to satisfy the claim due to the plaintiff's omission of the statute of limitations means that the law enforcement body, having analyzed the essence of the relationship between the parties, established the plaintiff's right to sue in the material sense, but this right has expired and is not enforceable. In other words, the court confirms that the violated regulatory right belongs to the person and the fact of its violation by the defendant, but refuses to defend it. If this is not the case, and the plaintiff does not have the subjective right indicated by him in the claim, or it has not been violated in the manner he indicates, or this right has not been violated by the defendant, the statute of limitations for these specific claims did not begin. therefore, it could not end [67, p. 49]. There is no offense (as established by the court) - the statute of limitations has not begun. Therefore, the claims are not substantiated, the court must refuse to satisfy them on these grounds, and the statute of limitations in this case did not even begin its course.

On the other hand, since the right to sue does not exhaust all the creditor's powers under the protection relationship, but is only an integral part of them, after the claim is settled, the latter has the right to claim the debtor, although such a right is no longer secured by legal capacity. Thus, we must conclude that the right to protection does not end with the expiration of the statute of limitations and even with the refusal of the court to protect it due to the omission of the statute of limitations. Moreover, the court's decision to apply the statute of limitations to certain claims indicates that the right belongs to the creditor and the debtor has a corresponding obligation, simply the 
possibility of enforcement of this right has expired with the expiration of the period for recourse to court.

Of course, protection of the violated right in court can also take place in case of missing the statute of limitations. We are currently talking about the restoration of the statute of limitations by the court (Part 5 of Article 267 of the CCU). It will take place in the presence of such a precondition as the seriousness of the reasons for its omission. The legislation does not specify and cannot specify an exclusive list of such circumstances, so the court must determine which reasons are valid and how they affect the missed deadline and the possibility of restoring the statute of limitations. But in any case, when deciding on the restoration of the statute of limitations, the law enforcement body must establish that the right belongs to the plaintiff and the facts of its violation by the defendant. Only if the plaintiff has a substantive legal protection claim against the defendant, this claim will be satisfied, and it is possible to talk about the statute of limitations and, accordingly, its omission and restoration. It follows from the above that the court, which restored the statute of limitations, in fact decided the merits of the claim.

Thus, the question explored in this paper is very relevant. The statute of limitations as a civil law institution, of course, refers to the legal tools that are designed to regulate the protective legal relationship. Indeed, the regulatory power of the bearer does not have coercive properties, no matter how they claim otherwise. However, the research conducted in this paper also allows us to reject another extreme that is sometimes found in the literature - the identification of claims with protective subjective law. The substantive right to sue is only one of the elements of the protection law that arises in a person in the event of an offense. The right holder may exercise the subjective protection right not only by applying for state coercion, but also by other non-judicial means provided by law and generally accepted customs.

It is quite obvious that the establishment of certain time limits for the exercise of the right to protection with the participation of jurisdictional bodies mediates the public interest. It is in society's interest for civil relations to be orderly and defined. Therefore, by encouraging the subject of the right to exercise it for a certain period of 
time under the threat of termination, society achieves the satisfaction of its public interest, bringing certainty to the private-legal relations of participants in civil circulation. Taking into account mainly imperative mechanisms of law-making, such an order is expedient and has been applied in determining the time for exercising the protection and legal authority of a person - the statute of limitations. Since material relations are carried out in a state-organized space, the specifics of legal regulation in this case is to organize a threefold interaction of state, society and the individual, taking into account the interests of each.

If the question of the need to settle the claim, as a rule, does not cause objections, the problems of the effectiveness of the current legal mechanism continue to be very relevant. The fact is that the ancient institution, due to the mentality of the participants in civil proceedings, is probably the most used in resolving specific disputes by jurisdictions. Therefore, its social significance is difficult to overestimate. Unfortunately, we must state the great heterogeneity of judicial application of the same articles of Chapter 19 of the Civil Code of Ukraine. This is to some extent facilitated by the unsuccessful construction of some norms that allow unjustifiably expanded interpretation or even contradict the essence of factual relations, which require legal regulation. It is easy to see that some novelties of the current legislation are in fact a step backwards, they do not contribute to achieving exactly the main goal, which was the basis for the introduction of the ancient institution - to gain certainty in the relationship of participants in civil circulation. As a result, a number of articles of Chapter 19 of the CCU are either not applied by the courts at all (Part 4 of Article 261 of the CCU), or are applied contrary to their content (Part 5 of Article 261 of the CCU) or purpose (Part 1 of Article 264 of the CCU). 


\section{SECTION 3. CRIMINAL AND CRIMINAL-EXECUTIVE LAW}

DOI 10.46299/ISG.2021.MONO.LEGAL.II-67-79

\section{1 Окремі питання кримінально-правової охорони власності від} незаконного вилучення 3 житла, приміщення чи іншого володіння особи в праві України, окремих держав СС, Великої Британії та США

Однією $з$ типових ознак складів низки кримінальних правопорушень, передбачених в статтях Особливої частини Кримінального кодексу України від 5.04.2001 року[68] (далі - КК України), є ознака «проникнення» у житло, приміщення, сховище, інше володіння особи.

Загальний зміст цієї ознаки цілком очевидно дозволяє розглядати їі використання в нормах КК України як кримінально-правовий засіб охорони, не лише власності, яка перебуває у такому житлі чи іншому володінні особи, а й одного $з$ фундаментальних прав людини, гарантованого в ст.30 Конституції України, «недоторканність житла чи іншого володіння особи». Разом 3 тим, ефективність цього кримінально-правового інструменту безпосередньо обумовлюється його конкретним змістом, який (зміст) встановлюється шляхом правозастосовного тлумачення терміну «проникнення».

Правозастосовне тлумачення змісту терміну «проникнення» обумовило виникнення у правозастосуванні двох: ширшого і вужчого підходів до розуміння змісту ознаки «проникнення у житло, приміщення, сховище». У свою чергу, існування цих двох різних підходів обумовило необхідність врегулювання цієї ситуації Великою Палатою Верховного Суду, яка користуючись повноваженням, передбаченим в п.1 ч.2 ст.45 Закону України «Про судоустрій та статус суддів» від 02.06.2016 р.[69], прийняла у касаційному порядку постанову від 18.04.2018 p. $з$ метою забезпечення однакового застосування судами норм права [70]. Підхід до тлумачення ознаки «проникнення», сприйнятий Великою Палатою Верховного Суду, становить собою вужче розуміння терміну «проникнення», тобто завдяки цьому рішенню Великої Палати за межами кримінально-правової оцінки саме як вчинення кримінального правопорушення «з проникненням» залишилась суттєва частина ситуацій вчинення кримінальних правопорушень на 
території володіння особи. Такий підхід, на нашу думку, потребує критичного осмислення i визначення способів вдосконалення понятійного i термінологічного апарату КК України, які б забезпечували відповідність законодавчої кримінально-правової оцінки ступеню суспільної небезпеки[71, с.22], яким характеризуються ситуації викрадення власності, яка знаходиться на території певного володіння особи.

Питання кримінальної відповідальності за кримінальні правопорушення проти власності були і залишаються предметом дослідження в наукових працях багатьох вчених, серед яких П.П. Андрушко, Д.П. Альошина, О.О. Дудоров, Д.О. Калмиков, Д.В. Каменський, П.С. Матишевський, О.Р. Марін, В.О. Навроцький та багато інших вчених. Разом з тим, поза увагою вчених залишається науковий аналіз виправданості позиції Великої Палати Верховного Суду, викладеної у вказаній вище іiі постанові від 18.04.2018 р., щодо розуміння змістовних характеристик ознаки «проникнення» й визначення з урахуванням цієї позиції та відповідного зарубіжного досвіду, насамперед, провідних держав світу, можливих варіантів заміни цієї ознаки кваліфікованих складів злочинів на більш ефективну модель охорони власності, яка (власність) зберігається у володінні особи.

Проведене нами під таким кутом зору дослідження дозволяє констатувати, що кримінально-правові гарантії охорони власності, яка зберігається у житлі чи іншому володінні особи, мають тривалу традицію існування в правовій системі України. Зокрема, відповідні положення були передбачені в Кримінальному кодексі України 1960 року [72]: ч.3 ст. 15, ч.3 ст.81, ч.3 ст.82, ч.2 ст.86, ч.3 ст.140, ч. 3 ст.141, ч.3 ст.142 і передбачені в чинному КК України: ч.5 ст.36, ч.1 ст.162, ч. 3 ст. 185 , ч. 3 ст. 186, ч. 3 ст. 187 , ч. 2 ст. 289 КК, правда слід відмітити, що в ч.5 ст.36 КК України відповідна ознака в межах інституту необхідної оборони позначена терміном «вторгнення», а не «проникнення».

Природньо, що протягом усього періоду чинності КК України зміст ознаки «проникнення» є об'єктом наукового та правозастосовного тлумачення. Для прикладу, П.С. Матишевський пропонував таке розуміння змісту цієї ознаки: 
«проникнення - це таємне, відкрите чи із застосуванням насильства вторгнення у житло, приміщення, сховище з метою вчинення крадіжки, грабежу чи розбою. Проникнення пов’язане з доступом до майна таємно, шляхом докладання зусиль чи насильства (фізичного або психічного), обману, підкупу або недозволеного входу через відкриті двері. Докладання зусиль 3 метою проникнення у приміщення чи інше сховище може полягати у застосуванні винним технічних засобів, пошкодженні сховища або охоронних засобів...Не може розглядатися за ознакою проникнення ...викрадення майна особою, яка має за своїм службовим становищем або у зв'язку з роботою, яку вона виконує, доступ у таке приміщення...Не може кваліфікуватися як проникнення у приміщення викрадення товару покупцем або сторонньою особою з магазину у ті години, коли він працює»[73, с.346-347].

Подібний підхід закріплений і у постанові Пленуму Верховного Суду України від 6.11.2009 р. №10 «Про судову практику у справах про злочини проти власності»: «22. ... Під проникненням у житло, інше приміщення чи сховище слід розуміти незаконне вторгнення до них будь-яким способом (iз застосуванням засобів подолання перешкод або без їх використання; шляхом обману; з використанням підроблених документів тощо або за допомогою інших засобів), який дає змогу винній особі викрасти майно без входу до житла, іншого приміщення чи сховища. Вирішуючи питання про наявність у діях винної особи названої кваліфікуючої ознаки суди повинні з'ясовувати, з якою метою особа опинилась у житлі, іншому приміщенні чи сховищі та коли саме в неї виник умисел на заволодіння майном. Викрадення майна не можна розглядати за ознакою проникнення в житло або інше приміщення чи сховище, якщо умисел на викрадення майна у особи виник під час перебування в цьому приміщенні.»[74].

Підхід, закріплений в постанові, $є$ загальноприйнятим і в доктрині кримінального права. Для прикладу, вчені Д.О. Калмиков та Д.В. Каменський, розкривають зміст ознаки «проникнення» саме з посиланням на постанову ПВС України від 6.11.2009 р. №10 і зазначають, що під проникненням до житла, 
приміщення, сховища - «слід розуміти незаконне вторгнення до них будь-яким способом ..., який дає змогу винній особі викрасти майно без входу до житла, іншого приміщення чи сховища». При цьому автори підкреслюють, що ознака проникнення відсутня, якщо умисел на викрадення майна виник вже під час перебування в приміщенні [75, с.368].

Разом з тим, співпадіння підходів до розуміння загального змісту ознаки «проникнення» не змогло запобігти виникненню в правозастосуванні двох відмінних підходів до розуміння змісту окремих деталей в ознаці «проникнення». Так, розглянувши кримінальну справу в порядку перегляду судових рішень у зв'язку 3 неоднаковим застосуванням судом касаційної інстанції одних і тих самих норм кримінального закону щодо подібних суспільно небезпечних діянь, яке потягло ухвалення різних за змістом судових рішень, Верховний Суд України в постанові від 15.11.2012 р. №5-15кс12 сформулював власну позицію щодо змісту ознаки «проникнення» в складі злочину розбій: «Нормативне визначення ознак аналізованого складу злочину не містить визначальних (відмежувальних) ознак розуміння поняття «проникнення». У диспозиції частини третьої статті 187 Кримінального кодексу України немає прямої вказівки на незаконність проникнення в приміщення, принаймні такої, яка встановлена у статті 162 цього Кодексу, якою передбачено кримінальну відповідальність за незаконне проникнення до житла чи до іншого володіння. Тому зміст цього поняття належить виводити 3 правової природи конститутивних (визначальних) ознак складу злочину у взаємозв'язку та 3 урахуванням правозастосовної судової практики. Логіко-граматичне тлумачення формулювання (словосполучення) «розбій, поєднаний 3 проникненням у приміщення», дає підстави вважати, що під проникненням до будь-якого приміщення слід розуміти: а) фізичне входження, потрапляння до нього 3 метою заволодіння майном, що знаходиться в ньому; б) доступ до майна, що знаходиться в приміщенні, будь-яким способом (без фізичного входження до нього), який дає змогу заволодіти таким майном, вилучити його із приміщення. Якщо суб'єкт злочину поставив собі за мету заволодіти майном, певного виду 
(якості, значення тощо), місце знаходження якого зумовлює вибір конкретного способу посягання, реалізація якого передбачає входження чи потрапляння в приміщення, незважаючи на режим доступу до нього (вільний/заборонений), то фізичне опинення в такому приміщенні з означеною ціллю є незаконним, а 3 вчиненням наступних дій iз застосуванням насильства чи погроз його застосування з метою заволодіння майном має кваліфікуватися як розбій, поєднаний з проникненням у приміщення. Наприклад, намір особи заволодіти грошима з відділення банку чи якимсь майном із іншого приміщення, умислом якої на початку виконання злочинної поведінки приміщення відділення банку чи інше приміщення в цілому сприймалося як місце знаходження майна, а насильницьке вторгнення в приміщення, незалежно від режиму доступу до нього, охоплювалось як дія.»[76] .

Однак, Великою Палатою Верховного Суду у вказаній вище постанові від 18.04.2018 р. у справі №569/1111/16-к здійснено відхід від правового висновку, викладеного Верховним Судом України у постанові від 15.11.2012 p. Зокрема, у вказаній в постанові від 18.04.2018 Великої Палати Верховного Суду зазначено таке:

«26...розбій, поєднаний з проникненням у житло, інше приміщення чи сховище, об'єднує в собі напад з метою заволодіння чужим майном, поєднаний iз насильством, небезпечним для життя чи здоров'я особи, яка зазнала нападу, або $з$ погрозою застосування такого насильства (ч. 1 ст. 187 КК України) та незаконне проникнення до житла чи до іншого володіння особи (ч. 1 ст. 162 KK

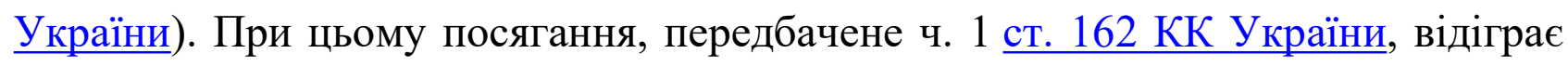
роль ознаки, що створює кваліфікований склад розбою. 27. Хоча в диспозиції ч. 3 ст. 187 КК України й немає, як у ст. 162 КК України, вказівки на незаконність проникнення в приміщення, проте це випливає із сутності та завдань закону України про кримінальну відповідальність, адже КК України визначає, які суспільно небезпечні діяння є злочинами та які покарання застосовуються до осіб, що їх вчинили. Отже, правомірні та законні дії особи не можуть вважатися суспільно небезпечним, винним діянням (злочином) i тим більше не можуть 
вважатись ознакою, яка утворює кваліфікований склад злочину, що обумовлює визначення більш суворої міри покарання. 28. Вирішальним при визначенні законності/незаконності входження (потрапляння) особи у відповідне приміщення або перебування в ньому під час вчинення розбою, $є$ режим доступу до об'єкта (вільний/обмежений). 29. Відповідно, наявність режиму вільного доступу до приміщення свідчить про законність входження (потрапляння) особи у відповідне приміщення та правомірне ії̈ перебування там, а отже, виключається інкримінування кваліфікуючої ознаки «проникнення», навіть якщо особа потрапила в приміщення з умислом заволодіти чужим майном.» [70].

Таким чином, в якості орієнтиру для забезпечення однакового застосування судами норм права Велика Палата Верховного Суду обрала підхід, який звузив межі можливого застосування норм КК, де передбачена ознака «проникнення» до житла, приміщення, сховища, вклавши у зміст цієї ознаки як невід’ємну частину «незаконність» потрапляння особи до такого місця знаходження предмету кримінального правопорушення.

На нашу думку, такий підхід не є безспірним, оскільки має як позитивні сторони, так і суттєві вади.

По-перше, мовне значення терміну «проникнення» не зводиться до характеристики виключно незаконних дій. Для прикладу, в Академічному тлумачному Словнику української мови щодо терміну «проникнення» вказано: «Наше відділення одержало завдання охороняти одну з вулиць на випадок проникнення ворожих автоматників ...; ... Проникнення ... людини в космос $\mathrm{i}$ тривале в ньому перебування — це своєрідний вінець досягнень ... науки, свідчення іiі високого зльоту ...; Тільки глибоке проникнення митця в сутність величного труда і боротьби народу за побудову комунізму дає йому творчу наснагу, допомагає повніше осмислити й емоційно відчути неповторну красу сучасності і відтворити іiі в хвилюючих образах ...» [77, с.243]. Цілком очевидно, що наведені приклади вживання цього терміну не дозволяють звести його зміст до позначення виключно незаконної дії. 
По-друге, в чинному законодавстві термін «проникнення» вживається як самостійно, так і в поєднанні з вказівкою на незаконний характер цих дій: - п.2 розділу 1 Зводу відомостей, що становлять державну таємницю, затвердженого наказом Центрального управління Служби безпеки України №383 від 23.12.2020 р.: «фізичний захист - сукупність технічних i організаційних заходів, спрямованих на виявлення і припинення спроб несанкціонованого проникнення на територію об’єкта, у його життєвоважливі зони;» [78], - Закон України «Про Національну поліцію» від 2.07.2015 р.: ст.31 «1.Поліція може застосовувати такі превентивні заходи: ...7) проникнення до житла чи іншого володіння особи...», ст.38 «1. Поліція може проникнути до житла чи іншого володіння особи без вмотивованого рішення суду лише в невідкладних випадках, пов’язаних із: 1) рятуванням життя людей та цінного майна під час надзвичайних ситуацій; 2) безпосереднім переслідуванням осіб, підозрюваних у вчиненні кримінального правопорушення; 3) припиненням злочину, що загрожує життю осіб, які знаходяться в житлі або іншому володінні.»[79], - Кримінальний процесуальний кодекс України від 13.04 .2012 р. (далі - КПК): ст.13: «1. Не допускається проникнення до житла чи до іншого володіння особи, проведення в них огляду чи обшуку інакше як за вмотивованим судовим рішенням, крім випадків, передбачених цим Кодексом.», ст.233: «1. Ніхто не має права проникнути до житла чи іншого володіння особи з будь-якою метою, інакше як лише за добровільною згодою особи, яка ними володіє, або на підставі ухвали слідчого судді, крім випадків, установлених частиною третьою цієї статті...3. Слідчий, дізнавач, прокурор має право до постановлення ухвали слідчого судді увійти до житла чи іншого володіння особи лише у невідкладних випадках, пов'язаних із врятуванням життя людей та майна чи з безпосереднім переслідуванням осіб, які підозрюються у вчиненні кримінального правопорушення.»[80]. Отже, чинне законодавство або містить окремий словесний припис про незаконність проникнення, або як це має місце в КПК, незаконність проникнення визначає конкретним змістом порушення порядку проникнення, тому в ч.1 ст.233 КПК термін «проникнення» вживається як на позначення дій, вчинених зі згоди особи, 
яка володіє житлом, так і на позначення дій, вчинених без згоди такої особи. Однак, в жодному випадку законодавство не містить ознаку незаконності як невід’ємну ознаку змісту самого «проникнення». Вочевидь 3 цього виходив законодавець й формулюючи положення КК України, де в ст.162 вказав окремо на незаконність проникнення, а в низці інших статей такої вказівки не робив, на що звертає увагу й Велика Палата Верховного Суду при тлумаченні змісту ознаки «проникнення» в ст.187 КК України.

По-третє, обмеження змісту ознаки «проникнення» лише випадками незаконного входження (потрапляння) винного до житла, приміщення, сховища видається недоцільним. Так, ступінь суспільної небезпеки заволодіння певною річчю шляхом розбою, вчиненого в приміщенні до якого винна особа зайшла скориставшись, наприклад, режимом робочого часу магазину, є вищим ніж ступінь небезпечності заволодіння тією самою річчю шляхом розбою, але вчиненого на вулиці. Зокрема, цілком очевидно, що суб’єктивна характеристика вчинення розбою в приміщенні містить в собі усвідомлене порушення винною особою низки моральних заборон, пов'язаних і усвідомленням недоторканості речей, які знаходяться в приміщенні іншої особи, а також усвідомлення складності вчинення розбійного нападу в приміщенні через обмеженість простору, наявність фізичних перешкод тощо.

Усі наведені аргументи демонструють недоцільність введення ознаки незаконності в якості змістовної характеристики ознаки «проникнення» як в складах кримінальних правопорушень проти власності, так й інших, без окремого припису про це в нормі КК. Однак, оскільки таке обмеження змісту ознаки «проникнення» впровадила Велика Палата Верховного Суду, використавши своє законне повноваження, i, визначивши описаний вище підхід як обов’ язковий для правозастосування, відповідно має застосовуватися вузьке розуміння змісту «проникнення».

Разом 3 тим, сформульований Великою Палатою Верховного Суду підхід становить собою лише результат до певної міри системного тлумачення понятійного апарату КК України і наявність цього підходу не означає, що 
проблема належного врахування ступеню суспільної небезпечності незаконного заволодіння чужим майном, яке зберігалося у певному приміщенні: житло, нежитлове приміщення тощо, повністю вирішена, навпаки, відповідні правові інструменти потребують подальшого вдосконалення аби відповідати реальним потребам кримінально-правової охорони.

В ракурсі досліджуваного питання цікавим і доцільним для врахування $€$ відповідний зарубіжний досвід криміналізації незаконного заволодіння чужим майном, яке зберігалося у певному приміщенні. Для його ілюстрації наведемо кілька нормативних актів різних держав про кримінальну відповідальність за такого типу дії.

В Кримінальному кодексі Федеративної Республіки Німеччина від 15.05.1871 р. в редакції Акту Парламенту від 13.11.1998 р.[81] (далі - КК ФРН) встановлена відповідальність окремо за: незаконне входження до чужого приміщення, незаконне заволодіння майном, що знаходиться в приміщенні, при чому диференційована відповідальність за заволодіння майном, що знаходиться в житлі особи: крадіжка 3 проникненням (§243 (1)1.) та крадіжка 3 проникненням в житло (§244 (1)3.), а саме:

- «§123: (1). Будь-хто, хто незаконно входить у житло, комерційну нерухомість або інше закрите приміщення особи, або до закритого приміщення, яке використовується публічною службою або транспортною службою, або будь-хто, хто перебуває в такому приміщенні без дозволу і не залишає його на вимогу уповноваженої особи, ...(переклад з англ. мови мій - М.П. Куцевич)»,

- «§243: (1) В особливо серйозних випадках крадіжка карається ув'язненням на строк від 3 місяців до 10 років. Особливо серйозні випадки мають місце, коли порушник: 1. 3 метою вчинення правопорушення вривається або входить до будівлі, приміщення, яке використовується публічною службою або бізнесом або вторгається 3 допомогою підробленого ключа чи іншого інструменту, який, зазвичай, не використовується для отримання доступу, або переховується в кімнаті (переклад з англ. мови мій - М.П. Куцевич)», 
- «§244: (1). Будь-хто, хто ...3. вчиняє крадіжку, для вчинення якої вривається або входить до житла або вторгається 3 допомогою підробленого ключа чи іншого інструменту, який, зазвичай, не використовується для отримання доступу, або переховується в житлі (переклад з англ. мови мій - М.П. Куцевич)».

В Кримінальному кодексі Франції від 22.07 .1992 р.[82] (далі - КК Франції) передбачена відповідальність за крадіжку з житла чи іншого володіння особи, а саме:

- «ч.1 ст.311-4: Крадіжка ...: 6. Якщо вона вчинена в приміщенні, яке використовується як житло, або в приміщенні, яке використовується або призначене для зберігання грошових коштів, цінних паперів, товарів або обладнання шляхом отримання доступу до таких приміщень 3 допомогою обману, із подоланням перешкод або влізанням.(переклад з англ. мови мій - М.П. Куцевич)»,

- «Ст.132-74: Влізання утворює дію у формі проникнення в будь-яке місце або через огорожу, або через отвір не призначені для входу. (переклад з англ. мови мій - М.П. Куцевич)».

В Акті Парламенту Великої Британії «Про крадіжку» 1968 р.[83] (далі Акт «Про крадіжку» ВБ) встановлено відповідальність за проникнення з наміром вчинити злочин («Burglary»), а саме:

- «ст.9: (1) Особа винна у проникненні з наміром вчинити злочин якщо:

(а) вона входить до будь-якої будівлі або частини будівлі без дозволу та 3 наміром вчинити порушення, вказане в частині (2) цієї статті нижче; або

(b) увійшовши до будь-якої будівлі або частини будівлі без дозволу вона викрадає або робить спробу викрасти будь-що в будівлі або у відповідній частині будівлі або завдає чи робить спробу завдати будь-якій особі в цій будівлі будьяку серйозну шкоду здоров’ю.

(2) Порушення, про яке йдеться в частині (1)(a) цієї статті вище становить собою викрадення будь-чого в будівлі або чистині будівлі, завдання будь-якій особі в цій будівлі будь-якої серйозної шкоди здоров’ю, а також незаконне 
пошкодження будівлі або будь-чого всередині будівлі. (переклад з англ. мови мій - М.П. Куцевич)».

В Кримінальному кодексі штату Нью-Йорк 1965 р.[84] (далі - КК штату Нью-Йорк) встановлена відповідальність за три типи потрапляння в приміщення 3 метою вчинення злочину («Burglary»), а саме:

«\$140.20 «Берглері третього ступеню»: «Особа винна у Берглері ІІІ ступеню, якщо вона свідомо потрапляє в приміщення або незаконно залишається в ньому 3 наміром вчинити там злочин. (переклад з англ. мови мій - М.П. Куцевич)»,

«§ 140.25 «Берглері другого ступеню»: «Особа винна у Берглері ІІ ступеню, якщо вона свідомо потрапляє в приміщення або незаконно залишається в ньому 3 наміром вчинити там злочин та якщо:

1. Здійснюючи вхід або перебуваючи в приміщенні або перебуваючи в безпосередньому польоті від цього приміщення, вона або інша особа, яка $є$ співучасником злочину:

(а) озброєна вибухівкою або іншою смертоносною зброєю; або

(b) завдає фізичної шкоди будь-якій іншій особі, яка не є співучасником злочину; або

(c) використовує або погрожує негайно використати небезпечний інструмент; або

(d) демонструє те, що здається пістолетом, револьвером, гвинтівкою, рушницею, кулеметом або іншою вогнепальною зброєю; або

2. Приміщення використовується як житло. (переклад з англ. мови мій М.П. Куцевич)»,

2. «§ 140.30 «Берглері першого ступеню»: «Особа винна в Берглері першого ступеню, якщо вона свідомо потрапляє в житло або незаконно залишається в ньому з наміром вчинити там злочин, та, якщо здійснюючи вхід або перебуваючи в житлі або перебуваючи в безпосередньому польоті від цього житла, вона або інша особа, яка є співучасником злочину:

1. озброєна вибухівкою або іншою смертоносною зброєю; або 
2. завдає фізичної шкоди будь-якій іншій особі, яка не є співучасником злочину; або

3. використовує або погрожує негайно використати небезпечний інструмент; або...».

Проведене дослідження дозволяє констатувати, що описані вище вади існуючого в праві України підходу до кримінально-правової охорони власності, яка знаходиться в житлі чи іншому володінні особи, обумовлені, вочевидь, невдалою конструкцією кваліфікованого складу відповідних злочинів, де законодавцем використана формула «назва діяння (крадіжка, грабіж, розбій тощо) поєднане 3 проникненням», в якій саме термін «проникнення» орієнтує на необхідність встановлення його самостійного змісту, який Великою Палатою Верховного Суду у вказаному вище судовому рішенні зведений лише до випадків незаконного потрапляння в житло чи інше володіння особи. Однак такий підхід, з урахуванням наведених аргументів та підходів, передбачених в зарубіжному законодавстві, цілком очевидно, слід змінити, зокрема, відповідні ознаки кваліфікованих складів злочинів, де використовується формула «діяння поєднане з проникненням» доцільно замінити на іншу формулу, а саме «діяння (крадіжка, грабіж, розбій тощо) майна, яке знаходиться в житлі чи іншому володінні особи».

Впровадження такого підходу доцільне оскільки:

1) забезпечується точна кримінально-правова оцінка ступеню суспільної небезпеки незаконного заволодіння чужим майно (крадіжки, грабежу, розбою тощо) вчиненого шляхом вилучення майна з житла, приміщення, сховища, який $\epsilon$ вищим ніж той самий вид незаконного заволодіння чужим майном, вчинений в іншому місці, очевидно, що перше вказане діяння повинно каратися суворіше;

2) термін «проникнення» навіть не у зв'язку з його використанням в якості кваліфікуючої ознаки в ряді складів злочинів, передбачених КК, має умовно «негативний відтінок», який, імовірно, і орієнтує на його вузьке розуміння - на позначення виключно незаконної дії. Однак, більшою мірою це стосується самого терміну, який доцільно або замінити на більш вдалий, або забезпечити 
йому законодавче визначення поняття в примітці до однієї зі статей Особливої частини КК;

3) термінологічний та понятійний апарати КК України повинні бути однозначними у своєму змісті для забезпечення зрозумілості змісту закону про кримінальну відповідальність, тому пропонований нами підхід дозволить криміналізувати діяння з урахуванням місця його вчинення, а не лише місця та способу потрапляння до цього місця, які викликали неоднакові підходи судового правозастосування;

4) згідно з п.22 ч.1 ст.92 Конституції України виключно законом мають визначатися діяння, які є злочинами та відповідальність за них. Виходячи з цього конституційного припису, а також враховуючи те, що ознака «проникнення» зазнавала кілька протилежних правозастосовних тлумачень з боку касаційної інстанції України, цілком очевидно, що відповідний нормативний припис КК України потребує змін.

Описані пропоновані нами зміни змісту кваліфікованих складів злочинів, де використана формула «діяння (крадіжка тощо) поєднана 3 проникненням», доцільно замінити на формулу «діяння (крадіжка тощо) вчинена щодо майна, яке знаходиться в житлі чи іншому володінні особи», яка не зв'язана у своєму змісту жодним чином 3 конкретним способом потрапляння винної особи до приміщення, в тому числі, в частині законності або незаконності входу i перебування в ньому. При цьому, відповідні положення статей Особливої частини КК України доцільно викласти таким чином:

- ч.3 ст.185: «3. Крадіжка, вчинена щодо майна, яке знаходилось в житлі, приміщенні, сховищі чи іншому володінні особи...»,

- ч.3 ст.186: «3. Грабіж, вчинений щодо майна, яке знаходилось в житлі, приміщенні, сховищі чи іншому володінні особи...»,

- ч.3 ст.187: «Розбій, спрямований на заволодіння майном, яке знаходилось в житлі, приміщенні, сховищі чи іншому володінні особи»,

- ч.2 ст.289: «2. Ті самі дії, ...вчинені в приміщенні, сховищі...». 


\section{2 Кримінальні покарання та заохочення як парні правові категорії: гносеологічний аспект}

Права і свободи людини та їх гарантії, - наголошується у ст. 3 Конституції України, - визначають зміст і спрямованість діяльності держави. Держава відповідає перед людиною за свою діяльність. Утвердження і забезпечення прав i свобод людини $є$ головним обов'язком держави [85]. Юридична відповідальність відіграє значну роль серед правових заходів, безпосередньо покликаних сприяти реалізації конституційного обов'язку держави. Суспільна цінність відповідальності обумовлюється ії̈ подвійною правовою природою: 3 одного боку, це основний захід державного впливу, що забезпечує реалізацію законодавства, з іншого, - гарантує всім суб'єктам права безумовну реалізацію ïx законних прав i свобод, поновлює їх у разі порушення. Кримінальна відповідальності безпосередньо пов'язана 3 таким функціями держави як створення і підтримання правопорядку, всебічна реалізація прав і свобод особи, стимулювання правомірної поведінки громадян. Правомірна поведінка $\epsilon$ головною метою у кримінально-правовому регулюванні, де на першому місці знаходиться кримінально-правова норма, що містить правову вимогу (заборону чи дозвіл) та суб'єкт кримінально-правового відношення, - iї адресат людина, спроможна усвідомити вимогу закону та співвіднести із нею свою поведінку. Кримінально-правова норма зумовлює необхідність відповідної реакції держави на вчинення як протиправної, так і правомірної поведінки, по-перше, тому, що так зобов'язує суспільна необхідність та, по-друге, тому, що цього потребує й природа позитивного права.

Кримінальна відповідальність є важливим засобом регулювання (охорони) суспільних відносин, сутність якого полягає у цілеспрямованому впливі на поведінку особи за допомогою правових засобів, 3 метою упорядкування суспільних відносин, надання їм системності й стабільності, уникнення соціальних конфліктів, втілення соціальної справедливості, цивілізованості та високої правової культури суспільства. В сучасних умовах реалізація принципу невідворотності кримінальної відповідальності й покарання зазнає раціональної 
модифікації. До механізму кримінально-правового регулювання залучаються засоби, засновані на стимулюванні правомірної, суспільно-корисної поведінки. Слід прогнозувати, що сфера їх застосування буде розширюватися, що $\epsilon$ природнім об'єктивним процесом, зумовленим не тільки неоднорідністю та складністю правового регулювання, але й гуманізацією всіх сторін суспільного життя [86, с. 363-364]. Так, тенденцією останніх років є значна кількість осіб, які здебільшого вперше вчинили злочини невеликої та середньої тяжкості, та до яких біло застосовано заохочення у вигляді звільнені від кримінальної відповідальності у разі здійснення ними відповідного комплексу правомірної суспільно-корисної поведінки. За останні п’ять років кількість звільнених від кримінальної відповідальності відповідно складала: у зв’язку з дійовим каяттям (ст. 45 КК) в 2015 р. - 1263, 2016 р. - 1072, 2017 p. - 1420, 2018 p. - 1811, 2019 p. - 1914 осіб; у зв’язку з примиренням винного з потерпілим (ст. 46 КК) в 2015 р. -3143, 2016 р. - 2902, 2017 р. - 3010, 2018 р. - 2980, 2019 р. - 3347 осіб; у зв’язку 3 передачею особи на поруки (ст. 47 КК) в 2015 р. - 630, 2016 р. - 457, 2017 p. 428, 2018 р. - 367, 2019 р. - 375 осіб; у зв’язку із зміною обстановки (ст. 48 КК) в 2015 p. $-865,2016$ p. - 601, 2017 p. - 422, 2018 p. - 471, 2019 p. - 466 осіб [87, c. 50-52].

Реалізація принципів гуманізму, економії кримінальних засобів примусу об’єктивно зумовлює появу норм, які заохочують, стимулюють осіб, що потрапили у сферу кримінально-правового регулювання, вчиняти правомірні, соціально-корисні діяння, загалом поводитися як законослухняні громадяни. Закон повинен гарантувати громадянам суб'єктивне право самостійно протидіяти суспільно-небезпечним та злочинним нападам, а у випадку вчинення особою злочину, - покаятися, спокутувати свою провину перед потерпілим, суспільством і державою позитивної поведінкою у виді добровільного повідомлення про вчинене, дійового каяття, примирення 3 потерпілим, здачі суспільно-небезпечних предметів та засобів, сприяння розкриттю вчиненого злочину та інше. Кримінально-правове забезпечення цього суб'єктивного права є важливою правовою гарантією дотримання прав і свобод людини в сучасному 
українському суспільстві. Заохочення, як різновид кримінально-правових заходів, визнаний більшістю вченими-правниками знайшов реалізацію саме в кримінальному праві у вигляді заохочувальних норм [88, с. 162-163].

Віддзеркалення складної взаємодії негативного та позитивного аспектів кримінальної відповідальності окреслюється не тільки виключно проблемним характером, а й має інноваційне значення для сучасної юридичної науки й для теорії кримінального права, зокрема. «Наукові юридичні поняття і категорії, вказує В.М. Селіванов, - як форми відображення, опосередкування у певних юридичних знаннях правової й державної дійсності, формуються на основі повторюваності соціальних, зокрема юридичних, явищ i процесів, що потребують свого впорядкування, урегульованості, задля блага цілого, зокрема державно впорядкованого суспільства. Вони є певним підсумком пізнання реальної державно-юридичної дійсності і становлять певний результат конкретного теоретичного синтезу вже напрацьованих юридичною наукою i використовуваних нею для пізнання зазначеної дійсності понять і категорій» [89, с. 13]. Дослідження кримінальної відповідальності з використанням парності юридичних категорій розкриває нові можливості впливу на суспільні відносини, що $\epsilon$ предметом кримінально-правової охорони (регулювання). Проблема парності покарання і заохочення при реалізації кримінальної відповідальності $є$ маловивченою [90, с. 3; 91, с. 194]. Натомість, дослідження кримінальноправової матерії з цих позицій значно розширюють пізнавальні можливості, розглядають зазначені правові явища у взаємозв'язку i взаємозалежності, повніше фіксують їх внутрішні зв’язки, чіткіше встановлюють як елементи єдності, так і протилежності. О.М. Васильєв зазначає, що «для віднесення юридичних категорій до кола парних категорій необхідно визначити специфічну єдність протилежностей і розкрити їі через відмінність, тотожність, переходи відносно до суттєвого першого, другого i т.д. порядку, що проявляється у роздвоєнні протилежних моментів і сторін» [92, с. 18].

Кримінальні покарання i заохочення $є$ протилежними варіантами реагування держави на правову поведінку. Так, реалізація негативного аспекту 
відповідальності передбачає осуд особи з боку держави та реальні обмеження особистого чи майнового характеру. Покарання, як правило, проявляється у реальному обмеженні прав i свобод засудженого. «Сутністю кримінальної відповідальності як категорії публічного права, - слушно вказує Ю.В. Баулін, - $є$ обмеження прав і свобод злочинця. Така відповідальність існує в трьох аспектах: законодавчому, судовому та виконавчому. Зміст кримінальної відповідальності становить взаємодія трьох її складових елементів - суб’єктів, об’єктів та діяння. Правовою формою законодавчо визначеної кримінальної відповідальності $\epsilon$ санкція кримінально-правової норми, передбаченої КК; індивідуально визначеної судом - обвинувальний вирок суду і реально здійснюваної діяльність органів виконавчої влади, спеціально уповноважених на виконання обвинувального вироку суду» [93, с. 334]. Заохочення ж, навпаки, полягає у різний спосіб мінімізації, передбачених кримінальним законом, обмежень прав i свобод особи. Суспільно-корисна поведінка особи у більшості випадків задовольняє матеріальні і моральні вимоги потерпілого від злочину, прискорює розкриття, посилює ефективність розслідування злочинів та формує притилежну альтернативу традиційним засобам правого впливу у вигляді кримінального покарання.

У загальнотеоретичних дослідженнях немає єдності щодо ознак парності правових категорій. Так, О.В. Малько визначає, що парні юридичні категорії: 1) виражають дуалістичність юридичної інформації; 2) внутрішньо діалектично пов'язані; 3) взаєморегулюють одна одну; 4) визначають у своїй сукупності специфічний баланс мотиваційних правових засобів; 5) є двома узагальнюючими категоріями, що включають основні юридичні засоби у сфері інформаційнопсихологічної дії права [94, с. 110]. Іншої думки з цього питання дотримується В.В. Нирков, що вказує п’ять головних і взаємозалежних ознак цієї взаємодії: 1) єдність протилежностей; 2) їх взаємовиключення та взаємозаперечення; 3) їх співставлення та взаємопроникнення; 4) взаємоперетворення, взаємоперехід протилежностей; 5) нерівноцінність протилежностей у ході взаємодії [95, с. 46]. Не вдаючись до детального аналізу зазначених точок зору, - бо це складна 
філософська проблема, що заслуговує окремого дослідження, зазначимо, що відправною позицією у визначені ознак парних правових категорій $\epsilon$ матеріалістична діалектика та пї «ядро - закон єдності та боротьби протилежностей». Ще один із засновників грецької античної філософії, Геракліт помітив, що все в світі складається $з$ протилежностей Сутність єдності та боротьби протилежностей визначає сенс будь-якої речі, процесу, явища, в тому числі й соціального. Діючи одночасно, ці протилежності утворюють напружений стан, котрим i визначається внутрішня гармонія речі. Геракліт пояснює цю тезу відомим прикладом стрілецького луку: обидва дугоподібних кінці луку намагаються розігнутися, але тятива стягує їх, і ця їхня взаємна напруженість утворює вищу єдність. Боротьба протилежностей є загальною, вона становить справжню справедливість і $є$ умовою існування будь-якої упорядкованої системи. Закон єдності та боротьби протилежностей відображає фундаментальну особливість об’ єктивної дійсності, котра полягає в тому, що всі iї предмети, явища і процеси мають суперечливі моменти тенденції, сторони, що борються і взаємодіють між собою [96]. «Істина протилежностей, - підкреслював Г.В.Ф. Гегель, - полягає лише у їх відношенні одне до одного, тобто, у тому, що кожне з них у самій своїй суті передбачає протилежне» [97, с. 63]. Зміст цього закону влучно окреслив один з фундаторів матеріалістичного вчення Фрідріх Енгельс, який писав, що одна сторона протиріччя так само немислима без іншої, як неможливо мати у руці ціле яблуко після того, як з'їдена його половина [98, с. 70]. Покарання і заохочення як протилежні сторони реалізації кримінальної відповідальності характеризуються, на наш погляд, взаємозв’язком та взаємозалежністю, які проявляються безпосередньо у їх: а) взаємній єдності; б) взаємовиключенні; в) взаємопроникненні; г) взаємопереході у інші порядки правових категорій. Розглядаючи в цьому дослідженні парність кримінальних покарання і заохочення ми будемо виходити саме із вищевказаної послідовності їх взаємозв’язків та взаємозалежностей.

Взаємна єдність покарання і заохочення полягає у тому, що, по-перше, вони існують у рамках кримінального законодавства як єдиної, публічної, 
охоронної галузі законодавства України; по-друге, покликані забезпечувати єдине для обох завдання правового забезпечення охорони прав і свобод людини i громадянина, власності, громадського порядку та громадської безпеки, довкілля, конституційного устрою України від злочинних посягань, а також запобігання злочинам; по-третє, пронизані єдиними галузевими принципами законності, справедливості, гуманізму, особистої, винної відповідальності, індивідуалізації відповідальності та покарання тощо; вчетверте, виступають у якості регуляторів єдиної системи суспільних відносин, що виникають у зв'язку iз вчиненням злочинів та суспільно-небезпечних посягань. Природно, що пріоритет у справі охорони суспільних відносин кримінально-правовими засобами віддається переважно формі реалізації негативної кримінальної відповідальності у вигляді покарання. Має рацію В.Я. Тацій, коли зазначає, що предметом кримінально-правового регулювання виступають насамперед ті суспільні відносини, які виникають у зв'язку з вчиненням злочину [99, с. 108]. Проте, на нашу думку, зводити об'єкт регулювання кримінального права тільки до суспільних відносин, що виникають 3 зв'язку із вчиненням злочинів $\epsilon$ односторонньою i неповною позицією. Законодавець має точно і повно визначити межі правомірного та неправомірного, тим самим створити умови для правильного застосування кримінального закону.

I.Е. Звечаровський заперечує парність покарання і заохочення виходячи 3 того, що заохочення протистоїть відповідальності та визнає їх однопорядковими структурними елементами стимулювання. «Заохочення, - наголошує цей дослідник, - $\epsilon$ закономірним наслідком юридичної оцінки позитивновідповідальної правової поведінки. На рівні держави, як суб'єкта відношення відповідальної залежності, заохочення - це і $є$ позитивна відповідальність (відповідь), так само як покарання - одна 3 форм прояву негативної відповідальності» [100, с. 112]. Близьку думку висловлює й В.М. Баранов, котрий вважає, що стимулювання є одним із тих діалектичних понять, яке виражає тотожність, охоплює єдність двох відносних протилежностей - заохочення $\mathrm{i}$ відповідальності. Якщо відповідальність $є$ негативною стороною методу 
стимулювання, то заохочення представляє його позитивну сторону [101, с. 6]. Зазначена точка зору здається занадто категоричною. Заохочення і покарання $\epsilon$ основними елементами правового впливу задля правомірної, суспільносхвальної поведінки, але для досягнення цієї мети використовують протилежні засоби правового впливу на свідомість i волю особи. Покарання на психологічному рівні діє як «певний бар’єр», правова заборона вчинення суспільно-небезпечних дій та має стримувати вплив негативних мотивівспонукань особи. Заохочення, навпаки, має збуджувати, активувати позитивні спонукання, які об’єктивуються у правомірних вчинках.

Взаємовиключення покарання i заохочення полягає, по-перше, у протилежних 3 боку суспільної цінності та оцінки фактичних та правових підставах їх застосування, по-друге, у неспівпадінні соціального та правового змісту їх сутності, по-трете, у різних правових підставах та наслідках застосування у кримінальному праві, вчетверте, у якості регуляторів протилежних систем виступають різні методи. Соціальна сутність покарання i заохочення $\epsilon$ протилежною. В.С. Трахтеров у якості обов'язкової ознаки кримінального покарання зазначав правову і моральну оцінку у вигляді осуду 3 боку держави [102, с. 3]. Реалізація негативного аспекту кримінальної відповідальності у будь-якій формі завжди пов’язана з негативною оцінкою вчиненого злочину з боку держави у вигляді осуду, що знаходить своє закріплення у обвинувальному вироку суду. Навіть найбільш поблажлива форма - «це обмеження особи, винної в учиненні злочину, у праві на «добре ім’я», тобто обмеження їі гідності» [93, с. 341]. У п. 1 постанови Пленуму ВСУ від 24 жовтня 2003 р. № 7 «Про практику призначення судами України кримінального покарання» зазначено, що призначаючи покарання, у кожному конкретному випадку суди зобов’ язані враховувати ступінь тяжкості вчиненого злочину, дані про особу винного та обставини справи, що пом'якшують чи обтяжують покарання. Особі, яка вчинила злочин, має бути призначене покарання, необхідне й достатнє для іï виправлення та попередження нових злочинів [103]. Навпаки, заохочення правомірної суспільно-корисної поведінки є державним 
схваленням. Заохочення передбачає як схвальну оцінку поведінки особи, так i зміну ставлення до особи з осуду на схвалення у разі вчинення нею правомірної поведінки. Так, скажімо схваленню підлягає поведінка, що не має і не може мати суспільно-небезпечного характеру та спрямована, як правило, на припинення суспільно-небезпечної (неправомірної) поведінки інших осіб (необхідна оборона, затримання злочинця, виконання спеціального завдання тощо). В преамбулі до постанови Пленуму ВСУ від 26 квітня 2002 р. № 1 «Про судову практику у справах про необхідну оборону» зазначається, що право кожного на необхідну оборону від суспільно-небезпечного посягання є важливою гарантією реалізації конституційних положень про непорушність прав і свобод людини i громадянина, про невід’ємне право кожної людини на життя, недоторканність іiі житла й майна, а також забезпечує умови для захисту суспільних інтересів та інтересів держави [104].

Своєрідне схвалення також передбачається у разі позитивної посткримінальної поведінки при закінченому злочині. Заохочення у цих випадках $\epsilon$ «актом прощення винної особи» в силу зникнення чи суттєвого Зниження суспільної небезпеки особи, яка його вчинила. В Загальній частині КК звільнення особи від кримінальної відповідальності має місце у зв’язку: 3 дійовим каяттям (ст. 45 КК); 3 примиренням винного 3 потерпілим (ст. 46 КК); 3 передачею особи на поруки (ст. 47 КК); із зміною обстановки (ст. 48 КК); із закінченням строків давності (ст. 49 КК); неповнолітнього із застосуванням примусових заходів виховного характеру (ч. 1 ст. 97 КК). Основна суспільна спрямованість полягає у психологічному впливі, спонуканні винних, у тому числі неповнолітніх осіб, які вперше вчинили злочини невеликої тяжкості або необережні злочини середньої тяжкості, крім корупційних злочинів, до щирого каяття, активного сприяння розкриттю злочину, повного відшкодування завданих ними збитків або усунення заподіяної шкоди, примирення із потерпілим, не ухилятися від заходів виховного характеру та не порушувати громадського порядку тощо. В Особливій частині кримінального права правомірна посткримінальна поведінка э підставою спеціального звільнення від 
кримінальної відповідальності у: ч. 2 ст. 111, ч. 2 ст. 114, ч. 3 ст. 175, ч. 4 ст. 212 , ч. 4 ст. $212-1$, ч. 2 ст. 255 , ч. 2 ст. $258-3$, ч. 4 ст. $258-5$, ч. 6 ст. 260 , ч. 3 ст. 263 , ч. 4 ст. 265 , ч. 4 ст. 289 , ч. 4 ст. 307 , ч. 4 ст. 309 , ч. 4 ст. 311 , ч. 5 ст. 321 , ч. 4 ст. 321 1, ч. 5 ст. 354, ч. 4 ст. 401 КК. 3 позицій запобігання злочинам заохочувальні норми поділяються на такі, що спрямовані: 1) на припинення злочину, самовикриття і викриття інших осіб винних у його вчиненні, активне сприяння розкриттю злочину (ч. 2 ст. 111, ч. 2 ст. 114, ч. 2 ст. 255, ч. 2 ст. 258-3, ч. 4 ст. 258-5, ч. 6 ст. 260 , ч. 4 ст. 289 , ч. 4 ст. 309 , ч. 5 ст. 321 , ч. 5 ст. 354 КК); 2) на виключення 3 обігу предметів, засобів, речовин, що становлять підвищену суспільну небезпеку (ч. 3 ст. 263 , ч. 4 ст. 307 , ч. 4 ст. 311 , ч. 5 ст. 321 , ч. 4 ст. 321 1 КК); 3) на повернення майна, здобутого злочинним шляхом, або на відшкодування завданих збитків (ч. 3 ст. 175, ч. 4 ст. 212, ч. 4 ст. 212-1, ч. 4 ст. 289 KК).

Зовнішній вплив на волю і свідомість суб'єктів кримінально-правових відносин носить різний характер, але в цілому зводиться до двох основних методів: імперативних приписів, реалізація котрих забезпечується застосуванням заходів примусу та диспозитивних норм, що спонукають до правомірної, суспільно-корисної поведінки. Метод заохочення суспільно-корисної поведінки виступає найпотужнішим стимулюючим фактором, що сильніше за інших, формує зацікавленість суб'єктів у позитивній поведінці, створюючи для неї режим найбільшого сприяння. Сутність правових стимулів та обмежень найбільш рельєфно відбивається у парності покарання і заохочення. Правові стимули розглядаються разом з правовими обмеженнями у зв'язку з тим, що вони виступають у якості парних юридичних категорій, які внутрішне діалектично пов'язані та взаємно обумовлюють одне одного в процесі правового регулювання. Основою методу заохочення $є$ добровільність невимушеність суспільно-корисної поведінки. Цей метод надає можливість вибору з декількох варіантів правомірного, бажаного варіанту поведінки та стимулює іiї шляхом виключення, звільнення або пом'якшення реального або потенційного кримінально-правового обтяження. Метод заохочення у кримінальному 
законодавстві окреслює такі моделі поведінки, що заслуговують позитивної суспільної оцінки. В цих моделях органічно поєднуються суспільні, державні і особисті потреби та інтереси, що приводить до взаємоприйнятного результату. Безумовно, суспільство зацікавлене у виконанні усіма громадянами кримінальноправових заборон, чим у значній мірі забезпечується правовий режим законності. Проте, якщо хтось вчинює злочин, держава встановлює заохочувальній припис, модель суспільно-корисної поведінки особи, що з власної волі не доводить злочин до кінця та супроводжує його звільненням особи від кримінальної відповідальності, якщо фактично вчинене діяння не містить складу іншого злочину (ст. 17 КК). Законодавець правовим заохоченням прагне забезпечити повне, всебічне поєднання суспільних і особистих інтересів у сфері кримінальноправового регулювання, яке б передусім, спрямовувалось на запобігання (попередження) злочинів.

Правові підстави та наслідки застосування покарання і заохочення $\epsilon$ взаємовиключними. Покарання породжує судимість як правовий наслідок. За авторським визначенням В.В. Голіни, судимість особи - це іiі правовий стан, створений реалізацією кримінальної відповідальності, що виникає внаслідок засудження іï обвинувальним вироком суду за вчинений нею злочин до будьякого покарання, який (стан) виступає підставою для державного осуду i застосування до особи передбачених законом протягом певного, установленого законом перебігу часу, обмежень та втрат і відіграє у системі кримінальноправових засобів роль сприяючого фактору досягнення і закріплення цілей покарання [105, с. 310]. Заохочення, навпаки, у формі, скажімо, звільнення від кримінальної відповідальності на підставах Загальної та Особливої частин КК передбачає одним 3 юридичних наслідків те, що факт вчинення злочину втрачає будь-яке кримінально-правове значення.

Взаємопроникнення покарання і заохочення діалектично неминуче. Про це свідчать елементи схвалення, що можуть існувати у покаранні та осуду у заохоченні. Так, у обвинувальному вироку суду, яким призначається покарання, за наявності обставин, що пом'якшують кримінальне покарання, суд повинен 
призначити покарання більш м'яке, ближче до нижньої межі або перейти до більш м'якого покарання, що не передбачене санкцією статті Особливої частини КК. Водночас, особа може зазнати осуду з боку держави у вигляді покарання, якщо у фактично вчиненому є ознаки іншого складу злочину при добровільній відмові (ч. 2 ст. 17 КК); при умисному заподіянні тому, хто посягає, тяжкої шкоди, яка явно не відповідає небезпечності посягання або обстановці захисту при необхідній обороні (ч. 3 ст. 36 КК); при умисному заподіянні особі, що вчинила злочин, тяжкої шкоди, яка явно не відповідає небезпечності посягання або обстановці затримання злочинця (ч. 2 ст. 38 КК) та ін. Взаємні переходи в інші порядки досліджуваних правових категорій спостерігається як у низхідному та і висхідному напрямках. Найбільш узагальнені соціальні категорії, що кореспондуються 3 заохоченням та покаранням, це методи соціального управління - переконання та примус. Переконання як метод соціального впливу на свідомість людей покликане без примусу схиляти до відповідної поведінки особу, що відповідає іï волевиявленню, розширяти свободу вибору варіантів поведінки. Воно знаходить свій прояв у вигляді психічного впливу, у процесі якого особа добровільно схиляється до громадської думки, свідомо привласнює цю думку як особисту цінність, із розумінням ставиться до неї, а також до такої поведінки, котра цій думці, відповідає. Примус - це метод, що передбачає примушення до відповідної поведінки засобами силового тиску, всупереч волевиявленню, звужуючи свободи вибору особи. Г.В.Ф. Гегель зазначав, що в людині можливо примусити чи підкорити тільки їі фізичну, зовнішню сторону, але воля людини, яка завжди вільна в собі й для себе не може зазнати примусу, хіба лише, якщо вона сама не відступить від фізичної, зовнішньої сторони, в якій iii тримають або уявляють, що тримають [106, с. 91]. Методи примусу i переконання є універсальними, такими що притаманні будь-якій регулятивній системі: звичаям, традиціям, моралі, у тому числі й праву. На побутовому рівні взаємопереходи заохочення та покарання спостерігається у впливі на поведінку людей таких найдавніших засобів як «батіг та пряник». Стародавній китайський філософ Конфуцій надавав велике значення політиці «батога й пряника» в 
управлінні державою. «Державний батіг - «лі», - вважав Конфуцій, - $є$ наріжним каменем соціальної організації суспільства, без «лі» не може бути порядку, а, отже, процвітання у державі: немає «лі» - немає різниці між государем i підданими, верхами і низами, старими і молодими. Лі встановлює порядок речей» [107]. Відтак, покарання і заохочення виступають парними правовими категоріями, що комбінуються як діалектичні єдності й протилежності, взаємозаперечують та взаємозумовлюють одне одного у реалізації кримінальної відповідальності. Засоби покарання і заохочення прямо передбачаються в кримінально-правових нормах як протилежні юридичні наслідки протиправної або правомірної поведінки. 


\section{SECTION 4. CRIMINOLOGY}

DOI 10.46299/ISG.2021.MONO.LEGAL.II-92-99

\section{1 Специфіка проведення товарознавчої екпертизи в Україні}

Реформування правової системи України в частині процесуального законодавства, системи правоохоронних органів, судів тощо змінили підходи до використання спеціальних знань як джерела доказу. При досудовому розслідуванні, судовому розгляді кримінальних, цивільних та господарських справ може виникати необхідність у призначенні товарознавчої експертизи та проведення пї експертами.

Специфіка товарознавчих досліджень постійно змінюється, оновлюється та вдосконалюється із розвитком ринкових відносин, що вимагає від експертівтоварознавців покращення якості роботи та підвищення професійної рівня та компетентності в даній галузі.

Правові основи організації і проведення судових експертиз в Україні визначені системою нормативних актів чинного законодавства, до яких, в першу чергу, належать: Кримінальний процесуальний кодекс України, Цивільний процесуальний кодекс України, Господарський процесуальний кодекс України, Цивільний кодекс України, Кримінальний кодекс України, Кодекс адміністративного судочинства України, Закон України «Про судову експертизу», Кодекс України про адміністративні правопорушення та інші відомчі нормативні акти, що стосуються діяльності науково-дослідних установ.

Стаття 1 Закону України «Про судову експертизу» від. 24.05.1994 дає таке поняття судової експертизи - це дослідження на основі спеціальних знань у галузі науки, техніки, мистецтва, ремесла тощо об’єктів, явищ і процесів з метою надання висновку з питань, що є або будуть предметом судового розгляду [108]. Тоді відповідно до статті 69 Кримінального процесуального кодексу України (далі - КПК) експертом у кримінальному провадженні $є$ особа, яка володіє науковими, технічними або іншими спеціальними знаннями, має право відповідно до Закону України «Про судову експертизу» на проведення 
експертизи і якій доручено провести дослідження об'єктів, явищ і процесів, що містять відомості про обставини вчинення кримінального правопорушення, та дати висновок з питань, які виникають під час кримінального правопорушення $\mathrm{i}$ стосуються сфери ії знань. Стаття 101 КПК висновок експерта - це докладний опис проведених експертом досліджень та зроблені за їх результатами висновки, обгрунтовані відповіді на запитання, поставлені особою, яка залучила експерта, або слідчим суддею чи судом, що доручив проведення експертизи [109]. Проведення судової експертизи передбачає наявність професійних вмінь та навичок у відповідній галузі, основу яких становить поєднання спеціальних знань і певний досвід їх застосування в різних ситуаціях. Професійні вміння проявляються у професійній компетентності судового експерта.

Сутність товарознавчої експертизи полягає в тому, що за допомогою спеціальних знань, якими володіє експерт-товарознавець, вивчити та дослідити споживчі властивості товарів, визначити фактичний стан виробів, їх якість та на основі цього обгрунтувати вартість цих об'єктів шляхом надання незалежних компетентних висновків. Отже, товарознавча експертиза - це дослідження властивостей товарів 3 метою визначення якості та відповідності існуючим стандартам.

Підставою призначення товарознавчої експертизи $\epsilon$ необхідність у спеціальних знаннях, тоді як підставою проведення - документ про призначення судової експертизи або експертного дослідження (постанова, ухвала, заява).

Основними завданнями при проведенні товарознавчої експертизи вважають [110]:

$\checkmark \quad$ визначення вартості товарної продукції;

$\checkmark$ визначення належності товарів до класифікаційних категорій, які прийняті у виробничо-торговельній сфері;

$\checkmark$ визначення характеристик об'єктів дослідження відповідно до вимог Українського класифікатора товарів зовнішньої економічної діяльності; визначення змін показників якості товарної продукції; 
$\checkmark$ установлення способу виробництва товарної продукції: промисловий чи саморобний, підприємства-виробника, країни-виробника;

$\checkmark$ визначення відповідності упакування і транспортування, умов і термінів зберігання товарної продукції до вимог чинних правил.

Подано орієнтовний перелік вирішуваних питань при проведенні товарознавчої експертизи [110]:

$\checkmark \quad$ Яка вартість об'єктів дослідження як на території України, так і за ії межами?

$\checkmark$ Яке найменування та призначення товарів?

$\checkmark$ Чи відповідають маркувальні дані дійсним товарним характеристикам товару?

$\checkmark$ Чи відповідає якість виробу вимогам стандартів, технічних умов, наданим зразкам за органолептичними показниками?

$\checkmark \quad$ Які дефекти має конкретний товар? Чи є ці дефекти істотними? Чи можлива реалізація (експлуатація) товару за наявності виявлених дефектів?

$\checkmark$ Які умови приймання, зберігання та відпуску товару?

$\checkmark$ Чи правильно виконані маркування та пакування товару? Чи відповідає маркування та пакування товару вимогам нормативно-технічної документації або зразкам?

$\checkmark$ Яким підприємством і коли виготовлено товар (за умови наявності маркувальної інформації або відповідних супровідних документів)?

$\checkmark$ Яким характеристикам відповідає товар згідно 3 Українським класифікатором товарів зовнішньоекономічної діяльності?

$\checkmark$ Який розмір матеріальної шкоди, заподіяної власнику майна внаслідок пошкодження цього майна (при пожежі, залитті тощо)?

$\checkmark \quad$ Яка ринкова вартість зерна (зернобобових культур) станом на дату укладення контракту (на поточну дату) з урахуванням його якісних показників?

При визначенні вартості об'єкта дослідження товарознавчої експертизи експерт має враховувати якісні показники (властивості) товару, його часовий фактор експлуатації та/або середньорічний норматив зносу. 
При оцінці об’єкта дослідження, який був у користуванні порівняно 3 іншими об'єктами оцінки подібного майна, що також були у користуванні (іншими словами - вживані товари) або з об'єктами оцінки подібного майна, що реалізуються на первинному ринку (іншими словами - нові товари) може вираховуватись знос. Зазвичай знос вираховується в двох випадках на товарний стан та наявність/відсутність комплектації.

Зносом (знеціненням) у Національному стандарті №1 «Загальні засади оцінки майна та майнових прав» від 10.09.2003 року № 1440 є втрата вартості майна порівняно з вартістю нового майна. Знос за його ознаками виникнення поділяють на фізичний, функціональний та економічний (зовнішній). Фізичний та функціональний знос може бути таким, що технічно усувається, i таким, що не усувається, або усунення його $є$ економічно недоцільним. Розглянемо детальніше кожен з видів зносу [111]:

Фізичний знос - знос, зумовлений частковою або повною втратою первісних технічних та технологічних якостей об'єкта оцінки. Даний вид зносу залежить від багатьох факторів: умов та режиму роботи; матеріалу виготовлення машин та обладнання; характеру змащення поверхонь, які труться; питомого зусилля та швидкості ковзання; стану навколишнього середовища (забрудненість, вологість тощо). Розрізняють два види фізичного зносу. До першого, відносять як такого, що виникає під впливом штучних та природних факторів. До другого - під впливом експлуатаційних факторів.

Функціональний знос - знос, зумовлений частковою або повною втратою первісних (споживчих) характеристик об'єкта оцінки. В основному зумовлений впливом науково-технічного прогресу. Іншими словами - це зміна властивостей виробів, що характеризується невідповідністю їх сучасному напрямку моди, стилю, технології тощо.

$\checkmark$ Економічний (зовнішній) знос - знос, зумовлений впливом соціально-економічних, екологічних та інших факторів на об’єкт оцінки.

Показники втрати якості виробів розраховуються двома способами - за один рік експлуатації та внаслідок зносу і наявності дефектів. 
Дефекти, що знижують споживчі властивості об'єктів товарознавчої експертизи, а також їх вартість, класифікуються за: місцем розташування, ступенем впливу на якість (малозначні, значні, припустимі, критичні, неприпустимі), причинами виникнення внаслідок різних негативних факторів, стадіями виникнення (сировинний, виробничий, невиробничий та експлуатаційний), можливостями усунення, умовами виявлення (явний та прихований).

Процес визначення вартості регулюється законом України «Про оцінку майна, майнових прав та професійну оціночну діяльність», Національним стандартом № 1 «Загальні засади оцінки майна та майнових прав» від 10.09.2003 року № 1440. Зазвичай передбачено визначення ринкової вартості об’єкта дослідження. Вартість визначається на минулий період (від декількох місяців до десятка років). До переліку об’єктів товарознавчої експертизи відносять визначення вартості споживчих товарів, машин, обладнання та сировини.

Відповідно до Національного стандарту № 1 «Загальні засади оцінки майна та майнових прав» від 10.09.2003 року № 1440 в товарознавчій експертизі визначають такі види вартості об'єкта дослідження, як [111]:

$\checkmark \quad$ Ринкова вартість - вартість за яку можливе відчуження об'єкта оцінки на ринку подібного майна на дату оцінки за угодою, укладеною між покупцем та продавцем, після проведення відповідного маркетингу за умови, що кожна із сторін діяла із знанням справи, розсудливо і без примусу.

$\checkmark$ Залишкова вартість заміщення (відтворення) - вартість заміщення (відтворення) об’єкта оцінки за вирахуванням усіх видів зносу (для нерухомого майна - з урахуванням ринкової вартості земельної ділянки при іiі існуючому використанні (прав, пов'язаних із земельною ділянкою).

Вартість заміщення - визначена на дату оцінки поточна вартість витрат на створення (придбання) нового об'єкта, подібного до об'єкта оцінки, який може бути йому рівноцінною заміною. 
$\checkmark \quad$ Вартість відтворення - визначена на дату оцінки поточна вартість витрат на створення (придбання) в сучасних умовах нового об'єкта, який $є$ ідентичним об'єкту оцінки.

$\checkmark \quad$ Вартість ліквідації - вартість, яку очікується отримати за об’єкт оцінки, що вичерпав корисність відповідно до своїх первісних функцій.

Розглянемо структуру побудови запитання в товарознавчій експертизі при визначенні вартості об’єкта дослідження. Отже, основними елементами повинні бути вказані: безпосередньо сам вид вартості; об'єкт дослідження із зазначенням повної назви відповідно до класифікації (торговельна марки, модель при наявності, основні параметри, що ідентифікують товар); дата оцінки та товарний стан об’єкта дослідження.

Також на експертизу може бути поставлене питання про вартість відсутнього товару (майна). У таких випадках у документі про призначення експертизи (залучення експерта) зазначається про відсутність об'єкта та вказуються матеріали справи, на підставі яких повинна проводитись експертиза (рахунки, товарно-транспортні накладні, описи в позовних заявах, протоколах допиту потерпілих тощо) [110].

При проведення судової товарознавчої експертизи експерт вивчає маркувальні позначення, які нанесено безпосередньо на виріб або містяться на заводському упакуванні, ярликах чи етикетках. Розглянемо детальніше написи (маркувальні позначення) на етикетках. Основна задача етикетки (бирки) - це надання точної, достовірної та зрозумілої інформації про виріб, текст якої повинен бути написаний державною мовою (написи чіткі, розбірливі, розміщені на видному місці та не повинні приховуватись іншою текстовою або графічною інформацією).

Нижче наведена обов'язкова інформація на етикетках (бирках, заводському упакуванні), яка необхідна експерту-товарознавцю при проведені товарознавчої експертизі: 
1) Офіційна назва об’єкта дослідження (назва встановлена нормативноправовим актом або національним стандартом), торговельна марка, модель, серія, товарна лінія тощо.

2) Інформація про фізичний стан: виріб концентрований, порошкоподібний, рідкий тощо (за необхідності).

3) Перелік та кількість інгредієнтів, склад, жирність, об’єм, маса, приналежність до статевовікової ознаки тощо.

4) Термін придатності (граничний термін / календарна дата) споживання, після закінчення якої виріб може вважатися небезпечним для здоров'я людини. Зазвичай вводяться терміни придатності з такими написами, як «Вжити до...», «Краще спожити до...», «Краще спожити до кінця...» тощо.

5) Країна походження та/або місце походження.

Якщо об’єкт дослідження відсутній, то експерти-товарознавці працюють із наданими документами. В яких обов'язково повинно бути відображено стан товару; різні процеси, які з ним відбуваються; здійснення товарних операцій (приймання, розбракування, розсортування, реалізація тощо) та має бути надано додаткову інформацію щодо товару. Перелік документів, що несуть додаткову інформацію при проведенні товарознавчої експертизи [112]:

$\checkmark$ документи, які містять інформацію щодо походження виробів (сертифікати, посвідчення якості, технічні паспорти, ярлики тощо);

$\checkmark$ товарно-супровідні документи, які характеризують якість товару та упаковки перед здачею його на склад готової продукції та відправкою покупцю (специфікації, рахунки-фактури, товарно-транспортні накладні, пакувальні аркуші тощо);

$\checkmark$ товарно-транспортні (відвантажувальні) документи, які містять інформацію щодо умов та строків транспортування (квитанція про приймання вантажу, залізнична накладна, комерційний акт і т. д);

приймальні документи, в яких зафіксовані характеристики якості товару при прийманні - дані про приймання та методи випробувань (акти розбракування, акти експертиз бюро технічних експертиз, акти лабораторних 
досліджень, дефектні відомості, журнали приймання та розбраковки товарів, акти уцінки та переоцінки, паспорти на товари тощо);

$\checkmark$ складські документи, які містять вимоги щодо умов зберігання товару, претензійні матеріали;

$\checkmark \quad$ процесуальні документи (протоколи огляду, довідки і т. д).

Аналізуючи специфіку проведення судової товарознавчої експертизи необхідно зазначити ступінь її складності та строки (термін) проведення.

Термін виконання судової експертизи встановлюється в межах: до 10 днів - щодо матеріалів, які належать до категорії простих досліджень; до 30 днів щодо матеріалів, які належать до категорії досліджень середньої складності; до 60 днів - щодо матеріалів, які належать до категорії складних досліджень; до 90 днів - щодо матеріалів, які належать до категорії досліджень особливої складності.

Аналізуючи вищезазначене, можна зробити висновок, що при проведені товарознавчої експертизи має значення наданий чи не наданий об'єкт дослідження, від того залежить, які методи буде використовувати експерт, чи показник втрати якості буде визначатись за один рік експлуатації або внаслідок зносу та наявності дефектів, а також від складності дослідження залежать і строки проведення судової товарознавчої експертизи. 


\section{2 Загальна характеристика організованих злочинних груп, що вчиняють контрабанду наркотичних засобів у сфері сучасних тенденцій наркобізнесу}

Постанова проблеми: Наркотизація населення набула масштабів, які загрожують здоров'ю нації, соціальній стабільності і безпеці держави. Вказана проблема в країні характеризується значним збільшенням розповсюдження наркотиків іноземного походження - героїну, кокаїну, амфетаміну та інших, які потрапляють контрабандним шляхом і вливаються в загальний наркобізнес [129, с. 1]. Вказаний процес здійснюється організованими злочинними групами та злочинними організаціями з метою отримання надприбутків i фактично став галуззю кримінального бізнесу.

Закон України «Про обіг в Україні наркотичних засобів, психотропних речовин, їх аналогів і прекурсорів» не визначає поняття наркобізнесу. Бізнес - це підприємницька діяльність, що дає прибуток. Наркобізнес - бізнес, що базується на незаконній торгівлі наркотиків. [131, с. 48].

Г.М. Бірюков, досліджуючи наркобізнес дійшов висновку, що він виступає у вигляді специфічного злочинного промислу, системи заборонених нормами національного i міжнародного права діянь: виробництво або закупівля наркотичних засобів, психотропних речовин та прекурсорів; доставка їх до місця реалізації; збут, продаж їх споживачам [116, с. 17]. На наше переконання контрабанда наркотичних засобів є складовим елементом у технологічному ланцюзі наркобізнесу, який практично пов’язаний з іншими злочинами у сфері незаконного обігу наркотичних засобів.

Е.В. Расюк виділяє наступні елементи наркобізнесу, що вчиняють організовані злочинні групи: великі просторові межі діяльності злочинних груп; застосування способів конспіративності наркодиллерів; значний рівень організації керівництва та ін. [130, с. 440].

I. Смірнова підкреслює, що наркобізнес - це організована складова незаконного обігу наркотичних засобів, психотропних речовин, їх аналогів i прекурсорів, життєзабезпечення якої підтримується завдяки проведенню 
систематичних незаконних операцій із вказаними речовинами організованими групами (злочинними організаціями), що утворює систему для отримання надприбутків та формує велику кількість активних особистостей. Наркобізнес залежно від його географії та ступеня активності характеризується різними видами. Дослідниця зазначає, що принципом поділу виступає у цьому разі територія - від поширення в межах одного або кількох регіонів окремо взятої конкретної країни до такого наркобізнесу, система якого поширюється на території 2-3 країн, а також наркобізнесу, системна злочинна діяльність якого охоплює цілі регіони, континенти. Видами наркобізнесу $\epsilon$ : внутрішньодержавний, який поділяється на локально-активний, регіональний та міжрегіональний; міжнародний, який поділяється на формально проміжноглобально активний та транскордонний транснаціональний [126, с. 480].

Наркобізнес - це нелегальний бізнес із наркотиками, здійснюваний організованою злочинністю. Це підтверджує дослідження В.Б. Івасенка, який вважає, що наркобізнес - незаконна діяльність, що вчиняються організованими злочинними групами 3 метою отримання високих прибутків в процесі вирощення, виготовлення, пересилання та розповсюдження наркотичних засобів, що в кінцевому результатів підриває економічні основи держави та наносить шкоду здоров’ю населеняю [121, с. 30].

За висновками українських експертів, обіг наркотичних засобів в Україні проводиться за допомогою злочинних груп з використанням міжрегіональних та закордонних зв’язків. Зазначені злочинні групи у своїй діяльності використовують недосконалість вітчизняного законодавства, бездіяльність правоохоронних органів та не перекриті кордони ближнього i дальнього зарубіжжя. У зв’язку з наданням Україні безвізового режиму, організовані злочинні групи легко інтегруються в міжнародну систему наркобізнесу. Для нашого i міжнародного суспільства необхідним $є$ створення спільної правоохоронної системи, яка би ефективно протистояла вітчизняним i міжнародним організованим формам злочинності, яка здійснює діяння пов’язанні з наркобізнесом [129, с. 1]. В результаті дослідження встановлено, що 
наркобізнес тісно пов'язаний з діяльністю великої кількості осіб (організованих груп), що передбачає активну діяльність 3 наркотичними засобами, яка здійснюються в процесі: вирощування (25\%); перероблення (28 \%); перевезення (контрабанда) (34 \%); реалізації споживачам (13\%). Зазначені особи об'єктивно змушені об'єднуватися в злочинні групи з метою досягнення матеріальної вигоди від злочинної діяльності та захисту від викриття.

B.I. Литвиненко дійшов висновку, що велику небезпеку для держави становить діяльність організованих злочинних груп, яка полягає не в кількості вчинених злочинів, а в об'єднанні злочинних груп у злочинні організації, котрі посягають на органи управління та влади, заражають їх корумпованістю, впливають на стан суспільства, їх зростаючі масштаби негативно позначаються на економічному процесі розвитку держави, демократизації і суспільного життя країни $[125$, с. 5$]$.

Форми організованої злочинної діяльності постійно розвиваються, змінюються іiі кількісні та якісні характеристики, і не лише під однобічним впливом змін соціального середовища, але й у взаємодії з ним. Діяльність організованих злочинних груп та злочинних організацій характеризує активне бажання залучати та змінювати загальнодержавні інститути у своїх цілях. У загальній структурі злочинності вона посідає центральне місце і $є$ «верхівкою злочинності». У злочинних групах їх лідери постійно підтримують відповідний мікроклімат із метою постійного вчинення ними конкретних злочинних діянь [123, c. 192].

О.М. Джужа, Я.Ю. Кондратьєв та інші вчені стверджують, що одним 3 актуальних завдань, що постає у теперішній час перед юридичною наукою, $є$ розроблення й здійснення ефективних заходів щодо посилення протидії організованим групам у сфері незаконного обігу наркотиків. В подальшому, відзначають дослідники, масштаби існуючої проблеми настільки зростуть, що зараз вони потребують постійного розроблення правового і методичного забезпечення з протидії наркобізнесу [123, с.30]. 
У світлі наведених вище теоретичних положень, організовану злочинну діяльність у сфері контрабанди наркотичних засобів можна визначити як системну сукупність дій підготовлюваних і вчинених спеціально створеними стійкими, законспірованими й захищеними від викриття злочинними групами, що займаються злочинною діяльністю на постійній основі з метою незаконного збагачення й одержання надприбутку.

Способи, якими найчастіше вчиняють протиправні діяння:

1. Вчинення контрабанди наркотичних засобів транснаціональними організованими злочинними групами. Визначити поняття групи як транснаціональної, що вчиняє контрабанду наркотичних засобів можливо за допомогою змісту статті 3 Конвенції ООН проти транснаціональної організованої злочинності 2000 року із Протоколами, де зазначено, що злочин, пов’язаний із такою діяльністю є тоді, коли даний злочин вчинений у двох i більше державах світу; вчинений в одній державі, але початок підготовки здійснювався в іншій; вчиняються на території держави групою, яка діє на території інших держав; злочин може бути вчинений в одній державі, а наслідки наступили в іншій [122, с. 554-606].

2. Вчинення контрабанди наркотичних засобів етнічними організованими злочинними групами. За даними правоохоронних органів України у 2015- 2020 pp. в Україні було виявлено 32 злочинних груп, які були сформовані на етнічній основі, чисельністю 1,1 тис. осіб, котрі були причетні до всіх видів протиправних діянь у сфері обігу наркотичних засобів. За зазначений період до кримінальної відповідальності було притягнуто 250 особи [120, с. 5].

Особливу небезпеку складають злочинні групи які формуються на релігійній основі (мусульманства). Такі групи мають міжнародні зв’язки i фінансують тероризм [117 с. 11].

3. Вчинення контрабанди наркотичних засобів організованими злочинними групами економічного спрямування. Вчинення контрабанди наркотичних засобів організованими злочинними групами економічного спрямування полягає у використанні злочинцями підприємств 
зовнішньоекономічної діяльності у сфері товарної торгівлі, фармацевтики, медицини, поставок для переробки наркотичної сировини, а також вирощування і переробки власної наркосировини 3 використанням іноземних додаткових компонентів та ін.

Організовані злочинні групи, що вчиняють контрабанду наркотиків, використовують створені приватні підприємства (у тому числі фіктивні) для легалізації доходів від індустрії наркобізнесу, яку варто розглядати як одну 3 ключових умов розширення незаконного обігу наркотичних засобів, а також інтенсивного поширення наркоманії з використання легальних і нелегальних бізнесових структур.

При цьому за оцінками фахівців правоохоронних органів, легалізовані кошти використовуються не тільки для продовження злочинної діяльності й гарантування іiі безпеки, але й вкладаються в найбільш перспективні види економічної діяльності.

Злочинні групи, що вчиняють контрабанду наркотичних засобів, 3 транснаціональними ознаками та етнічною спрямованістю, вирізняються високою згуртованістю, стійкістю, кримінальним досвідом і вмілою конспірацією впродовж тривалого часу. Такі групи вчиняють значну кількість контрабанди тяжких наркотичних засобів, більшість із яких залишається нерозслідуваною, а також, дестабілізуючи стан правопорядку, розширюють масштаби злочинних діянь. Вказані проблеми досконало досліджені професором Д. Никифорчуком [126, с. 680-682].

Аналізуючи практику, яка свідчить про те, що організована злочинність у сфері контрабанди наркотичних засобів виділилася в особливу самостійну форму. Основним причина полягає в тому, що організація злочинних груп як ефективно діючих кримінальних структур виявилася набагато більш вигідною, ніж індивідуальний, розрізнений і роз'єднаний злочинний промисел, пов'язаний 3 незаконними операціями з наркотиками.

Організовані форми злочинності $\epsilon$ складним явищем, своєрідним чинником політичної господарської проблеми в державі. Угрупування 
транснаціонального та етнічного спрямування постійно удосконалюють свою злочинну діяльність, завойовують території різних держав, створюють міжрегіональні та міжнародні наркокартелі. У сьогодні на території нашої країни діють організовані злочинні групи у сфері незаконного обігу наркотиків, які мають тісні зв'язки з окремими державними чиновниками та підприємцями i здійснюють суттєвий контроль над суб'єктами підприємницької діяльності [126, c. 539].

Злочинні групи транснаціонального, економічного i етнічного спрямування у діях яких містяться ознаки контрабанди наркотичних засобів, належать до безпосередніх об’єктів оперативно-слідчої діяльності правоохоронних органів України. Щодо таких груп, за наявності достовірної інформації, отриманої в установленому законом порядку, яка потребує перевірки оперативно-розшуковим шляхом, можуть бути заведені оперативно-розшукові справи, у межах яких здійснюються певні заходи ОРД, а також використовуються необхідні оперативні й оперативно-технічні засоби $[115$, с. 15 29].

3 метою ефективної протидії контрабанді наркотичних засобів вчиненої в складі групи, необхідно дослідити визначення та розмежування поняття «злочинна група», «організована група», «злочинне угрупування», «злочинне співтовариство» тощо.

Кримінологи досліджують причини і умови створення злочинних груп, розроблення заходів, спрямованих на їх припинення. Фахівців у сфері кримінального права цікавлять питання кримінальної відповідальності за злочини, які вчинила група з ознаками організованості. Практиків оперативнорозшукової діяльності інтересує тактика виявлення і документування злочинних дій, вчинених злочинними групами. У процесуалістів проблемою являється удосконалення тактики слідчих (розшукових) дій при розслідуванні групових злочинів.

У сучасній літературі вже висловлювалася думка про те, що суто кримінально-правовий або кримінологічний аналіз поняття, яке розглядається, 
звужує поняття таких груп. Розуміння такого поняття досягається комплексним дослідженням всіх юридичних наук і надає уявлення про всю сукупну єдність суттєвих ознак саме організованих злочинних груп, особистість їх учасників та їх організовану злочинну діяльність. Водночас, як зазначає Б.С. Воронцов, для визначення ознак злочинної групи необхідно використовувати і соціологічні науки, які дають поняття групового об'єднання [126, с. 53].

За теорією Б.І. Бараненка, системно-комплексний підхід дозволяє розглядати злочинні групи як: соціальні групи, тобто порівняно стійкі групи осіб, що об’єдналися на основі соціальних чи економічних інтересів і створені безпосередні зв'язки між їх членами (зрозуміло, в межах кримінального їх буття); соціально-психологічні утворення, тобто об'єднання людей, які характеризуються своєрідною протиправною поведінкою і діяльністю, а також особливою особистісною психологією, обумовленою фактом належності цих людей до вказаних соціальних груп; суб'єкти групової організованої злочинної діяльності, яка створює поєднання зусиль декількох осіб для успішної реалізації загальної злочинної мети, а також найбільш раціональні спільні дії (включаючи самі засоби, способи дій та їх результати) на основі визначених правил та процедур [115, с. 16].

Запропонований підхід призводить до об’єктивного розуміння організованих злочинних груп як суб'єктів групової організованої злочинної діяльності. Саме ці групи в сукупності зі злочинною діяльністю, яку вони здійснюють, визначають матеріальний зміст явища більш високого соціального рівня, тобто організованої злочинності, і одночасно виконують роль безпосередніх об'єктів оперативно-розшукового втручання у боротьбі з цією злочинністю. Науковці по різному характеризують поняття організованої злочинної групи:

- як об’єднання декількох осіб із антисуспільними поглядами для реалізації злочинних дій, які є кримінально карними; 
- як неформальне об’єднання осіб на основі вчинення суспільно небезпечних, протиправних діянь, які прагнуть до досягнення загальної мети, організовані певним чином і становлять один суб’єкт діяльності;

- як стійку групу, що складається 3 трьох і більш осіб, яка раніше організувалася для сумісного вчинення одного або декількох злочинів;

- як навмисно організоване злочинне утворення, що охоплює лідера (він же найчастіше являється організатором) і декількох спільників, які перебувають у попередньому зговорі і мають на меті отримання прибутку від злочинів різної;

- група характеризується заздалегідь спланованою і цілеспрямованою злочинною поведінкою й домовленістю про постійну злочинну діяльність;

- стале об’єднання трьох і більше осіб, які зорганізувалися для отримання матеріальної вигоди вчиненням одного або кількох злочинів;

- як стійку групу осіб, які заздалегідь об’єдналися для вчинення одного або кількох злочинів і мають у своєму складі організатора.

Водночас К.О. Чаплинський в процесі вивчення організованих форм злочинності визначив, що організована група складає початкову форму організації та є фундаментом всієї злочинності. Злочинці, які об’єднані в групу, мають високий ступінь криміногенності та психологічної згуртованості довкола лідера. Чим більше група вчиняє злочинів, тим більше збільшується термін їі дії. Розподілення ролей в групі здійснюється в залежності вміння членів виконувати окремі злочинні функції [132, с. 34].

B.I. Литвиненко, Г.М. Бірюков та I.В. Сервецький характеризують організовані форми злочинів як умисно зорганізоване злочинне утворення, що включає лідера (він же найчастіше організатор) і декількох спільників, що перебувають у попередній змові і мають на меті одержання доходів від вчинення злочинів різної чи однієї кримінальної спрямованості, здійснення яких вимагає організаційного й іншого підготовчого забезпечення: планування, технічної оснащеності, розподілу ролей, розробки способів запобігання відповідальності та ін. $[124$, c. 27$]$. 
В.М. Корнієнко і Б.В. Романюк за характером стійкості наводять ознаки видів організованих злочинних груп: до першої групи (проста) вони відносять об'єднання злочинців які вчиняють крадіжки, шахрайства, грабежі, їх чисельність нараховує 3-5 осіб; до другої групи науковці відносять осіб, чисельність яких становить від 5 до 10 членів (структурована) в якій виділяються ієрархічні ознаки. Така злочинна група вчиняє злочини постійно, як правило корисливонасильницькі злочини, між учасниками існує розприділення ролей та наявність головного лідера [126, с. 192-193].

Наступною рисою організованої злочинної групи являється ії стійкість. Група яка вчиняє контрабанду наркотичних засобів буде стійкою за умови якщо вона нараховує стабільну чисельність їі членів і мають єдині наміри щодо вчинення зазначених злочинів.

Така риса організованої злочинної групи як згуртованість визначається шляхом їх поєднання (спаяності) та одностайності у своїх намірах. Для таких ознак характерно віднести міжособистісні внутрішні взаємовідносини між членами групи, визначення загальних норм поведінки, підпорядкування одному лідерові, розприділення ролей в залежності кримінального досвіду, злочинна діяльність завчасно планується і направляється за узгодженням дій [126, с. 683].

Визначення ознаки стабільної організованої злочинної групи проводиться на основі встановлення ii постійної злочинної діяльності. Група являється стабільною, якщо вона вчасно поповнюється новими членами групи, які за об’єктивними чи суб' єктивними причинами вибули.

Так професор А.А. Музика до стійкої організованої злочинної групи відносить трьох і більше осіб, які об'єдналися за попередньою змовою для підготовки та вчинення кримінальних правопорушень. До обов'язкових ознак від відносить наявність домовленості про створення такого організованого об'єднання; наявність домовленості про вчинення злочинів; спільне планування протиправних діянь; визначення ролевих функцій для членів групи; доведення злочинних намірів до всіх учасників злочину [127, с. 94]. 
Б.І. Бараненко визначає організовані злочинні групи в залежності їx розвитку. Так, до першої групи відносить просте об'єднання в склад якого входить декілька членів, які вчиняють злочини за попередньою змовою. Такою групою керує організатор. До другого організованого об'єднання від відносить організоване угруповання, яке складається з об'єднаних двох і більше злочинних груп. Таке об'єднання з часом може перерости в злочинну організацію і мати чітку ієрархічну структуру 3 розподілом ролей та спеціальних ланок забезпечення [126, с. 17].

В окремих наукових дослідження визначається ще один вид організованих злочинних груп - організоване злочинне співтовариство (синдикат, мафія). Зазначене злочинне об'єднання має характерні ознаки, які визначаються великою територіальною діяльністю, наявністю правил прийняття в об'єднання нових членів, застосування засобів покарання для зрадників, встановлення обов'язкових (матеріальних) зобов'язань для постраждавши членів угрупування від правоохоронних органів тощо [126, с. 684].

Саме ці ознаки відносяться до механізму вчинення протиправних діянь, що в кримінальному законі визначаються обов'язкові ознаки організованих злочинних груп, які дають підстави для їх розподілу на види. У той же час на практиці визначення організованих злочинних груп на початковій стадії їх виявлення можливо тільки за допомогою додаткових ознак таких як: проведення злочинних сходок злочинних авторитетів, вчинення розборок між групами, факти викрадення людей, вимагання тощо.

Під час розслідування зазначених кримінальних проваджень виникають суттєві проблеми з визначення видів злочинних груп. У більшості випадків виявляються групи, які вчинили злочин за попередньою змовою (95 \%), дуже рідко без змови взагалі (5 \%). Для встановлення протиправного діяння вчиненого організованою групою в конкретному випадку необхідно зазначати, за якими ознаками злочинна група є організованою. При класифікації злочинних груп учені використовують і різні кваліфікуючі ознаки. Так, А.П. Герасименко, Ю.В. Дамов беруть за основу безпосередній характер діяльності учасників груп, 
характер суб’єктивного зв'язку між членами групи, роль кожного з учасників групи. По-перше, організованість включає структуру групи, форми, тактику діяльності, характер зв’язку між іiі членами тощо (об'єктивна ознака узагальнювальної властивості). По-друге, організована діяльність достатньо чітко оцінюється кримінально-правовими, соціальнопсихологічними, а також оперативно-розшуковими критеріями. Рівень формування злочинної групи визначає ступінь організації діяльності правоохоронних органів, зокрема оперативних підрозділів [127, с. 93].

Виявляючи організовані злочинні групи оперативно-розшуковим шляхом, необхідно зважати на дії їх членів, що мають охоплюватися нормою Кримінального кодексу України передбачених в ч. 3 статті 305 КК України.

У науці кримінального права дотепер існує точка зору, відповідно, зміст основних ознаки кримінального правопорушення, що вчинені групою тлумачиться винятково як співвиконавство.

Проте в деякій навчальній літературі з кримінального права України чітко зазначено, що ця змова може відбутися перед діянням, або на стадії замаху чи до нього [114, с. 203], в іншій - визнається можливість виникнення попередньої домовленості в процесі замаху [113, с. 191].

Досліджуючи правові норми Великобританії, встановлено, що основними джерелами визначення вказаної злочинної діяльності є статті кримінального права (парламентське законодавство) i судові прецеденти. Англійський кримінальний закон не передбачає поняття організованої злочинної групи, але використовує термін «змова». Пункт $2 \S 3$ Закону про кримінальне право передбачає, що особа, винна у змові з метою вчинення вбивства, карається довічним тюремним ув’язненням [ 118, с. 581].

Незважаючи на обов’язкові ознаки групи, зазначені у законі, існують інші, на які немає прямого посилання. Ці ознаки можна розглядати як додаткові. На основі вивчення кримінальних проваджень про злочинну діяльність організованих злочинних груп, які вчиняли контрабанду наркотиків, були виявлені такі додаткові ознаки: чітка ієрархія та наявність лідера; чіткий 
розподіл ролей і закріплення функцій у групі. В організованій групі ролі чітко розподіляються, одні члени беруть участь у підготовці протиправних діянь, інші - безпосередньо перетинають кордон 3 наркотиками, треті - забезпечують перевезення і збут наркотиків. Кожний знає свої обов'язки, тому група функціонує злагоджено й організовано; планований характер злочинної діяльності. Практично усі групи вчиняють контрабанду на основі заздалегідь розробленого плану. Тому тривалість функціонування таких груп неможлива без планування їх специфічної діяльності. 


\section{SECTION 5. PHILOSOPHY}

DOI 10.46299/ISG.2021.MONO.LEGAL.II-112-129

\subsection{Peculiarities of authentic translation of international regulatory legal acts in the aspect of difficulties of using terms}

Justification and relevance of the choice of research topic. The expansion of Ukraine's international relations is impossible without the conclusion of treaties, the adoption of norms and standards into the national system of legislation, which are determined by international instructions, resolutions, resolutions, etc.

The implementation of a certain legal act in the activities of public authorities, local governments, enterprises, institutions or organizations, regardless of ownership, is impossible without understanding the legal content of a document written in a foreign language. In this case, there is a need for professional translation by a specialist who has not only a deep knowledge of a foreign language, but also is guided by the law and legislation of certain states.

The problem of official translation is quite acute, which determined the relevance of this study from the smallest in the system of professional translation - a legal term and its role in modern terminology and the key difficulties in using terms when making authentic translations. In particular, it is worth noting the crucial importance of a competent approach to the translation of texts of multilateral international agreements. Inaccurate translation of these legal documents can lead to negative consequences in the form of non-fulfillment of obligations by the parties to the agreement at the international level or violation of the principle of conscientious fulfillment of obligations.

The problem of the quality of authentic translation of international regulations is in the focus of research of many both domestic and foreign scholars. The analysis of language features of professional translation was carried out by: V.V. Alimov, NV Artikutsa, D.H. Баранник, O.B. Borodin, MB Verbenets, IE Galishina, NK Garbovsky, A.L. Hydorus and so on. Research on the implementation of authentic 
translations from a legal standpoint were: Yu.A. Dorokhina, OO Drozd, S.O. Mosjondz, N.A. Orlovskaya and others.

Scientific works that have recently investigated this issue are OS Kolyusheva (English administrative and legal terminology in the administrative law of Ukraine, Kyiv, 2017) and Shevchenko TS (scientific supervisor Ph.D., associate professor Kononets YV) (Professional vocabulary of EU legal acts: semantic, functional-stylistic and translation aspects, Kyiv, 2019). Despite the coverage in these studies of the peculiarities and problems of translating authentic texts from English into Ukrainian, most issues of professional legal translation remain unresolved.

These circumstances together determine the relevance of this study, its scientific, theoretical and practical significance and led to the choice of topic.

Connection of work with scientific programs, plans, topics. The work was performed in accordance with the work plan of the scientific group of the Department of Ukrainian Studies and Foreign Languages for the 2020/2021 academic year of Dnipropetrovsk State University of Internal Affairs and corresponds to:

$\S 4.18$ of the Plan of research and development work of Dnipropetrovsk State University of Internal Affairs for 2021, approved by the Academic Council of this university from 26.11 .2020 protocol 3 and paragraph 6 of the list of general research topics of Dnipropetrovsk State University of Internal Affairs for 2020- 2021, approved by the Rector of the University on December 14, 2020.

The purpose and objectives of the study. The purpose of the research is to study the language of international regulations and the peculiarities of authentic translation from English into Ukrainian, as well as to find optimal ways to unify translations of English legal terminology.

To achieve this goal the following tasks are solved:

- to find out the place of a legal term in the system of modern terminology;

- to carry out genetic characteristics of Ukrainian and English legal terminology;

- to analyze the features of legal terminology in English;

- to consider the problems of translation of English-language international legal acts and the language of law in general; 
- to reveal the difficulties of using terms when translating international legal acts from English into Ukrainian.

The object of research is public relations, which arise in connection with the need for an authentic translation of the text of an international treaty or other legal act and the problems that may arise.

The subject of the research is the activity of a translator during the authentic translation of international legal acts.

Research methods. The methodological basis of the study combines general and special scientific concepts, theories and methods.

The following methods of cognition are used as a methodological basis of research: historical, empirical generalization, modeling and abstraction, dialectical, systemic, complex and others. Thus, for a general understanding of the term "term" and determining its place in the system of modern terminology, dialectical and empirical methods were used, which allows to generalize the basic features of the use of Ukrainian and English terms when translating authentic English texts.

The historical method was used during the analysis of the laws of formation and development of terminology of the Ukrainian and English languages. The systematic method was used in the analysis of the language of law and consideration of a set of problems that arise during the translation of authentic texts. Methods of modeling and abstraction were used in the process of forming applications to work on the information obtained as a result of the study. General epistemological methods of cognition are also widely used - induction, deduction, analysis and synthesis, which provided an opportunity for a complete and comprehensive study of the features of authentic translation of international regulations in terms of difficulties in the use of terms.

Scientific novelty of the obtained results. The result of this work were the following provisions:

for the first time:

- it is proposed to create a Unified and Unified Translation Service (in English), which will cover the peculiarities of the use of terms in English and Ukrainian and the 
use of single terms or idioms should be carried out in a unified and accessible form for all professionals;

improved:

- understanding the language of international regulations and its features;

received further development:

- solving certain difficulties in the use of terms during the authentic translation of the English legal text, which is covered in the main part of the work.

The practical significance of the obtained results is that the results obtained by the author can be used in: research activities - for scientific study of issues related to the official translation of international regulations;

law-making work - as a theoretical and methodological basis for the development of draft regulations or guidelines relating to a unified approach to the interpretation of legal terms in English;

law enforcement activities - to improve the forms, methods and means of activities of entities in the field of translation of international regulations; educational process during the training of translators or specialists in the field of international relations, international law; in practice - as an applied material in the implementation of official translations of English-language international regulations by public authorities, local governments, enterprises, institutions or organizations, regardless of ownership.

In modern jurisprudence, the means of speech are constantly updated and more and more new terms are formed, which is connected with the expansion of the spheres in which social legal relations arise, develop and terminate. The emergence of neoterms is due to the actualization of international relations and the growth of Ukraine as a state governed by the rule of law, which actively interacts with the world community in the legal field. Borrowing from English legal terminology is a significant proportion of terms adapted to national law, they are used in the settlement of relations in any sphere of society.

This study is based on the basics of English legal terminology and the study of Ukrainian terminology as a basis for adapting foreign terms and authentic translations 
of international law, which with the expansion of international relations have become an integral part of national law.

The terminology of jurisprudence is considered as a systematic set of terms that denote and explain legal reality. In legal terminology, the term is considered as a word, a linguistic unit that expresses a specific concept that belongs to the theory and practice of legal sciences, characterizes and identifies certain processes.

It is worth noting that legal terminology should be developed on the basis of the state national language, use its lexical resources, word-forming potential, but it is advisable to attract foreign borrowings. In our opinion, such borrowings are justified only when they are necessary and jurisprudence needs them for renewal and progress $[133,137]$.

The study of any phenomenon in linguistics or jurisprudence begins with the interpretation of its definition, the disclosure of philosophical, scientific and other aspects of knowledge. The study of the concepts of "term" and "legal terminology" is based on the interpretation of definitions and definition of the main features of the legal term and so on.

There is not a lot of ratification of the legal document, and in the introduction of the significance of the attributions and standards of the function of the state, the suspension of those enormous people. In Ukraine, the official authoritative translation of the most demanding is the legislative sphere, the spring, the procedure for the ratification of a specific international normative legal act and the implementation of the national legislation, the requirement for the ratification of the text of the treaty ...

At the Resolution of the Cabinet of Ministries of Ukraine dated 17 March 2006 to rock \# 353, I will call it "About the consolidated procedure of the official transfer of international treaties of Ukraine to the Ukrainian translation."

Ukrainian language text of the rich-sided international treaty

The translation of the glossary of terms "authentic translation" is given the beginning of the translation: "the translation of an official document, which has the same legal force with the original; According to international law, the text of the treaty 
can be adopted and accepted for one move, but the authenticity is established for two and more moves. " [134].

The Order stipulates that the official translation of various foreign treaties is to be authentic, the Ministry of Foreign Affairs of Ukraine [135].

T.V. Chernishenko at the prelude to legal inheritance of the unofficial translation of the legal text is completely out of the question, but the Ministry of Foreign Affairs of the Ministry of Justice of Unimportant on the price, respectfully, all the same will not forget about the uniformity of the implantation of legal terminology, but the changeover of international normative legal acts is not linked between itself by the same rules for the changeover of the term.

This is due to the fact that the Ministry of Foreign Affairs in the development of significant number of pardons, so that it is impossible to preserve the authenticity of the re-translation, may have the right to turn the text into additional support (editing). In is important to make stress on the word "has the right". Sometimes, from the thought that was given for the analysis of the previous, but the manifestation of the same pardon for the translated text of the agreement will destroy the authenticity, because it cannot be considered an official text.

For the current year, it is necessary to do respect for the quality of authentic transfers in Ukraine. This is due to the fact that the practice is not far away from the translation of international normative legal acts of Ukraine for existing legal documents.

So it is not for the decision of the inconsistency of the legal translation of documents at the instructions, or for the resolution of any resolutions passed by the sub-acts, to produce legally significant information to the point of creation. Danes have been directing on the visibility of problems in the sphere of the translation of authentic texts and of the respect for the establishment of a single standard for a competent translation of the law. As a matter of fact, English legal terminology, and there are few special features in the official texts, and the fact that there are such peculiarities in the life of terms, there may be options in the transition and the publication of single terms In such a rank, the end of a single service of an unified transfer (English language) is 
proclaimed, as if it were a significant drink in the middle of special events, as it would be engaged in a faculty transfer at the branch of law.

Before the most common difficulties in the development of terms, before the change of the legal act from the English language to the Ukrainian language, it is possible to introduce the manifestation in the English version of the design alternative to the Ukrainian term. For example, the word "right" in the English language can be displayed as a decal: "right" or "law". "Right" refers to the Ukrainian concept of subjective law, and "law" refers to the constructive law. At the same hour, the electronic vocabulary "Lingvo" proposes 16 versions of the translation of the word "law" into the Ukrainian language, and to direct a word of 100 words from the word [136, p. 268-269].

It's the very same thing to see the folding of the buildings for an hour to translate the texts of normative legal acts, which are called idioms. [136, p. 268-269].

When it comes to the obviousness of the singing difficulties at the crossroads of terms. From the same time, to the most common difficulties in the adaptation of terms, before the change of a legal act from the English language to Ukrainian, it is possible to introduce the manifestation in the English language of the decile alternative options for the Ukrainian term. 


\subsection{Existential-axiological dimension of decriminalization of consciousness and society}

In modern conditions, the question of determining the moral component of modern man in a rapidly changing world arises with new urgency. Today, when the world is facing impending globalization, the crisis of the European spirit, the destruction of values and theoretical ideas that seemed until recently strong and the only true, the question of the ontological foundations of human life is especially relevant philosophical research criminalization and decriminalization of consciousness and society.

The problem of criminalization and decriminalization of consciousness and society can not be considered in only one dimension, because these phenomena are closely related to both individual consciousness and the consciousness of a social unit. The latter is closely related to the phenomenon of identity, inherent in any human group. As L. Kolakovsky notes, the problem of collective identity is similar to the problem of personal identity [139, p.103].

That is why it is impossible to understand the essence of the first without analyzing the essence of the second, because certain aspects of personal identity have analogues in collective ways of life. Among such parties the author singles out: 1) substance or soul, or the intangible side of the personality; despite various discussions about the existence or non-existence of this phenomenon, which is not easy for empirical knowledge, in everyday experience every mentally healthy person uses the pronoun "I", with which he identifies his personality; without denying the duration of "I" there are serious problems with the phenomenon of personal responsibility and the very essence of public life; 2) memory is the next component of personal identity, because without the existence of the work of memory to talk about the continuity of "I" does not make sense; 3) focus on the future - is a kind of conscious project, which passes in the time coordinate system, and is existentially emotionally colored; 4) the body, which is an integral part of the identity of the human person, despite the fact that it itself is undergoing constant changes in the time continuum of existence; 5) a person's confidence that he has a beginning, which the latter can localize in time, despite the 
fact that purely physiologically can not remember its beginning in existence [139, p.105].

Now, considering all these characteristics, but in relation to collective identity, L. Kolakovsky reveals the structure and internal dynamic forces of collective identity. Thus, what is analogous to the metaphysical concept of substance in personal identity, in the collective dimension will be close to the concept of "national spirit", which is expressed in various forms of cultural life and collective action, and becomes especially pronounced in times of crisis. In fact, this spirit is a kind of basis for cultural phenomena, it is one that does not identify with them. It is also difficult to overestimate the place of historical for national identity. Such memory is often mixed with ideology, so it may not coincide with the historical chronology of events in its history. Nevertheless, for national identity, it is vital to realize that that the nation is a kind of continuation of what once existed in the past. The value of foresight, as well as for personal identity and national identity, is difficult to overestimate. Such foresight is closely related to the goal, which is often the main object of purposeful existence at both the individual and national-ethnic levels. The next aspect of collective identity, analogous to which is the body for personal identity, is territory. In the event that the people lost their territory, this role was often played by a common religion. An example of such a state is the history of the Jewish people. Finally, localization in time is almost always present in the cultural and ideological memory of the people, expressed in the forms of legends, songs, which refer to the act of foundation or the first ancestors that existed once in the past. The value of foresight, as well as for personal identity and national identity, is difficult to overestimate. Such foresight is closely related to the goal, which is often the main object of purposeful existence at both the individual and national-ethnic levels. The next aspect of collective identity, analogous to the body for personal identity, is territory. In the event that the people lost their territory, this role was often played by a common religion. An example of such a state is the history of the Jewish people. Finally, localization in time is almost always present in the cultural and ideological memory of the people, expressed in the forms of legends, songs, which refer to the act of foundation or the first ancestors that existed once in the past. The 
value of foresight, as well as for personal identity and national identity, is difficult to overestimate. Such foresight is closely related to the goal, which is often the main object of purposeful existence at both the individual and national-ethnic levels. The next aspect of collective identity, analogous to the body for personal identity, is territory. In the event that the people lost their territory, this role was often played by a common religion. An example of such a state is the history of the Jewish people. Finally, localization in time is almost always present in the cultural and ideological memory of the people, expressed in the forms of legends, songs, which refer to the act of foundation or the first ancestors both for personal identity and for national identity, it is difficult to overestimate. Such foresight is closely related to the goal, which is often the main object of purposeful existence at both the individual and national-ethnic levels. The next aspect of collective identity, analogous to the body for personal identity, is territory. In the event that the people lost their territory, this role was often played by a common religion. An example of such a state is the history of the Jewish people. Finally, localization in time is almost always present in the cultural and ideological memory of the people, expressed in the forms of legends, songs, which refer to the act of foundation or the first ancestors both for personal identity and for national identity, it is difficult to overestimate. Such foresight is closely related to the goal, which is often the main object of purposeful existence at both the individual and national-ethnic levels. The next aspect of collective identity, analogous to which is the body for personal identity, is territory. In the event that the people lost their territory, this role was often played by a common religion. An example of such a state is the history of the Jewish people. Finally, localization in time is almost always present in the cultural and ideological memory of the people, expressed in the forms of legends, songs, which refer to the act of foundation or the first ancestors which is often the main object of purposeful existence both at the individual level and at the nationalethnic level. The next aspect of collective identity, analogous to the body for personal identity, is territory. In the event that the people lost their territory, this role was often played by a common religion. An example of such a state is the history of the Jewish people. Finally, localization in time is almost always present in the cultural and 
ideological memory of the people, expressed in the forms of legends, songs, which refer to the act of foundation or the first ancestors which is often the main object of purposeful existence both at the individual level and at the national-ethnic level. The next aspect of collective identity, analogous to which is the body for personal identity, is territory. In the event that the people lost their territory, this role was often played by a common religion. An example of such a state is the history of the Jewish people. Finally, localization in time is almost always present in the cultural and ideological memory of the people, expressed in the forms of legends, songs, which refer to the act of foundation or the first ancestors then this role was often performed by a common religion. An example of such a state is the history of the Jewish people. Finally, localization in time is almost always present in the cultural and ideological memory of the people, expressed in the forms of legends, songs, which refer to the act of foundation or the first ancestors then this role was often performed by a common religion. An example of such a state is the history of the Jewish people. Finally, localization in time is almost always present in the cultural and ideological memory of the people, expressed in the forms of legends, songs, which refer to the act of foundation or the first ancestors [139, p. 101-105].

Human consciousness, connected with the public consciousness by numerous connections, will always be marked by a great social influence in the legal dimension. Such a close connection is based on the internal structure of the human personality, the social dimension of which was formed over many centuries of experience of coexistence in conditions of various kinds of hostility to the external environment. However, it should also be noted that this social dimension is not only the result of a long history of human evolution, but also an important manifestation of the transcendental-axiological dimension of the human personality, and to such an extent that in a state of social self-isolation all their consciousness, in this state a person often begins to lose the meaning of his life. As noted by EN Trubetskoy: "in selfish assertion, in separation from other people my life is meaningless and meaningless, because the objective good is in the union of all; ... The meaning of life is revealed in love and only 
in it; the path of selfishness is revealed as untruth in any careful and profound philosophical analysis, and the path of solidarity is revealed as truth "[142, p. 219].

Such a close connection of the individual with society is also found in the legal dimension. After all, the personal system of assessment of legal reality is largely a reflection of the general mentality of a particular ethnic group. At the same time, it should be noted: each individual perceives the attitudes of society not just mechanistically, but also through the personal-individual factor. Thus, in the legal dimension it is important not only one or another legal imperative that comes from society, but also the position of the individual himself: whether to perceive it and make it a valuable part of their own perception of reality, or, conversely, distance themselves from the latter by choosing a personal line behavior that pays little attention to the axiological meaning of the social and legal imperative. In this case, the individual will consider the criminal prohibition only on the grounds of preventing punitive sanctions, provided for violation of this prohibition. Of course, this approach is not entirely effective in reducing the criminalization of society. The most effective will be a genuine, deep perception of the requirements of society in the legal field and the integration of social and legal values into its own hierarchy of axiological dimension.

An important prerequisite for this is the moral and axiological healthy state of relations in society itself. Otherwise, the average individual, considering the behavioral and legal imperatives recorded in various official documents, propagated through various media, seeing that the latter are really just a means of control by one part of society to another, will not be able to accept these imperatives. If he sees in such imperatives a real benefit for the common good of all, he will be able, based on his own conviction, and not only on the fear of punitive sanctions, to accept these imperatives as if they were his own.

The legal dimension is deeply rooted in the structure of the human personality. And many illegal actions a morally healthy person will not perform not only out of fear of punishment, but also out of self-belief. At the same time, in the presence of injustice in the socio-legal dimension, a person cannot find that axiologically convincing support for certain prescriptions, and therefore in his mind considers himself free from 
prescriptions that in an unjust situation do not seem to be fulfilled. One example of this state of affairs is the situation that is often encountered in the functioning of totalitarian regimes.

The latter, grossly violating human rights, issue inhumane laws, which, due to their opposition to the natural rights of the human person, are effectively perceived by citizens of such regimes as illegitimate laws and as those whose implementation cannot be based on deep inner conviction. Thus, due to the gross violation of natural human rights and the existence of injustice in relation to the "state-man" in the minds of many ordinary citizens of the USSR was not considered theft of agricultural products for which they worked, where wages are unfairly underestimated by the employer. It has been repeatedly said that individuals who did so explained this behavior by saying that they "did not steal, but took their own." That is why "any criminal law decision of a criminalizing or decriminalizing nature must be made taking into account the predictability of its interaction with the system of individual rating scales ..., taking into account the possible attitude of the individual to criminal law. At the same time ... the development and assimilation of patterns of behavior depends not only on the type of social formation, but also on specific values and socio-psychological stereotypes that divide different social groups, as well as on individual characteristics "development and assimilation of patterns of behavior depend not only on the type of social formation, but also on specific values and socio-psychological stereotypes that divide different social groups, as well as on individual characteristics of the individual " development and assimilation of patterns of behavior depend not only on the type of social formation, but also on specific values and socio-psychological stereotypes that divide different social groups, as well as on individual characteristics of the individual "[138, p. 223].

Despite the not always successful implementation of law in the human dimension of existence, it should be noted: the absolute idea of law as such is part of the world ethical order, has an objective existence, and which does not depend on whether a person is aware of it or not. Just as objectively and independently of human consciousness, there are various laws of nature. At the same time, the natural law, 
which is self-evident for each person, is self-evident only in its general provisions: for each morally mature person the requirements of respect for other people's rights, observance of honesty in relations with people, etc. are clear. However, for the existence of human society in the historical-temporal continuum, it is extremely important to have more specific definitions of the action of natural law in certain cases of human existence. It is the positive right that is the essence, which performs this role of applying natural law to the real existential-temporal situation of human existence. As noted by IV Mikhailovsky, "positive law is the implementation of" natural law "in a particular social environment. This implementation is due to the data of place and time and therefore is nothing immutable; the conditions of one environment differ from the conditions of another, and therefore the law of one state may differ significantly from the law of another, the law of the state in one era may be opposite to the law of the same state in another ". the conditions of one environment differ from the conditions of another, and therefore the law of one state may differ significantly from the law of another, the law of the state in one era may be opposite to the law of the same state in another " the conditions of one environment differ from the conditions of another, and therefore the law of one state may differ significantly from the law of another, the law of the state in one era may be opposite to the law of the same state in another "[141, p. 307].

Of course, changes in positive law can vary considerably depending on the era, but it should be noted that these changes cannot be contrary to natural law. Otherwise, we can talk about a certain illegitimacy of the functioning of such a right, which would be contrary to the natural, because such a positive right would lose this metaphysicalaxiological basis, which makes it legitimate.

In fact, in this perspective, the importance of the "individual-state" relationship for understanding the causes and mechanisms of criminalization of individual and social consciousness becomes clear. The more unjust the policy of the state, the greater will be the distrust of the population in the legal dimension of its activities, and the greater will be the drift towards the criminalization of society and, consequently, public consciousness. The more a state violates the natural rights of the human person, the 
greater the danger of the prosperity of various criminal factors in the existence of such a state, which will result in the deterioration of the living conditions of the majority of the country's population. At the same time, it should also be noted that different forms of crime in socio-historical periods will also be different, and, accordingly, there will be other aspects of human existence that will deteriorate.

In this perspective, the data of an all-Russian survey conducted in 1999 by the Center for Social Forecasting are very valuable. The sample was based on the principle of cohort analysis, where the sample was built on the basis of five groups, divided by age, respectively: 18-25, 26-36, 37-47, 47-57, 57-67 years. It included 3,000 people, 600 in each group.

Residents of large metropolises, regional and district cities, as well as those who lived in working-class settlements and villages took part in the surveys. As for the socio-professional dimension of respondents, in this case, the respondents included representatives of almost all segments of the population, including workers and engineers of enterprises, mines and buildings, humanitarian and creative intelligentsia, workers in communications, transport and trade, entrepreneurs small and medium business, representatives of law enforcement agencies, villagers, retirees, as well as university students, students of vocational schools and 10-11 grades of secondary schools. Of particular interest was the survey on the characteristics of which characteristics are inherent in certain historical periods of Russia and the USSR. After all, we know from history: in the territory of present-day Russia for a long time there was a constant process of change of corporate power structures, which was often accompanied by the eradication of historical memory. Historical consciousness, on the one hand, is always based on a certain acceptability of traditions, as well as significantly influenced by ideological factors, and on the other - such consciousness is the result of a synthesis of personal social experience and a set of social norms that a particular individual perceived as a result of socialization. orientations. Due to the phenomenon of constant change in the historical memory of the people, caused by various ideological motives, several generations of Russians have had to rethink their views on the historical events in which they participated several times in their lives. 
which was often accompanied by the eradication of historical memory. Historical consciousness, on the one hand, is always based on a certain acceptability of traditions, as well as significantly influenced by ideological factors, and on the other - such consciousness is the result of a synthesis of personal social experience and a set of social norms that a particular individual perceived as a result of socialization. orientations. Due to the phenomenon of constant change in the historical memory of the people, caused by various ideological motives, several generations of Russians have had to rethink their views on the historical events in which they participated several times in their lives. which was often accompanied by the eradication of historical memory. Historical consciousness, on the one hand, is always based on a certain acceptability of traditions, as well as is significantly influenced by ideological factors, and on the other - such consciousness is the result of a synthesis of personal social experience and set of norms of society. orientations. Due to the phenomenon of constant change in the historical memory of the people, caused by various ideological motives, several generations of Russians have had to rethink their views on the historical events in which they participated several times in their lives. and on the other hand, such consciousness is the result of a synthesis of personal social experience and a set of norms of society, which a particular individual perceived as a result of the process of socialization into his system of value orientations. Due to the phenomenon of constant change in the historical memory of the people, caused by various ideological motives, several generations of Russians have had to rethink their views on the historical events in which they participated several times in their lives. and on the other hand, such consciousness is the result of a synthesis of personal social experience and a set of norms of society, which a particular individual perceived as a result of the process of socialization into his system of value orientations. Due to the phenomenon of constant change in the historical memory of the people, caused by various ideological motives, several generations of Russians have had to rethink their views on the historical events in which they participated several times in their lives.

During the survey, the entire study period was divided into five periods: Russia before 1917, the USSR during the reign of Stalin, the USSR under Khrushchev, the 
USSR under Brezhnev, and Russia under Yeltsin. It is necessary to realize that the survey data are only representatives of the historical consciousness of those people who participated in the survey. The latter, in turn, is significantly influenced by the ideological atmosphere in which the respondents were brought up and raised. That is why we must be aware that often their assessment of particularly distant pages of history does not always correspond to historical reality in the chronologically accurate sense of the word. After all, the very concept of history is quite ambiguous, as R. Kozelek notes, conveying the ideas of Hladenius that "there is a history of modernity that encompasses all living things; then - the future history, which is always waiting for us ahead and which we anticipate in our plans, hopes and fears, and finally the ancient history, which always begins with the death of the last eyewitness ... the buildup of ancient history occurs as generations disappear "[140, p. 317].

In the perspective of our study of the phenomenon of criminalization, it is interesting to pay attention to the following characteristics of each of the surveyed periods: corruption and bribery, social injustice, crime and banditry, bureaucracy, uncertainty about their future, difficult economic situation, discipline and order. Thus, the period that is the furthest from the present - Russia before 1917, is characterized, according to respondents, by the following phenomena: the level of corruption - 4\%, social injustice $-15.7 \%$, crime and banditry $-9.7 \%$ and low level of social protection - $6 \%$. The period of existence of the USSR under the leadership of J. Stalin was marked by a high level of fear in society $-68.7 \%$, which is the highest among all periods, the presence of ideals $-59.6 \%$ and the existence of discipline and order $-84.3 \%$, love for the Motherland $-71.8 \%$. This period is also characterized by low levels of corruption and bribery $-16.2 \%$, social justice $-12.6 \%$, civil and political freedoms $-2.9 \%$, bureaucracy $-5.9 \%$, crime and banditry $-10.3 \%$, social protection $-13.0 \%$. During the Khrushchev era, the USSR had the lowest rates of fear - 3.5\%, interethnic conflicts $5.6 \%$, crime and banditry $-4.8 \%$, uncertainty in the future $-2.8 \%$. For the USSR under L. Brezhnev, the lowest indicators of difficult economic situation were $-6.3 \%$, the highest indicators of social protection $-75.9 \%$, cheerfulness $-71.5 \%$, trust between people $-68.3 \%$, respect for the Orthodox Church $-70.7 \%$. Also in this period there was 
a low level of corruption and bribery $-15.4 \%$ and crime $-7.1 \%$. For the rule of Mikhail Gorbachev compared to the reign of Leonid Brezhnev were characterized by:

As for the existence of Russia under Boris Yeltsin, according to these polls, it has such indicators that are accompanied by a difficult economic situation - $89.3 \%$, fear - 50.6\%, ethnic conflicts - 84.8\%, crime and banditry - $95.6 \%$, bureaucracy $65.2 \%$, crisis - $92,7 \%$, uncertainty in their future $-93 \%$ social injustice $-92.4 \%$ and corruption and bribery $-81.8 \%$. In this critical state, discipline and order are only $2.0 \%$. Among the positive aspects of this period can be mentioned only the belief of a large part of the population that it is possible to become rich $-75.6 \%$ and increase respect for the Orthodox Church - 58.3\%.

Analyzing the statistics, we see a clear correlation between the existence of order, favorable economic situation, the existence of ideals in society, respect for natural human rights and, consequently, low levels of corruption, bribery, crime and banditry. According to F. Sherega, each of the studied periods corresponds to a certain model of law: for example, "for the stage before 1917 it is an authoritarian pseudolegal class of government; for the Stalinist period - corporate pseudo-legal dictatorship; for the Khrushchev period - the eclecticism of pseudo-legal and authoritarian rule; for the Brezhnev period - pseudo-legal bureaucratic management, which relies on the principality; for the Gorbachev period - bureaucratic arbitrariness, which uses anarchy and ignores the law; for the Yeltsin period - oligarchic lawlessness, which, however, proclaims the priority of the rule of law "[143, p. 21].

It is significant that each of the studied forms of government is presented as pseudo-legal, as it reflects the gap that stands between the real rule of law and the sad reality witnessed by the respondents.

Thus, the truth is the position that the existence of law and order and the economy as a sphere of material social relations is the foundation of all social life. They are in charge of all other spheres of human activity - politics, culture, morality, spiritual sphere. The level of social, spiritual, cultural state of society is determined in some way by the level of economic development and law and order. However, there is an active role of morality in social development, its reverse effect onconsciousness and society. 
DOI 10.46299/ISG.2021.MONO.LEGAL.II-130-142

\section{3 Колізії розвитку української ліберальної думки першої половини XIX століття}

Розглядаючи особливості зародження ліберальної доктрини в Україні існує думка про те, що у нас немає підстав шукати витоків українського лібералізму до початку XIX ст. Більшість дослідників погодиться з таким висновком тільки в тому випадку, коли йтиме мова про імперську суспільно-політичну думку, носієм якої зазвичай було російське дворянство. Стосовно ж витоків українського лібералізму, то ті ж самі дослідники намагаються показати його премодерний характер. Н. Гедікова, розглядаючи становлення ліберальної доктрини в Україні, стверджує, що «це тисячолітній процес, який з моменту свого зародження, становлення і розвитку, не дивлячись на всілякі історичні умови й багатогранну систему поглядів, завжди носив безперервний, поступальний і еволюційний характер. Кожен новий його етап - продовжує свою думку дослідниця - спирався на попередні досягнення конкретної епохи, збагачувався i доповнювався, як власними накопиченими традиціями, так i досягненнями світової ліберальної думки» [146, с. 83]. Н. Гедікова також зазначає, що як «самостійне науково-теоретичне вчення вона [ліберальна думка - уточ. автор] починає оформлюватися з середини XIX століття, набуваючи своєї істинної значимості на межі XIX-XX ст.» [146, с. 83].

Незважаючи на раціональність останнього зауваження Н. Гедікової, говорити про традицію ліберальної думки в Україні, що сягає тисячі років, наразі, немає жодних підстав. Українське суспільство розвивалося у контексті загальних тенденцій розвитку європейського соціуму, тому, до початку модерної епохи говорити про зародження ліберальної традиції немає сенсу. Якщо взяти до

уваги позицію Д. Чижевського щодо своєрідності української ментальності, невіддільною рисою якої $є$ «індивідуалізм та стремління до «свободи» в різних розуміннях цього слова» [163], можна говорити про рецепції лібералізму як духовної настанови суспільства. Мислитель зосереджує свою увагу на тому, що «індивідуалізм може вести до самоізолювання, до конфлікту з усім та усіма, до 
розкладу усякої життьової форми; разом з тим індивідуалізм може вести й веде у деяких випадках до глибоко-позитивних форм творчості й активності. Поруч 3 цими двома рисами, стоїть третя - неспокій і рухливість, більш психічні, ніж зовнішні, неспокій і рухливість, що зв’язані із певним «артистизмом» натури, зі стремлінням до переходу в усе нові й нові форми, але разом 3 тим 3 індивідуалізмом, що не хоче мати ніяких сталих, міцних основ поза межами індивідуума, а не може відшукати їх в ньому самім; з цією рисою зв'язані і дуже позитивні риси характеру, як здібність до прийняття нового, тенденції до психічної еволюції, але і максимально негативні сторінки української історії «шатость», тенденція до взаємної боротьби, до руйнування власних і чужих життьових форм, усі жорстокі та криваві сторінки української історії» [163].

Попри визнання безсумнівного авторитету Д. Чижевського, його твердження $є$ не цілком правомірними. Зокрема, з огляду на високий рівень релігійності населення, що, як зауважував А. Антонович [144] та, особливо, I. Огієнко [157], проявлялася у вигляді двовір'я. Сумнівними є зауваження Д. Чижевського про те, що 3 українським індивідуалізмом була пов'язана здібність украӥнців до прийняття нового. Такий висновок $є$ доволі проблематичним, особливо у випадках, коли лібералізм розглядається не як політична доктрина, а як світоглядна настанова певної спільноти. Значна частина українського населення, яка ідентифікувала себе українцями, до початку ХХ ст. проживала у сільській місцевості, а відтак зберегла притаманний міфологічній свідомості біполярний світогляд.

Ця ситуація істотно нівелювалася на західноукраїнських землях завдяки тому, що освічене уніатське духовенство вело схожий до сільського простонароддя спосіб життя (подружнє життя, заняття землеробством). Це формувало відчуття нерозривної єдності між простим народом і духовенством. Неможливо оминути того факту, що це дало можливість останньому транслювати в це консервативне середовище нові світоглядні принципи та цінності, які були притаманні для цього періоду. В особливий спосіб ця тенденція проявилася у період після реформ Марії-Терези та Йосифа II, у 
кінцевому результаті яких уніатське духовенство зрівнялося із католицьким у правах та освіті [156, с. 414].

На території України, яка була підконтрольною Російській імперії ситуація істотно відрізнялася від тієї яка склалася на західноукраїнським землях, де у підсумку історико-культурного розвитку та політичної приналежності цінності та норми західноєвропейського світу хоча б частково транслювалися у середовище народних мас. Після приєднання Київського патріархату до Московської митрополії у 1685-1686 pp., завдяки європейській освіті вільнодумства усі елементи притаманного українському духовенству поступово придушувалися. Більше того, за словами Ю. Романенко та О. Донченко, східнохристиянська релігійна традиція характеризується виразним консерватизмом, який постав закономірним результатом пануючих тут архетипів вічного учня та вічного повернення [148]. У соціокультурному просторі ці архетипи проявлялися не тільки у глибокому консерватизмі, а й ворожості до усього нового, що й дало можливість С. Томашівському говорити про те, що вибір Володимира свого часу був трагічною помилкою, яка призвела до застою української культури та прирекла iї на безплідність та замкнутість [155, с. 7].

Експлікація І. Лисяка-Рудницьким поглядів С. Томашівського постає радше авторською інтерпретацією, ніж відтворенням світоглядних інтенцій творчості С. Томашівського, який вів мову передусім про необхідність подальшого розвою церковної унії в Україні, бо вона більше відповідає ментальності українського народу. Це чітко проявляється у ментальній інтенції українського індивідуалізму православного населення. На противагу уніатству, яке мало організаційний зв'язок із західноєвропейським світом, православне духовенство після інкорпорації Київського патріархату до складу Московської митрополії, втратило будь-яку можливість для вільнодумства. Це, у єдності притаманною сільському населенню біполярною міфологічною моделлю світу, робило українське простонароддя нечутливим до змін і нововведень. Як доводить Н. Кривда, саме дана обставина мала вагоме значення для збереження в децентралізованому вигляді самобутньої української культури [151], яка, 
зазвичай, була представлена властивим премодерній культурі колективним «Ми», що есплікувалося, як родина, як громада, як етнографічний регіон, однак завжди у протиставленні до «Вони». Власне саме у підсумку своєрідності українського двовір'я, який виявлявся у своєрідній обрядовій практиці, як стверджує Н. Кривда, сформувався етнографічний фундамент для формування колективного етнографічного «Ми», свідомість якого, як свідчить інтелектуальний дискурс кінця XVIII - початку XIX ст., утверджувалася під впливом антиукраїнської політики Російського уряду. Дивлячись, як традиційні життєві форми поступово зникають, етнічно свідомі представники козацької шляхти охоче збирали пам'ятки старовини - давні літописи, документи та архівні матеріали з метою зберегти на їх тлі минулу малоросійську велич [152, c.259].

Вплив біполярної міфологічної моделі світу, передусім, серед представників української шляхти особливо виразно проявився тоді, «коли російський уряд, починаючи з самої цариці Катерини II, докладав усіх зусиль для того аби не тільки назва, а і сама пам'ять про часи гетьманщини зникла, i щоб раз назавжди викорінився погляд, ніби українці - якийсь «окремий народ од москалів» [149]. Між тим, саме в цей час починають 3'являтися праці в яких обгрунтовувалася тяглість української політичної свідомості, що виразно проявилося у «Краткой летописи Малыя Россіи с 1506 по 1776 год» (В. Рубана), «Записках о Малороссіи» (Я. Марковича), «Історії Русів» (1829 р.) тощо. Як слушно наголошує О.Салтовський усі представники тогочасного інтелектуального дискурсу «стояли на позиціях консерватизму, тобто на позиціях визнання особливих цінностей традиційного ладу, традиційних форм життя, діяльності суспільства і держави. Консерватизм став їхньою ідеологічною платформою в боротьбі за збереження національних і станових привілеїв» [160].

Розвиток ліберальної думки в Україні сповільнювало й те, що становлення новітньої української еліти, що формувалася в університетах, відбувалося під ідейним впливом німецької філософії, а саме вченням Й.Шада. Він був незалежним дослідником філософії І. Канта і Й. Фіхте та виражав зацікавлення 
та повагу до свободи та гідності людини. Як зазначає М. Семчишин, вчений у цьому плані був співзвучний з традицією української інтелектуальної думки й, передусім, філософією Г. Сковороди. Й. Шад, на відміну від Г. Сковороди, у творчості якого ідея свободи не набула чітко раціоналізованої форми, був яскравим противником «всякого насильства над свободою» [161, с. 221].

Ідейна доктрина Й. Шада попри рецепції лібералізму у його філософії не одразу і не повною мірою визначила розвиток української соціогуманітарної думки. Це було зумовлено тим, що на початку XIX ст. українці були свідомі не тільки власної етнічної ідентичності, а й того, що залучення до передової європейської цивілізації вимагає культурної трансформації. «Поступово втягуючись у чужу їм цивілізацію... У своїх зусиллях утвердити себе як рівних на теренах не їхнього витвору цивілізації вони, мусили, так би мовити, вибудувати себе заново, створювати власні національні ідентичності. Нема сумніву в тому, - зауважує Дж. Пламенац, - що коли націоналізм вперше почав серед них вкорінюватися, то вони вже мали певне почуття ідентичності чи окремішності. Але було також усвідомлення того, що вміння, ідеї та звичаї, набуті від їхніх предків, $є$ неадекватними з огляду на необхідність піднятися до рівня більш передових народів, згідно зі стандартами цивілізації» $[158$, с. 488489].

Поширення соціальної теорії, й зокрема, теорії нації Й. Шада, а 3 ними запозиченої від німецьких романтиків цікавості до етнографії та фольклору, певним чином було зумовлене намаганнями віднайти спільні риси із передовими народами світу та звільнитися від російського панування i, особливо, винародовлення. Українська інтелігенція усвідомлювала те, що долучитися до цивілізації, яка є для них абсолютно чужою, можна тільки шляхом прийняття відповідної їм культури та мови, що обов'язково призведе, в кінцевому випадку, до знищення тих якостей та характеристик, які визначають їх власну народну культурну самобутність.

Вагоме значення, на думку I. Лисяка-Рудницького, для сприйняття національних ідей сформованих в межах німецької філософської думки й, 
передусім, творчості Й. Гедера, В. Гумбольдта та Й. Фіхте мало те, що стара «українська суто державницька національна свідомість ставала в умовах першої половини XIX ст. практично неплідною, ставила Україну перед примарою національної смерті. Висунення на перший план «мужицького» етнографізму замість панського політичного історизму, демократичного народництва замість аристократичного державництва під знаком «прав і привілеїв» було в той час єдиним порятунком для національної ідеї, єдиним можливим виходом 3 ідеологічно сліпого кута. Відкривало широкі шляхи для культурної творчості, шлях від вивчення життя мас до їх усвідомлення («просвітянство»), для всього того, що творило нові підстави майбутнього відродження державної ідеї» [154, с. 207]. Іншими словами, єдиним виходом для того аби зберегти українську ідентичність стало опертя політичних і культурних прагнень інтелігенції на народну масу. Звернення української інтелігенції до народу було закономірним ще й тому, що побудувати «нову Україну можна було лише на місці селянського народу, бо масові кадри інтелігенції можна було вербувати лише у верствах, наближених до селян: сільських священиків, дрібних землевласників, міщан, заможних селян козацького походження тощо» [147]. Натоміть українські землевласники, i, тим паче, підприємці, були великою мірою денаціоналізовані, а відтак їх цікавість Україною обмежувалася тільки економічною чи політичною сферами.

У суспільній свідомості українців, досить швидко поширилася думка про те, що для народу дуже важливим є відстоювати свою культурну ідентичність, «бути собі вірним», «наслідувати свій природний дух» і не дозволяти іноземним звичаям себе переваблювати [158, с. 490].

Розкриваючи історію ліберальної думки в Україні, Н. Гедікова звертає увагу на те, що в основу українського лібералізму «були покладені традиції, створені попереднім поколінням представників українського ліберального толку, зокрема ідеологами першої половини XIX століття (Т. Шевченком, М. Костомаровим, Г. Андрузьким, П. Кулішом та ін.), що явилися тією опозиційною силою, яка змогла протистояти режиму Миколи I (1822-1855)» [146, с. 84]. Подібні думки 
зустрічаються й у творах І. Лисяка-Рудницького, який в ідеології КирилоМефодіївського товариства бачить органічне поєднання трьох традицій: романтичного етнографізму й культурництва харків'ян; традиційного козацького державництва та модерних західноєвропейських ідей лібералізму та демократизму [154, с. 208]. Мислитель стверджує, що перша модерна українська політична програма взяла за основу ідею вільної української республіки.

Ïї грунтований аналіз дає можливість чітко визначити вплив західноєвропейського лібералізму на становлення української суспільнополітичної думки першої половини XIX ст. Аналізуючи колізії українського буття в історичній ретроспективі, М. Костомаров неодноразово звертається до необхідності максимально повної реалізації свободи. На користь висновку, щодо відсутності ліберальних тенденцій у творчості мислителя, слугує, як мінімум, запропонований ним аналіз змісту свободи в античній Греції. «Греки, - пише М. Костомаров, - не дізнались правдивої свободи, бо хоч одріклись царей земних, та не знали царя небесного і вимишляли собі богів; і так царей у їх не було, а боги були, тим вони вполовину стали такими, якими були б, коли б у них не було богів і знали б небесного бога. Бо хоч вони багато говорили про свободу, а свободні були не всі, а тільки одна частка народа, прочі ж були невольниками; і так, царів не було, а панство було: а то все рівно, якби у їх було багато царків» [162].

У запропонованому уривку, М. Костомаров визнає наявність свободи у давніх греків. Такий висновок, можна вважати цілком достовірним, тим паче, коли мова йде про свободу, як ключову цінність ліберальної доктрини. Немає жодних підстав виводити ії з античних часів, і тим паче говорити про наявність індивідуальної свободи у давніх греків. Схоже тлумачить М. Костомаров зміст свободи й тоді, коли говорить про українців. Так, наприклад, пропонуючи програму майбутньої слов'янської федерації, яка могла б цілком відповідати ліберальним принципам, М. Костомаров пише: «голос іiі [України - уточ. автор], голос, що звал всю Слов'янщину на свободу і братерство, розійшовся по світу 
слов'янському. I одізвався він, той голос України, в Польщі, коли 3 мая постановили поляки, щоб не було панів і всі були б рівні в Речі Посполитій; а того хотіла Україна за 120 літ до того» [162].

Розгляд свободи у єдності з рівністю, який пропонує М. Костомаров дає можливість стверджувати, що погляди мислителя мали республіканськодемократичне, а не ліберальне забарвлення. Дане зауваження цілком підтверджує специфіка тлумаченням мислителем проблеми рівності. В цьому контексті, особливу увагу привертає наступне твердження мислителя: «А сьому ще гірша неправда, бутсім установлено од бога, щоб одні пановали й багатились, а другі були у неволі й нищі, бо не було б сього, скоро б поприймали щире Євангеліє; пани повинні свободити своїх невольників і зробитись їм братами, а багаті повинні наділяти нищих, й нищі стали б также багаті; якби була на світі любов християнська в серцях, то так було б, бо хто любить к[о]го, той хоче, щоб тому було также хороше, як і йому» [162]. Наведене зауваження чітко демострує прихильність М. Костомарова до теорії соціальної рівності, в межах якої людина отримує громадські блага не стільки, скільки сама заробляє, а рівно стільки, скільки їх мають інші члени іiі групи. В межах такої концепції, розподіл соціальних благ набуває зрівняльного характеру, а значення людини в суспільстві визначається не у відповідності до її особистого трудового внеску, а відповідно до загального соціального статусу тієї соціальної групи, яку вона представляє.

Ліберали (А. Сміт, Б. Констанс, А. де Токвіль та ін.) розглядали рівність, крізь призму рівноправності, яка встановлюється за допомогою закону i спрямована гарантувати кожній людині індивідуальні права та свободи. Вони виступали за широкий розподіл праці, ринкову свободу і підприємницьку ініціативу, розуміючи найважливішу роль економіки в суспільному житті людей. Інакше кажучи, ліберали, розглядаючи проблему рівності, зосереджувалися не на рівності кінцевого результату, а на можливості ïi реалізації. Їх цікавило забезпечення цієї можливості для кожної людини отримувати відповідно до власних здібностей, а не результат. Такий підхід, без жодного сумніву, у 
реальному житті призводить до нерівності, яка стає закономірним результатом того, що люди нерівні у своїх трудових параметрах (фізична сила, розумові здібності, освіта, накопичення тощо).

Проблема рівноправності у творчості М. Костомарова мала непересічне значення, адже саме завдяки їй можна було побудувати справедливу слов'янську федерацію. У «Книзі буття українського народу» мислитель обгрунтовує християнський характер Слов’янщини, яка буде вибудована на основі любові до Ісуса Христа. Від самого початку утвердження християнства та розвитку перших християнських громад 3 притаманною їм рівністю, не було місця для індивідуальної свободи. Перші християнські громади формувалися керуючись словами Христа «Бо де двоє чи троє в Ім'я Моє зібрані, там Я серед них» (Від Матвія 18:20), зафіксованими у Свангеліє від Матвія і були єдино можливим способом долучитися до християнської істини, яка відкривалася людині у живій традиції співжиття у християнській громаді [150, с. 61]. Ситуація докорінно не змінилася і згодом, так як спільнота об'єднана навколо релігійного ядра, i, особливо, православ’я, не має простору індивідуальної свободи, оскільки в такій спільноті людина визначається крізь призму колективного «Ми». Саме такий підхід спостерігається у М. Костомарова, який веде мову не про звільнення від соціального поневолення кожної людини, скільки про деяке колективне «Ми» в даному конкретному випадку, 3 одного боку, слов'яни, тобто люди, що пов'язані своїм історичним походженням, а $з$ іншого - українці, чехи, поляки тощо, тобто ті, що мають власну етнічну ідентичність.

М. Костомаров, говорячи про «свободу та рівність», що сформувалися на тлі дотримання «закону божого», і проявлялися в тому, що українці, як ніхто в світі моляться богу, у «муж любив жону, а діти своїх родителей» [162] не брав до уваги архаїчний характер життя українського простонароддя $\mathrm{i}$, особливо, його двоєвірного характеру. Адже, первісна родова спільнота, формування «Ми», що представлені як domus, тобто сім’я, родина, передбачало виділення Космосу iз первинного Хаосу, тобто встановлення природного порядку, який би забезпечив безперервне життя родової спільноти. Кожна людина залежно від віку та статі, в 
межах такого Космосу, посідала своє власне місце і виконувала покладені на неї обов’язки. I те, і інше, було результатом встановленого «од віку» порядку, й не передбачало вільного вибору людини. Глибока взаємоповага в українській родині, на якій акцентували увагу багато українських мислителів, є результатом двоєвірного характеру життя українського простонароддя, яке намагалося утримати всесвітній порядок проявляючи зовнішньо соціальні функції.

Отже, наразі немає жодних підстав говорити про рецепції лібералізму у творчості М. Костомарова, який переймався свободою колективу, а не окремої особистості.

П. Куліш розглядає індивіда через його конотацію 3 історичною долею спільноти. Експлікація цієї ідеї здійснюється за допомогою вчення про «народний дух», який у творчій спадщині П. Куліша, тлумачиться як індивідуальний вияв, «трансцендентної субстанційної сили; він становить первень i сутність спільноти, праоснову народного буття i втілює себе символічно в предковічних цінностях народу, закодованих у його мові. Втрачаючи iị, народ губить ціннісні орієнтири, визначальний для себе модус світовідношення, а отже можливості «розвитку його моральних сил». Індивід, обезмовлюючись, позбавляє себе єдиного, даного Богом, способу залучення до духовно-культурних традицій народу і нікчемніє» [153].

Запропонована І. Лисим характеристика творчої спадщини П. Куліша не потребує жодних уточнень чи характеристик, адже в ній немає жодного натяку на ліберальні принципи. Проте, відкритим залишається питання щодо того, чому все таки провідні українські дослідники, в тому числі й Н. Гедікова, вбачають у поглядах згаданих дослідників рецепції лібералізму.

Відповідь на це питання отримуємо звернувшись до праць Ю. Габермаса, й, передусім, до здійсненого ним розрізнення активного стану громадянства. 3 одного боку, мислитель виокремлює ліберальну традицію природного права, яка бере свій початок від Дж. Локка й розвиває індивідуалістичноінструменталістське розуміння ролі громадянина, а з іншого - республіканську традицію, яка бере свій початок від вчення про державу Аристотеля, де 
формується комунікаційно-етичне тлумачення ролі громадянина [145, с. 348]. В першому випадку «громадянство окреслюється за зразком організаційного членства, яке встановлює правове становище людини, в іншому випадку належністю до самовизначеної етично-культурної спільноти» [145, с. 348].

Виокремлення двох політичних традицій, дає можливість Ю. Габермасу, показати їх вплив на специфіку політичної діяльності. 3 позиції першого, тобто ліберального підходу, «окрема людина є зовнішньою стосовно держави, у відтворення якої вона робить певний внесок, скажімо, у вигляді виборчого голосу чи сплати податку, для того, щоб отримати натомість успішне функціонування структури [держави]. Відповідно до іншого тлумачення, громадяни об’єднуються в політичну спільність як частини цілого настільки, що можуть витворити свою особисту і соціальну ідентичність лише в просторі загальних процесів і визнаних політичних інституцій» [145, с. 348$]$.

Громадяни мало чим відрізняються від приватних осіб, які частіше за все віддають перевагу своїм неполітичним інтересам в межах ліберальної політичної традиції. В межах республіканської традиції громадянство реалізується в процесі колективного самовизначення, оскільки, акцентуючи увагу на приватній користі, немає можливості досягти політичної автономності. В межах республіканської традиції, «інституції свободи, забезпечені конституційно-правовим чином, є цінністю лише настільки, наскільки звикле до політичної влади, привчене до неї населення бачить в їхньому існуванні перспективу самовизначення для себе» $[145$, c. 348$]$.

Беручи до уваги позицію Ю. Габермаса, можна стверджувати, що повноцінне громадянське суспільство, за умов панування республіканськодемократичної традиції, яку започаткували Кирило-Мефодіївці, зокрема, та народники загалом, побудувати практично неможливо, так як людина самовизначається і проявляє свободу тільки в певному колективному просторі, який, завдяки деяким культурним ознакам, визнається своїм. Очевидно, що саме з цієї причини, тривалий час в українській інтелектуальній думці ліберальні ідеї не знаходили грунту для свого розвитку. 
Попри те, що Кирило-Мефодіївці та народники загалом мали дуже мало спільних ідей із західноєвропейською ліберальною доктриною, Н. Гедікова вважає, що «ліберальний рух в Україні (у цілісній територіальній ії єдності), який став основною передумовою історичного розвитку, розвивався в умовах, стіснених між двома імперськими режимами, з обмеженою соціальною базою, яка не мала гідної підтримки ні з боку уряду, ні з боку народних мас, тому «агато положень класичного лібералізму були тут інтерпретовані відповідно до місцевих умов» [146, с. 84]. Лібералізм є космополітичною ідеологією освічених представників буржуазії, яка бореться спочатку за власні політичні права, а потім проти репресивності державного управління. Натомість українське соціальне життя першої половини XIX ст., визначалося кріпосною залежністю, яку можна назвати різновидом премодерних соціальних зв'язків 3 чітко вираженою ієрархічною структурою суспільства. Відповідно, суспільно-політична думка цього періоду зосередила свою увагу на формуванні народного «Ми», або ж «загальної волі» у визначенні Ж.-Ж. Руссо.

Перебільшеним здається і зауваження Н. Гедікової щодо того, що «з підготовкою і відміною кріпосного права, проведенням інших прогресивних реформ, лібералізм набув більш оформленого характеру, посилював свої ідейні позиції, став політичною течією, з якою вимушені були рахуватися» [146, с. 84]. Дослідниця зазначає, що головними ідеями прихильників ліберальної доктрини стали: політичні і громадянські свободи, культурно-просвітницька робота серед народу і ознайомлення його з європейською культурою; боротьба з імперською політикою царизму; розподіл влади; непорушність приватної власності; українське національне відродження і територіальна єдність України, іiі самостійність; створення громадянського суспільства і такого державного порядку, за якого усі суспільні інститути діяли би в інтересах особистості й переважної більшості тощо.

Більшість 3 виокремлених Н. Гедіковою характеристик українського лібералізму першої половини XIX ст., не мають нічого спільного $з$ ідеями класичного лібералізму. Головною суперечністю в цьому контексті $\epsilon$ 
національний вимір суспільно-політичної думки першої половини XIX ст. Лібералізм - це космополітична доктрина, яка $є$ необмеженою національними рамками. Немає жодних підстав розглядати зв'язок ліберальної доктрини із демократичними прагненнями чи характерним для українського руху за громадянські права широких народних мас чи територіальну єдність українців. Ці риси є співзвучними з ідеями Ж.-Ж. Руссо й, особливо, концептами загальної волі та суверенітету народу [159], між тим мають небагато спільного 3 ліберальною ідеєю свободи, яка, як зазначає А. де Токвіль, породжує тиранію спільноти, яка завжди намагається встановити дійсну рівність. Іншими словами, колективне самовизначення веде до добровільного поневолення індивіда, який приєднавшись до колективного «Ми» втрачає частину свободи. 


\section{SECTION 6. THE CIVIL PROCESS}

DOI 10.46299/ISG.2021.MONO.LEGAL.II-143-147

\section{1 Міжнародно-правові стандарти професійної діяльності адвоката в цивільному процесі України}

Обраний державою курс на європейську інтеграцію зумовлює необхідність впровадження в національні норми права законодавчих ініціатив, які стосуються специфіки професійної діяльності адвокатів, зокрема в цивільному процесі. Наразі у зв'язку з проведенням судової реформи інститут правової допомоги зазнає суттєвих змін. 3 огляду на це набуває актуальності дослідження міжнародного законодавства, яке регулює питання професійної діяльності адвокатів у цивільному процесі.

Впродовж останніх років в Україні проводиться активна діяльність 3 удосконалення правової допомоги, яка надається адвокатами у формі цивільного процесуального представництва.

Суб’єктами законодавчої ініціативи запропоновано внесення деяких змін до нормативно-правових актів, що стосуються професійної діяльності адвокатів [169-171]. Так, Указом Президента України від 20.05.2015 р. схвалено «Стратегію реформування судоустрою, судочинства та суміжних правових інститутів на 2015-2020 роки». У ній закріплюються основні положення щодо реформування надання правової допомоги в Україні та професійної діяльності адвокатів, а також приведення законодавства України у відповідність до європейських стандартів [172]. У зв'язку з цим можна погодитися з думкою В. О. Святоцької, яка, досліджуючи актуальні питання адвокатури України у світлі євроінтеграційних прагнень, наголошує, що з часів здобуття нашою країною незалежності адвокатура як важливий інститут правової системи держави перебуває у стані постійного реформування. Вона зазначає, що на долю української адвокатури випало чимало випробувань, адже законодавство стосовно неї постійно видозмінювалося, а їі становлення та розвиток завжди залежали від особливостей становлення самої держави та специфіки ії механізмів управління [173, с. 109]. 
У межах роботи заслуговує на увагу п. 5 ч. 1 Додатку до Резолюції (78) 8 Комітету міністрів Ради Європи «Про юридичну допомогу та консультації» від 02.03.1978 p., в якому закріплено, що юридична допомога завжди повинна здійснюватися особою, яка має право практикувати в якості адвоката відповідно до юридичних норм конкретної держави. У ньому також зазначається, що участь адвоката може бути як у разі, коли система юридичної допомоги передбачає це, так і у випадках, коли: а) сторони повинні бути представлені адвокатом у судовому органі конкретної держави відповідно до закону; б) є визначення з боку органу, який правомочний розглядати питання про надання юридичної допомоги того, що послуги адвоката є необхідними з огляду на конкретні обставини справи [175].

Ураховуючи вищенаведені положення, слід зазначити, що адаптація законодавства України стосовно виключного процесуального представництва адвокатом у суді є правильним кроком. У той же час в юридичній літературі положення, які викладені у Резолюції, не знайшли повної й беззаперечної підтримки. Так, С.С. Бичкова та А.В. Чурпіта, критично досліджуючи законодавчі зміни щодо інституту представництва в цивільному процесі, наголошують, що доцільним $є$ допуск в якості процесуальних представників не тільки адвокатів. Зазначені автори вважають, що варто допускати в якості процесуальних представників й інших осіб, які відповідають встановленим Законом вимогам [176, с. 27].

Важливі європейські стандарти професійної діяльності адвокатів закріплено у Кодексі поведінки європейських адвокатів. Зокрема, у ньому визначаються норми надання адвокатом різних видів правової допомоги 3 дотриманням принципів здійснення адвокатської діяльності (незалежності, довіри й особистої порядності, конфіденційності), розмірів та виплат гонорарів, правил поведінки адвокатів у суді та між собою. Особливе значення мають положення 5.8 Кодексу, що адвокати повинні підтримувати й розвивати свої професійні знання та навички з належним урахуванням авторитету своєї професії [177]. 
Не менш важливе значення для професійної діяльності адвокатів мають Загальні принципи для спільноти юристів, прийняті Міжнародною асоціацією юристів 20.09.2006 р. в м. Чикаго. У цьому документі відзначається, що юристи в усьому світі є професіоналами, які спеціалізуються з права, ставлять інтереси своїх клієнтів вище своїх власних і намагаються домогтися поваги до верховенства права [178].

Крім того, відповідно до Основних положень про роль адвокатів від 01.08.1990 р. останні, як важливі учасники здійснення правосуддя, мають постійно дбати про честь і гідність своєї юридичної професії [179]. Принципи діяльності адвокатів закріплено також і в іншому міжнародному документі від 07.09.1990 р., що стосується ролі юристів [180]. Наступним нормативним актом, який займає важливе місце в правовому регулюванні професійної діяльності адвокатів на теренах Свропейського Союзу, є Загальний кодекс правил від 01.10.1988 p. [181], у п. 1.1 якого закріплено, що у будь-якому правовому суспільстві адвокату відведено особливу роль, а його призначення не обмежено сумлінним виконанням свого обов'язку у межах закону. Адвокат має діяти в інтересах права в цілому так само, як і в інтересах тих, чиї права і свободи йому довірено захищати. Адвокат повинен не лише виступати в суді від імені клієнта, а й надавати йому юридичну допомогу у вигляді порад і консультацій. Поряд із цим даний документ ретельно врегулював питання щодо принципів адвокатської діяльності, зокрема щодо незалежності, довірчих відносин між клієнтом і адвокатом, конфіденційності діяльності та ін. Він містить також низку положень щодо особистої реклами адвоката та його взаємовідносини з клієнтами, судом, іншими адвокатами та ін. [181].

3 огляду на проведення в Україні правових реформ, а також специфіку надання адвокатами правової допомоги при захисті цивільних прав й охоронюваних законом інтересів, видається доцільним використання позитивного зарубіжного досвіду, закріпленого у вищенаведених міжнародних нормативно-правових документах. Разом із цим визначення єдиного напрямку реформування адвокатури в цивільному процесі зумовлено наявністю 
суперечливих пропозицій (законодавчих ініціатив) щодо концентрації повноважень представництва виключно адвокатами. У цьому аспекті варто зазначити, що Законом України «Про внесення змін до Конституції України (щодо правосуддя)» від 02.06.2016 р. Основний Закон України було доповнено новою статтею 131-2, де вказано, що виключно адвокат здійснює представництво іншої особи в суді, а також захист від кримінального обвинувачення [182].

Поряд із цим прийнятий 02.06.2016 р. Закон України «Про судоустрій i статус суддів» у змісті ст. 10 ч. 3 закріплює, що для надання професійної правничої допомоги діє адвокатура. Забезпечення права на захист від кримінального обвинувачення та представництво в суді здійснюється адвокатом, за винятком випадків, установлених законом [183].

На нашу думку, логічним кроком з наближення цивільного процесуального законодавства України, що регулює правовідносини надання кваліфікованої правової допомоги зацікавленим особам, зокрема щодо професійного представництва адвоката в цивільному процесі, до міжнародних стандартів професійної діяльності адвокатів, $є$ оновлення змісту Цивільного процесуального кодексу України (далі - ЦПК України) відповідно до наведених вище конституційних положень. 3 огляду на це науковцями пропонується доповнити ЦПК України новою статтею 401 «Адвокат як професійний представник у справі» в такій редакції: «Адвокат як професійний представник у цивільній справі - це особа, яка має повну вищу юридичну освіту, свідоцтво на право зайняття адвокатською діяльністю та здійснює діяльність 3 надання правової допомоги у цивільній справі на професійній основі, належним чином використовуючи власні повноваження. Адвокат, який бере участь у справі на стороні клієнта, може ініціювати укладення мирової угоди між сторонами. Адвокат може висловити намір про відмову від позову у разі, якщо він $\epsilon$ представником позивача, та про визнання позову у разі, якщо він $\epsilon$ представником відповідача. Повноваження адвоката, який представляє свого клієнта в суді, повинні бути посвідчені договором про надання правової 
допомоги або ордером чи довіреністю. Адвокат за вимогою суду повинен пред’явити своє посвідчення [169].

Адвокат як представник у цивільній справі повинен завжди сумлінно прагнути до досягнення максимально ефективного результату, якого потребує клієнт, дотримуючись правил, які встановлені цим Кодексом, Законом України «Про судоустрій і статус суддів», Законом України «Про адвокатуру та адвокатську діяльність» та іншим законодавством України». В обгрунтування пропонованої норми слід зазначити, що внесення вказаної статті до ЦПК України буде логічним результатом удосконалення процесуального законодавства, що належним чином співвідноситься 3 реформуванням професійної адвокатської діяльності, а також 3 міжнародними стандартами професійної діяльності адвокатів.

На основі аналізу міжнародних нормативних актів, що закріплюють положення стосовно професійної діяльності адвокатів, зокрема в цивільному процесі, до європейських стандартів професійної діяльності адвокатів запропоновано віднести такі: 1) надання правової допомоги виключно адвокатами; 2) достатню кваліфікацію та досвід адвокатів як професійних юристів; 3) конфіденційність і незалежність адвокатської діяльності; 4) адвокат, здійснюючи свою професійну діяльність з надання правової допомоги клієнту, повинен завжди діяти в інтересах останнього (у межах законодавства); 5) право адвоката на винагороду (гонорар) за здійснення професійної діяльності; 6) професійне страхування адвокатської діяльності з метою правового захисту адвоката; 7) підкорення адвоката, як професійного юриста, відповідним правилам (нормам законодавства), що регулюють питання етичної поведінки під час надання правової допомоги в судах; 8) порядність і чесність професійної адвокатської діяльності; 9) наявність духу корпоративності та взаємної підтримки між адвокатами; 10) повага до інтересів усіх учасників судового процесу; 11) застосування заходів процесуального примусу до адвокатів у разі вчинення ними правопорушень. 
DOI 10.46299/ISG.2021.MONO.LEGAL.II-148-153

\section{2 Поняття переговорів у контексті альтернативного розгляду спорів у цивільних справах}

Відповідно до Конституції Україна є демократичною правовою державою. Демократизація суспільства і його основних інститутів передбачає, що в певних випадках воно здатне самостійно вирішувати окремі види конфліктів, що виникають в процесі суспільних відносин. Сучасне законодавство і правозастосовна практика здатні надати цілий ряд альтернативних процедур захисту прав і законних інтересів учасників правовідносин, між якими виник правовий конфлікт. При цьому способи цього захисту можуть бути реалізовані в різних комбінаціях. Це дозволяє вирішувати виникаючі конфлікти набагато ефективніше, не витрачаючи зайвих тимчасових і матеріальних ресурсів.

В основі потреби в переговорах (negotiations) як самостійному вигляді альтернативного вирішення спорів - об'єктивна необхідність спільного погодженого вирішення питань, що представляють інтерес для учасників суспільних відносин.

Значення переговорів у всіх сферах життєдіяльності суспільства постійно зростає[184]. Як універсальний засіб спілкування, унікальний інструмент для вирішення спорів переговори забезпечують згоду, розвиток всебічного співробітництва і соціального партнерства, знімають напругу між сторонами, що знаходяться в стані конфлікту, впорядковують суспільні відносини і навіть у багатьох ситуаціях «дозволяють усунути небезпеку, попередити вчинення тяжких злочинів, уникнути застосування насильства». У цьому полягає соціальна і моральна цінність переговорів.

При інших альтернативних способах вирішення спорів, які $\epsilon$ не переговорними, а змагальними (арбітраж, третейський розгляд), значення переговорів менш виражено. Однак в літературі існує точка зору, в рамках якої навіть судовий процес розглядається як процес переговорів[185].

Конструкція алгоритму (послідовності) застосування способів вирішення юридичного конфлікту повинна містити переговори як один з перших способів 
досягнення згоди сторін. У разі неефективності застосування несудового дозволу юридичного конфлікту сторони або третя сторона вдаються до судочинства найпоширенішому способу вирішення юридичних конфліктів.

Переваги переговорів перед іншими альтернативними способами вирішення спорів можуть бути визначені в наступному: в їх процесі відбувається безпосередня взаємодія сторін; суб'єкти конфлікту мають можливість максимально контролювати різні аспекти своєї взаємодії, в тому числі самостійно встановлювати тимчасові рамки і межі обговорення, впливати на процес переговорів i ïx результат, визначати рамки угоди; переговори дозволяють суб'єктам конфлікту виробити угоду, що задовольняє кожну зі сторін i дозволяє уникнути тривалого судового розгляду, яке може закінчитися програшем однієї з них; специфіка взаємодії суб'єктів конфлікту на переговорах дозволяє зберегти конфіденційність[186].

Як зазначає М. Бове, в результаті переговорів, які він відносить до самоврядним способам врегулювання цивільно-правових спорів, сторони перетворюють правове протиріччя в протиріччя економічне, дозволяючи свій конфлікт на підставі конкретної норми, укладаючи угоду на підставі попередньої оцінки своїх економічних інтересів. Іншими словами, законодавець надає в розпорядження сторін переговорний інструмент, визначаючи можливі умови його використання, і таким інструментом $є$ цивільний кодекс, зокрема, загальна і особлива частини зобов'язального права. Користуючись свободою договору, сторони можуть на власний розсуд, погодивши свої волі, шляхом взаємних поступок щодо початкових позицій домовитися про вибір того чи іншого варіанту врегулювання конфлікту своїх економічних інтересів в встановлених законом рамках, уклавши ту чи іншу угоду. Рамки визначаються імперативними нормами, які задають умови визнання угоди недійсною. На думку М. Бове, якщо в результаті переговорів укладено угоду, то в такому рішенні конфлікту немає перемогла і сторони, що програла, оскільки це рішення не було прийнято суддею за боку. Звісно ж, проте, що це так, лише якщо обидві сторони діяли сумлінно 
під час переговорів і укладену за результатами переговорів підсумкову угоду не є для однієї зі сторін кабальної угодою[187].

Переговори є переважним методом приватного замовлення. В результаті виникають безліч прийомів ведення переговорів, які охоплюють різноманітні соціальні відносини. У своєму широкому розумінні, переговори - це процес спілкування, що передбачає досягнення згоди чи взаємодії для вирішення психологічного протистояння. Переговори стосуються політичних угод, комерційних операцій, переговорів про звільнення заручників, формування державних норм і правил, вирішення суперечливих проблем сім'ї та шлюбу, врегулювання громадських та екологічних проблем, i тому подібних. Відразу стає очевидним, що переговори $€$ надзвичайно гнучким та адаптованим процесом, який можна контекстуалізувати в різних соціальних ситуаціях.

Переговори завжди були пов’язані з адвокатами та правовою системою. Але ніколи до того переговори, що застосовуються в юридичній практиці, не були визначені як юридичні переговори - метод переговорів, який функціонує в рамках правового середовища відповідно до власних унікальних стандартів, цінностей та структури. Причина полягає в тому, що юридичні переговори мають місце одночасно з появою та розвитком системи ADR[188].

ADR надав основу, в якій діють різні значення та орієнтири, що могли збігатись i перехресно стосуватися одне одного щодо теорії та практики переговорів. Переговори є продуктом цього процесу. Через вплив ADR, переговори, як це відбулося в юридичній практиці, були переоцінені не лише 3 юридичної точки зору перспективи, але також на основі міждисциплінарних досліджень. Теоретики юридичних переговорів зверталися до соціальних, антропологічних, психологічних та соціологічних джерел, щоб зрозуміти процес переговорів, як це практикується в його правовому середовищі.

Уявлення про переговори закріплюється у всіх його аспектах та культурах, воно не є невизначеною та випадковою подією, яка використовується як спеціальна основа, але натомість має чіткі процесуальні характеристики. Отже, переговори $\epsilon$ структурованим процесом, який можна використовувати i 
раціонально ним керувати, оскільки він прогресує через низку заздалегідь визначених стадій, хоча і не відповідно до жорстких моделей. Через наголос на процесуальному характері переговорів їх можливо проаналізувати не тільки як процес, а й як юридичні моделі прийняття рішень.

Айзенберг[189] дослідив нормативні питання, що виникають в результаті аналізу розбіжностей між законодавством та рішенням, 3 одного боку, та переговори як неформальний процес прийняття рішень, з іншого боку. На цій підставі, це так можна розрізнити нормотворчі та трансакційні переговори як розширення законодавчої функції та ведення переговорів, як неформальна аналогія офіційного прийняття рішень. Розмежування є принциповим, оскільки воно контекстуалізує правові переговори, що стосуються або створення законних прав, або вирішення суперечок щодо законних прав. Переговори щодо прийняття прав стосуються майбутньої поведінки, поки переговори про суперечки стосуються суперечок, що виникли в результаті минулих подій.

Робота Айзенберга також порушує важливе питання про характер переговорів у контексті системи ADR. Різниця між переговорами щодо нормотворчості та переговорів про суперечки створюють нормативну основу для контекстуалізації двох форм переговорів. Переговори, як основний процес АРС, стосуються переговорів щодо суперечок. Як вказує їх назва, АРС зосереджене на вирішенні суперечок. Ні в якому разі значення переговорів щодо нормотворчості не є заниженим. Обидві форми переговорів є однаково важливими. Однак, як основний альтернативний процес вирішення спорів, переговори слід тлумачити як вирішення суперечок, незалежно від того, чи $є$ їх зміст законним чи неправовим. Тому конкретне значення визначає переговори як основний процес APC.

Поява системи ADR також призвела до критичної оцінки традиційної структури та стратегії юридичних переговорів. Звичайний конкурентний підхід до юридичних переговорів характеризується стандартною роботою[190] розробки методів принципових переговорів[191] та понять інтегративних переговорів[192]. Ці інноваційні підходи до переговорів представляють 
тенденцію, яка відходить від лінійної структури розподілу, характерної для юридичних переговорів у поєднанні з конкурентною стратегією.

Відповідь видно з юридичної літератури, що пішла далі. Кооперативна стратегія Уільямса набула видатного значення[193], підтверджуючи, що стратегія відрізняється від конкурентної, може застосовуватися в рамках змагальної структури юридичних переговорів. Так само, було застосовано інтегративну стратегію на основі моделі вирішення проблем розроблену i впроваджену Менкель-Медоу[194]. 3 різних точок зору, Ловенталь[195] та Гіфорд[196] забезпечують раціональні підстави для вибору стратегії щодо правових переговорів.

У роботах Мнукіна та Корнхаузера[197] мало спільного 3 теорією переговорів, але одна ідея, яку вони висловили, зробила їх роботу відомою. Переговори, що стосуються юридичного спору, відбуваються «в тіні закону», створюючи тим самим переговорний фонд для учасників спору. «Тінь закону» звужує значення переговорів як основного процесу АРС щоразу, коли застосовується в правовому середовищі. Окрім того, вона розуміється як форма переговорів про суперечки, особливий тип переговорів, який можна охарактеризувати як «юридичні переговори» та є продуктом концепції «тіні закону». Ця коротка фраза інкапсулює саму суть переговорів, що відбуваються на тлі юридичних процесів. Юридичні переговори передбачають результат у вигляді винесеного рішення, тим самим запроваджуючи прецедентне, матеріальне право, докази, а також властиві затримки у судовому процесі, його невизначений результат та його непомірні трансакційні витрати, як фактори, що безпосередньо впливають на суть переговорів.

Поняттю юридичних переговорів дали цікаве визначення Кріцер[198] i Галантер[199]. Працюючи з припущенням, що більшість юридичних суперечок врегульовані переговорами, ці автори зазначають, що переконлива присутність судів представляє альтернативу рішення, якщо переговори не проваляться. Ця ідея провокує думку про мету та функцію переговорів як основного вирішення процесуальних суперечок в системі ADR та вказує шлях для подальших 
досліджень щодо взаємозв'язку між юридичними переговорами та судовим рішенням.

Вчення цих авторів, полягає у тому, що переговори - це не випадкова соціальна сфера, подія або нечіткий спосіб спілкування. Переговори мають форму мистецтва та наукову форму. У цій формі можна виділити певні процесуальні етапи, розмежувати певні форми переговорів, визнати їх потенціал як метод вирішення проблеми та проаналізувати хід їх проведення шляхом відбору різних стратегій. Через свою популярність цього методу вирішення спорів, підвищену увагу було зосереджено на ролі та функції процесу переговорів, як вони застосовуються в правовому контексті. Насправді переговори про трудові відносини чи будь-яке інше контекстне застосування можуть бути обрані як не юридичні переговори. У кожному випадку цей спеціалізований контекст певної форми переговорів, який пов'язаний 3 теоретичною моделлю переговорів. Все це дає нам можливість дослідити безперервність між переговорами як неформальним процесом із юридичними переговорами. 


\section{SECTION 7. THE CRIMINAL PROCESS}

DOI 10.46299/ISG.2021.MONO.LEGAL.II-154-163

\subsection{Special features of the criminal provision of the attorney general}

Всі громадяни мають рівні конституційні права і свободи та є рівними перед законом. Відповідно до ч. 1, 2 ст. 24 Конституції України не може бути привілеїв чи обмежень за ознаками раси, кольору шкіри, політичних, релігійних та інших переконань, статі, етнічного походження, майнового стану, місця проживання, за мовними або іншими ознаками. Проте, кримінальний процесуальний закон встановлює особливості провадження щодо окремої категорії осіб (глава 37 КПК України).

Особливий порядок кримінального провадження здійснюється стосовно осіб, зазначених у ст. 480 КПК України (далі КПК), зокрема, Генерального прокурора. Окрім КПК, особливості притягнення до кримінальної відповідальності Генерального прокурора визначаються Конституцією України, Законом України «Про прокуратуру» від 14.10.2014 р., Законом України «Про Регламент Верховної Ради України» від 10.02.2010 р., Законом України «Про Вищу раду правосуддя» від 21.12.2016 р., та відповідними підзаконними актами: Положенням про порядок роботи Кваліфікаційно-дисциплінарної комісії прокурорів від 27. 04. 2017 р., Положенням про Раду прокурорів України від 27. 04. 2017 р., Регламентом Вищої Ради Правосуддя від 24. 01. 2017 р. № 52/0/15-17 та ін.

Визначальними рисами особливого порядку кримінального провадження є: особливі порядки застосування затримання та/або запобіжного заходу, повідомлення про підозру, підслідності досудового розслідування, відсторонення Генерального прокурора від посади, підсудності судового розгляду, звільнення Генерального прокурора з посади. 
1. Конституційно-правовий статус Генерального прокурора.

Конституційно-правовий статус Генерального прокурора законодавець розкриває в Конституції України, Законі України «Про прокуратуру», Законі України «Про Регламент Верховної Ради України» та деяких інших правових актах. Згідно зі ст.131-1 Конституції України Генеральний прокурор очолює прокуратуру. Відповідно до п. 25 ч. 1 ст. 85 Конституції України, ст. 40 Закону України «Про прокуратуру», ст. 212 Закону України «Про Регламент Верховної Ради України» Генеральний прокурор призначається на посаду Президентом України за згодою Верховної Ради України (далі ВР України) на 6 років і одна й та ж особа не може обіймати цю посаду два строки поспіль. Рішення про надання згоди ВР України на призначення на посаду та звільнення з посади Президентом України Генерального прокурора приймається відкритим поіменним голосуванням більшістю голосів народних депутатів від конституційного складу ВР України і оформляється відповідною постановою ВР України. Відповідно до п. 25 ч. 1 ст. 85 Конституції України, ст. 213 Закону України «Про Регламент Верховної Ради України» ВР України може висловити недовіру Генеральному прокуророві, що має наслідком його відставку з посади. Ст. 40 Закону України «Про прокуратуру» встановлює загальні вимоги для Генерального прокурора: Генеральним прокурором може бути фізична особа, яка має вищу юридичну освіту та стаж роботи в галузі права не менше 10 років; 2) володіє державною мовою; 3) має високі морально-ділові, професійні якості та організаторські здібності; 4) стосовно якого відсутні обставини, передбачені ч. 6 ст. 27 Закону України «Про прокуратуру», відповідно до якої не може бути прокурором будьякого рівня особа, яка: 1) визнана судом обмежено дієздатною або недієздатною; 2) має захворювання, що перешкоджає виконанню обов'язків прокурора; 3) має незняту чи непогашену судимість або на яку накладалося адміністративне стягнення за вчинення правопорушення, пов'язаного з корупцією. Ст. 18 Закону України «Про прокуратуру» визначає, що діяльністю, несумісною $з$ діяльністю прокурора будь-якого рівня, є: 1) обіймання посади в будь-якому органі державної влади, іншому державному органі, органі місцевого самоврядування 
та представницький мандат на державних виборних посадах; 2) порушення обмежень щодо сумісництва та суміщення 3 іншими видами діяльності, визначених Законом України «Про запобігання корупції»; 3) належність до політичної партії, участь у політичних акціях, мітингах, страйках. Вимоги щодо несумісності з діяльністю прокурора, передбачені ч. 1 ст. 18 Закону України «Про прокуратуру», не поширюються на участь прокурорів у діяльності виборних органів релігійних та громадських організацій. Відповідно до ч. 2 ст. 53 Закону України «Про прокуратуру», п. 11.9 Регламенту Вищої Ради Правосуддя в разі порушення Генеральним прокурором вимог щодо несумісності Вища рада правосуддя вносить подання про звільнення Генерального прокурора 3 посади Президенту України. Оскільки посада Генерального прокурора є адміністративною посадою, то відповідно до п. 5 ч. 3 ст. 40, ч. 6 ст. 39 Закону України «Про прокуратуру» його не може бути призначено, якщо він має заборгованість зі сплати аліментів на утримання дитини, сукупний розмір якої перевищує суму відповідних платежів за 6 місяців 3 дня пред'явлення виконавчого документа до примусового виконання. У випадку визнання Генерального прокурора винним у вчиненні адміністративного правопорушення, пов’язаного з корупцією, Кваліфікаційнодисциплінарна комісія прокурорів вносить подання про звільнення Генерального прокурора з посади Президенту України відповідно до ч. 2 ст. 54 Закону України «Про прокуратуру».

Відповідно до ст. 9 Закону України «Про прокуратуру» Генеральний прокурор має наступні повноваження: 1) представляє прокуратуру у зносинах 3 органами державної влади, іншими державними органами, органами місцевого самоврядування, особами, підприємствами, установами та організаціями, а також прокуратурами інших держав та міжнародними організаціями; 2) організовує діяльність органів прокуратури України, визначає межі повноважень Офісу Генерального прокурора, обласних та окружних прокуратур у частині виконання конституційних функцій; 3) призначає прокурорів на адміністративні посади та звільняє їх з адміністративних посад у випадках та порядку, 
встановлених цим Законом; 4) у встановленому порядку на підставі рішення відповідного органу про притягнення до дисциплінарної відповідальності прокурора приймає рішення про застосування до прокурора Офісу Генерального прокурора, прокурора обласної прокуратури дисциплінарного стягнення або про неможливість подальшого перебування такої особи на посаді прокурора; 5) призначає на посади та звільняє 3 посад прокурорів Офісу Генерального прокурора у випадках та порядку, встановлених цим Законом; 6) здійснює розподіл обов’язків між першим заступником та заступниками Генерального прокурора; 7) затверджує акти з питань щодо внутрішньої організації діяльності органів прокуратури; 7-1) затверджує стратегію розвитку прокуратури; 7-2) затверджує положення про систему індивідуального оцінювання якості роботи прокурорів та систему оцінювання якості роботи прокурорів; 7-3) затверджує порядок вимірювання та регулювання навантаження на прокурорів; 8) забезпечує виконання вимог щодо підвищення кваліфікації прокурорів Офісу Генерального прокурора; 9) затверджує загальні методичні рекомендації для прокурорів з метою забезпечення однакового застосування норм законодавства України під час здійснення прокурорської діяльності; 9-1) за поданням Генеральної інспекції направляє матеріали до Державного бюро розслідувань; 92) визначає порядок розгляду звернень щодо неналежного виконання прокурором, який обіймає адміністративну посаду, посадових обов’язків, встановлених для відповідної адміністративної посади; 10) виконує інші повноваження, передбачені цим та іншими законами України. Відповідно до ч. 5 ст. 8-1 Закону України «Про прокуратуру» він здійснює безпосереднє керівництво керівником Спеціалізованої антикорупційної прокуратури. Ч. 6 ст. 19 Закону України «Про прокуратуру» зобов’язує усіх прокурорів: 1) виявляти повагу до осіб під час здійснення своїх повноважень; 2) не розголошувати відомості, які становлять таємницю, що охороняється законом; 3) діяти лише на підставі, в межах та у спосіб, що передбачені Конституцією та законами України; 4) додержуватися правил прокурорської етики; 5) щорічно проходити таємну перевірку доброчесності. Ст. 6 Закону України «Про прокуратуру» зобов’язує 
Генерального прокурора щороку до 1 квітня подавати до ВР України звіт про діяльність прокуратури, який містить інформацію про: 1) статистичні та аналітичні дані щодо виконання функцій, покладених на прокуратуру; 2) фактичну чисельність органів прокуратури; 3) забезпечення незалежності прокурорів, зокрема кількість повідомлень про загрозу незалежності прокурора, які надійшли до Ради прокурорів України, та інформацію щодо прийнятих за такими повідомленнями рішень; 4) забезпечення законності та доброчесності у діяльності прокуратури, зокрема кількість: перевірок доброчесності прокурорів, проведених підрозділами внутрішньої безпеки, та інформацію щодо прийнятих за такими перевірками рішень; проведених службових розслідувань, інформацію щодо приводів і підстав для їх призначення та проведення і щодо прийнятих рішень за результатами проведення таких службових розслідувань; звернень та судових справ щодо відшкодування державою шкоди, завданої незаконними рішеннями, діями чи бездіяльністю прокурора, та розмір такої шкоди, відшкодований державою за звітний період; судових справ щодо зворотної вимоги держави до прокурорів та сума коштів, витребувана за задоволеними судом зворотними вимогами держави; дисциплінарних скарг щодо прокурорів, інформацію щодо прийнятих рішень за результатами розгляду таких скарг; рішень про наявність дисциплінарних проступків прокурорів та про накладені (застосовані) дисциплінарні стягнення; 5) кошториси органів прокуратури та їх виконання; 6) забезпечення діяльності органів прокурорського самоврядування; 7) відомості, зазначені у п. п. 1-5 ч. 2 даної статті щодо діяльності Спеціалізованої антикорупційної прокуратури; 8) інші відомості, що стосуються результатів діяльності прокуратури. Генеральний прокурор особисто звітує про діяльність органів прокуратури перед ВР України на ії пленарному засіданні.

2. Гарантії незалежності Генерального прокурора.

Гарантії незалежності Генерального прокурора - один із ключових статусних елементів організації прокуратури. Добровольський Д. М. зазначає, що Генеральний прокурор відіграє важливу роль у функціонуванні 
прокурорської системи, а, отже, питання забезпечення його незалежності тісно пов’язане з реалізацією засади незалежності прокуратури в цілому. Ст. 16 Закону України «Про прокуратуру» передбачає наступні гарантії незалежності прокурорів усіх рівнів: 1) особливим порядком його призначення на посаду, звільнення 3 посади, притягнення до дисциплінарної відповідальності; 2) порядком здійснення повноважень, визначеним процесуальним та іншими законами; 3) забороною незаконного впливу, тиску чи втручання у здійснення повноважень прокурора; 4) установленим законом порядком фінансування та організаційного забезпечення діяльності прокуратури; 5) належним матеріальним, соціальним та пенсійним забезпеченням прокурора; 6) функціонуванням органів прокурорського самоврядування; 7) визначеними законом засобами забезпечення особистої безпеки прокурора, членів його сім’ї, майна, а також іншими засобами їх правового захисту. Ця стаття надає будьякому прокурору право звернутися 3 повідомленням про загрозу його незалежності до Ради прокурорів України, яка зобов'язана невідкладно перевірити і розглянути таке звернення за його участю та вжити в межах своїх повноважень, передбачених цим Законом, необхідних заходів для усунення загрози. Ст. 3 даного Закону гарантує захист незалежності прокурорів шляхом застосування гарантій від незаконного політичного, матеріального чи іншого впливу на прокурора щодо прийняття ним рішень при виконанні службових обов’язків та внаслідок політичної нейтральності прокуратури. Відповідно до ч. 4 ст. 49 даного Закону до Генерального прокурора не може бути застосовано дисциплінарне стягнення у виді рішення про неможливість подальшого його перебування на посаді.

3. Порядок затримання Генерального прокурора та застосування до нього запобіжних заходів.

Відповідно до ч. 2 ст. 176 КПК затримання особи є тимчасовим запобіжним заходом, тому стосовно Генерального прокурора воно має ту ж особливість, що i інші запобіжні заходи. Особливістю порядку затримання Генерального прокурора та застосування до нього запобіжних заходів є зобов’язання органу 
або посадової особи, які затримали Генерального прокурора або застосували до нього запобіжний захід, виконати вимогу, яка передбачена п. 2 ч. 1 ст. 483 КПК, а саме - повідомити про застосування запобіжного заходу органи і службові особи, які його призначили чи відповідають за заміщення його посади. Це стосується усіх видів запобіжних заходів та усіх видів затримання, які зазначені у КПК. 3 урахуванням процедури призначення Генерального прокурора такими службовими особами є президент України та депутатський корпус ВР України. Відповідно до ч. 3 ст. 9 Закону України «Про прокуратуру» у разі відсутності Генерального прокурора його повноваження здійснює перший заступник Генерального прокурора, тому він повідомляється теж. Оскільки відповідно до ст. 63 даного Закону Президент України видає указ про звільнення Генерального прокурора з посади на підставі та в межах подання відповідного органу, що здійснює дисциплінарне провадження щодо прокурорів, (а цим органом $є$ Кваліфікаційно-дисциплінарна комісія прокурорів), чи Вищої ради правосуддя, то Кваліфікаційно-дисциплінарна комісія прокурорів і Вища рада правосуддя впливають на заміщення посади Генерального прокурора. Тому Кваліфікаційнодисциплінарна комісія прокурорів і Вища рада правосуддя повідомляються теж. Кримінальні правопорушення, які вчиняються Генеральним прокурором, поділяються на 2 види: (а) ті, які Генеральний прокурор вчиняє поза межами своєї професійної діяльності, (б) ті, що пов'язані з його службовим статусом. До другого виду належать усі кримінальні правопорушення, які передбачені в Розділі XVII КК України та кримінальні правопорушення, які передбачені ст.. ст.. 371, 372, 373, 374, 380, 381, 382, 387, 397 КК України. Необхідно враховувати, що кримінальні правопорушення, які передбачені ст.ст. 381, 387 КК України, за своїм змістом співпадають із дисциплінарним проступком, який передбачено п.3 ч. 1 ст. 43 Закону України «Про прокуратуру», i їх розмежування проводиться на підставі оцінки наслідків, які були викликані діянням Генерального прокурора. Ч. 5 даної статті визнає дисциплінарним проступком вчинення дій, що порочать звання прокурора і можуть викликати сумнів у його об'єктивності, неупередженості та незалежності, у чесності та непідкупності органів 
прокуратури, до таких дій належить вчинення кримінальних правопорушень. Також із ч. 2 ст. 43 Закону України «Про прокуратуру» випливає можливість кваліфікації одного і того ж діяння Генерального прокурора і як кримінального правопорушення, і як дисциплінарного проступку.

4. Порядок повідомлення Генерального прокурора про підозру.

П. 4 ч. 1 ст. 481 КПК встановлює, що письмове повідомлення Генеральному прокурору про підозру повинно бути здійснено заступником Генерального прокурора. Оскільки дієслово «здійснено» охоплює увесь процес, то складення і вручення повідомлення про підозру Генеральному прокурору $є$ справою заступника Генерального прокурора. Однак ч. 2 ст. 481 КПК дозволяє заступнику Генерального прокурора доручити іншим прокурорам здійснити письмове повідомлення про підозру Генеральному прокурору у порядку, передбаченому ч. ч. 1, 2 ст. 278 КПК. Інші варіанти складення, вручення повідомлення Генеральному прокурору про підозру роблять це повідомлення нікчемним.

5. Порядок проведення стосовно Генерального прокурора оперативнорозшукових заходів чи слідчих дій під час досудового розслідування.

Особливістю порядку проведення стосовно Генерального прокурора оперативно-розшукових заходів чи слідчих дій під час досудового розслідування $\epsilon$ здійснення досудового розслідування кримінальних правопорушень, вчинених Генеральним прокурором, слідчими органами Державного бюро розслідувань відповідно до п. 1 ч. 4 ст. 216 КПК. У випадку вчинення Генеральним прокурором кримінальних правопорушень, передбачених статтями 191, 206-2, 209, 210, 211, 354 (стосовно працівників юридичних осіб публічного права), 364, 366-2, 366-3, 368, 368-5, 369, 369-2, 410 КК України детективи Національного антикорупційного бюро України (далі НАБУ) здійснюють досудове розслідування відповідно до абз. 6 п. 1 ч. 5 ст. 216 КПК. При визначенні органу, що здійснюватиме досудове розслідування у формі дізнання, застосовуються 
правила підслідності, передбачені ст. 216 КПК, тобто кримінальне провадження у формі дізнання стосовно Генерального прокурора проводиться слідчими органами Державного бюро розслідувань.

6. Порядок відсторонення Генерального прокурора від посади.

Окремим питанням постає порядок відсторонення Генерального прокурора від посади, воно застосовується щодо особи, яка підозрюється або обвинувачується у вчиненні злочину, відповідно до ч. 1 ст. 154 КПК. Згідно зі ч. 3 даної статті питання про відсторонення від посади Генерального прокурора вирішується Президентом України на підставі клопотання прокурора в порядку, встановленому законодавством. Відповідно до п. 5 ч. 1 ст. 64 Закону України «Про прокуратуру» повноваження Генерального прокурора зупиняються в разі відсторонення від посади в порядку, передбаченому ст. 154 КПК - до скасування заходу забезпечення кримінального провадження у вигляді відсторонення від посади чи відповідної ухвали або припинення дії такої ухвали.

7. Порядок судового розгляду кримінальної справи щодо Генерального прокурора.

Особливість порядку судового розгляду кримінальної справи щодо Генерального прокурора визначає ст. 33-1 КПК, відповідно до якої у випадку вчинення Генеральним прокурором корупційних кримінальних правопорушень, передбачених в примітці ст. 45 КК України, ст. ст. 206-2, 209, 211, 366-2, 366-3 КК України, кримінальні провадження стосовно цих кримінальних правопорушень підсудні лише Вищому антикорупційному суду.

8. Звільнення Генерального прокурора 3 посади внаслідок набрання законної сили обвинувальним вироком суду щодо Генерального прокурора.

Відповідно до ч. 2 ст. ст. 56 Закону України «Про прокуратуру» суд, який ухвалив обвинувальний вирок щодо генерального прокурора, після набрання таким вироком законної сили повідомляе про це Кваліфікаційно-дисциплінарну 
комісію прокурорів, яка вносить подання про звільнення Генерального прокурора $з$ посади Президенту України. Далі відповідно до ч. ч. 1, 2 ст. 63 даного Закону Президент України видає указ про звільнення Генерального прокурора $з$ посади на підставі подання Кваліфікаційно-дисциплінарної комісії прокурорів, подає до ВР України письмове подання про надання згоди на звільнення з посади Генерального прокурора. Відповідно до п. 8 ст. 212 Закону України «Про Регламент Верховної Ради України» рішення про надання згоди BP України на звільнення 3 посади Президентом України Генерального прокурора оформляється відповідною постановою ВР України. Відповідно до ч. 2 ст. ст. 63 Закону України «Про прокуратуру» повноваження Генерального прокурора припиняються з дня набрання чинності постановою Верховної Ради України. Відповідно до ст. 20 Закону України «Про прокуратуру» держава відшкодовує шкоду, завдану незаконними рішеннями, діями чи бездіяльністю Генерального прокурора. Держава, відшкодувавши шкоду, завдану вчиненим Генеральним прокурором кримінальним правопорушенням, має право зворотної вимоги до нього в розмірі виплаченого відшкодування. 
DOI 10.46299/ISG.2021.MONO.LEGAL.II-164-170

\section{2 До питання про можливості використання криміналістичного аналізу в розслідуванні злочинів (на прикладі серійних сексуально-садистських вбивств)}

Здатність до аналізу не слід змішувати з простою винахідливістю, бо аналітик завжди винахідливий, тоді як не всяка винахідлива людина здатна до аналізу. Едгар Аллан По

Серед численних видів вбивств найбільшу суспільну небезпеку представляють саме серійні сексуальні (або сексуально-садисьські) вбивства, які вчиняються протягом тривалого часу (роки, десятиліття), та супроводжуються тортурами і катуванням жертв, що входить до своєрідного обов'язкового «ритуалу» злочинців. Кількість їх жертв обчислюється десятками і сотнями. Окрім цього, небезпека вказаних злочинів полягає в тому, що серійні вбивці у зв'язку із наявністю у них певних психопатологій продовжують своє «полювання» все життя і не здатні зупинитися самі.

Вказані та інші особливості серійних сексуальних вбивств, у тому числі відсутність видимого зв'язку між злочинцем і його жертвами, роблять неефективною застосування традиційної методики розслідування вбивств. Одним лише вивченням способу життя жертви та іï оточення розкрити ці злочини неможливо. Серійні вбивці-маніяки вибирають жертви лише тільки за ним самим відомими ознаками. Відповідно іншими мають бути і шляхи встановлення злочинців і методи розслідування.

Не викликає сумнівів, що у діяльності слідчого немає і не може бути місця поняттю «дрібниця». Будь-яка дрібна деталь, незалежно від того, чи є вона матеріального (предмет, річ, їх частини тощо) або іншого походження (інформація або будь-які дані про людину, їі психологічні та характерологічні особливості, звички та ін.) може стати відправною точкою для висування, перевірки або спростування версії, обрання вірного напряму розслідування або вирішальним доказом у кримінальному провадженні/справі. Саме тому потрібно вчитися розпізнавати можливі зачіпки, якими б незначними та малоймовірними 
вони на перший погляд не видавалися, ретельно їх досліджувати, творчо підходити до можливостей їх використання з метою встановлення усіх обставин злочину.

Зокрема, для вирішення проблем різної складності, що виникають в процесі розкриття i розслідування злочинів, використовується метод криміналістичного аналізу [214, с. 341].

Останніми роками науково-технічний прогрес йде стрімкими темпами: з'являються нові технічні засобі, технології, а з ними можливості передачі та обробки інформації. Злочинці активно використовують вказані можливості в своїй діяльності, що становить певні труднощі для правоохоронних органів. Проте, науково-технічний прогрес є надбанням усього людства, тому він також відкриває нові можливості у боротьбі зі злочинністю: поява нових засобів i способів виявлення, фіксації, вилучення слідів злочину і злочинця, речових доказів, і використання їх в доказуванні у кримінальному провадженні.

Однак, поряд з надбаннями науково-технічного прогресу, важливими i незамінніми залишаються перевірені часом методи роботи слідчих. Одним 3 них є криміналістичний аналіз, який, на нашу думку, можна визнати одним з тактикокриміналістичних засобів і важливою складовою тактико-криміналістичного забезпечення розслідування злочинів [215, с. 64].

Криміналістичний аналіз (далі - КА) завжди був, $є$ й надалі залишатиметься у арсеналі методів діяльності слідчого. Власне, 3 нього і розпочинається будь-яке розслідування, оскільки усталений вираз «вивчення матеріалів» кримінальної справи/провадження не обходиться без аналізу усієї наявної інформації, визначення мети і напрямів подальших дій тощо.

Поле застосування КА у правоохоронній діяльності доволі широке. Він є одним з ефективних методів роботи та інструментів слідчого: достатньо простий у використанні, такий, що завжди перебуває при слідчому, який має бути готовим до його належного застосування для встановлення усіх обставин події злочину. Аналітичні здібності слід визнати професійно необхідними якостями слідчого, без яких його розслідування будуть страждати на неповноту. 
Саме за допомогою криміналістичного аналізу матеріалів кримінальної справи/провадження виявляються недоліки розслідування: як окремої або декількох слідчих (розшукових) дій, тактичної операції, оперативно-розшукових заходів, так і організації розслідування в цілому. Розкриття злочину «слідчим шляхом» не обходиться без криміналістичного аналізу слідчим усіх матеріалів справи/кримінального провадження, повноти та якості проведення слідчих дій, їх результатів, отриманих доказів, наявної криміналістично значущої інформації.

За належного проведення результати криміналістичного аналізу можуть стати відправною точкою у розкритті злочинів і встановленні злочинців. Даний метод $є$ ефективним і має застосовуватися у кожному розслідуванні. Проте, особливо важливе значення належне його застосування набуває при розслідуванні нерозкритих злочинів минулих років, по яких КА $є$ одним 3 основних методів і з якого власне й розпочинається ця робота.

Наочніше ефективність застосування КА можна побачити на при розслідуванні серійних та серійних сексуальних (або сексуально-садистських) вбивств. Останні у своїй більшості належать до категорії «злочини минулих років», оскільки вчиняються протягом тривалого часу (місяці, роки, десятиліття) та розкриваються найчастіше випадково, через помилки злочинців, «дрібниць» при їх розслідуванні не буває. Натомість, у практиці розслідування вказаних злочинів найчастіше саме через результати докладного КА розслідування виходило на вірний напрям.

Так, наприклад, «прорив» у розслідуванні справи Міхасевіча («вітебський душитель», 36 доведених слідством вбивств) став можливим передусім завдяки аналітичним здібностям слідчого Миколи Ігнатовича, який докладно вивчив кримінальні справи про вбивства жінок в області, належним чином проаналізував наявну інформацію і зробив правильний висновок, що усі злочини вчинено однією особою. Після чого М. Ігнатович домігся об'єднання усіх кримінальних справ в одне провадження, після чого розшук злочинця набув організованого характеру і привів до встановлення і затримання серійного вбивці. (Зазначимо, що до затримання Міхасевіча за скоєні ним вбивства було засуджено 
14 чоловік: один з яких був страчений, інший - засуджений на 15 років позбавлення волі, відсидів 6 років і осліп, після чого був звільнений як особа, що не становить небезпеки для суспільства, четверо осіб провели в місцях позбавлення волі більше 10 років).

Більше того, ще до практичного застосування для розшуку серійних вбивць «психологічного портрету» (вперше у СРСР був використаний при розслідуванні злочинів Чікатіла лікарем-психіатром О. О. Бухановським), також шляхом аналізу матеріалів кримінальної справи, отриманих оперативних даних $\mathrm{i}$ повідомлень громадян слідчий власноруч склав приблизний портрет серійного маніяка (його зовнішність, род занять, наявність автівки, причетність до правоохоронних органів), який згодом повністю збігся з образом Міхасевіча.

У подальшому також шляхом аналізу матеріалів справи, оперативних та інших даних слідчий М. Ігнатович вдруге попередив ймовірну слідчу помилку, зрозумівши, що злочинець намагається відвернути увагу правоохоронних органів від Полоцька, де мешкав і працював, надіславши листа від «патріотів Вітебська», та зосередив увагу оперативно-слідчих груп саме на цьому місті.

Слідча практика розслідування злочинів даної категорії містить достатньо прикладів результативного застосування криміналістичного аналізу.

Так, аналітичні здібності та практичний досвід керівника слідчої групи I. М. Костоєва привели до успіху у справі Чікатіла. Криміналістичний аналіз злочинів О. Кузнєцова дозволив встановити важливу особливість серійного вбивці, який дотримувався певного стереотипу при виборі своїх жертв. Вказана обставина була врахована при організації та проведенні оперативно-розшукових заходів.

На жаль, достатньо і недоліків, пов'язаних із неналежним застосуванням вказаного методу. В обвинувальному висновку по справі Головкіна було, зокрема, зазначено, що «...на початковому етапі справи розслідувалися розрізнено, без врахування конкретної обстановки, оцінки доказів і аналізу (виділено нами - О.А., В.Ж.) наявних даних...Висновки слідчо-оперативних 
працівників були засновані на припущеннях або аналогії наявної практики розкриття тяжких злочинів...що ускладнило пошук злочинця» [216, с. 266-267].

Видається, що найбільш важливе значення КА при розслідуванні серійних сексуально-садистських вбивств полягає у тому, що, окрім організаційного та пізнавального аспекту (встановити необхідність і послідовність проведення слідчих дій, оперативно-розшукових заходів тощо), цей метод дозволяє побачити усі недоліки та помилки, допущені при розслідуванні, та визначити заходи і засоби щодо їх усунення та попередження у подальшому. Для цього слід знати про КА, розуміти його значення та місце у встановленні обставин події, і належним чином ним володіти.

Для ефективного здійснення вказаного методу, окрім практичного досвіду, залежно від категорії злочину, напряму та мети застосування, бажаних результатів, слідчому, працівникам оперативних підрозділів, експертам, прокурорам (процесуальним керівникам) потрібно мати певні, у тому числі спеціальні, знання. Серійним сексуально-садистським вбивствам притаманні особливості, що відрізняють їх від інших вбивств, у тому числі вчинених 3 сексуальних мотивів. Діяльність по їх розкриттю та розслідуванню також має здійснюватися по-іншому, 3 врахуванням вказаних особливостей. Це ж стосується й криміналістичного аналізу. Правильно зазначається, що «методологічну основу криміналістичного аналізу складають знання кримінології, кримінального права, теоретичних основ криміналістики» [217, с. 52].

Все вищенаведене дає підстави для певних висновків.

3 метою успішного вирішення завдань розслідування слід використовувати всі наявні і доступні інструменти/методи. При цьому слід враховувати, що найчастіше за все слідчий при аналізі наявної інформації по справі використовує власний досвід розслідування. Однак, його особистий досвід завжди обмежений лише кількістю самостійно розслідуваних злочинів та особистісними якостями слідчого. Тому при розслідуванні складних справ поряд 
3 методами суб'єктивного аналізу необхідно застосовувати інші методи наукового пізнання [218, с. 267-268].

Можна визнати за позитивне, за певний прорив, що нарешті визнано за необхідне впровадження сучасних аналітичних технологій, у тому числі кримінального аналізу, у практику діяльності правоохоронних органів, зокрема, щодо розкриття та розслідування злочинів. Однак, слід враховувати, що попри наявність інтересу до кримінального аналізу, який виник порівняно нещодавно, вказана діяльність потребує наявності фахівців-аналітиків, яких слід підготувати, навчити усім тонкощам такої роботи, забезпечити відповідними технічними засобами, програмним забезпеченням.

Також необхідно мати на увазі, що кримінальний аналіз спрямований на перспективу, його процедура потребує зусиль багатьох людей і певного часу, так само як і отримані результати повинні бути належним чином і правильно інтерпретовані фахівцями, щоб бути в подальшому успішно використані на практиці. Надалі слід оцінити результати практичного застосування, виявити його можливі слабкі сторони та поміркувати над цим.

Слід також враховувати існуючі проблеми з підготовкою таких фахівціваналітиків, розробкою відповідного програмного і методичного забезпечення, часу, який потрібен на те, щоб створити дієву та ефективну систему кримінального аналізу, запустити іï в дію, апробувати на практиці, оцінити отримані результати, використати їх належним чином і з успіхом.

Тому, попри важливість використання інших, сучасних і таких, що довели свою ефективність у діяльності правоохоронних органів інших країн аналітичних методів і методик у боротьбі зі злочинністю, разом з тим слід використовувати апробовані вітчизняною слідчою практикою методи, які в разі правильного їх застосування також можуть привести до успіху в розкритті та розслідуванні злочинів. До того ж вони є достатньо простими у застосуванні і не потребують інших здібностей, окрім аналітичних, як от криміналістичний аналіз.

Звичайно, що використання вказаних інструментів/методів потребує обізнаності та ознайомлення з їх можливостями, наявності необхідної літератури, 
методичних рекомендацій і доступу до них усіх практичних працівників, кому доводиться займатися розкриттям та розслідуванням злочинів. Проте, досьогодні бракує такої літератури, у тому числі з криміналістичного аналізу, що потребує якнайскорішого вжиття відповідних заходів щодо виправлення такого положення з метою забезпечення належних умов для ефективного розкриття та розслідування злочинів. 


\section{SECTION 8. THEORY AND HISTORY OF STATE AND LAW}

DOI 10.46299/ISG.2021.MONO.LEGAL.II-171-194

\subsection{Legal framework for the OSCE activities in ensuring the comprehensive security at the European level}

During the last decade, despite the considerable efforts of European peoples aimed at strengthening their own security, new challenges and threats have appeared which has led to a revival of discussion between neo-realists and neo-liberalists on the substance and content of national and international security. The ideas of those researchers who advocated the change of the paradigm bringing the security content from the predominantly military dimension to a new level, where its so-called soft nonmilitary aspects are determined as a priority, were popular until recently. It would seem that the massive changes that have taken place in the international system during the last decades of the last century, and, above all, the end of the confrontation of antagonistic socio-political systems, have opened up wide opportunities for ensuring international prosperity and directing joint efforts to counter threats of non-military character.

However, the events of the beginning of the $21^{\text {st }}$ century, connected with the increasing interference of separate states with the internal affairs of other states, expressed in the military operations of Russia in Georgia, the intensification of information and psychological pressure of the neighbouring state on our country in order to destabilize the socio-political situation, intensify the intelligence and subversive activity against Ukraine, military support for radicalized secessionist movements, acts of aggression in the East of Ukraine, annexation by the Russian Federation of the territory of the Autonomous Republic of Crimea, active military confrontation in Syria, etc., have shown the prematurity of the definitive waiver of the military aspects of international security.

At the same time, the problems of increasing the threats to regional security from international terrorism, extremism through the use of violence, organized crime, etc. remain relevant to the European community. The Charter for European Security 
adopted at the OSCE summit in Istanbul on November 19, 1999, emphasized that attention should be paid to threats to regional and global non-military security. It was acknowledged that terrorism in all its forms and manifestations, whatever it was called, is completely unacceptable. States parties undertook to increase their efforts in preventing the preparation and financing of acts of terrorism in their respective territories, as well as refusals to provide terrorists with asylum. It was emphasized that excessive and destabilizing accumulation and uncontrolled proliferation of small arms and light weapons poses a threat to peace and security. It was unanimously confirmed that it would be as secure as possible to protect itself from such new threats and challenges by strengthening the democratic institutions and the implementation of the rule of law principle.

The issue of the formation and development of a system of measures used by the OSCE to ensure international security, a comprehensive peace in Europe, therefore is seen as urgent and relevant. This is due not only to its absolute significance for the preservation of human civilization, but also to the high pragmatic values for the stable functioning of European states.

The aim of the article is to study the genesis of the organizational and legal mechanism of the OSCE's work in the field of security, determination of its role and place in the system of ensuring comprehensive peace in Europe.

The OSCE is based on the concept of comprehensive security, according to which no state should strengthen its security to the detriment of other states. The organization deals with security issues in terms of arms control, preventive diplomacy, confidencebuilding measures, human rights, the development of democratic institutions, election monitoring, economic and environmental security, and so on. All these dimensions are interconnected, interdependent and complementary.

Since its foundation, the Organization pays significant attention to the issue of ensuring general security. The confidence- and security-building measures, developed by the OSCE, support the cooperative approach of the Organization in this area. The legal basis in this area is a series of acts, in particular: Final Act of the Conference on Security and Cooperation in Europe (hereinafter - CSCE) (Helsinki Final Act, 1975) 
is the OSCE's fundamental document, which consolidated the need to reduce the risk of armed conflict, misunderstanding or misestimating of military activities that could cause for concern, especially in a situation where the State party does not have clear and up-to-date information on the nature of such activities. Such measures include information sharing, funding, verification, and various forms of military cooperation. They are aimed at reducing the risk of conflict, enhancing trust between OSCE participating States and promoting greater openness and transparency in defence planning and activities. They can also serve as an indicator of an early warning of potential conflicts.[219]

Treaty on Conventional Armed Forces in Europe (hereinafter - the CFE Treaty), November, 1990, imposed quantity restrictions on a number of categories of conventional (non-nuclear and non-missile) weapons, which the member states had the right to station in their territory or in its regions. The treaty made it possible to significantly reduce the offensive potentials of the former enemy states by ensuring effective control over the levels of conventional weapons. The area of application of the Treaty covers the whole land territory of the member states in Europe from the Atlantic Ocean to the Ural Mountains. For each state, the maximum levels for the presence of five categories of conventional weapons (battle tanks, armoured combat vehicles, pieces of artillery (large calibre artillery systems with a calibre of 100 millimetres and above), combat aircraft and attack helicopters) are defined.[220]

The 1992 Treaty on Open Skies seeks to promote confidence-building among States through improved mechanisms for monitoring military activities and compliance with existing armaments control treaties. The treaty establishes an open-air regime which purpose is to provide the opportunity for its participants to carry out flights of territories of each other.[221]

In accordance with the Lisbon Document of 1996, concerning the arms control, it is recognized that arms control, including disarmament and confidence-building and security, is an integral part of the comprehensive and coherent OSCE security concept.[222] 
The Astana Commemorative Declaration, adopted during the 2010 summit, calls for the reinstatement and modernization of the arms control and confidence- and security-building regimes and for breathing new life into them, and the expectation of a renewal of the Vienna Document.[223]

The key act of the confidence- and security-building measures is the Vienna Document 2011 on confidence-building measures and security provisions that provide for the annual exchange of military information on forces located in the territories of participating states, the provision of military messages for risk reduction, including advice on unusual military activities and dangerous incidents, preliminary reports on certain types of military activities, monitoring of certain types of military activities, mandatory demonstration of new samples of major weapons and military equipment coming into service of the armed forces of the States Parties exchange annual plans and compliance with them, including the implementation of inspection visits, the armed forces of the participating countries and evaluation of such visits.[224]

It should be noted that the Vienna Document, the CFE Treaty, the Treaty on the Open Skies are interconnected and mutually reinforcing with regard to arms control commitments. Together, they increase predictability, transparency and military stability and reduce the risk of a serious conflict in Europe. In addition, the CFE Treaty also provides for the limitation of major military equipment systems in Europe, which led to the process of disarmament in the 1990s.

Within the framework of the OSCE, along with further work on general security issues (holding negotiations on arms control, disarmament and confidence-building and security, reducing the risk of conflict, etc.), there was a certain reorientation on the prevention and settlement of local and regional conflicts. At the meeting of the Heads of State and Government of the CSCE participating States in Helsinki on July 9-10, 1992, a package of decisions was envisaged for the creation of crisis-oriented mechanisms of the CSCE, including peacekeeping operations. It was determined that in the context of crisis management the mechanism of peaceful settlement of disputes, the mission of special rapporteurs and the fact-finding mission come first.

The mechanism of peaceful settlement of disputes involves the use in the 
Organization of the means of peaceful settlement of international disputes, which should be understood as international legal methods and procedures for settling disputes between the conflicting parties in accordance with the principles of international law, without the use of coercion in any form. In accordance with the provisions of the Helsinki Document of 1992, the Committee of Senior Officials (CSO), in the event of a conflict, in order to establish the basis for its settlement, may send a mission of rapporteurs or a fact-finding mission, adopt or activate a mechanism of good offices, mediation or reconciliation, make a decision on the creation of a basis for negotiation.[225]

Generally, international disputes are settled through negotiations, which are the most affordable, flexible and effective means of peaceful settlement of disputes. This is due to the fact that the particular purpose, the composition of the participants, the level of representation in the negotiations, their organizational form and other procedural issues are agreed by the parties to the dispute. The positive outcome of the negotiations may be expressed either in the immediate resolution of the dispute, or in reaching an agreement on the use of another peaceful means of resolving it.

The use of good offices is carried out in response to the request of the parties to the dispute and on the initiative of the third party itself; they represent the actions of the non-participating party, aimed at establishing contacts between the parties involved in the dispute.

Provisions on the application of good offices and mediation are contained in the Hague Convention for the Pacific Settlement of International Disputes of 1907, according to which "Contracting States agree, In case of serious disagreement or conflict, before an appeal to arms the Signatory Powers agree to have recourse, as far as circumstances allow, to the good offices or mediation of one or more friendly Powers" (Article 2). The Convention states that "the part of the mediator consists in reconciling the opposing claims and appeasing the feelings of resentment which may have arisen between the States at variance" (Article 4).[226] The mediator's obligations cease from the time when one of the parties to the dispute or the intermediary himself verifies that the proposed means of reconciliation have not been 
adopted. Good offices and mediation are not mandatory.

Disputing parties may resort to consultations, which are a kind of negotiation. They are a relatively new means of peaceful resolution of international disputes, their appearance dates back to the $20^{\text {th }}$ century. The subject of consultations is usually issues that are of vital importance to States or international organizations. In order to conduct consultations, the parties may set up advisory committees, prescribe periodicity of meetings in advance, and so on. The mentioned peculiarities of consultations promote the search for compromise solutions by the conflicting parties, the continuity of the contacts between them, as well as the implementation of the agreements reached in order to prevent the emergence of new disputes and crises.

It should be noted that a number of international treaties provide for consultation as a peaceful means of resolving international disputes, for instance, according to Article 283 of the United Nations Convention on the Law of the Sea, 1982. The 1975 Vienna Convention on the Representation of States in their Relations with International Organizations of a Universal Character states that if there is a dispute between two or more States Parties to this Convention as to its application or interpretation, upon request any of them, consultations are held between them. At the request of any of the parties to the dispute to participate in the consultations, an Organization or a conference is invited.[227]

Other peaceful means should include mediation that involves the active direct involvement of a third party in a peaceful resolution of a dispute, including making suggestions on particular aspects of a matter or on a dispute as a whole. The task of the intermediary is to reconcile opposing claims and to eliminate tensions if it arises between disputing states. The OSCE devotes considerable attention to this form of dispute settlement in its activities. In particular, in order to facilitate the achievement of the objectives of the Assembly, in 2016, the mandate of the Special Representative on Mediation was established, according to which they should act as the main contact person in the Parliamentary Assembly for the mediation and conflict cycle; coordinate the Parliamentary Assembly's efforts and actions aimed at increasing readiness of the Parliamentary Assembly to mediate and promote dialogue; put forward concrete 
initiatives and measures as a continuation of the OSCE Parliamentary Assembly Resolution on the development of mediation capacity in the OSCE area, adopted in Baku in 2014; to monitor the development of the situation in the field of international security, paying particular attention to protracted and emerging conflicts; to maintain contact with the OSCE, its independent institutions and field operations on all issues relating to the conflict cycle; promote gender mainstreaming and gender analysis in mediation processes; to increase the contribution of parliamentarians to OSCE mediation activities, with a special emphasis on strengthening ties between the Parliamentary Assembly and the government's side of the organization; to liaise with other international mediation organizations, promoting the role of parliamentary diplomacy in preventing and resolving conflicts; to report to the President on all activities in a timely manner and to present a report to the Assembly and its Standing Committee as needed.[228]

The OSCE, while paying close attention to mediation in conflicts, focuses on enhancing the role of the OSCE mediators. To this end, the Ministerial Council, among other things, has been invited to focus on building capacity for systematic mediation support within the OSCE Conflict Prevention Centre (CPC), which includes, inter alia: 1) training and capacity building within the OSCE structures; 2) knowledge management and operational management; 3) establishing contacts, networking, cooperation and coordination with relevant local/national actors as well as with international, regional and sub-regional organizations; 4) providing prompt support to the Presidents, their special representatives, field operations managers and other relevant intermediaries from the OSCE (Article 10).[229]

The fact-finding missions and mission rapporteurs are established on the basis of decisions by the Committee of Senior Officials or the Advisory Committee of the Conflict Prevention Centre and have a clear mandate. States Parties are required to facilitate the mission of their territory in accordance with the mandate. As a result of the mission's work, reports are submitted to the discussions of the Committee of Senior Officials or the CPC Advisory Committee, as a rule, reports are made public.

An important means of resolving a dispute is the transfer of it to the judicial 
authorities, in particular arbitration. The obligation to recognize and enforce a decision is the key to distinguishing an arbitration procedure from the means of peaceful settlement of disputes set forth above. On the basis of the Convention on Conciliation and Arbitration of 1992 [230] (which came into force in 1994), the Court of Conciliation and Arbitration of the OSCE was established with the aim of settling by means of reconciliation and, where appropriate, the arbitration of disputes submitted to it for consideration by the States Parties Conventions that were not regulated within a reasonable time by negotiation. Disputes may include conflicts over territorial integrity, delimitation of maritime borders or environmental and economic issues. The court is not a permanent body and creates conciliation commissions and arbitration tribunals on a special basis.

Conciliation is carried out by the Conciliation Commission, which is created for each dispute. The Commission consists of intermediaries appointed by the States Parties (two persons) for a renewable period of six years. Intermediaries should be individuals who occupy or occupy high government or international positions and have recognized competence in the field of international law, international relations or dispute resolution.

Arbitration is carried out by the Arbitral Tribunal, which is created for each dispute. The Arbitral Tribunal consists of arbitrators and their deputies appointed by the States Parties (one from the state) for a term of six years, with the right of appointment for a repeated term. The judges and their deputies must have the qualifications required for appointment to the highest judicial positions in their countries or to be lawyers with recognized competence in the field of international law. Intermediaries, arbitrators and Registrar perform their functions in complete independence. World mediators and arbitrators form the entirety of the OSCE Court of Conciliation and Arbitration.

Within the organization, the OSCE High Commissioner on National Minorities, based on the Helsinki Document of 1992, has the mandate to provide early warning and, where necessary, to take urgent measures on issues of national minorities at the earliest possible stage, tense situations that have not yet emerged from the early 
warning stage, but potentially able, in the opinion of the High Commissioner, to escalate into a conflict in the OSCE area. The High Commissioner is authorized to: collect and receive from any source, including from the media and non-governmental organizations, information on the situation of national minorities and the role of the parties involved; to assess as early as possible the role of the parties directly concerned, the nature of the tensions of the situation and the recent events associated with it, as well as, where possible, potential consequences for peace and stability in the OSCE area; to visit any of the States parties and personally contact the directly concerned parties for the first-hand reception of information on the situation of national minorities and to apply preventive diplomacy.[231]

The main tools of the Organization for solving the problems of the early warning, conflict prevention and resolution, crisis and post-conflict recovery are a network of field operations and the Conflict Prevention Centre. The latter acts as a focal point for early warning, facilitates dialogue, supports mediation and other efforts to prevent and resolve conflicts, and supports the initiative of regional cooperation. The CPC is responsible for planning the creation, reorganization and closure of field operations. It plays a key role in supporting and coordinating the OSCE's activities in this field, analysing and providing policy advice, and acting as a bridge between field operations, the OSCE Secretariat and the leadership of the OSCE.

Field operations have individual mandates agreed upon by consensus of the participating States. Field operations are conducted solely with the consent of the host country. In addition to its headquarters, some field operations also have field offices, regional centres and/or training centres in their host countries.

The activities of the OSCE in the field are intended to assist host countries in fulfilling OSCE commitments in practice and to strengthen local capacity within specific projects that are tailored to their needs. These include support for law enforcement, minority rights, legislative reforms, rule of law and freedom of the media, promotion of tolerance and non-discrimination, etc. A number of on-field operations contribute to early warning and conflict prevention. In accordance with their mandates, 
some field operations are also tracking and reporting on field events, enabling them to cope with crises and play an important role in the post-conflict period.

Field operations establish and maintain a multitude of partnerships with local and national authorities, institutions and institutions, civil society, as well as with international organizations. Such partnerships support the coordination of efforts, ensure complementarity, and mutually reinforce their influence in the areas of joint participation.

OSCE field operations in the area of conflict prevention and resolution include: capacity building for local actors aimed at reducing potential causes and sources of conflict; facilitating the exchange of political and civil partners to eliminate the risk of conflict at an early stage; assisting in facilitating dialogue, mediation and trust in the activities of conflict-affected communities and communities; monitoring of the security situation in the OSCE participating States; promotion of confidence building; support for plans to respond to the national crisis.

OSCE field operations are active in the field of arms control. They work with national governments and international organizations. Their activities include: inventory control of small arms and light weapons and conventional ammunition, including destruction of them; support for national small arms control mechanisms; assistance in the rehabilitation of areas contaminated with explosives; Assistance in the disposal of hazardous chemicals stored in military facilities, including melange, highly toxic and flying component of rocket fuel; contributing to national initiatives on the collection of illicit small arms and light weapons; Supports initiatives to reduce illegal storage of weapons; carry out training and conduct awareness-raising campaigns.[232]

The organization has expanded a number of field operations that vary from one another to another, depending on their goals, in particular: the OSCE mission in Serbia was introduced in order to assist the state in the formation of strong, independent, accountable and effective democratic institutions. The mission interacts with government agencies, civil society and the media in the areas of rule of law and human rights, law enforcement, democratization, and media development. In addition, it interacts with other missions in the area and implements collaborative projects.[233] 
The main priority of the Mission in Moldova is to assist in resolving the Transdniestrian conflict. This controversial issue is rooted in the conflict that erupted in 1992 between the Transdniestrian authorities and the central government in Chisinau. Fierce clashes have led to several hundred victims: more than 100,000 have become refugees. The ceasefire agreement was reached in July 1992, and the parties undertook to negotiate a settlement of the conflict. Other activities of the Mission include arms control; human rights and the rule of law in Moldova; support for electoral processes, as well as the development of a free media environment.[234]

Since March 2014, the OSCE Special Monitoring Mission in Ukraine (hereinafter - OSCE SMM) has been introduced in connection with the appeal of the Government of Ukraine to the OSCE and a consensus decision of all 57 countries of the Organization. OSCE SMM is an unarmed civilian mission that operates 24/7 in all regions of Ukraine. Its main tasks are to observe and report on the situation in Ukraine impartially and objectively, and to promote dialogue between all parties to the conflict.[235] In addition, the Project Coordinator works in Ukraine, which helps the country to overcome the challenges of the crisis. Through his projects, he contributes to transformations that are crucial for a stable and democratic future of the country. The Coordinator is committed to a comprehensive multidimensional approach to projects covering a range of sectors, such as constitutional reform; reform of the law and criminal justice system; human rights education and legal education; use of the dialogue as a tool for managing crisis situations and implementing reforms; psychological and social rehabilitation of victims of the crisis of people; the fight against cybercrime and trafficking in human beings; mine detection and disposal programs and democratic control of the security sector; environmental protection; border security; freedom of the media; election; good governance and gender equality.[236]

In the event of an intensification of the conflict, a peacekeeping operation may be decided upon. In this case, the consent of the directly interested parties to conduct operations is required. Operations involve the sending of groups of military observers or peacekeeping forces. The individual membership of the OSCE peacekeeping 
operations is provided by individual participating States. Operations may be conducted in the event of conflicts between States Parties and in their territory. Their task is to monitor the ceasefire, monitor the withdrawal of troops, provide support in maintaining the rule of law and order, and provide humanitarian assistance. They do not foresee coercion and are carried out in a spirit of impartiality. The overall political control over the peacekeeping operation and its management is exercised by the Steering Board.

Requests for the start of the OSCE peacekeeping operations may be sent by one or more States Parties to the Committee of Senior Officials through the acting Chairperson. The decision to initiate peacekeeping operations and the direction of such missions shall be taken by consensus by the Council or acting as its agent by the Committee of Senior Officials. The Council/Committee of Senior Officials makes such decisions only when all interested parties demonstrate a commitment to create favourable conditions for the operation, in particular through the peace process, and willingness to cooperate. Before a decision is made to send a mission, the following conditions must be fulfilled: an effective and long-term cessation of fire is established; the necessary memoranda of understanding have been agreed upon by the parties concerned; and provided guarantees of permanent security of the personnel involved. Participating in OSCE peacekeeping operations is the right of all State Parties.[237]

The OSCE operations are conducted with due regard to the role of the United Nations. In the context of peacekeeping operations, the OSCE can use the resources and expertise of other organizations, such as the European Union, NATO, and the Commonwealth of Independent States. In each case, the OSCE decides to use the assistance of such organizations.

It should be emphasized that the OSCE peacekeeping operations cannot be considered as a substitute for negotiation and, therefore, should be considered as timelimited measures.

An essential component of the OSCE's comprehensive security is counteracting terrorism. With expertise in conflict prevention, crisis management and early warning, the OSCE contributes to global efforts to combat terrorism. It promotes a coordinated and coordinated approach to combating terrorism at all levels, including coordination 
between national authorities, cooperation among countries, cooperation with relevant international and regional organizations, etc. The strategic and priority areas of the OSCE's work on the fight against terrorism are: to promote the implementation of the international legal framework for combating terrorism and to intensify international legal cooperation in criminal matters related to terrorism; counteract violent extremism and radicalization; counteraction and termination of financing of terrorism; counteracting the use of the Internet for terrorist purposes; promoting dialogue and cooperation on counter-terrorism issues, in particular within the framework of publicprivate partnerships between public authorities and the private sector (business community, industry) as well as civil society and the media; strengthening national efforts to implement UN Security Council Resolution 1540 (2004) regarding the nonproliferation of weapons of mass destruction; enhancement of security of travel documents; the promotion and protection of human rights and fundamental freedoms.

The relevant activities are carried out by the OSCE executive bodies within their mandates, including the Secretariat, the OSCE Office for Democratic Institutions and Human Rights (Warsaw), the OSCE Representative on Freedom of the Media (Vienna) and the OSCE's field operations.[238]

In July 2017, the OSCE Parliamentary Assembly Standing Committee established the OSCE PA's Ad Hoc Committee on Countering Terrorism, which, in consultation with relevant partners, evaluates trends in the field of terrorism in the OSCE area in order to identify priority areas for cooperation in the OSCE PA in order to advance the efforts of the OSCE PA in countering terrorism. In accordance with the mandate, the Ad Hoc Committee is endowed with the following powers: to intensify the efforts of the OSCE PA in countering terrorism, with a special focus on inter-dimensional issues, to explore innovative approaches in the OSCE area and to report to the President and the Standing Committee; to review the trends of terrorism in the OSCE area and to develop promising policy recommendations aimed at enhancing the role of the OSCE and supporting the efforts of States parties to develop effective and relevant human rights counterterrorism response measures; promote inter-parliamentary dialogue and exchange of best practices and lessons learned on counter-terrorism issues; work in 
close contact with the OSCE executive bodies and relevant external counterparts in countering terrorism in order to enhance the visibility and effectiveness of the OSCE; to contribute to the implementation of the recommendations of the OSCE PA in the field of countering terrorism. As of 2019, the Ad Hoc Committee consists of 12 members covering North America and Europe.[239]

Border management is essential for security in the OSCE area. Borders are the first lines of defence of the country, and the movement of trade through them is crucial for the health of the economy all over the world. In 2005, the OSCE committed itself to achieve a balance between the need to maintain security against transboundary threats and the freedom of movement of people, goods, services and investments. Cooperation among States Parties is a key to this border management strategy and security, in particular with regard to international risks such as illicit drug trafficking, terrorism, migration, transport security and organized crime.

In connection with the development of security threats associated with new challenges that have intensified and sharply evolved in the $21^{\text {st }}$ century and are no longer limited to national borders. New criminal networks are usually interconnected and organized, and the borders between crime and terrorism are blurred. The OSCE responds to these transnational threats with a comprehensive strategy aimed at combating terrorism; border management and ensuring their safety; and building a modern, democratic and efficient police force.

In order to ensure better coordination, increase coherence and more efficient use of OSCE resources to address these challenges, the OSCE has created a Transnational Threats Department headed by a Co-ordinator. The Department consists of four subdivisions - Action against Terrorism, Border Security and Management, Strategic Police Matters, and Co-ordination Cell, and also deals with cross-cutting topics, such as cyber/ICT security and POLIS, OSCE's online law enforcement information system.

The OSCE operates to unite border authorities, international organizations and security partnerships. This included border monitoring operations in Georgia from 1999 to 2004; The Ohrid Border Process, which, between 2003 and 2007, created the 
basis for participating States to develop a coherent approach to border security and management in south-eastern Europe, as well as assessments and consultations on strategic planning in south-eastern Europe, Central Asia and the South Caucasus. Recently, much attention has been paid to Central Asia and Afghanistan.

The OSCE has launched an initiative to establish the OSCE Border Security and Management National Focal Point Network, allows for the regular exchange of information on specific frontiers. The OSCE supports this network by developing opportunities for the exchange of practice, information and ideas through annual meetings, multimedia conferences and events for small working groups.

Ensuring comprehensive security is an integral part of the functioning of OSCE bodies and institutions, in particular: the OSCE Forum for Security Cooperation ( hereinafter - the FSC), which is the decision-making body for military-political aspects of security, established as an integral part of the CSCE, the Helsinki Document of 1992 (Section V) [240], authorized to deal with a broad range of military-political issues, from traditional security between states and within states, to counteract transnational threats, such as arms trade, including weapons of mass destruction. Its main tasks are regular consultations and intensive cooperation on military security issues; negotiations on measures to strengthen confidence and security; further reducing the risks of conflict and implementing agreed measures. Decision No. 5/99 of October 6, 1999 [241], in connection with the establishment of the OSCE Communications Network, which is a computer system that provides a direct link between the capitals of the participating States for the transmission of communications concerning, inter alia, the provisions of the Vienna Document, the CFE Treaty and the Open Skies Treaty, the FSC is responsible for managing the network in accordance with the decision of the Rome meeting of the Council in December 1993 on the dissolution of the Advisory Committee of the Conflict Prevention Centre (CPC) and the transfer of its functions to the Standing Committee and the FSC, and taken at the Helsinki meeting in 1992 the FSC mandate to implement confidence- and security-building measures (CSBMs); if necessary, the FSC will inform other OSCE-related bodies on the work of the network, as well as consider their proposals for its wider use. 
The activities of the Forum: 1. Creating confidence through transparency and openness: The OSCE approach is that military security and stability can be achieved through increased military transparency and openness, as well as the exchange of military information. This is done through a series of mutually reinforcing and interconnected transactions and the exchange of relevant information. They provide verification of compliance with agreed commitments; notification of military actions; various forms of military cooperation and regular exchange of military information on defence planning documents; military budgets; defence policies and doctrines, including visits to military facilities, observation visits and demonstration of new weapon systems. These measures serve as indicators for early warning of potential conflict situations and help States avoid misunderstandings, contribute to stability and security. 2. Providing a platform for dialogue: The OSCE is a unique platform for mutual dialogue on security issues. Each state can raise security issues at any time, with the possibility of discussion among all 57 members every week. The Forum may propose solutions to these problems or develop measures to mitigate its impact on European security. 3. Fight against illicit small arms and ammunition: It is recognized that small arms and light weapons are the cause of most deaths in conflict and nonmilitary situations. The OSCE area includes many large manufacturers of such weapons, and the Organization is very serious about the problem of the illicit proliferation of weapons. States Parties have adopted a number of key documents for regulating the production, transfer, storage, collection and destruction of such weapons, as well as for controlling its exports. In particular, the Organization adopted the OSCE Document on Stockpiles of Conventional Ammunition (FSC.DOC/1/03 of 19 November 2003), the OSCE Action Plan on Small Arms and Light Weapons (Decision FSC.DEC/2/10 of 26 May 2010), Document/Decision on Small Arms and Light Weapons (FSC.DOC/1/00/ Rev.1 dated June 20, 2012); A number of practical guides on best practice regarding certain aspects of light control (Best Practice Guide on National Controls over Manufacture of Small Arms and Light Weapons; Best Practice Guide on Marking, Record-keeping and Traceability of Small Arms and Light Weapons; Best Practice Guide on National Procedures for Stockpile Management and 
Security; Best Practice Guide on National Control of Brokering Activities; Best Practice Guide on Export Control of Small Arms and Light Weapons; Best Practice Guide on the Definition and Indicators of a Surplus of Small Arms and Light Weapons; Best Practice Guide on National Procedures for the Destruction of Small Arms and Light Weapons; Best Practice Guide on Small Arms and Light Weapons in Disarmament, Demobilization \& Reintegration (DD\&R) Processes [242]). The OSCE helps States in implementing these documents. Upon request, it provides assistance in the collection and destruction of small arms and light weapons and conventional ammunition, helps to improve legislation for the effective control of small arms and helps to improve inventory management. It also facilitates the exchange of information on small arms and light weapons; the transfer of conventional weapons; and antipersonnel mines. 4. Non-proliferation of Weapons of Mass Destruction: The OSCE helps to implement UN Security Council Resolution 1540 on non-proliferation of weapons of mass destruction. He is implementing a project that assists interested States Parties in the development of national action plans and the establishment of the necessary legislative framework. The organization also conducts educational activities and provides specialized training, as well as helps to improve legislation, promote best practice and intensify cooperation with other international organizations. 5 . Democratic control of the armed and security forces: Recognizing the importance of democratic civilian control over the armed forces and security forces, the Forum adopted the OSCE Code of Conduct on Politico-Military Aspects of Security, 1994. This unique document represents a milestone in the management of the security sector, requiring States parties to exercise democratic control over their armed, internal, paramilitary, intelligence and police forces. The Code of Conduct also includes key principles of relations between States. States are required to ensure that their armed forces remain politically neutral and to guarantee the observance of human rights of security personnel. States report annually on national practices, helping to strengthen confidence and security in the OSCE area.

The OSCE Parliamentary Assembly is the forum for dialogue for 323 representatives from 57 Member States in order to achieve comprehensive security. 
Created by the Paris Summit in 1990 with a view to broadening OSCE participation in national parliaments in the participating States, also pursues other important objectives set out in the preamble of the Assembly's Rules of Procedure, in particular: assesses the fulfilment of OSCE objectives by the participating States; discusses issues raised at meetings of the Council of Ministers and summits of the OSCE Heads of State and Government; develops and facilitates the implementation of mechanisms for preventing and resolving conflicts; provides support for the consolidation and consolidation of democratic institutions in the OSCE participating States; promotes the development of OSCE institutional structures, as well as interaction and co-operation between existing OSCE institutions (Rule 2).[243] To achieve these goals, the Parliamentary Assembly uses various means, including the Final Declaration and a number of resolutions and recommendations that are adopted annually at the annual session. Other means include: the work of the committee with the solution of important contemporary international problems; various programs, including a large election observation program and various seminars for the development and consolidation of democracy; as well as sending special missions and Parliamentary Assembly delegations to problematic or crisis regions.

The Parliamentary Assembly consists of three General Committees, which correspond to the three main sections of the Helsinki Final Act: Committee on Political Affairs and Security; Committee on Economic Affairs, Science, Technology and Environment; Committee on Democracy, Human Rights and Humanitarian Questions. The first General Committee focuses on military-political aspects of security, the principles governing relations between States parties, and confidence-building measures in military matters. The Second General Committee examines the threats to economic and environmental security, as well as explores the possibilities for cooperation in these and related industries. The Third General Committee is considering humanitarian and human-rights threats to security.

The Acting Chairman is responsible, on behalf of the Council/Committee of Senior Officials, for coordinating and consulting on the ongoing activities of the Organization. When dealing with issues related to a crisis or conflict, the acting 
Chairman may at his own discretion appoint a personal representative with a clear and specific mandate to provide support. The intention to appoint a personal (special) representative and his mandate, the acting Chairman informs the Senior Officials Committee; he also includes in his reports to the Council/Committee of Senior Officials information on the activities of the personal representative, as well as any comments or recommendations submitted by the latter.

Given the wide range of issues that are part of a security policy and which require constant monitoring to address pressing issues (countering). the Personal Representative of the OSCE Chairperson-in-Office on Combating Racism, Xenophobia and Discrimination and Personal Representative of the OSCE Chairperson-in-Office on Combating Anti-Semitism has been mandated to raise awareness and report OSCE PA to preserve the issue of prejudice and discrimination in the OSCE area, including anti-Semitism, other religious and racial intolerance and other forms of intolerance; raise awareness and report to Parliamentary Assembly on the record of OSCE participating States in combating these problems; advise the Assembly on the implementation of a coherent policy on these issues, as well as the development of new policies and strategies, including how to protect affected people and communities; strive to promote dialogue and exchange of best practices within the Assembly to combat identified problems; as well as to communicate with relevant actors within the OSCE that are struggling with prejudices and discrimination in the OSCE area, including anti-Semitism, religious and racial intolerance, and other forms of intolerance.[244]

In 2010, the mandate of the Special Representative of the OSCE Chairperson-inOffice on Gender was established, according to which the Special Representative has the following tasks: to monitor the gender situation in the OSCE, including in the institutes and field missions, and report to the president; to promote the discussion of gender issues within the OSCE and, in particular, the OSCE Parliamentary Assembly; to develop, in cooperation with the Gender Group in the International Staff, a more active gender profile of the OSCE Parliamentary Assembly; to cooperate with the OSCE in organizing appropriate measures; to report on specific issues.[247] 
Trafficking in human beings affects all OSCE participating States and is both a security threat and a human rights problem. Almost all countries in the area are countries of origin, transit or destination or a combination of them. The OSCE deals with all relevant issues: human rights and the rule of law; corruption and the fight against crime; discrimination and inequality; economic, labour and migration policies. In 2003, the Office established the Office and the post of Special Representative and Co-ordinator for Combating Trafficking in Human Beings to assist States Parties in developing and implementing effective policies to counteract this negative phenomenon. The Special Representative (since 2004) collects information on trafficking in human beings in the OSCE area; promotes dialogue in the OSCE, in particular in its Parliamentary Assembly, on how to combat trafficking in human beings; advises the Assembly on the implementation of a coherent policy on these issues and on the development of a new policy; Think of how to protect victims and how to deal with criminal elements; maintains contact with relevant actors within the OSCE dealing with human trafficking issues.

The Special Representative and Co-ordinator urge Governments to include the fight against all forms of trafficking in their political agenda. For this purpose, they regularly visits the countries, holds meetings with state bodies, parliamentarians, representatives of judicial bodies and non-governmental organizations. After the visit, the Special Representative reports on what steps have been taken in the country, as well as what challenges the country faces and in which areas it is possible to strengthen the anti-trafficking policy. These reports contain specific and targeted recommendations to help the country meet its commitments to combat trafficking in human beings, and are subject to promulgation. In 2016, the Office of the Special Representative visited the OSCE participating States - Armenia, the Czech Republic, Turkey and the United States of America. The next visit was to Romania. In 2017, the Office of the Special Representative visited the OSCE participating States - Denmark, Mongolia and the Russian Federation. The next visit was made to Canada.[246]

The OSCE cooperates with field operations, the Office of the OSCE Special Representative and Co-ordinator for Combating Trafficking in Human Beings and 
international partner organizations, providing specialized training and expert advice to law enforcement and non-governmental organizations, whose cooperation is crucial in combating human trafficking. The victim-focused approach focuses on children who are sexually abusive online.

The OSCE is promoting security policy outside the Organization, and in 2017, the objective of facilitating cooperation in this area was to establish the mandate of the Special Representative on Mediterranean Affairs, whose task is to strengthen the Mediterranean dimension of the Assembly's work, given that European security is directly related to security and stability in the Mediterranean region; to maintain contacts with Mediterranean partners on cooperation and to engage in activities in support of relations between the Mediterranean area and the OSCE area; to encourage meetings and exchanges with the OSCE Contact Group with Mediterranean Partnership, to participate in the OSCE Annual Conference on behalf of the Assembly, and to make special visits, where possible, to the Mediterranean Partnership; to consider ways to strengthen the role of the Assembly's Mediterranean Forum; to consider tools for promoting the organization of the Mediterranean Forum under the auspices of the OSCE Parliamentary Assembly; to report regularly on the events in the region, including opportunities for improving cooperation.[247]

2018 was marked by the establishment of the mandate of the Special Representative on Central Asia, who is responsible for promoting the active participation of parliamentarians from Central Asia (Kazakhstan, Kyrgyzstan, Tajikistan, Turkmenistan and Uzbekistan) in the work of the OSCE Parliamentary Assembly on strengthening parliamentary system in the area; maintaining communication and work of the OSCE field presence in the region, as well as relevant OSCE institutions, international and regional organizations and diplomatic missions; encouraging closer contacts between parliaments in the region to facilitate the expansion of intra-regional cooperation in all three dimensions of the OSCE; providing reports to the President of the Assembly on developments in the area, including the possibility of expanding the parliamentary dialogue and further inter-parliamentary cooperation between the states of Central Asia.[248] 
In 2018, the Special Representative on South East Europe was appointed to serve the following areas: to promote dialogue in all strata of society, in particular at the parliamentary level, in order to promote reconciliation and reconstruction in SouthEastern Europe, and in particular in the Western Balkans, and contribute to the transformation and strengthening of democratic institutions; maintain close contact and serve as a focal point for the Assembly in the area as a whole and its participation in the activities of the Council for Regional Cooperation, in particular; to advise and report to the President on the situation in the area, in particular on the development of the situation in Bosnia and Herzegovina and on the Belgrade-Pristina dialogue, as well as the issue of the issue of the former Yugoslav Republic of Macedonia; to communicate with relevant actors within the OSCE, as well as with PA Committees dealing with migration and terrorism dealing with issues related to the area.[249]

It should be noted that the OSCE responds to changes in world politics, political life of countries, challenges and threats to the world law and order, to this end, efforts are being made to reform the existing legal, institutional framework for cooperation between Member States in this area. The organization has developed a number of guidelines for the management and reform of the security sector (Security Sector Governance and Reform: Guidelines for OSCE Staff), which provide the OSCE executive bodies and their staff with an instrument for implementing a coherent and coordinated approach to maintaining governance and reform processes in the state-led security sector.[250] Initiated by Switzerland in 2014 (CIO.GAL/18/14), the concept of governance and security sector reform is a relatively new concept, which is closely linked to a comprehensive understanding of the concept of security in terms of the OSCE. Thus, through its own institutions and field missions, the OSCE has for a long time served as a source of expertise for many participating countries on a number of important aspects of the Guidelines for OSCE Staff, including police reform, border management and security, the fight against terrorism, the fight against corruption, the reform of the justice sector etc. The concept of the Guidelines already has a broad legal framework within the OSCE. In recent years, the concept of the Guidelines has been increasingly recognized by the OSCE participating States and the executive bodies of 
this Organization as a concept that plays an important role in conflict prevention, early warning, crisis management, and peace building.

Practical activities in the area of security sector reform and cooperation include reform of the law, reduction and/or transformation of armies, training of personnel of the rights of military personnel, as well as humanitarian law. These activities are carried out in conjunction with OSCE field operations, the Office for Democratic Institutions and Human Rights and the Conflict Prevention Centre. They all work closely with governments, non-governmental organizations and civil society.

Some of the main OSCE topics in this area include: rules of interaction and integrity in the defence and security bodies; protection of human rights of servicemen; strengthening the supervisory role of parliament; promoting better communication of the institutions of the security sector with citizens; promotion of active participation of civil society; retraining of dismissed personnel for civil work; provision of social rights in the transition from conscript to professional army; consideration of the bill.

Since its foundation, the OSCE has taken a prominent place in the system of international intergovernmental organizations, identifying a major priority for itself in the field of comprehensive security. The presence of representatives of the Organization on the territory of the states where the crisis has arisen due to armed conflicts, unstable political conditions, etc. inspires the belief in the population of the state for the better, urges the authority to make maximum efforts to eliminate existing problems. The presence of representatives of the OSCE, in particular the OSCE Special Monitoring Mission in Ukraine and the Project Co-ordinator, is very significant, considering the situation in the East of Ukraine, which has a protracted nature, since 2014.

In order to enhance the OSCE's operational component in the field of security, there is an urgent need to increase the level of its monitoring structures, which should work closely with the media and bring the results of their work to the attention of the public so that the public can react to these reports and feel real support and express their opinion on how to improve its work. Of particular importance is the rapid response to events that have their consequences related to the humanitarian nature of 
providing real help to victims of humanitarian catastrophes, military conflicts, political crises, which entail mass riots, human rights violations, etc. This case involves mechanism for additional protection of the civilian population during the crisis, when there is a political crisis in the state, undemocratic processes that are not explicitly expressed or suppressed by the state authorities. 


\section{2 Юридична клінічна освіта як засіб формування нової методології навчання}

Сучасна підготовка кваліфікованих правників вимагає введення в роботу професорсько-викладацького складу нових, нетрадиційних форм і методів викладання. Одним із інноваційних методів є участь у роботі юридичної клініки.

У науково-дослідній літературі переважають такі характеристики поняття «юридична клініка»:

по-перше, вона $є$ видом юридичного навчання, за якого студенти набувають практичних навичок під керівництвом викладачів через надання юридичних послуг населенню;

по-друге, вона є особливою частиною вищої юридичної освіти, що дозволяє свідомо та цілеспрямовано формувати у студентів навички професійної діяльності на основі організації такої форми навчання як керована викладачем практика надання правової допомоги малозабезпеченим особам;

по-третє, вона $є$ навчанням під час проходження практики, організованим на базі навчального закладу, у ході якого науковий, навчальний та практичний напрямки реалізуються у процесі спільної діяльності викладачів і студентів, створюючи при цьому новий вид взаємовідносин між ними, вважає Голова Правління всеукраїнської громадської організації «Асоціація юридичних клінік України» В.А. Слова.

Наведені дефініції характеризують поняття «юридична клініка»у якості соціально-орієнтованої навчальної діяльності у галузі права, яка є складовою частиною навчального процесу у вищому навчальному закладі, інноваційною (інтерактивною) методикою вироблення у студентів практичних навичок.

Найбільшим розповсюдженим розумінням юридичної клініки $\epsilon$ інституційне. У 2003-2005 pp. Асоціацією юридичних клінік України було сформовано власну внутрішню правову базу, спрямовану на забезпечення та уніфікацію діяльності юридичних клінік та їх відмежування від інших форм об'єднань студентів та молодих юристів, які надають юридичну допомогу 
населенню (прийнято Стандарти юридичних клінік України, Типове положення про юридичну клініку та Етичний кодекс діяльності юридичної клініки в Україні). Згідно з положеннями цих Стандартів, юридичні клініки могли діяти у двох організаційно-правових формах:

1) як структурний підрозділ вищого навчального закладу чи факультету, який їм підпорядковується;

2) як формування при вищому навчальному закладі чи факультеті, яке взаємодіє з ними на підставі договору та може бути юридичною особою.

Нормативно, мета діяльності юридичної клініки закріплена у Положенні про юридичну клініку «Істина» ДДУВС від 27.04.2017 № 295, під якою розуміється закріплення студентами (курсантами)- консультантами теоретичних знань та набуття ними практичних умінь і навичок професії юриста, формування в них поваги до принципів права, підвищення рівня правової культури населення, а також надання безоплатної правової допомоги особам, які іï потребують.

У монографічній літературі пропонують розрізняти три основні функції юридичної клінічної діяльності, а саме:

1) правозахисну (правової допомоги населенню);

2) просвітню (правової освіти населення);

3) навчально-формуючу (полягає у набутті студентами перших навичок практичної діяльності у сфері права, формуванні особистої громадянської позиції, моральності, соціальної відповідальності).

Вважаємо, найбільш значимою третю функцію, оскільки юридичні клініки при вищих навчальних закладах створюються перш за все для навчання студентів, а інші функції реалізуються як похідні.

Відповідно, основна мета існування юридичної клініки - освітня - набуття студентами практичних навичок у процесі надання безоплатної правничої допомоги населенню, у той час як інші напрями їхньої діяльності є вторинними (похідними). 
Саме поняття «юридична клінічна освіта» не має статусу юридичної дефініції. Перша спроба нормативно-правового закріплення поняття «юридична клінічна освіта» здійснена Міністерством освіти і науки України спільно із Міністерством юстиції України. Вони передбачали в проекті Концепції розвитку юридичної освіти поєднання навчання здобувачів вищої юридичної освіти 3 діяльністю у юридичних клініках, для чого правничі школи мають сприяти їхньому розвитку у вигляді окремих структурних підрозділів закладів вищої освіти та впровадженню в освітній процес навчальних курсів 3 правничої клінічної практики.

Найчастіше поняттям «юридична клінічна освіта» оперують у наукових дослідженнях, 3 метою характеристики унікального методу підготовки майбутніх фахівців за напрямом «Право» (з обов’язковим використанням юридичних клінік в навчальному процесі, як бази для отримання студентами додаткових теоретичних знань і практичних навичок 3 надання безоплатної правничої допомоги населенню). Зокрема, Ю.М. Савелова зазначає, що юридична клінічна освіта - це метод (методика) викладання, яка використовується в юридичних вищих навчальних закладах, у рамках якого студенти представляють інтереси реальних клієнтів (відвідувачів) під керівництвом викладачів та практикуючих юристів.

Призначення цього інтерактивного методу навчання студентів-юристів правових навичок полягає у посиленні їх практичної підготовки шляхом залучення до практичної юридичної діяльності та надання безоплатної правової допомоги малозабезпеченим верствам населення.

На противагу іншим методам підготовки правників, перевагами юридичної клінічної освіти є: отримання практичних навичок студентами до початку реальної практичної діяльності; поєднання теоретичних знань одночасно 3 отриманням практичних навичок.

Як зазначають В.С. Журавський та О.Л. Копиленко, робота молодих юристів у юридичній клініці дозволяє усвідомити цінність і значення отриманих 
теоретичних знань та оволодіти методологією та процесуальною технікою застосування цих знань на практиці.

Зміст відповідного методу підготовки майбутніх юристів полягає у створенні у самій структурі навчального закладу вищої освіти окремого навчально-практичного підрозділу, основною метою діяльності якого є набуття студентами практичних умінь і навичок з надання правничої допомоги особам 3 числа незаможних верств населення.

Організація і діяльність таких інституцій має подвійну мету: з одного боку - надання правничої допомоги людині, яка іï потребує, а з іншого - набуття студентами, які виявили бажання працювати в такій структурі на волонтерських засадах, реального первинного досвіду:

у спілкуванні з людиною, яка звернулась по допомогу;

в аналізі конкретних життєвих ситуацій і правових відносин, в які щоденно вступає людина, на підставі законодавчих та нормативно-правових актів;

консультування клієнтів; підготовки правових висновків, процесуальних документів та рекомендацій;

в окремих випадках - навіть, представництво інтересів особи перед іншими особами, органами державної влади, та місцевого самоврядування.

Юридична клініка може забезпечити безперервність практики студентів у майбутній професії. Адже специфіка роботи юридичної клініки полягає в постійному (протягом навчального року) залученні студентів до вирішення реальних справ клієнтів, які звертаються за юридичною допомогою 3 використанням усіх правових способів реалізації та захисту прав. Більшість юридичних клінік в Україні практикують не лише підготовку юридичних роз'яснень, а й складання процесуальних документів, представництво інтересів клієнтів, що становить класичну систему професійних умінь і навичок юристапрактика. Спеціалізовані юридичні клініки, крім названих видів діяльності, практикують правопросвітні заходи, тим самим надаючи своїм учасникам навички публічного виступу, користування педагогічними технологіями. 
Як засіб формування нової методології навчання, юридична клінічна освіта дозволяє впровадити в систему освіти такі принципи:

демократичний стиль відносин між викладачем і студентом (на противагу авторитарному стилю, характерному для традиційної системи освіти в цілому);

педагогіку співробітництва (студент стає рівноправним учасником освітнього процесу);

індивідуальний підхід до студента;

захист прав людини як визначальна складова професійної діяльності правника;

компоненту опанування практичних навичок, що органічно доповнює отримані у вищому навчальному закладі теоретичні знання.

Основна причина недостатнього використання юридичної клініки, як основної платформи набуття практичних навичок студентами, пов'язане 3 нормативною неврегульованістю такої можливості. Подолати дану прогалину, хоча б частково, допоможе прийняття проекту Концепції розвитку юридичної освіти від 28 лютого 2020 року, у якій передбачено сприяння розвитку юридичних клінік у вигляді окремих структурних підрозділів закладів вищої освіти та впровадження в освітній процес навчальних курсів 3 юридичної клінічної практики, а одним з індикаторів досягнення є збільшення відсотка залучення здобувачів освіти до участі в юридичних клініках, кількості активно функціонуючих юридичних клінік.

3 метою легалізації поняття «юридична клінічна освіта» та набуття останнім офіційного статусу - юридичної дефініції, вважаємо за необхідне:

1. Прийняти у цілому проект «Концепції розвитку юридичної освіти», розроблений Міністерством освіти і науки України спільно із Міністерством юстиції України.

2. Встановити у нормативно-правових актах 3 організації навчального процесу, проведення навчальної практики та обліку часу роботи науковопедагогічних працівників приписи щодо необхідності безпосереднього упровадження положень про діяльність юридичних клінік; 
3. Закріпити на рівні зобов'язуючої норми права приписи щодо необхідності функціонування юридичної клініки, як умови акредитації юридичного закладу вищої освіти та отримання ним ліцензії на підготовку юристів;

4. Нормативно передбачити систему громадського контролю за якістю функціонування юридичних клінік у структурі юридичного закладу вищої освіти. 


\section{REFERENCES}

1. Антонова C.Є., Мартинюк Г.Ф. Інформаційна безпека. Державне управління: удосконалення та розвиток. 2019. № 11. - URL: http://www.dy.nayka.com.ua/?op=1\&z=1528

2. URL: https://zakon.rada.gov.ua/laws/show/537-16\#Text

3. Сопілко I.M. Становлення інформаційного суспільства та інформаційні загрози в мережі Інтернет. Юридичний вісник. Повітряне і космічне право. 2017. № 3. С. 61-69.

4. Інтернет-3МІ в Україні: проблеми визначення нормативно-правового статусу та врегулювання діяльності. Національний інститут стратегічних досліджень. - URL: http://old2.niss.gov.ua/articles/1085/

5. Голуб О. Сайти соцмереж як джерело інформації. 24.02.2016. - URL: https://ms.detector.media/sotsmerezhi/post/16123/2016-02-24-saiti-sotsmerezh-yakdzherelo-informatsii/

6. Сафаров А. Інтернет-ЗМІ і відповідальність за достовірність інформації. Інститут масової інформації. 11.01.2019. - URL: https://imi.org.ua/articles/internetzmi-i-vidpovidal-nist-za-dostovirnist-informatsii-i64

7. Як зареєструвати онлайн-ЗМІ. Центр демократії та верховенства права. 25.01.2019. - URL: https://cedem.org.ua/consultations/yak-zareyestruvaty-onlajn$\mathrm{zmi} /$

8. Почепцов Г.Г. Информационные войны. М., Рефл-бук; К., Ваклер, 2000. $576 \mathrm{c}$.

9. Мітенко О.В. Інформаційна безпека як складова національної безпеки України. Інформаційна безпека людини, суспільства, держави. 2019. № 1. С. 2736.

10. Белый А. Кто хочет, чтобы Украину считали, самой криминальной страной Европы или немного о фейковых рейтингах. - URL: https://golos.ua/i/763261

11. Игнатченко И.Г. Доктринальные основы становления и развития культурно-управленческого цикла в Украине. Журнал научных публикаций аспирантов и докторантов. Курск, 2014. № 7 (97). С.47-53.

12. Хатнюк Ю.А. Полномочия субъектов публичного управления в сфере культуры. Свропейські перспективи. Київ, 2016. № 1. С.50-56.

13. Деякі питання діяльності Міністерства культури та інформаційної політики: Постанова Кабінету Міністрів України від 16.10.2019 р. № 885. URL: https://zakon.rada.gov.ua/laws/show/885-2019-п\#Text (дата звернення 01.06.2021). 
14. Про оптимізацію системи центральних органів виконавчої влади: Постанова Кабінету Міністрів України від 14.09.2010 p. № 442. URL: https://zakon.rada.gov.ua/laws/show/442-2014-п\#Text (дата звернення 01.06.2021).

15. Про Український культурний фонд: Закон України від 23.03.2017 р. № 1976-VIII. URL: https://zakon.rada.gov.ua/laws/show/1976-19\#Text. (дата звернення 01.06.2021).

16. Про центральні органи виконавчої влади: Закон України від 17.03.2011 p. № 3166-VI. URL: https://zakon.rada.gov.ua/laws/show/1976-19\#Text. (дата звернення 01.06.2021).

17. Ігнатченко І.Г. Особливості реалізації державної політики України у сфері культури: сучасний стан та світові стандарти. Теорія i практика правознавства. 2013. Вип.1. URL: http://nbuv.gov.ua/UJRN/tipp_2013_1_16 .

18. Don Adams \& Arlene Goldbard. (2003). Community, Culture and Globalization. GIA Reader. Vol. 14. № 3 (Fall 2003). P. 7-29.

19. H. H. Chartrand, C. McCaughey The Arm's Length Principle and the Arts (1989). An International Search for Models of Support ; M. C. Cummings Jr\&J. M. D. Schuster (eds). - N.-Y. : American Council for Arts, 1989. P. 43-80.

20. Про внесення змін до Бюджетного кодексу України щодо створення Державного фонду підтримки медицини, спорту, освіти, культури та науки: Проект Закону України від 16.02.2021 № 5073. URL: https://zakon.rada.gov.ua/laws/show/1082-20\#Tехt (дата звернення 01.06.2021).

21. Про державний бюджет України на 2021 рік: Закон України від 15.12.2020 p. № 1082-IX. URL: https://zakon.rada.gov.ua/laws/show/1082-20\#Text (дата звернення 01.06.2021).

22. О. Ткаченко. У бюджеті-2021 на культуру виділили на 52\% більше, ніж минулого року. Суспільне медіа. 17.12. 2000 p. URL: https://suspilne.media/88875u-budzeti-2021-na-kulturu-vidilili-na-52-bilse-niz-minulogo-roku-tkacenko/

23. Торгівля людьми як соціальна проблема в Україні: Інформаційнометодичний посібник, підготовлений Управлінням державної реєстрації нормативно-правових актів, правової роботи та правової освіти Головного територіального управління юстиції у Житомирській області, 30.05.2019. 19 с. URL: http://www.solor.gov.ua/docs/all/mediaua.pdf (дата звернення 01.03.2021).

24. Про ратифікацію Конвенції Організації Об'єднаних Націй проти транснаціональної організованої злочинності та протоколів, що ії доповнюють (Протоколу про попередження і припинення торгівлі людьми, особливо жінками i дітьми, і покарання за неї і Протоколу проти незаконного ввозу мігрантів по суші, морю і повітрю: Закон України від 04.02.2004 № 1433-IV. Дата оновлення: 04.02.2004. URL: https://zakon.rada.gov.ua/laws/show/1433-15\#Text (дата звернення 08.03.2021). 
25. Про протидію торгівлі людьми: Закон України від 20.09.2011 № 3739VI. Дата оновлення: 01.01.2020. URL: https://zakon.rada.gov.ua/laws/show/373917\#Техt (дата звернення 30.02.2021).

26. Висвітлення в засобах масової інформації проблеми торгівлі людьми: навчальний посібник. Київ, 2007. 161 c. URL: https://www.osce.org/files/f/documents/e/3/36904.pdf (дата звернення 02.03.2021).

27. Азаров М.Ю. Торгівля людьми з метою вилучення органів. Боротьба 3 торгівлею людьми: тези доповідей учасників Міжнародної науково-практичної конференції (21 червня 2013 р., Львів), 2013. С. 9-12.

28. Кримінальний кодекс України: Кодекс України від 05.04.2001 № 2341III. Дата оновлення: 13.08.2020. URL: https://zakon.rada.gov.ua/laws/show/234114/conv\#top (дата звернення 28.02.2021).

29. Luts V.V. Terms in civil legal relations. Правоведение. 1989. №1. Р.37-43.

30. Butnev V.V. The concept of the mechanism of protection of subjective civil rights. Mechanism of protection of subjective civil rights. Collection of scientific works. Yaroslavl: Yaroslavl. SU, 1990. P. 5-17.

31. Krasheninnikov E.A. The right to claim. Problems of improving the legislation on the protection of subjective civil rights. Yaroslavl: YarSU, 1988. P. 515 .

32. Civil law: a textbook / Ed . A.P. Sergeev and Yu.K. Tolstoy. Moscow: ТЕИС, 1996. Ch.1. 300 p.

33. Ioffe O.S. Soviet civil law. Moscow: Юридическая литература, 1967. 494 p.

34. Russian civil law. Course of lectures. Part 1 / Braginsky M.I., Zalessky V.V., Klein N.I., Litovkin V.N., etc .; Edited by: Sadikov O.N. Moscow: Юридическая литература, 1996.304 p.

35. Civil law: in 2 volumes / Ed. E.A. Sukhanov. 2nd ed. reworked. and add. Moscow: БЕК, 1998. V.1. 819 p.

36. Rappoport Ya.I. Limitation periods in obligations for rail freight. Харків. 1959. $75 \mathrm{p}$.

37. Ioffe O.S. Soviet civil law (lecture course). The general part. Property rights. General doctrine of obligations. - Leningrad: ЛГУ, 1958.512 p.

38. Civil Code of the Republic of Belarus. URL: http://www.pravo.by/world_of_law/text.asp?RN=hk9800218

39. Civil Code of the Republic of Moldova. URL: http://online.zakon.kz/Document/?doc_id=1006061\&doc_id2=1006061\#sub_id=100 0022991 2\&sub id $2=1770000 \&$ sel link $=1000022991 \_2$ 
40. Gribanov V.P. Exercise and protection of civil rights. Moscow: Статут, 2000. $411 \mathrm{p}$.

41. Dobrovolsky A.A. Claim form of protection of rights. The main questions of the doctrine of the claim. Moscow: МГУ, 1965. 190 p.

42. Tsikalo V.I. Prescription in civil legal relations. Author's ref. dis ..... cand .. jurid. science. Lviv, 2004. 19 p.

43. Cosack K. Lehrbuch des deutschen burgerlichen Rechts auf der Grundlage des Bürgerlichen Gesetzbuchs für das Deutsche Reich. 5 Auft Jena, 1898 - XXVI, - Bd. 1. $615 \mathrm{~S}$.

44. Masevich M.G. Limitation period. Хозяйство и право. 1993. №9. Р. 133144.

45. Dobrovolsky A.A. Legal regulation of legal protection by the Fundamentals of civil procedure and Civil procedure Codes of the Union Republics // Problems of application of the Fundamentals of Civil Legislation and the Fundamentals of Civil Procedure of the USSR and the Union Republics. Saratov: СГУ, 1971. P. 133-137.

46. Krasheninnikov E.A. The concept and subject of the statute of limitations. Yaroslavl. 1997. 86 p.

47. Buryak O.V. General characteristics of the concept of "statute of limitations" and its role in resolving legal disputes. Вісник господарського судочинства. 2005. № 2. P. 79-85.

48. Motovilovker E.Ya. The right to protection of the claim as a subject of the statute of limitations. Problems of protection of subjective civil rights. Collection of scientific works. Yaroslavl: Yaroslavl Publishing House. University, 1998. P. 22-33.

49. Rozhnov O.V. Some issues of regulation of terms in civil proceedings. Прооблеми законності. 2004. № 67. Р. 55 -61.

50. Lebedeva K.Yu. Statute of limitations in the system of civil law terms: dis.... cand .. jurid. Sciences. Tomsk, 2003. 243 p.

51. Vilnyansky S.I. Lectures on Soviet civil law. Kharkov: KSU, 1958. Part 1. $339 \mathrm{p}$.

52. Borovikovsky A. Judge's report. Prescription. Sankt-Peterburg, 1892, V. 2. $260 \mathrm{p}$.

53. Oertmann P. Burgerliches Gesetzburch. Allgemeiner Teil / Berlin, 1898. 599 S.

54. Luts V.V. Terms in civil law. Abstracts of lectures on a special course. Lviv: LSU, 1992. 108 p.

55. Guyvan P.D. Some issues of timeliness of application of security and legal operational measures. Право та управління. 2011. №1. P.95 - 102. 
56. Guyvan P.D. Action in the time of normative acts. Юридическая практика. 2005. № 22. P. 12-13.

57. Guyvan P.D. Statute of limitations: monograph. Kharkiv: Pravo, 2012. 448 p.

58. Popov B.V. Statute of limitations. Text and commentary to Art. 44-51 of the Civil Code of the RSFSR. Moscow: Право и жизнь, 1926. 32 p.

59. Vakhoneva T. Some issues of action and application of statute of limitations in Ukraine. Підприємництво, господарство і право. 2005. №2. P.80-83.

60. Kozhukhar A.N. The right to judicial protection in legal proceedings / ed. E.G. Martinchick. Chisinau: Штиница, 1989. 140 p.

61. Erdelevsky A.M. Compensation for moral damage and statute of limitations. Закон. 1997. №12. Р. 102-103.

62. Engelman I.E. About the statute of limitations on Russian civil law. Historical and dogmatic research. Moscow: Статут, 2003. 511 p.

63. Gauch P., Schluep W., Schmid J., Rey H. Schweizerisches Obligationenrecht. General part. 7 Aufl. Zurich, 1998. Bd. 2. 623 p.

64. Gordienko G. Procedural aspects of the application of the statute of limitations by courts of general jurisdiction. Підприємництво, господарство і право. 2005. № 12. P. 50-52.

65. Cherepakhin B.B. Statute of limitations in the new Soviet civil law // Current issues of Soviet civil law / Under. Ed. S.N. Bratus, O.S. Ioffe, J.A. Marten. Moscow: Юридическая литература, 1964. Issue. 36. P.71-93.

66. Abramov S.N. Statute of limitations. The second rework. edition. Moscow: Из-во Мин. юстиции СССР.1946. 24 р.

67. Vyshnovetska S.V. Terms of protection of labor rights. Theoretical and practical problems of the rule of law in Ukraine: materials of reports and abstracts of speeches of sciences. conferences of teachers, graduate students and law students. faculty of Chernivtsi state. un-ty under Yu. Fedkovych, May 4-5, 1995. Chernivtsi: Chernivtsi University, 1995. Issue. 2. P. 45-58.

68. Кримінальний кодекс України від 05.04.2001 р. // Офіційний сайт Верховної Ради України/Законодавство. - [Електронний режим доступу]. https://zakon.rada.gov.ua/laws/show/2341-14\#Text

69. Закон України «Про судоустрій та статус суддів» від 02.06.2016 р. // Офіційний сайт Верховної Ради України/Законодавство. - [Електронний режим доступу]. - https://zakon.rada.gov.ua/laws/show/1402-19\#Text

70. Постанова Великої Палати Верховного Суду від 18.04.2018 р. у справі №569/1111/16-к //Сдиний державний реєстр судових рішень. - [Електронний режим доступу]. - https://reyestr.court.gov.ua/Review/73532589 
71. Кримінальне право України. Загальна частина: Підручник для студентів юридичних вузів і факультетів / Г.В. Андрусів, П.П. Андрушко, В.О. Беньківський та ін.; За ред. П.С. Матишевського та ін. - К.: Юрінком Інтер, 1997. $-512 \mathrm{c}$.

72. Кримінальний кодекс України від 28.12.1960 р. // Офіційний сайт Верховної Ради України/Законодавство. - [Електронний режим доступу]. https://zakon.rada.gov.ua/laws/show/2001-05\#Text

73. Науково-практичний коментар до Кримінального кодексу України. - 4е вид., переробл. та доповн. Відп. ред. С.С. Яценко. - Київ: А.С.К., 2005. - 848 с.

74. Постанова Пленуму Верховного Суду України від 6.11.2009 р. №10 «Про судову практику у справах про злочини проти власності» // Офіційний вебсайт Верховної Ради України / Законодавство. - [Електронний режим доступу] https://zakon.rada.gov.ua/laws/show/v0010700-09\#Text

75. Кримінальне право (Особлива частина): підручник / За ред. О.О. Дудорова, Є.О. Письменського. Т.1 - Луганськ: видавництво «Еталон-2», 2012. -780 c.

76. Постанова Верховного Суду України від 15.11.2012 р. у справі №5$15 \kappa \mathrm{c} 12$ // Сдиний державний реєстр судових рішень // https://reyestr.court.gov.ua/Review/28332568

77. Академічний тлумачний словник української мови: в 11 томах // $\mathrm{AH}$ УРСР, Інститут мовознавства; за ред. І.К. Білодіда. - Том 8. - К: Наукова думка, $1977,-$ C.243

78. Наказ Центрального управління Служби безпеки України №383 від 23.12.2020 p. // Офіційний сайт Верховної Ради України / Законодавство України. - [Електронний режим доступу]: https://zakon.rada.gov.ua/laws/show/z005221\#Text

79. Закон України «Про Національну поліцію» від 2.07.2015р.// Офіційний сайт Верховної Ради України / Законодавство України. - [Електронний режим доступу]: https://zakon.rada.gov.ua/laws/show/580-19\#Text

80. Кримінальний процесуальний кодекс України від 13.04.2012 р. // Офіційний сайт Верховної Ради України / Законодавство України. [Електронний режим доступу]: https://zakon.rada.gov.ua/laws/show/4651-17\#Text

81. Кримінальний кодекс Федеративної Республіки Німеччина від 15.05.1871 р. в редакції Акту Парламенту від 13.11.1998 р. // Сайт бюро ОБСЄ 3 демократичних інститутів та прав людини // https://www.legislationline.org/download/id/6115/file/Germany_CC_am2013_en.pdf

82. Кримінальному кодексі Франції від 22.07.1992 p. // Сайт бюро ОБСЄ з демократичних інститутів та прав Людини 
https://www.legislationline.org/download/id/3316/file/France_Criminal\%20Code\%2 0updated\%20on\%2012-10-2005.pdf

83. Theft Act $1968 / /$ Website managed by The National Archives on behalf of HM Government //

https://www.legislation.gov.uk/ukpga/1968/60/crossheading/definition-of-theft

84. New York State Law / Penal Law // http://ypdcrime.com/penal.law/article140.htm

85. Конститція України // Інформаційний сервер Верховної Ради України. Електронний ресурс. Режим доступу: https://zakon.rada.gov.ua/laws/show/254к/96-вр\#Text

86. Грищук В.К. Философско-правовая парадигма ответственности человека : моногр. Хмельн.: Хмельн. ун-т управл. и права. 2015. 640 с.

87. В’юник М.В., Карчевський М.В., Арланов О.Д. Кримінально-правове регулювання в Україні: реалії та перспективи (аналітичні матеріали) / упор.: Ю.В. Баулін. Харків: Право, 2020. 212 с.

88. Баулин Ю.В. Обстоятельства, исключающие преступность деяния : моногр. В наук. вид. : Баулін Ю. В. Вибрані праці. Х.: Право, 2013. 928 с.

89. Селіванов В. Поняття і категорії в процесі історичного розвитку юридичної науки // Вісник Академії правових наук України. 2005. № 4. С. 3-15.

90. Малько А.В. Правовые стимулы и правовые ограничения как парные юридические категории // Правоведение. 1995. № 1. С. 3-13.

91. Нырков В.В. Поощрения и наказания как средства реализации правовой политики // Правовая политика и правовая жизнь. 2001. № 3. С. 193-202.

92. Васильев А.М. Диалектическая связь категорий общей теории права // Советское государство и право. 1974. № 1. С. 18-23.

93. Баулін Ю.В. Звільнення від кримінальної відповідальності: моногр. В наук. вид. : Баулін Ю. В. Вибрані праці. Х.: Право, 2013. 928 с.

94. Малько А.В. Стимулы и ограничения в праве (теоретикоинформационный аспект): дисс. докт. юрид. наук: спец. 12.00.01 Теория и история государства и права; история политических и правовых учений. Саратов. Саратов. гос. акад. права. 1995. 362 с.

95. Нырков В.В. Поощрение и наказание как парные юридические категории: дисс. канд. юрид. наук: спец. 12.00.01 Теория и история государства и права; история правовых учений. Саратов. Саратов. гос. акад. права. 2003. 222 c. 
96. Давньогрецька філософія першого (досократівського) етапу : Інформаційний сайт Освіта України. Електронний ресурс. Режим доступу: https:/osvita.ua/vnz/reports/philosophy/13299/

97. Гегель Г.В.Ф. Наука логики. М.: Мысль, Том 2. 1971. 248 с.

98. Энгельс Ф. Происхождение семьи, частной собственности и государства. К. Маркс и Ф. Энгельс : Сочинения. Изд. 2-е. Том 21. М.: Гос. издво полит. лит-ры, 1961. С. 23-178.

99. Тацій В.Я. Об'єкт і предмет злочину в кримінальному праві України: моногр. Харків: Право, 2016. 256 с.

100. Звечаровский И.Э. Стимулирование в праве: понятие и структурные элементы // Правоведение. - 1993. - № 5. - С. 112-117.

101. Баранов В.М. Поощрительные нормы советского социалистического права : моногр. Саратов: Изд-во Сарат. ун-та, 1978. 148 с.

102. Трахтеров В.С. О задачах наказания по советскому уголовному праву // Учен. зап. Харьк. юрид. ин-та. 1955. Вып. 6. С. 3-11.

103. Про практику призначення судами кримінального покарання: постанова Пленуму Верховного Суду України від 24 жовтня 2003 р. № 7 // Інформаційний сервер Верховної Ради України. Електронний ресурс. Режим доступу: https://zakon.rada.gov.ua/laws/show/v0007700-03\#Text

104. Про судову практику у справах про необхідну оборону : постанова Пленуму Верховного Суду України від 26 квітня 2002 р. № 1 // Інформаційний сервер Верховної Ради України. Електронний ресурс. Режим доступу: https://zakon.rada.gov.ua/laws/show/v0001700-02\#Text

105. Голіна В.В. Судимість і суспільство: стаття. В наук. вид. : Вибрані праці. Харків.: Право, 2020. 592 с.

106. Гегель Г.В.Ф. Философия права. М.: Мысль, 1990. 524 с.

107. Велике вчення Конфуція // Інформаційний сайт Освіта України. Електронний ресурс. Режим доступу: https://osvita.ua/vnz/reports/politolog/16770

108. Закон України «Про судову експертизу» від 25.02.1994 URL: http://zakon.rada.gov.ua/laws/show/4038-12.

109. Кримінальний процесуальний кодекс України URL: https://zakon.rada.gov.ua/laws/show/4651-17.

110. Про затвердження Інструкції про призначення та проведення судових експертиз та експертних досліджень та Науково-методичних рекомендацій $з$ питань підготовки та призначення судових експертиз та експертних досліджень затверджено наказом Міністерством юстиції України від 08.10.1998 №53/5, зареєстровано в Міністерстві юстиції України 03.11.1998 за №705/3145. 
111. Національний стандарт №1 «Загальні засади оцінки майна і майнових прав»,затверджено постановою Кабінету Міністрів України від 10 вересня 2003 p. №1440.

112. Петрова I. А., Снігерьов О. П. Сутність та перспективи розвитку судово-товарознавчих експертиз, Право та безпека, 2011. №3(40). C156-159.

113. Александров Ю.В. Кримінальне право України: Загальна частина: підручник [Ю.В. Александров, В.І. Антипов, М.В. Володько та ін.]. Київ: Юридична думка, 2002. 408 с.

114. Бажанов М.І., Баулін Ю.В.та ін.. Кримінальне право України. Загальна частина: підручник для студ. юрид. спец. вищ. закл. освіти. Київ: Атіка, 2001. 436 c.

115. Бараненко Б.І. До застосування поняття «організовані злочинні групи як безпосередні об'єкти оперативно-розшукового втручання (деякі проблемні питання). Теорія оперативно-розшукової діяльності правоохоронних органів; заг. ред. В.Л. Регульського. Львів: ЛІВС при НАВС України. 2000. С. 15-29.

116. Бірюков Г.М. Стратегічні й тактичні основи протидії наркобізнесу в Україні. Міжнародне співробітництво у сфері протидії незаконному обігу наркотичних засобів і психотропних речовин: матер. міжнар. наук.-практ. конф. Д.: Дніпроп. держ. ун-т внутр. справ, 2007. С. 16-21

117. Боротьба з тероризмом. Навч. посіб. за заг ред.. проф. В.В. Коваленка. Джужа О.М. Никифорчук, Комарницький В.М. та ін. Київ: Видавниций дім «Скіф». 2013. 584 c.

118. Ганова Г.О. Відповідальність співучасників умисного вбивства у кримінальному законодавстві Великобританії, США, Франції і Німеччини.205 Держава і право: збірник наукових праць. Юридичні і політичні науки. К.: Ін-т держави і права ім. В.М. Корецького НАН України, 2009. № 43. С. 581-585.

119. Герасименко А.П., Дамов Ю.В. Классификация преступных груп. Совершенствование оперативно-розыскной деятельности в современных условиях. Омск: Омская ВШ милиции МВД СССР, 1990. С. 34-46.

120. Експрес-аналіз про стан злочинності, пов'язаної з наркотиками в Україні, за 2013р. Київ: ДБНОН МВС України, 2016. 120 с.

121. Ивасенко В.Б. Незаконный оборот наркотиков и криминальный рынок. Проблемы борьбы с криминальным рынком, экономической и организованной преступностью. Москва: МВД РФ, 2001. С. 30-35

122. Конвенція ООН проти транснаціональної організованої злочинності 2000 року : прийнята резолюцією 55/25 ГА ООН від 15 лист. 2000 р. Збірник міжнародних договорів України про правову допомогу у кримінальних справах. Багатосторонні договори. К.: Алерта, 2006. С. 554-606. 
123. Кримінологія: підручник для студ.вищ.навч. закл. О.М. Джужа, Я.Ю. Кондратьєв, О.Г. Кулик, П.П. Михайленко та ін.; за заг. ред. О.М. Джужи. К.: Юрінком Інтер, 2002. 416 c.

124. Литвиненко B.I., Бірюков Г.М., Сервецький I.В. Оперативно-тактичне забезпечення розкриття злочинів, вчинених організованими групами: монографія, за заг. ред. Я.Ю. Кондратьєва. К.: НАВС України, 2003.150 с

125. Литвиненко B.I., Сервецький І.В. Правові та організаційно-тактичні основи боротьби з організованою злочинністю в Україні: монографія під заг. ред. член-кор. Акад. пед. наук України Я.Ю. Кондратьєва. К. : РВВ МВС України, 2003. $248 \mathrm{c}$.

126. Міжнародна поліцейська енциклопедія: у 10 т. відп. ред.: В.В. Коваленко, Є.М. Моісєєв, В.Я. Тацій, Ю.С. Шемшученко. - Т. VI. Оперативнорозшукова діяльність поліції (міліції). - Київ: Атіка, 2009. - 1128 с.

127. Науково-практичний коментар Кримінального кодексу України. 4-те вид., перероб. та доповн. За ред. М.І. Мельника М.І. Хавронюка. Київ: Юридична думка, 2007. $1184 \mathrm{c.}$

128. Недільський В.В. Оперативно-розшукове забезпечення пошуку наркотичних засобів. Автореферат дисертації на здобуття наукового ступеня кандидата юридичних наук. Спеціальність - 12.00.09. кримінальний процес та криміналістика; судова експертиза; оперативно-розшукова діяльність. Київ. HABC, $2012.18 \mathrm{c}$.

129. Незаконний обіг наркотиків в Україні: стан та тенденції (аналітичний огляд: 2018-2019 рр.).Київ: РНБО,2020.45 с.

130. Профілактика злочинів: Підручник. О.М. Джужа, В.В. Василевич, О.Ф. Гіда та ін..: За заг. ред. док. Юрид. наук, проф.. О.М. Джужа. К.: Атіка, 2011. 720 c.

131. Толкаченко О.О. Тактика виявлення злочинних груп : автореф. дис. на здобуття наук. ступеня канд. юрид. наук: спец.: спец. 12.00 .09 «Кримінальний процес і криміналістика; судова експертиза; оперативно-розшукова діяльність». Одеса: ОДУВС, 2011.20 с.

132. Чаплинський К.О. Організована злочинна група: поняття та ознаки за українським законодавством. Право і суспільство. 2006. № 3.С. 34-38.

133. Lyubchenko M.I. Yuridichna termInologIya: ponyattya, osoblivostI, vidi: monografIya. HarkIv: TOV «VIDAVNITsTVO PRAVA LYuDINI», 2015. $280 \mathrm{~s}$.

134. Pro zatverdzhennya Poryadku zdIysnennya ofItsIynogo perekladu bagatostoronnIh mIzhnarodnih dogovorIv UkraYini na ukraYinsku movu: Postanova KabInetu MInIstrIv UkraYini vId 17 bereznya 2006 r. \# 353. URL: https://zakon.rada.gov.ua/laws/show/353-2006-p\#Text (data zvernennya: 09.01.2021). 
135. Korotkiy slovnik perekladatskih termInIv. AKZhILAN. Byuro perekladIv: ofItsIyniy veb-sayt.URL: http://www.lingvist.dp.ua/ua/dictionary.html (data zvernennya: 09.01.2021).

136. Shumilo M., SnItsa T. OsoblivostI perekladu yuridichnih tekstIv. FIlologIchniy diskurs. Vipusk 4, 2016. S. 266-272.

137. KulIchenko A.K. Etapi latinskih zapozichen $\mathrm{v}$ anglIyskIy movI. TeoretichnI ta metodologIchnI doslIdzhennya movi. FIlologIchnI nauki/3. DNI, 2009. URL: http://www.rusnauka.com/8_DNI_2009/Philologia/35934.doc.htm (data zvernennya: 25.12.2020).

138. Antonov AD Teoriticheskie osnovy kriminalizatsii [Theoretical foundations of criminalization] Antonov. - Access mode:http://www.kpress.ru/bh/2002/2/rantonov/rantonov.asp

139. Kolakovsky L. On collective identity / Leszek Kolakowski // My correct views on everything: [trans. S. Yakovenko]. - Kyiv-Mohyla Academy House, 2005. P. 103.

140. Kozellek Reingart. Time layers. Research in the theory of history / Reinhart Kozellek; [trans. with him. Vladimir Shved]. - K .: SPIRIT AND LETTER, 2006. - P. 317.

141. Mikhailovsky I.V. On religious and moral foundations of law / I.V. Mikhailovsky. Mikhailovsky // Russian philosophy. - SPb .: Aleteyya, 1999 - P. 307.

142. Trubetskoy E.N. Law and morality / E.N. Trubetskoy // Russian philosophy of law / authors-comp. A.P. Albov, D.V. Maslennikov, M.V. Salnikov. - St. Petersburg University of the Ministry of Internal Affairs of Russia. - SPb .: Aleteyya, 1999. - P. 219.

143. Sheregi F.E. Sociology of law. Applied research / F.E. Sheregi. - SPb .: Aleteyya, 2002. - P. 21.

144. Антонович В. Три національні типи народні [Електронний ресурс] / В. Антонович. - Режим доступу: http://litopys.org.ua/anton/ant03.htm

145. Габермас Ю. Громадянство і національна ідентичність / Ю. Габермас // Націоналізм : [антологія / упоряд. О. Проценко, В. Лісовий ; літ.ред. Л. Білик]. - [2-ге вид. перероб. і доп.] - К. : Смолоскип, 2000. - С. 343-359.

146. Гедікова Н. П. Ідейні та політико-правові засади лібералізму: світовий досвід та українська практика (політологічний аспект) : монографія / Н. П. Гедікова ; Одеський національний ун-т ім. І.І.Мечникова. - О. : Оптімум, 2009. $330 \mathrm{c}$.

147. Гирич I. Знакова стаття Омеляна Пріцака [Електронний ресурс] / I. Гирич. - Режим доступу: http://www.i-hyrych.name/Hrushevsky/ Pricak.html\#Anchor21 
148. Донченко О. Архетипи соціального життя і політики : (глибинні регулятиви психополіт. повсякдення) / О. Донченко. - Київ : Либідь, 2001. - 334 c.

149. Дорошенко Д. Розвиток науки українознавства у XIX - на початку XX ст. та її досягнення [Електронний ресурс] / Д. Дорошенко // Українська культура : лекції за редакцією Д. Антоновича. - К., 1993. - 592 с. - (Пам'ятки історичної думки України) - Режим доступу: http://litopys.org.ua/

150. Козловски П. Общество и государство: неизбежный дуализм / П. Козловски. - М.: Республика, 1998. - 368 с.

151. Кривда Н.Ю. Ікона як один із чинників формування української етнічної ідентичності / Н. Кривда // Вісник Черкаського університету. Серія Філософія. - Черкаси, БІЦ Черкаського національного університету імені Б. Хмельницького, 2017. - № 1. - С. 3-11

152. Крип'якевич I. Історія України / І. Крип’якевич. - Львів: Світ, 1990. $520 \mathrm{c}$.

153. Лисий I. Куліш [Електронний ресурс] / І. Лисий // Філософська думка в Україні: Біобібліографічний словник. - К., 2002. - Режим доступу: http://litopys.org.ua/fdm/fdm32.htm

154. Лисяк-Рудницький І. Каразин і початки українського національного відродження / І. Лисяк-Рудницький // Лисяк-Рудницький І. Історичні есе : в 2 т / [пер. $з$ англ. М. Базік, У. Гавришків, Я. Грицака та ін.]. - Т.1. - К.: Основи, 1994. - C. 203-220.

155. Лисяк-Рудницький I. Україна між Заходом і Сходом / I. ЛисякРудницький // Лисяк-Рудницький І. Історичні есе : в 2 т / [пер. 3 англ. М. Базік, У. Гавришків, Я. Грицака та ін.]. - Т.1. - К.: Основи, 1994. - С. 1-9.

156. Лисяк-Рудницький I. Українці в Галичині під Австрійським пануванням / I. Лисяк-Рудницький // Лисяк-Рудницький I. Історичні есе : в 2 т / [пер. $з$ англ. М. Базік, У. Гавришків, Я. Грицака та ін.]. - Т.1. - К.: Основи, 1994. - C. 413-450.

157. Огієнко I. Українська церква: Нариси 3 історії Української Православної Церкви: У 2 т.: Т. 1 / І. Огієнко (архієпископ Холмський i Підляський). - Прага, Вид.-во Ю. Тищенка, 1942. - 236 с.

158. Пламенац Дж. Два типи націоналізму / Дж. Пламенац // Націоналізм : [антологія / упоряд. О. Проценко, В. Лісовий ; літ.ред. Л. Білик]. - [2-ге вид. перероб. і доп.] - К. : Смолоскип, 2000. - С. 483-494

159. Руссо Ж.-Ж. Об Общественном договоре, или Принципы политического Права [Электронный ресурс] / Ж. Ж. Руссо. - Режим доступа: http://lib.ru/FILOSOF/RUSSO/prawo.txt 
160. Салтовський О.І. Концепції української державності в історії вітчизняної політичної думки (від витоків до початку XX сторіччя). - К.: Вид. ПАРАПАН, 2002. - 396c.

161. Семчишин М. Тисяча років української культури : іст. огляд культур. процесу / Мирослав Семчишин. - Нью-Йорк [та ін. : б. в.], 1985. - 550 с. (Бібліотека українознавства ; т. 52).

162. Список «Книги буття українського народу» M.I. Костомарова, що був вилучений у М.І.Гулака під час обшуку в Олексіївському Равелліні 2 квітня 1847 p. [Електронний ресурс] / M. Костомаров. - Режим доступу: $\mathrm{http} / / /$ litopys.org.ua/rizne/kmt02.htm

163. Чижевський Д. Нариси з історії філософії на Україні. - К., 1992 Режим доступу: http://litopys.org.ua/chyph/chyph03.htm

164. Вільчик Т. Б. Адвокатура як інститут реалізації права на правову допомогу: порівняльно-правовий аналіз законодавства країн Європейського Союзу та України: дис. ... д-ра юрид. наук. Харків, 2016. 490 с. Теорія і практика правознавства.

165. Святоцька В. О. Інститут адвокатури України: становлення та розвиток: автореф. дис. ... канд. юрид. наук. Львів, 2010. 16 с.

166. Тацій Л. В. Юридична природа адвокатури в системі захисту прав $\mathrm{i}$ свобод людини і громадянина: автореф. дис. ... канд. юрид. наук. Харків, 2008. $20 \mathrm{c}$.

167. Курс цивільного процесу: підручник. В. В. Комаров, В. А. Бігун, В. В. Баранкова та ін.; за ред. В. В. Комарова. Харків: Право. 2011. 1352 с.

168. Цивільне судочинство України: основні засади та інститути: монографія. В.В. Комаров, К.В. Гусаров, Н.Ю. Сакара та ін.; за ред. В.В. Комарова. Харків: Право, 2016. 848 с.

169. Про внесення змін до Закону України «Про адвокатуру та адвокатську діяльність» (щодо статусу і гарантій адвокатської діяльності та формування органів адвокатського самоврядування): проект Закону України № 1794 від 19.01.2015 p. URL: http://w1.c1.rada.gov.ua/pls/zweb2/webproc4_1?pf3511=53631.

170. Про внесення змін до Закону України «Про адвокатуру та адвокатську діяльність» та деяких інших законодавчих актів України (щодо статусу і гарантій адвокатської діяльності та формування і роботи органів адвокатського самоврядування): проект Закону № 1794-1 від 04.02.2015 p. URL: http://w1.c1.rada.gov.ua/pls/zweb2/webproc4_1?pf3511=53817.

171. Про внесення змін до статті 10 Закону України «Про судоустрій і статус суддів» щодо малозначних спорів у судах: проект Закону № 5221 від 04.10.2016 p. URL: http://w1.c1.rada.gov.ua/pls/zweb2/webproc4_1?pf3511=60174. 
172. Про Стратегію реформування судоустрою, судочинства та суміжних правових інститутів на 2015-2020 роки: Указ Президента України від 20.05.2015 p. № 276/2015. URL: http://zakon2.rada.gov.ua/laws/show/276/2015.

173. Святоцька В. О. Адвокатура України у світлі євроінтеграційних прагнень. Право України. 2015. № 10. С. 105-112.

174. Святоцька В. О. Наближення стандартів організації та діяльності адвокатури України до загальноєвропейських. Актуальні проблеми судового права: матеріали міжнар. наук.-прак. конф., присвяч. пам'яті проф. I. С. Марочкіна (Харків, 30 жовт. 2015 р.); Нац. юрид. ун-т ім. Я. Мудрого, каф. орг. суд. та прав. органів. Харків : Право, 2015. С. 96-97.

175. Резолюція (78) 8 Комітету міністрів про юридичну допомогу та консультації: Міжнар. док. № (78) 8 від 02.03 .1978 p. URL: http://zakon5.rada.gov.ua/laws/show/994_132.

176. Бычкова С. С., Чурпита А. В. Адвокат как участник гражданских процессуальных правоотношений. Цивилистическая процессуальная мысль: междунар. сб. науч. ст. / редкол.: В. В. Комаров и др. Киев: Алерта, 2015. Вып. 4: Адвокатура. С. 22-30.

177. Кодекс поведінки європейських адвокатів: прийнятий на пленар. сесії Ради адвокат. об'єднань та спілок адвокатів Європи 28 жовт. 1988 р., 3 поправками від 28 листоп. 1988 р., 6 груд. 2002 р., 19 трав. 2006 р. / [пер. 3 англ.]; Національна асоціація адвокатів України. URL: http://unba.org.ua/assets/uploads/legislations/inshidokumenty/kodeks_povedinky _yevropeyskykh_advokativ(ukr).pdf.

178. Общие принципы для сообщества юристов: приняты в Международной ассоциацией юристов (IBA) 20.09.2006 г. в г. Чикаго. URL: http://advokpalata21.ru/ urbanleft/osnovyepruristov.html.

179. Основні положення про роль адвокатів: Міжнар. док. від 01.08.1990 p. URL: http://zakon3.rada.gov.ua/laws/show/995_835.

180. Основні принципи, що стосуються ролі юристів: Міжнар. док. від 07.09.1990 p. URL: http://zakon5.rada.gov.ua/laws/show/995_313.

181. Загальний кодекс правил для адвокатів країн Європейського Співтовариства: Міжнар. док. від 01.10.1988 p. URL: http://zakon3.rada.gov.ua/laws/show/994_343.

182. Про внесення змін до Конституції України (щодо правосуддя): Закон України від 02.06.2016 p. № 1401-VIII. URL: http://zakon5.rada.gov.ua/laws/show/1401-19.

183. Про судоустрій і статус суддів: Закон України від 02.06.2016 р. № 1402-VIII. URL: http://zakon3.rada.gov.ua/laws/show/1402-19. 
184. Kemp L. Framework for the future? Exploring the possibility of majority voting in the climate negotiations // International Environmental Agreements: Politics, Law and Economics. Springer. 2015; Bichler M., Kersten G., Strecker S. Towards a structured design of Electronic Negotiations // Group Decision and Negotiation. July. 2003. Vol. 12, iss. 4. P. 311-335.

185. Goodpaster C. Lawsuits as negotiations // Negotiation j. 1992. July. P. 221.

186. Основы альтернативного разрешения споров / А. Г. Авдей, В. И. Самарин, О. В. Мороз и др. - Минск: Белорус. гос-ный ун-т, 2016. - 224 с.

187. Bove M. La conciliazione nel sistema dei mezzi di resoluzione delle controversie civili [Risorsa elettronica]. - $\quad$ URL: http://people.unica.it/carlopilia/files/2013/12/Bove.pdf

188. Donald G. Gifford, A Context - Based Theory of Strategy Selection in Legal Negotiation, - American journal of criminial law. - Vol. 26. - 1998. - 515 P.

189. Melvin Aron Eisenberg. Private Ordering Through Negotiation: DisputeSettlement and Rulemaking. - Harvard Law Review Vol. 89, No. 4 (Feb., 1976), pp. 637-681

190. Gary Bellow, Bea Moulton. The Lawyering Process: Negotiation. Foundation Press, 1981. - 297 P.

191. Roger Fisher, William Ury, Bruce Patton. Getting to Yes: Negotiating Agreement Without Giving in. - Random House., 2012. - 240 P.

192. Howard Raiffa. Science of Negotiation. - Belknap Press: An Imprint of Harvard University Press; Revised ed. edition (March 15, 1985). - 384 P.

193. Gerald R. Williams. Legal Negotiation and Settlement. - West Publishing Company. - 1982. - 207 P.

194. Carrie Menkel-Meadow. The role of trial in promoting cooperative negotiation. - Symposium: Dispute Resolution in Criminal Law. - Marquette University School of Law, 2007. - 424 P.

195. Gary T . Lowenthal,. A General Theory of Negotiation Process, Strategy and Behavior. - University of Kansas Law Review. - 1982. - pp. 69 - 114

196. Donald G. Gifford, A Context - Based Theory of Strategy Selection in Legal Negotiation, - American journal of criminial law. - Vol. 26. - 1998. - 515 P.

197. Mnookin \& Kornhauser, Bargaining in the Shadow of the Law: The Case of Divorce, 88 Yale L.J. - 1979.- pp. 950-977.

198. Herbert M. Kritzer. Let's Make a Deal: Understanding the Negotiation Process in Ordinary Litigation. - Madison, WI : University of Wisconsin Press, 1991. - pp. 136-137. 
199. Marc Galanter. World of Deals: Using Negotiation to Teach About Legal Process, 34 J. Legal Educ. - 1984. - pp. 268-269.

200. Конституція України. URL: http://zakon1.rada.gov.ua/cgibin/laws/main.cgi?nreg=254\%EA\%2F96-\%E2\%F0. (дата звернення 28.04. 2021)

201. Кримінальний кодекс України від 5 квітня 2001 р. № 2341-III URL: http://zakon1.rada.gov.ua/cgi-bin/laws/main.cgi?nreg=2341-14 (дата звернення 28. 04. 2021)

202. Кримінальний Процесуальний Кодекс України від 13.04.2012 р. № 4651-VI URL: http://zakon5.rada.gov.ua/laws/show/4651-17 (дата звернення 28. 04. 2021)

203. Про прокуратуру: Закон України від 14.10.2014 р. № 1697-VII URL: https://zakon.rada.gov.ua/laws/show/1697-18\#Text (дата звернення 28. 04. 2021)

204. Про Регламент Верховної Ради України: Закон України від 10.02.2010 p. № 1861-VI URL: https://zakon.rada.gov.ua/laws/show/1861-17\#Text (дата звернення 28. 04. 2021)

205. Про Вищу раду правосуддя: Закон України від 21.12.2016 р. № 1798VIII URL: https://zakon.rada.gov.ua/laws/card/1798-19 (дата звернення 28. 04. 2021)

206. Положення про порядок роботи Кваліфікаційно-дисциплінарної комісії прокурорів від 27. 04.2017 p. URL: https://zakon.rada.gov.ua/laws/show/n0003900-17\#Text (дата звернення 28. 04. 2021)

207. Положення про Раду прокурорів України від 27. 04. 2017 p. URL: https://zakon.rada.gov.ua/laws/show/n0002900-17\#Text (дата звернення 28. 04. 2021)

208. Регламент Вищої ради правосуддя від 24. 01.2017 р. № 52/0/15-17 URL: http://www.vru.gov.ua/legislative_acts/28 (дата звернення 28. 04. 2021)

209. Безкровний Є. А. Правовий статус прокурора. Ірпінський юридичний часопис: науковий журнал. 2019. Вип. 2. С. 78 - 84

210. Добровольський Д. М. Незалежність як засада організації та діяльності органів прокуратури: дис. канд. юрид. наук. Одеса, 2016. 195 с.

211. Карпова Н. Ю. Злочини проти правосуддя, які пов’язані з обмеженням права особи на захист: дис. канд. юрид. наук. Київ, 2018. 369 с

212. Свириденко С. В. Досудове розслідування у кримінальному провадженні щодо осіб, які користуються недоторканністю: дис. канд. юрид. наук. Київ, 2018. 232 с.

213. Юхно О. О. Особливості досудового розслідування щодо окремої категорії осіб: науково-методичні рекомендації. ХНУВС, 2017. 60 с. 
214. Хлус А.М. Криминалистический анализ и направления его применения при расследовании преступлений / А.М. Хлус // Проблемы применения уголовного и уголовно-процессуального законодательства : сборник материалов международной научно-практической конференции / Коллектив авторов; под ред. В.М. Зимина; Т.Ю. Новиковой, Е.А. Ануфриевой, В.П. Бодаевского, Д.А. Захарова. - Симферополь : ИТ «АРИАЛ», 2018. С. 341-344.

215. Чорноус Ю. М. Криміналістичне забезпечення розслідування злочинів : монографія / Ю. М. Чорноус. - Вінниця : ТОВ «Нілан-ЛТД», 2017. 492 c.

216. Настольная книга следователя. Расследование преступлений против личности (убийство, торговля людьми) : научно-методическое пособие: / под ред. А. И. Дворкина, А. Б. Соловьева. - М.: Издательство «Экзамен», 2007. 589 с.

217. Криминалистика: учебное пособие /А. В. Дулов [и др.]; под ред. А. В. Дулова. - Минск: ИП «Экоперспектива», 1998. 415 с.

218. Степанов С. Д. Применение современных информационных технологий для анализа полноты следственных действий в расследовании преступлений // Криминалистика - прошлое, настоящее, будущее: достижения и перспективы развития : материалы Международной научно-практической конференции, приуроченной к 60-летию образования службы криминалистики (Москва, 16 октября 2014 года). - М., 2014. С. 266-270.

219. Conference on Security and Co-operation in Europe, Final Act, available at $<$ https://www.osce.org/helsinki-final-act?download=true $>$

220. Treaty on Conventional Armed Forces in Europe, 19 November 1990, available at $<$ https://www.osce.org/library/14087?download=true $>$

221. Treaty on Open Skies, 24 March 1992, available at $<$ https://www.osce.org/library/14127?download=true>

222. Lisbon Document, 3 December, available at $<$ https://www.osce.org $/ \mathrm{mc} / 39539$ ?download=true $>$

223. Astana Commemorative Declaration: Towards a Security Community, 1 December 2010, available at $<$ https://www.osce.org/mc/74985?download=true $>$

224. Vienna Document 2011: Negotiations on Confidence- and SecurityBuilding Measures, 22 December 2011, available at $<$ https://www.osce.org/fsc/86597?download=true $>$

225. Helsinki Document: The Challenges of Change, Conference for Security and Co-operation in Europe, 9-10 July 1992, available at $<$ https://www.osce.org/mc/39530?download=true>

226. Convention for the Pacific Settlement of International Disputes, 1907, available at $<\mathrm{http}$ ///egal.un.org/avl/studymaterials/rcil-africa/2016/book3_6.pdf $>$ 
227. Vienna Convention on the Representation of States in their Relations with International Organizations of a Universal Character, 1975, available at $<$ http://legal.un.org/ilc/texts/instruments/english/conventions/5_1_1975.pdf>

228. Special Representative on Mediation, available at $<$ https://www.oscepa.org/activities/special-representatives/mediation/specialrepresentative-on-mediation>

229. Decision No. 3/11 Elements of the Conflict Cycle, Related to Enhancing the OSCE's Capabilities in Early Warning, Early Action, Dialogue Facilitation and Mediation Support, and Post-Conflict Rehabilitation, MC.DEC/3/11, 7 December 2011, available at $<$ https: $/ /$ www.osce.org $/ \mathrm{mc} / 88635$ ?download $=$ true $>$

230. Convention on Conciliation and Arbitration within the OSCE, 15 December 1992, available at $<$ https://www.osce.org/cca/111409?download=true $>$

231. Helsinki Document: The Challenges of Change, Conference for Security and Co-operation in Europe, 9-10 July 1992, available at $<$ https://www.osce.org $/ \mathrm{mc} / 39530$ ?download=true $>$

232. OSCE, Arms control, available at $<\mathrm{http}$ //www.osce.org/arms-control $>$

233. OSCE, Mission to Serbia, available at $<$ https://www.osce.org/mission-toserbia>

234. OSCE, Mission to Moldova, available at $<$ https://www.osce.org/missionto-moldova>

235. OSCE Special Monitoring Mission to Ukraine, available at $<$ https://www.osce.org/special-monitoring-mission-to-ukraine>

236. OSCE Project Co-ordinator in Ukraine, available at $<$ https://www.osce.org/project-coordinator-in-ukraine>

237. Helsinki Document: The Challenges of Change, Conference for Security and Co-operation in Europe, 9-10 July 1992, available at $<$ https://www.osce.org $/ \mathrm{mc} / 39530$ ?download $=$ true $>$

238. OSCE, Countering terrorism, available at $<\mathrm{http}$ ://www.osce.org/countering-terrorism $>$

239. Ad Hoc Committee on Countering Terrorism, available at $<$ https://www.oscepa.org/activities/ad-hoc-committees-and-workinggroups/countering-terrorism/countering-terrorism?start=1>

240. Helsinki Document: The Challenges of Change, Conference for Security and Co-operation in Europe, 9-10 July 1992, available at $<$ https://www.osce.org/mc/39530?download=true $>$

241. Decision No. 5/99 Forum for Security Co-operation (FSC), FSC.DEC/5/99, 6 October 1999, available at < https://www.osce.org/fsc/29839?download=true $>$ 
242. OSCE Handbook of Best Practices on Small Arms and Light Weapons, available at $<$ https://www.osce.org/fsc/13616?download=true $>$

243. OSCE Rules of Procedure, MC.DOC/1/06, 1 November 2006, available at $<$ https://www.osce.org/mc/22775?download=true $>$

244. Special Representative on Anti-Semitism, Racism and Intolerance, available at $<$ https://www.oscepa.org/activities/special-representatives/anti-semitismracism-and-intolerance $>$

245. Special Representative on Gender Issues, available at $<$ https://www.oscepa.org/activities/special-representatives/gender-issues $>$

246. OSCE, Country visits, available at $<$ https://www.osce.org/secretariat/107218>

247. Special Representative on Mediterranean Affairs, available at $<$ https://www.oscepa.org/activities/special-representatives/mediterraneanaffairs/special-representative-for-mediterranean-affairs>

248. Special Representative on Central Asia, available at $<$ https://www.oscepa.org/activities/special-representatives/central-asia/specialrepresentative-on-central-asia>

249. Special Representative on South East Europe, available at $<$ https://www.oscepa.org/activities/special-representatives/south-east-europe/specialrepresentative-on-south-east-europe $>$

250. Security Sector Governance and Reform: Guidelines for OSCE Staff, 1 April 2016, available at $<\mathrm{https} / / / \mathrm{www}$.osce.org/secretariat/231176?download=true $>$

251. Молдован В. В., Кацавець Р. С. Юридична клініка: навч. посібник. Київ: Центр учб. літератури, 2007. 224 с. URL: (дата звернення: 31.05.2021). URL: http://library.nlu.edu.ua/POLN_TEXT/CUL/50-Uridichna_klinika-Moldovan.pdf (дата звернення: 31.05.2021).

252. Доброхотова Е. Н. Практическое обучение юристов в России : история становления и перспективы развития (на примере Юридической клиники в СПбГУ) : дисс. ... канд. юрид. наук : 12.00.01. СПб., 2007. 196 с. URL: http://www.dslib.net/teoria-prava/prakticheskoe-obuchenie-juristov-v-rossii-istorijastanovlenija-i-perspektivy-razvitija.html (дата звернення: 31.05.2021).

253. Фігель Ю. О. Роль юридичних клінік у формуванні вмінь реалізації права студентами юридичних спеціальностей: дис. ... канд. юрид. наук: 12.00.01. Львів, 2011. 198 с. $\quad$ URL: http://194.44.11.130/cgibin/irbis_nbuv/cgiirbis_64.exe?Z21ID $=\& I 21 \mathrm{DBN}=\mathrm{EC} \& \mathrm{P} 21 \mathrm{DBN}=\mathrm{EC} \& \mathrm{~S} 21 \mathrm{STN}=1 \&$ $\mathrm{S} 21 \mathrm{REF}=10 \& \mathrm{~S} 21 \mathrm{FMT}=$ fullwebr $\& \mathrm{C} 21 \mathrm{COM}=\mathrm{S} \& \mathrm{~S} 21 \mathrm{CNR}=20 \& \mathrm{~S} 21 \mathrm{P} 01=0 \& \mathrm{~S} 21 \mathrm{P} 02$ $=0 \& \mathrm{~S} 21 \mathrm{P} 03=\mathrm{A}=\& \mathrm{~S} 21 \mathrm{COLORTERMS}=1 \& \mathrm{~S} 21 \mathrm{STR}=\% \mathrm{D} 0 \% \mathrm{~A} 4 \% \mathrm{D} 1 \% 96 \% \mathrm{D} 0 \% \mathrm{~B} 3$ \%D0\%B5\%D0\%BB\%D1\%8C\%20\%D0\%AE\$ (дата звернення: 31.05.2021). 
254. Стандарти юридичних клінік України від 16.11.2003 p. (із змін. та допов. від 25.08.2005 р.) : Асоціація юридичних клінік України [Електронний pecypc]. - Режим доступу: http://pravo.prostir.ua/library/412.html (дата звернення: 31.05.2021).

255. Положення про юридичну клініку «Істина» Дніпропетровського державного університету внутрішніх справ: наказ ректора від 27.04.2017 № 295 . Дніпро: Видавництво ДДУВС.

256. Галай А. О. Юридична клініка як суб'єкт адміністративних правовідносин. Бюлетень Міністерства юстиції України. 2013. № 4 (138). С. 66 73. URL: http://nbuv.gov.ua/UJRN/bmju_2013_4_12 (дата звернення: 31.05.2021).

257. Концепція розвитку юридичної освіти. URL: https://mon.gov.ua/ua/osvita/visha-osvita/koncepciya-vdoskonalennya-pravnichoyiyuridichnoyi-osviti-dlya-fahovoyi-pidgotovki-pravnika (дата звернення: 31.05.2021).

258. Галай А. О., Іваніщ Я. В. Педагогічна характеристика юридичної клінічної освіти. Вісник Асоціації юридичних клінік України. 2005. № 2. С. 2 - 3. URL: https://scholar.google.com.ua/citations?user=WBp0hY0AAAAJ\&hl=uk (дата звернення: 31.05.2021).

259. Савелова Ю. М. Поняття «юридичної клінічної освіти» в Україні. Актуальна юриспруденція: матеріали наук.практ. інтернет-конференції (05 березня 2013 p.). URL: https://legalactivity.com.ua/index.php?option $=$ com_content\&view $=$ article \&id $=488 \%$ 3A060313-06\&catid=60\%3A1-0313\&Itemid=75\&lang=ru 31.05.2021).

260. Журавський В. Підвищення рівня науково-методичного забезпечення вищої юридичної освіти - шлях до европейської спільноти. Юридический вестник. 2003. № 4. С. $98-104$.

261. Журавський В., Копиленко О. Юридична освіта в України: сучасний стан та напрями вдосконалення. Право України: Юрид. журн. 2004. № 11. С. 3 13.

262. Лоджук М.Т. Юридичні клініки в Україні: освіта та правова допомога : монографія. Одеса: Фенікс, 2015. 328 с.

263. Правнича клінічна освіта в Україні: навч. посібник. / заг. ред. В. М. Сущенка. Київ: Ваіте, 2020. 274 с. URL: https://egalclinics.in.ua/navchalnyjposibnyk-pravnycha-klinichna-osvita-v-ukrayini/ (дата звернення: 31.05.2021).

264. Комітет з питань освіти, науки та інновацій. 2020. Проект Концепції розвитку юридичної освіти. URL: http://kno.rada.gov.ua/news/main_news/75465.html (дата звернення: 31.05.2021). 